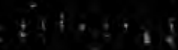
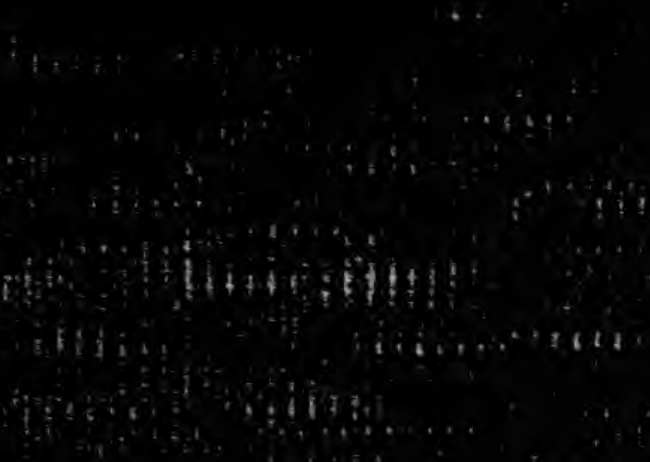

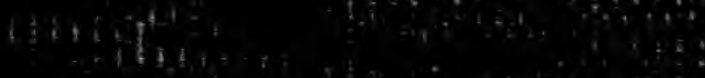

Pition initititis

$\therefore$ at

*

a $=$ in

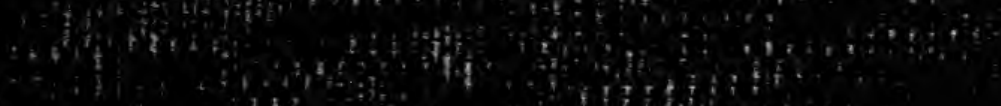

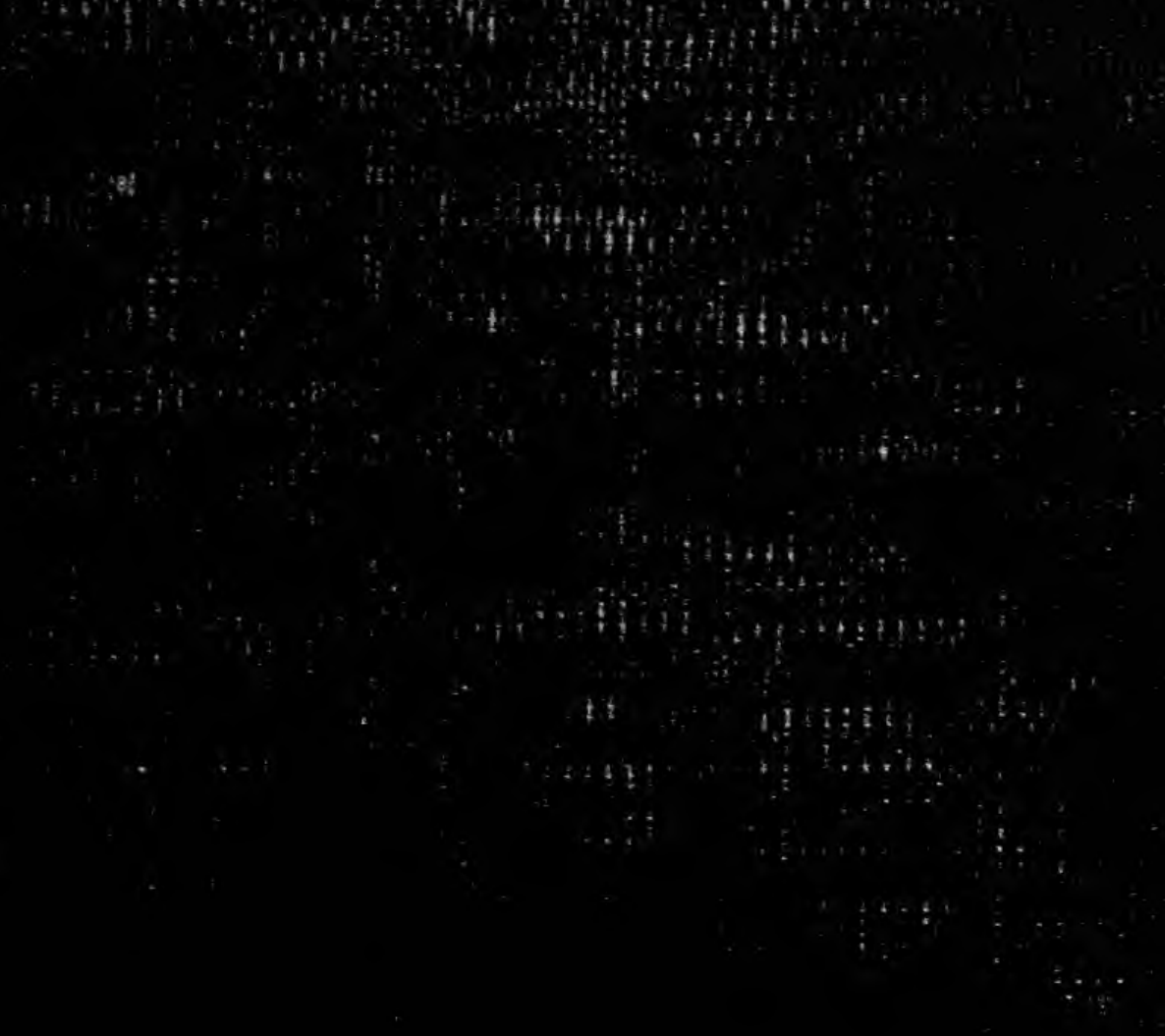



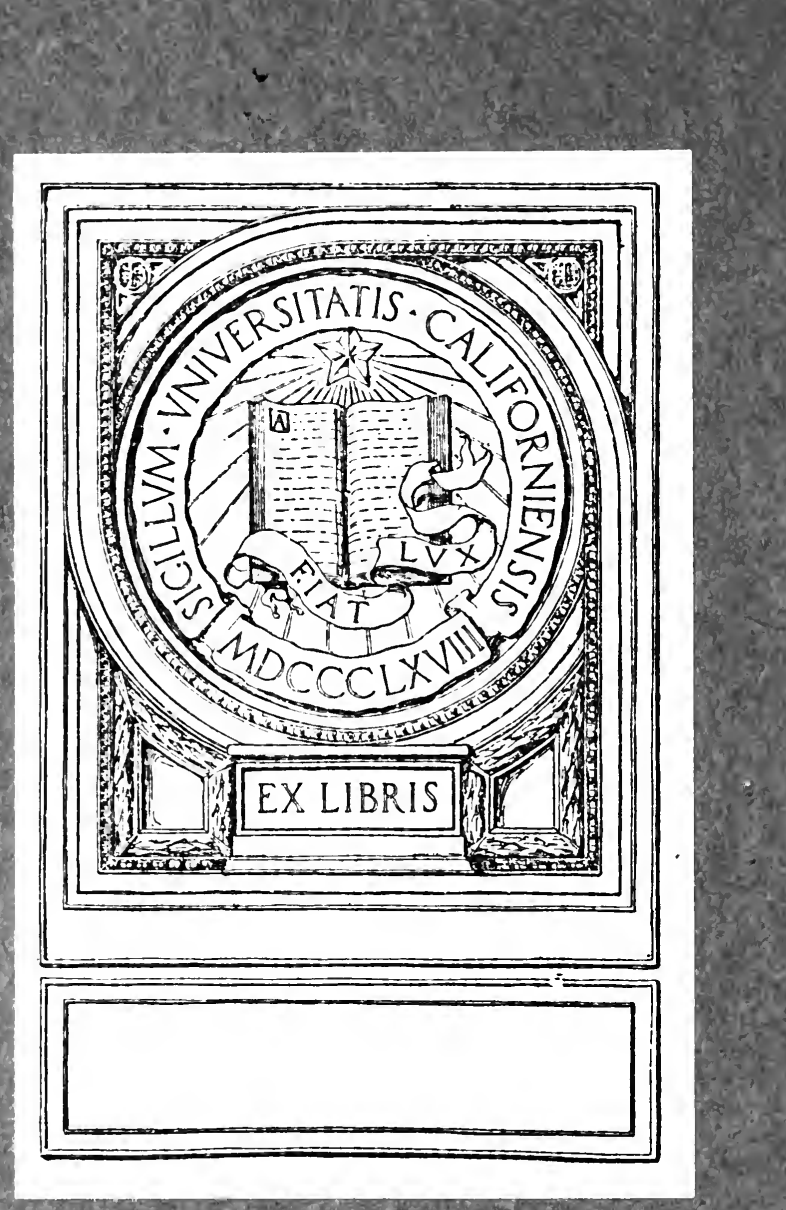



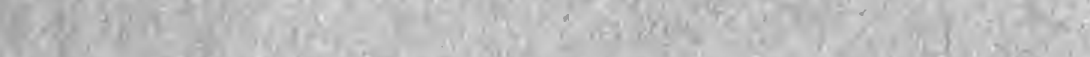

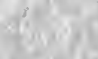

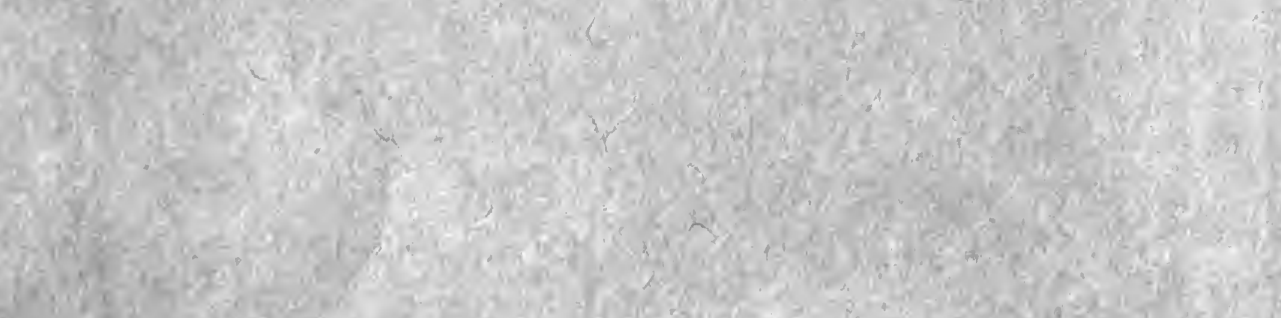

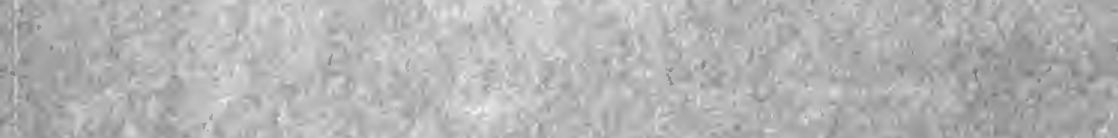
a

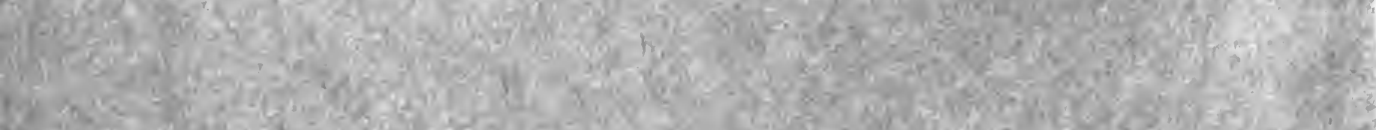
He

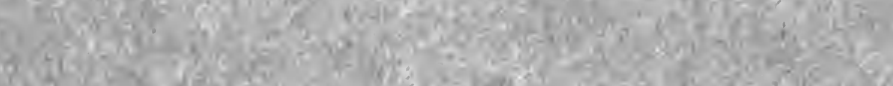
20 ento

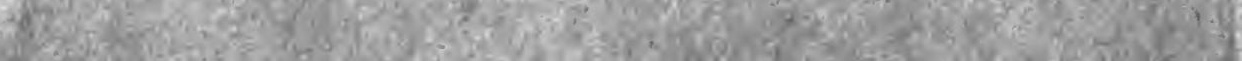



STUDIES IN HISTORY, ECONOMICS AND PUBLIC LAW EDITED BY THE FACULTY OF POLITICAL SCIENCE OF COLUMBIA UNIVERSITY

Volume XXIV]

[Number 3

\section{THE INTERNATIONAL POSITION}

OF

\section{JAPAN AS A GREAT POWER}

BY

SEIJI G.|HISHIDA, Ph.D.

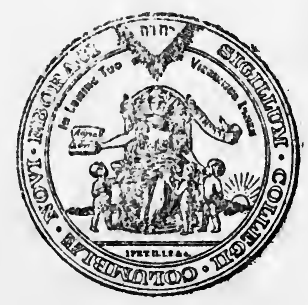

Wew Work

THE COLUMBIA UNIVERSITY PRESS

THE MACMILLAN COMPANY, AGENTS, LONDON: P. S. KING \& SON

1905 


\section{Cratumbia Eanuexsity}

\section{FACULTY OF POLITICAL SCIENCE}

Nicholas Murray Butler, LL.D., President. J. W. Burgess, LL.D., Professor of Political Science and Constitutional Law. Munroe Smith, LL.D., Professor of Roman Law and Comparative Jurisprudence. F. J. Goodnow, LL. D., Professor of Administrative Law and Municipal Science. E. R. A. Seligman, LL.D., Professor of Political Economy and Finance. H. L. Osgood, Ph.D., Professor of History. Wm.A. Dunning, LL.D., Professor of History and Political Philosophy. J. B. Moore, LL.D., Professor of International Law. F. H. Giddings, LL.D., Professor of Sociology. J. B. Clark, LL.D., Professor of Political Economy. J. H. Robinson,Ph.D., Professor of History. W. M. Sloane, L.H. D., Professor of History. H. R. Seager, Ph.D., Professor of Political Economy. H. L. Moore, Ph.D., Professor of Political Economy. W. R. Shepherd, Ph.D., Adjunct Professor of History. J. T. Shotwell, Ph.D., Adjunct Professor of History. G. W. Botsford, Ph.D., Adjunct Professor of History. V. G. Simkhovitch, Ph.D., Adjunct Professor of Economic History. E. T. Devine, LL.D., Professor of Social Economy. Henry Johnson, Ph.D., Professor of History. S. McC. Lindsay, Ph.D., Professor of Social Legislation. C. A. Beard, Adjunct Professor of Politics. Rudolf Leonhard, J.U.D., Kaiser Wilhelm Professor of German History and Institutions, I 907-08. G. J. Bayles, Ph.D., Lecturer in Ecclesiology.

\section{SCHEME OF INSTRUCTION}

\section{GROUP I. HISTORY AND POLITICAL PHILOSOPHY.}

Subject A. Ancient and Oriental History, nine courses. Subject B. Mediæval History, six courses. Subject C. Modern European History, eight courses. Subject D. American History, eleven courses. Subject E. Political Philosophy, three courses. Courses in church history given at the Union Seminary are open to the students of the School of Political Science.

\section{GROUP II. PUBLIC LAW AND COMPARATIVE JURISPRUDENCE.}

Subject A. Constitutional Law, four courses. Subject B. International Law four courses. Subject C. Administrative Law, seven courses. Subject D. Roman Law and Comparative Jurisprudence, seven courses. Courses in Law given in the Columbia Law School are open to the students of the School of Political Science.

\section{GROUP III. ECONOMICS AND SOCIAL SCIENCE.}

Subject A. Political Economy and Finance, twenty courses. Subject B. Sociology and Statistics, ten courses. Subject C. Social Economy, three courses. Courses in Economics and Social Economy given in the Schocl of Philanthropy are open to students in the School of Political Science.

Most of the courses consist chiefly of lectures; a smaller number take the form of research under the direction of a professor. In each subject is held at least one seminar for the training of candidates for the higher degrees. The degrees of A.M. and Ph.D. are given to students who fulfil the requirements prescribed by the University Council. (For particulars, see Columbia University Bulletins of Information, Faculty of Political Science.) Any person not a candidate for a degree may attend any of the courses at any time by payment of a proportional fee. Three or four University fellowships of $\$ 650$ each, the Schiff fellowship of $\$ 600$, the Curtis fellowship of $\$ 600$, the Garth fellowship in Political Economy of $\$ 650$, and University scholarships of \$I 50 each are awarded to applicants who give evidence of special fitness to pursue advanced studies. Several prizes of from $\$ 50$ to $\$ 250$ are awarded. The library contains over 400,000 volumes and students have access to other great collections in the city. 
THE INTERNATIONAL

\section{POSITION OF JAPAN}

AS A

GREAT POWER

BY

SEIJI G. HISHIDA. Ph.D.

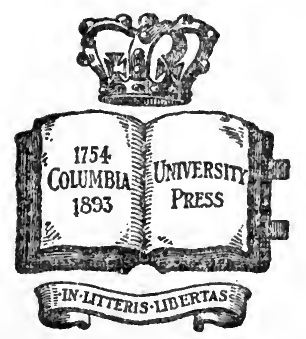


$L$

add'l. 
STUDIES IN HISTORY, ECONOMICS AND PUBLIC LAW EDITED BY THE FACULTY OF POLITICAL SCIENCE OF COLUMBIA UNIVERSITY

$$
\text { VOLUME XXIV-NO. } 3
$$





\section{PREFACE}

JAPAN, an Asiatic nation, which, until forty years ago, maintained for more than two centuries a policy of strict seclusion, is to-day not only admitted into the comity of civilized nations, but has, in matters concerning the Far East, come to play a part as important as that of any of the great powers of the West. The Island Empire, which ten years ago achieved an unbroken victory in a struggle with an eastern nation of four hundred million people, lately drifted into war with one of the strongest powers of Europe and has again won an "unbroken victory on land and sea." Does the "marvelous and swift progress" of modern Japan tend to become a "peril" to western civilization? Or does it contribute to the great work of the world's civilization? Will Japan use her power in obtaining exclusive privileges, or in leading toward the light her sister nations of Asia? Is she persona grata or persona non grata to the nations engaged in world-intercourse? Strongly believing that what has been accomplished by Japan in the interest of civilization is an earnest of what will be done hereafter, I have endeavored by careful research to trace Japan's historic policy in dealing with foreign nations. Incidentally frequent references have been made to the diplomatic and commercial history of Europe and America, to the principles of international and other public law, as well as to phases of private law, and to economics and sociology, in order to elucidate with scientific precision the relations between the East and the West. 
I gratefully acknowledge my indebtedness to the members of the Faculty of Political Science in Columbia University, and especially to Professor John Bassett Moore, under whose supervision this work was undertaken.

SeIJi G. Hishida.

New York City, September, 1905. 



\section{ERRATA}

Page 10, second line, read for " 1863 ," " 1868 ."

Page 22, footnote, read for "The Prince," "Il Principe."

Page 50, ninth line, read for "Tong," "Tang."

Page 57, eleventh line, read for "Heiau," "Heian."

Page 83, twenty-sixth line, read for "Koyoshima," "Kagoshima."

Page 90, fourth line in footnote, read for " 562 ," "502."

Page 91, twelfth line, read for "1554," "I 564 ."

Page 128, fourth line in footnote, for "S. Hozumi, op. cit." substitute "N. Hozumi, Ancestor Worship."

Page 148, first and third lines, read for "five," "eight."

Page 152, tenth line in footnotes, read for " 1889 ," " 1886 ."

Pages 165 and I88, read for "Tai-won-Kun," "Tai-Om-Kun."

Page 167 , footnote 2 refers to the words "coup d" état" in the twentyfirst line.

Page 168, twenty-second line, read for "in April," "on April I8."

Page I69, sixth line in footnotes, read for "rice," "grain."

Page 210, sixth line, read for "Chili," "Pechili."

Page 224, sixteenth line, add the words "and Korea" after the word "Manchuria."

Page 230, fourth line, read for "Ta-tung-kou," "Antung."

Page 285, seventh line, read for "Beneditti,". " Benedetti."

Page 285, twenty-first line, read for "New York, 1902," " 2 vols. London, 1883."

Page 285, thirty-fourth line, read for "Forster," "Foster."

Page 286, fifteenth and sixteenth lines, read for "Hall, W. A.," "Hall, W. E."

Page 286, nineteenth line, for "Harisse" read "Harrisse."

Page 287, ninth and tenth lines, add "J." after "T."

Page 289, sixth line, read for "Treaties," "Treaty." 


\section{CONTENTS}

\section{CHAPTER I}

INTRODUCTION

I. International Society and its Characteristics .........

2. International Politics in Europe-The Balance of Power . . . 16

3. International Politics in-America-The Monroe Doctrine . . . 33

4. Issue of International Politics in the Far East . . . . . . 38

\section{CHAPTER II}

INTERNATIONAL SOCIETY OF ANCIENT ASIA, 660 B. C.-930 A. D.

5. The Early Intercourse of Japan with the Korean Kingdoms and China ............... 4 40

6. Political Relations of Japan with the Korean Kingdoms and China ................ . 44

7. Internal Affairs of Ancient Japan .......... 52

\section{CHAPTER III}

DREAMS OF UNIVERSAL EMPIRE, 894-1595

8. The Activity of the Mongol Tartar . . . . . . . . 58

9. The Result of the Mongol Invasion-Period of Piracy . . . . 67

- ro. The Attempts of Taiko the Great to Subjugate China and Korea. 70

\section{CHAPTER IV}

THE FIRST INTERCOURSE OF JAPAN WITH THE EUROPEAN NATIONS,

$$
1541-1638
$$

II. With the Portuguese and the Spaniards . . . . . . . 79

12. With the Dutch and the English . . . . . . . . . 88

13. Diplomacy of the Tokugawa Shogunate ......... 96 24I] 
REOPENING OF THE SEALED JAPAN, I643-1863

I4. Attempts to Reopen the Empire by European Powers . . . I 104

15. American Mission to Reopen Japan, and Treaty Relations Occidental States............. 106

I6. Restoration of the Imperial Sovereignty . . . . . II8

\section{CHAPTER VI}

JAPAN'S ENTRY INTO THE COMITY OF NATIONS, I868-1899

17. Consular Jurisdiction and Tariff Questions under the Old

Treaties ................. I32

18. Revision of the Treaties and Present Treaty Relations ... . I37

\section{CHAPTER VII}

MODERN INTERNATIONAL RELATIONS OF JAPAN WITH ASIATIC NATIONS, I868-I 898

19. The First Treaty with China .......... I53

20. The Formosan Question (1874) . . . . . . . . . . 155

21. The Loochoo Complication . . . . . . . . . . . . 159

22. Japan's Policy to Open Korea to the World . . . . . . . . I63

23. The Chinese-Japanese War ............ I70

24. The Peace of Shimonoseki and the New Commercial Treaty with China .............. . . 176

25. Treaty Relations with Siam ........... I83

\section{CHAPTER VIII}

THE FAR EASTERN QUESTION, I895-1900

26. Russo-Japanese Rivalry in Korea .......... 185

27. Struggles of the Great Powers in China-Spheres of Interest . 194

\section{CHAPTER IX}

THE FAR EASTERN QUESTION, IQ00-1905

28. The Boxer Troubles of $1900 \ldots . . . . . . . .210$

29. The Manchurian Question ............ 217

30. The Anglo-Japanese Alliance ... . . . . . . . . 223

| 31. The Russo-Japanese Difierence . . . . . . . . . . 227 
32. The Peace of Portsmouth

33. The Status of Manchuria and Korea . . . . . . . . . . . . . . . 239

\section{CHAPTER $\mathrm{X}$}

\section{CONCLUSION}

34. Résumé. . . . . . . . . . . . . . . 251

35. The Mission of Japan . . . . . . . . . . . 258

\section{APPENDIX}

A. The Treaty of Portsmouth .... . . . . . . . . . 274

B. The Renewed Anglo-Japanese Alliance .......... . 282

Bibliography .................. . . 285 



\section{CHAPTER I}

\section{INTRODUCTION}

International Society and its Characteristics.-Although nations are, from the ethnographical, geographical and political viewpoints, divergently distributed over the earth, they yet have intercourse and compacts with one another. The intercourse of nations may be manifested in the establishment of diplomatic relations; in the pursuit of commerce, industry and navigation; in the cultivation of science, art and religion; in immigration, travel, intermarriage and social pleasures; in brief, in all the forms of activity which are necessary to satisfy the wants of mankind. In the conduct of intercourse a group of different nations exhibits "purposes of common concern," or, "consciousness of kind," and, therefore, forms a society, ${ }^{1}$ just as individuals create a private society, or citizens and ruler organize a municipal community or a national state. The society composed of different nations, or states, has been called. international society, the society of states, or the " family of nations," in which the associating members are bound together. The binding power of international society, even though it has a "common civilization," is necessarily weaker and looser than that of the municipal society, in so far as the former consists of members having conflicting traditions and histories differing in their details. The "consciousness of kind" in international society is im-

${ }^{1}$ As to the conception of a society, see Giddings, The Principles of Sociology, pp. 3-5 and 17-18. 
perfect. The perfection of international life still belongs to the future of civilization. Compared with the individual society, like the club or the union, international society, however, is more exclusive and indispensable. No nation is permitted to remain in isolation, ${ }^{1}$ while a disgruntled member may voluntarily withdraw from his club or a recalcitrant member may be compulsorily expelled. The western nations, by the exercise and the display of force, established diplomatic and commercial relations with China and Japan in the middle of the last century. In 1876 Japan took the initiative in opening the "Hermit Kingdom" of Korea, not by the exercise of direct force, but by a show of naval power.

Ubi societas $i b i$ jus est. As the national state administers its justice and peace by municipal law, so international society regulates its intercourse according to international law. Society, whether national or international, must have power to enforce the law, for without it social order would be replaced by anarchy on land and by piracy on the high seas. The power to compel obedience and punish disobedience is, or originates in, sovereignty. The object of sovereignty is identical both in the national and in international society. Its application is, however, somewhat different. Sovereignty, from the standpoint of constitutional law, is original, unlimited, universal power over the subject members of the state. ${ }^{2}$ In the sense of international law, sovereignty is the independent power of each state in the management of its foreign intercourse, as opposed to the will of all other states, $i$. $e$. it consists in the independence of one

1 Westlake, International Lazv, pp. 6-7.

2 Burgess, Political Science and Comparative Constitutional Law, vol. i, p. 52. Hozumi, Ken-po-Tai (Outline of the Japanese Constitution), pp. 3, II. Laband, Das Staatsrecht des deutschen Reichs (edition of 1902), p. I3. 
member in relation to the other members. ${ }^{1}$ The modern international society, consisting of independent nations, does not recognize any universal and absolute power, like the universal rule of Rome. Modern international law is not a universal law under a common superior, like the jus gentium $^{2}$ of Rome, but is a system of rules for the guidance of independent states in their mutual intercourse. It declares that every independent state has the right to do whatever is necessary for its existence and welfare by all legitimate means, "such as the pacific acquisition of new territory, the discovery and settlement of new countries, the extension of its navigation and fisheries, the improvement of its revenues, arts, agriculture and commerce, the increase of its military and naval force." 3 On the other hand, an independent state is bound to respect these rights in other states. ${ }^{4}$ All sovereign states are, in the eye of international law, equally entitled to claim such rights and equally bound to perform such duties.

Speaking historically, the principle of the equality of sovereign states has not been fully enforced in cases where an aggressive state infringed the sovereign rights of a feeble state. International society, composed of independent sovereign states, could not establish a "common superior" or universal sovereign which might theoretically administer international justice. On the contrary, it has been left to independent states to interpret and execute in-

1 As to the distinction between internal and external sovereignty, see Wheaton, Elements of International Law, part i, chap. ii, par. 5. Heffter, Völkerrecht (6th edition), p. 40. Meyer, Deutsches Staatsrecht (edition of 1878), p. Io. Holland, Jurisprudence (9th edition), p. 47.

2 The "jus gentium was not law international, but law universal." Walker, The Science of International Law, p. 62.

8 Wheaton, Elements of International Law, part ii, ohap. i, par. 4.

4 Hall, International Law (4th edition), p. 45. 
ternational law by themselves, separately or corporately. Under such circumstances, an aggressive state would assert its selfishness at the expense of a weaker state. The members of the international society, however, have not been so indulgent as to give a free hand to the aggressor. When the occasion arises, certain states, called the "great powers," 1 exercise their influence in international politics for the general interests of international society without violating the legal equality of the weaker states. They have not hesitated even to undertake intervention in affairs belonging purely to a third state. The exercise of influence by a single power is the system that now prevails on the American continents under the name of the "Monroe doctrine;" but combined interference has been the system of Europe, and it is to-day the characteristic of the conduct of the powers interested in the Far East, its predominating feature being the maintenance of the "balance of power."

International Politics in Europe-The "Balance of Power." - To understand concretely modern international life, it is not without profit to recur to the political relations of ancient Greece. Each commonwealth ( $\pi \delta \lambda_{\iota s}$ ) of ancient Greece, though it may have occupied but a little island, valley, town or peninsula, possessed an independent power (aviovouia), with the right of making war and peace, as does the modern independent state. In their international life

${ }^{1}$ For the influence of the great powers, see Lawrence, Essays on Some Disputed Questions in Modern International Law, essay v, "Primacy of the Great Powers." Westlake, International Laze, p. 92 et seq. "The Political Inequality of States and the Great Powers of Europe." Rivier, Principes $d u$ droit des gens, vol. i, pp. 125-126. See also "The Primacy of the United States in America," Lawrence, International Law, par. I36. The German authorities, Liszt and Zorn, say Japan entered the ranks of the great powers in 1894. See Völkcrrecht, p. 54; Grundzüge des Völkerrechts, p. 21. 
these petty Hellenic city-states had a very simple and imperfect body of rules developed from their philosophy, religion and custom. ${ }^{1} \quad$ Athens, Sparta, Thebes and Macedon assumed leadership (irysovía) in the political struggle-in commercial, territorial and colonial development-as do the modern great powers. The principle of the balance of power against an aggressive member or foreign foe was intelligently applied for their self-preservation. ${ }^{2}$ Nevertheless, the Greeks, as the result of their strong but narrow communal spirit, ${ }^{3}$ in time became weak against external attack, and the possibility of their higher development in international life was destroyed in 338 в. С., when they were overwhelmed by the universal empire of Alexander the Great.

The primitive conception of the Roman state-kingdom or republic - was, like the Greek, that of a city-state (civitas). Though the Roman city-states each maintained an independent existence, there was less trace of true international law." This was, doubtless, owing to the political genius of the Romans, which was not based upon the principle of mutual respect among different nations, but sought to organize all mankind as the unit of state. ${ }^{5}$ Rome, under the Caesars, struggled for universal empire over her fellow states and foreign nations. The national code ( $j u s$ civile) was supplemented by the jus gentium-universal code; and the Roman imperium became imperium

1 For the law of peace and 'war of ancient Greece, see Walker's History of the Law of Nations, pp. 37-43.

2 See "Theory of the Balance of Power among the Ancient Nations," Wheaton, History of the Law of Nations, p. I6 et seq.

3 Burgess, Comparative Constitutional Law, vol. i, p. $3 \mathbf{I}$.

4 An account of the early international usages of the Romans may be found in Walker, History of the Law of Nations, pp. 44 et seq.

5 Burgess, op. cit., vol. i, p. 35. The political genius of the Roman. 
mundi. ${ }^{1}$ Under the Roman régime, the so-called international law, which regulated intercourse among different nations, was positive law in the strict Austinian sense, for it was based upon the command of a common superior. The universal sovereignty of a world clominion would have solved, at least temporarily, the question of world politicsthe conflict between nations.

But European nations had not as yet sufficiently developed to be ready for government by Roman universalism. Nations must have universal customs, a world language, $i$. e. universal consciousness of right and wrong, before the establishment of universal empire can take place; otherwise universalism checks the freedom of the individual, suppresses local autonomy, national traditions and patriotism; and the reaction against it destroys the stability of the universal empire. ${ }^{2}$ It is no wonder, then, that the Roman empire was at last destroyed, in $476 \mathrm{~A}$. D., by those Teutonic tribes whose political psychology involved national freedom, ${ }^{3}$ and that the latter constructed their states out of Roman provinces.

In the course of time, however, Teutonic rulers, combining with Roman bishops, founded a universal dominion, after the Roman fashion, and called it the "Holy Roman Empire." It was first established by the Frankish monarch, Charlemagne, in 800, and, after the coronation of Otto I, at Rome, in 962, Romano-German emperors claimed the powers of the Empire. ${ }^{4}$ The universalism of the Middle Ages was based upon the politico-religious principle. All nations were regarded as "one religious and political

1 Bluntschli, The Theory of the State, p. 38.

2 As to the vices of universalism, see Burgess, op. cit., vol. i, p. 36.

${ }^{3}$ For the political genius of the Teutonic race, cf. ibid., pp. 37-39.

$\checkmark$ Bryce, Holy Roman Empire, chaps. iv, v, viii. 
brotherhood, of which the Roman bishop was the spiritual head, and of which the Emperor was the secular chief." Emperor and Pope again made a mistake in their conception of universal peace. They saw only superficially the human race as a unit, but did not seriously consider that, in spite of this general unity, nations are individually different at heart.

While Emperor and Pope claimed world-wide dominion, the Teutonic race, which already had scattered all over Europe, was restlessly pursuing its political mission-to establish "states upon the principle of national union and independence." Though the kings of England, Denmark and Spain formally acknowledged the supreme power of the Holy Roman Empire of Charlemagne, theirs were in fact independent states. Since the treaty of Verdun (834), the Frankish Empire had broken into a number of kingdoms. France also broke away from the Empire in 888. The Holy Roman Empire was restored by Otto the Great in 962 , but it covered only the German-Italian nations. In the great struggle between the Emperor and the Pope in the eleventh century, the former was gradually stripped of his power. The feudal barons and free cities, taking advantage of the struggle, became more and more independent. After the proclamation of the constitution by the electoral diet at Frankfort in 1338 , the imperial office existed only at the pleasure of the feudal barons.

The power of the Pope, on the other hand, increased in proportion to the decline of the imperial power. The Pope came to claim the right "to give and take away empires, kingdoms, princedoms, marquisates, duchies, countships, and the possessions of all men." 1 The mighty effort of the

1 Cf. Gregory VII's letter to Emperor Henry IV in Bryce's Holy Roman Empire, chap. x, p. I6r. 
church to unite all Christendom against the Saracens in the Crusades, increased the papal power and influence. In the latter part of the Middle Ages his influence was universally recognized, and the Pope often acted as arbitrator between Catholic nations. ${ }^{1}$ A Papal Bull fixed the boundary line in the Portuguese-Spanish dispute in the fifteenth century.

As the universalism of the Emperor and the Pope declined, and nationalism, or the territorial sovereignty of independent states, increased in proportion, a marked change took place in the affairs of Europe. The Houses of Hapsburg of Austria, and of Valois of France, grew up gradually to be powerful dynasties. German and Italian principalities lying between them were exposed to the dynastic ambition of two great powers. Charles VIII of France, in 1495, invaded Naples and set up the power of France in Italy. His conquest created general alarm in Europe. Spain, the Emperor of Germany, the Pope, Milan and Venice, on March 3I, formed a league ${ }^{2}$ to compel Charles to abandon Naples. The league was renewed in the following year with the fundamental aim of the mutual preservation of the several states against the aggressive designs of any state. The modern European concert, or balance of power, may be traced back to this league, so far as combined interference against an aggressive state is concerned. ${ }^{3}$

The House of Hapsburg had, however, since the beginning of the sixteenth century, begun to threaten the rest of Europe. Charles I of Spain, the grandson of Maximilian of Austria, was elected to the German imperial throne in I5I9, as Charles V. This accession united the Austrian

1 Moore, International Arbitrations, vol. v, pp. 4825 et seq.

2 For the account of the invasion and the league, see Dyer, History of Modern Europe, pp. 212-219.

3 Wheaton, History of the Law of Nations, p. 80. 
dominions, the German Empire and all the Spanish possessions, including the vast colonial empire in America, so that Charles was the most powerful ruler in Christendom. Francis I of France, the rival of the Hapsburgs for supremacy in European politics, professed, of course, an open opposition to Charles. England entered into the vortex of continental politics under Henry VIII, who was intelligently guided by the famous Wolsey. Both Charles and Francis sought the alliance of England. When Francis threatened the Italian states, a defensive league ${ }^{1}$ was concluded against him by Charles V, England, the Pope and the Italian lords; but, when Francis had been restrained and Charles became aggressive, England, the Pope, Francis and the Italian principalities formed the Holy League of Cognac against Charles. $^{2}$ The dynastic struggles between the two great powers during the sixteenth century were much complicated by the Reformation. France, in spite of her cruel persecution of Protestants in her own dominions, endeavored to form an alliance with the Protestant states of Germany, with Sweden and Denmark, and even with heathen Turkey, against Charles V. After the death of Charles his dominions were divided between Philip II of Spain and Ferdinand of Austria. Both these successors of Charles were constantly engaged in religious and political activities. Philip soon dismembered Portugal, made the Netherlands his battle-ground for tyrannical oppression, and threatened the reduction of England to a Spanish province. But the Armada was destroyed, while the Hapsburg power in the Spanish dominions was broken by the resistance of the Dutch, assisted by Henry IV of France. In the beginning

1 For the league against Francis, see Johnson, Europe in the Sixteenth Century, p. 164 .

2 For the league against Charles, see ibid., p. I84. 
of the seventeenth century the religious aggressions of the Austrian Hapsburg kindled a general alarm in the Protestant states. Then it was that the king of France, guided by the celebrated Richelieu, and Gustavus Adolphus of Sweden, combined with the Protestant states of Germany and entered into the prolonged struggle against Ferdinand of Austria.

The old notion of universalism, or of a common superior - Pope and Emperor-gradually disappeared and finally received its death-blow through the Reformation and through the development of the idea of territorial sovereignty, which was derived from the feudal régime. The theory of nationalism was inculcated in Europe by Machiavelli. ${ }^{1}$ The bloody struggle of the Thirty Years' War was nothing but the effort of the individual state to maintain its sovereign rights against the religious and political interference of the Catholic rulers. From that time on the national state in Europe became predominant. The beginning of the era of independent states marks the beginning of that international society, the members of which are bound by ties of mutual respect. Had the individual states been left to themselves without the restraint of law-positive or customary-the world would have been controlled by military anarchy. Shocked by the brutal struggles of the sixteenth and seventeenth centuries, and especially by the horrible excesses of the Thirty Years' War, Grotius, ${ }^{2}$ the great Dutch jurist, propounded the theory that the intercourse of independent states should be regulated on the basis of absolute legal equality without the intervention of any common superior. Weary of the anarchical struggle of the Thirty

1 The Prince, published in 1522.

2 His celebrated book De Jure Belli ac Pacis was published in 1625 . For his influence upon the evolution of international law, see Lawrence, Essay on Modern International Law, essay iv. 
Years' War, European nations eagerly accepted the doctrine of Grotius. The Peace of Westphalia, signed in 1648 at Münster and Osnabruck, was the immediate fruit of the work of this great jurist. It recognized the independence of each separate state, even within the boundaries of the Holy Roman Empire. ${ }^{1}$ The principle of territorial sovereignty and the right of intercourse with any and every nation were generally and formally asserted by every independent state, both Catholic and Protestant, both great and small. The custom of maintaining permanent embassies, which had prevailed among the Italian states since the thirteenth century, ${ }^{2}$ now became the general practice of independent states. Thus the "family of nations" and international law came into existence in their more definite forms.

The doctrine of Grotius-the principle of the legal equality of sovereign states-was enlarged and emphasized by his followers. International transactions, however, in some cases, could not be settled on the basis of the legal equality of the parties concerned, since a strong state, having more power and influence than a weak one, naturally would be disposed to claim more than its due. Under the régime of that international law which recognizes no common superior, there was no remedy in such cases other than the "league," "alliance" "coalition" or "co-operation" of a number of states against the aggressive power. The system of the "balance of power," which had been initiated in the dark ages, was still useful, and indeed necessary, even in the enlightened era of international society.

1 Professor Westlake treats the effects of the Peace of Westphalia in the most accurate manner, in his International Law, chap. iv.

2 For the historical development of permanent embassies, see Nys, Les Origines du droit international, chap. xiv, pp. 297 et seq. Cf. Westlake, International Law, p. 59. 
By the remarkable success of her diplomacy at the Peace of Westphalia and the Peace of the Pyrenees, France put an end to the Spanish supremacy and secured for herself the highest position in Europe. Louis XIV, during the half century preceding I7I3, was the object of general fear throughout Europe. Against the undue claims of Louis upon the Low Countries, claims which threatened the existence of the United Provinces of the Netherlands, the "Triple League" " of the United Provinces, England and Sweden was formed in r668. The crafty Louis cleverly broke down the Triple Alliance and secured the secret assistance of England, which was then carrying on hostilities against the Dutch in a struggle for commercial supremacy. The Dutch, being now at enmity with two great maritime powers, formed a new league ${ }^{2}$ with Spain and Austria in I673 against Louis, and barely escaped dismemberment. As the result of the marriage of William of Orange and Princess Mary of York, in 1677, England and the United Provinces formed a personal alliance against France. Louis, notwithstanding the persecution of his Protestant subjects at home, provoked the Protestants of Hungary against the emperor of Austria, and, as Francis I had done, allied himself even with heathen Turkey to gratify his political ambition. In consequence, in 1686 the "great League of Augsburg" 3 was directed against him. Louis once more attempted the dismemberment of the Netherlands, but was thwarted by the "Grand Alliance" "and compelled to agree to the Peace

1 General Collection of Treaties (2d edition, London, 1712), vol. i, pp. $136-145$.

2 Dyer, History of Modern Europe, vol. iii, p. 369.

3 Ibid., vol. iii, p. 4 I9.

4 Originally an offensive and defensive alliance between Holland and Austria, into which England entered in December, 1689. General Collection of Treaties, vol. i, pp. 275-280. 
of Ryswick in I697. When Charles II of Spain died without issue, Louis claimed the Spanish succession for his grandson, Philip, by virtue of the will left by the king. To unite the Spanish dominions, which were still extensive, with France, would have destroyed the balance of the European system. Therefore, the second "Grand Alliance " ${ }^{1}$ between England, Austria and the Netherlands, was formed in I7OI against Louis. The so-called war of the Spanish succession went on until the Peace of Utrecht was concluded in I7I3-I4. In spite of the aggressive efforts of Louis XIV, France made little change in the system founded by the Peace of Westphalia, other than slight territorial adjustments of the frontiers. Her recompense was, on the other hand, "the disturbance of her finances, the exhaustion of her population and loss of her colonies abroad."

In the eighteenth century Sweden, which had since the time of Gustavus Adolphus signally exerted its influence upon the balance of power of Europe, and the Spanish monarchy, which had been a terrifying object for centuries, were reduced to the position of second-rate powers. Two new powers came to play an active part in European politics. Russia, gradually becoming a great power, began to expand at the expense of her neighbors. The second power was Prussia. The artificial expansion of its boundary towards Austria and Poland formed the main parts of its history in the eighteenth century. Having destroyed the maritime supremacy of Spain and France, England had become the dominating power in matters of colonial and commercial policy. But, although neither Russia nor Prussia nor England could rival the predominance held by Spain in the sixteenth century and by France in the seventeenth, the check-mate of the "league" was often invoked for the pre-

1 General Collection of Treaties, vol. i, pp. 415-421. 
servation of the status quo of the European system. The Triple Alliance between England, France and the Netherlands was formed in I7I7, partly against the aggressive activity of Russia, under Peter the Great, toward the Baltic Sea. ${ }^{1}$ This alliance, joined in the following year by Austria, was applied to the south of Europe when Philip V of Spain conquered Sardinia and was about to invade Sicily. ${ }^{2}$

The Peace of Utrecht by confirming England's possession of Gibraltar as well as by the advantages which she had wrested from France and Spain in the New World, greatly strengthened her position as a commercial and colonizing power. Her maritime supremacy, however, called forth the bitter opposition of France and Spain. The coalition of these Latin powers against England was the natural result. This Anglo-Latin struggle became entangled with the affairs of Austria and Prussia in the wars which then raged in continental Europe. When Frederick the Great made an undue claim upon Silesia and war broke out in 1745 between Austria and Prussia, England together with the Netherlands and Sardinia helped Maria Theresa while France and Spain supported her enemy. ${ }^{3}$ Although peace was nominally concluded at Aix-la-Chapelle in I748, another war broke out again between Prussia and Austria in 1756 , involving most of the European powers. Now things turned about. France took the side of Austria, with Russia; and even "Sweden, Denmark and Saxony were to be induced to join the alliance." " These continental powers were so jealous of the ascendency of Frederick that they suggested the dismemberment of Prussia. England under Pitt, however, joined Prussia, by paying a

1 Hassall, The Balance of Power (1715-1789), pp. 42, 46.

2 Ibid., p. 54. $\quad{ }^{3}$ Freeman, General Sketch of History, p. 307.

4 Hassall, The Balance of Power, pp. 243-245. 
subsidy of $£ 670,000$ a year to the king of the isolated power. ${ }^{1}$ Spain at first maintained neutrality, but in $176 \mathrm{I}$ entered into hostilities against the Anglo-Prussian alliance by the pacte de famille, ${ }^{2}$ an alliance with France. Hostilities were carried on on both sides of the Atlantic until peace was concluded at Paris and Hubertsburg in 1763 . But the Anglo-Latin colonial struggle did not cease with the Seven Years' War, for France and Spain had lost extensive possessions in the New World by the Treaty of Paris. When the war broke out between Great Britain and her American colonies, France entered into a coalition ${ }^{3}$ with the latter, and still later Spain took part in the war against Great Britain. The British colonies secured their independence, but France and Spain, although they were to a certain extent victorious, were unable to recover their ancient prestige.

Russia under Catherine II revived her expansionist movement, in the course of which Poland, Turkey and Sweden were the natural sufferers. As to Poland, Catherine stepped in as early as 1764 to interfere in its political affairs, taking advantage of the existing political corruption. Russian activity in Poland produced fear and jealousy in Prussia and Austria. Frederick the Great, a military diplomat, seeing the danger of the absorption of Poland by a single power, persuaded Austria to secure a part of the spoils and suggested the partition to Russia in order to maintain the balance among them. By the partitions of 1772 and 1793 , Poland was finally dismembered. Hitherto the system of the balance of power had been applied for the preservation of states. This was the first example of the misapplication

1 Hassall, The Balance of Power, pp. 252-253. 2 Ibid., p. 272.

${ }^{3}$ Moore, A Hundred Years of American Diplomacy (American Bar Association Report of 1900), p. 331. See foot-note for the treaty of alliance of the United States with France. 
of the system by the continental powers, to the destruction of an independent state. ${ }^{1}$

Catherine II perceived the difficulties arising out of the Russian eruption into the Baltic Sea, as shown by the prompt coalition of northern Europe under the lead of Great Britain, and inaugurated strenuous efforts to obtain an outlet on the Mediterranean through the Balkan peninsula. Russia had already established her influence on the northern coast of the Black Sea by the famous treaty of Kainardji with Turkey in $\mathrm{I} 774$, and Catherine was projecting a further expansion when she. made her celebrated journey into the Crimea. Joseph II of Austria foresaw that Catherine's activity in the peninsula would take the form of an attempt to absorb the Ottoman Empire, and suggested the partition of that empire. In 1787 Turkey entered into war with Russia and Austria. As soon as the existence of the empire was threatened, Pitt of England formed a triple alliance of England, Prussia and Holland against the aggressive designs of Russia and Austria. ${ }^{2}$ In the following year this alliance was also applied to northern Europe, when Russia attempted to annihilate Sweden with the assistance of Denmark. ${ }^{3}$

During the eighteenth century the sovereign rights of independent states were so little respected by aggressive powers that the dismemberment of weak states was attempted from time to time. But the latter were wisely relieved by the alliance headed by England. There was no significant change in the political system of Europe which had been arranged by the Peace of Westphalia, except the partition

1 Wheaton condemns this misapplication of the system of the balance of power which resulted in the dismemberment of an independent state. Cf. History of the Law of Nations, p. 280.

2 Hassall, The Balance of Power, pp. 385-6. $\quad 3$ Ibid., p. 384. 
of Poland. However, the selfish colonial policy of George III caused England to lose the vast dominion which was embraced in the United States.

At the end of the eighteenth century the French revolution broke out. Almost all the European states were involved in it; and the balance of power in Europe was again upset. Against the revolutionary and military aggressions of the revolutionary government of France, England formed a coalition ${ }^{1}$ with Austria, Russia, Prussia, Sardinia, Spain, Portugal and various minor states in I793. When Napoleon became the subject of universal alarm in Europe, Pitt again formed in 1805 a coalition ${ }^{2}$ composed of England, Russia, Austria and Sweden. Cleverly breaking into the English league, Napoleon established the " continental system," ${ }^{3}$ by which all continental states were to be brought under his influence and by which England was to be excluded commercially from the continent. But the exclusions and restrictions of continentalism eventually intensified the feeling against Napoleon on the continent. Russia first abandoned the policy, and other powers assumed one by one an attitude of hostility to the universalism of Napoleon. Finally, a coalition of the continental states, headed by Great Britain, overthrew Napoleon at Waterloo. The state system of Europe which was disturbed by revolutionary France and Napoleon, was restored by the Congresses of Paris and Vienna. ${ }^{4}$

European nations, warned by the world-wide wars of the

${ }^{1}$ Burrows, The History of the Foreign Policy of Great Britain, p. 187.

2 Ibid., p. 236.

3 Ibid., pp. 260 et seq. For a comprehensive treatment of the continental system, see Moore, International Arbitrations, pp. 4447 et seq.

4 For the Treaties of Paris and Vienna (I8I4-I8I5) which restored the European system, see Hertslet, The Map of Europe by Treaty, vol. i, pp. I et seq. and 60-295. 
seventeenth and eighteenth centuries and of the Napoleonic era, now sought universal peace. The so-called "concert of Europe" ${ }^{1}$ was established. Its principal object is to place certain questions of international concern under the superintendence of the great powers. It was the general interest of Europe to avoid the recurrence of universal war. The concert of Europe differed, however, from the socalled "Holy Alliance," which contemplated interference with the internal constitutions of independent states. As a matter of fact, the continental powers tried to attach the system of internal intervention to the concert of Europe, but in this they were thwarted by Great Britain. ${ }^{2}$ The members of the concert were Great Britain, France, Prussia, Austria and Russia, and later Italy, which was invited to join it in 1867 . The establishment of the independent states of Greece and Belgium; the erection of Egypt into a semi-sovereign state under the sovereignty of the Porte; the maintenance of the integrity of Turkey; the permanent neutralization of Switzerland, Belgium and Luxemburg, and the Suez Canal, have been the principal achievements of the great powers forming the concert of Europe.

The concert of Europe, however, is not applied to international affairs between the great powers themselves. None of the other great powers ventured to interfere in the Austro-Prussian War of 1866 or in the FrancoPrussian War of 1870; matters were left entirely to the parties themselves. ${ }^{3}$ Under such a régime, there is no guarantee for the avoidance of international conflicts among the great powers. But Prince Bismarck inaugurated the new plan for peace among the great powers in his doo-

${ }^{1}$ Lawrence, Essay on Modern International Law, pp. 210-216.

2 Ibid., pp. 217-223.

3 Ibid., p. 229. 
trine of "armed peace" with defensive alliance and progressive armament. Russia, in return for her benevolent neutrality during the Franco-Prussian War, expected Germany to support her views on the Eastern question. Russia had in fact taken advantage of the war to send a circular note to the great powers declaring herself to be no longer bound by the Black Sea clause of the Treaty of Paris of I856, which limited her armaments on the Black Sea. The Russian claim, though it was seriously condemned by England, was recognized in the London conference of $\mathrm{I} 87 \mathrm{I}$ through the valuable assistance of Bismarck. ${ }^{1}$ Seven years later, however, Bismarck refused to countenance the aggressive intent of the Treaty of San Stefano, and by the Berlin Congress in I 878 Russia was deprived of the fruits of her victory over Turkey. ${ }^{2}$ Russia then began to look for a new alliance. As Bismarck was much concerned over the possible alliance of Russia and France, who were both longing for an opportunity to revenge themselves upon Germany, he formed a defensive alliance with Austria in 1879 in order to provide for the emergency. ${ }^{3}$ In 1882 the alliance was joined by Italy, as the latter nation was threatened by the colonial activity of France in Northern Africa. ${ }^{4}$ In I 883 the Triple Alliance was formally constituted, its fundamental object being to insure the maintenance of the peace

1 Beneditti, Studies in Diplomacy, p. 96. See also Duggan, The Eastern Question, p. 129.

2 For the attitude of Bismarck toward Russia, see his Memoirs, chap. xxviii.

3 The text of the treaty is found in British and Foreign State Papers, vol. 73, p. 270. See also Beneditti, Studies in Diplomacy, pp. I20-121, and Debidour, Histoire diplomatique de l'Europe, vol. ii, conclusion i.

4 Beneditti, ibid., p. I35. Debidour says the Italian king Humbert had interviews with the German emperor and the Austro-Hungarian sovereign in 1882 , and in the following year the Italian government formally entered into the Austro-German alliance. See vol. ii, p. 543. 
of Europe. It must not be forgotten that Bismarck, after the formation of the Triple Alliance, made a secret treaty with Russia in order to keep "open the way to an entente cordiale" with that country, and to keep France isolated as far as possible. It remained nominally in force until Bismarck went out of office in $1890 .^{1}$

Though Bismarck so successfully tried to prevent Russia from joining with France, these countries came gradually to regard their alliance as a necessity to their interests in European politics. $^{2}$ In July, I890, a visit of the French fleet to Cronstadt gave to the world the first proof of the Dual Alliance. In October, I893, the appearance of the Russian fleet at Toulon demonstrated the existence of the alliance; the exchange of visits of president and czar during 1896 furnished a cordial sign of its continuance.

With the retirement of Beaconsfield from the British cabinet in I880, the foreign policy of Great Britain was somewhat changed by the peaceful Gladstone, who paid much attention to the Irish question and who endeavored to establish a good understanding with Russia and France. ${ }^{3}$ Ever since, the avoidance of continental entanglements has been the policy of England, although the Anglo-Russian friction on the Indian frontier, Anglo-French differences in Egypt and the Anglo-Italian understanding in the Mediterranean, have at one time and another caused or indicated a. favorable disposition on the part of Great Britain toward the Triple Alliance." Thus two alliances are now maintaining the balance of power among the great powers. The "concert of Europe" and the "armed peace" of the great powers are to-day insuring the

1 Phillips, Modern Europe, p. 533.

2 Debidour, Histoire diplomatique de l'Europe, vol. ii, conclusion vii.

? Ibid., vol. ii, conclusion ii.

4 Ibid., vol. ii, p. 559. 
peace of Europe. Except in minor matters, European questions are not at the moment occupying diplomatists. At the end of the nineteenth century, as the result of commercial and colonial expansion, the centre of the world-politics of Europe has shifted to the Far East.

International Politics in America-The Monroe Doctrine. -The character of American international politics is different from that of Europe. The balance of power, the concert of Europe, and the counterpoise of Triple and Dual alliances, represent principles almost unknown in the affairs of the western hemisphere. The thirteen American colonies secured their independence a century and a quarter ago by the aid of an alliance with France, and entered into the "family of nations." But their statesmen soon adopted the policy of " non-intervention" and " neutrality," in order to keep the New World out of Europe's " real or imaginary balances of power," and to prevent it from becoming implicated "by artificial ties in the ordinary vicissitudes of her politics." 1 The United States was, therefore, wisely conducted through the critical period of the general wars of Europe, growing out of the French Revolution, without being directly involved in them. After the Peace of Vienna of $\mathrm{I} \mathrm{I}_{5}$, the United States was for a while exempt from European menaces, but in the course of time new questions arose, which threatened to draw the American government into complications with Europe.

The czar of Russia, by a ukase issued in $182 \mathrm{I}$, claimed

1 For the policies of non-intervention and neutrality, see Professor J. B. Moore, A Hundred Years of American Diplomacy (Reports of American Bar Association, 1900), pp. 329, 334. Washington's neutrality proclamation of April 22, 1793, is found in Moore, International Arbitrations, vol. iv, p. 3968 . See also the Farewell Address of Washington and statements of John Adams and Jefferson in Wharton's International Law Digest, vol. i, pp. 172-173. 
exclusive sovereignty over the northwest coast of America from Bering's Straits down to the fifty-first degree of north latitude, and assumed to prohibit foreigners from carrying on commerce, navigation and fishery within a hundred Italian miles of the shore. ${ }^{1}$ While the United States was negotiating relative to the Russian claim, the "Holy Alliance" was contemplating the taking of steps to overthrow the republican governments of the Spanish-American states, whose independence had been duly recognized by the United States, and to restore them to their former position of Spanish dependencies. ${ }^{2}$ In order to defeat this aggressive design of the European powers, President Monroe declared in his message to Congress in 1823 , that any attempt on their part "to extend their system to any portion of this hemisphere" would be "dangerous to our peace and safety." Referring to the Russian claim, he said: "The American continents, by the free and independent condition which they have assumed and maintain, are henceforth not to be considered as subjects for future colonization by any European powers." These declarations constitute what has since been described as the "Monroe doctrine," which has become "a cardinal principle of American diplomacy." In its origin it was a defensive measure. Its principal objects were, first, to prevent the threatened intervention of the combined powers of Europe " for the purpose of reducing independent American states to subjugation to a European power" or destroying their republican institutions; second, to prevent European powers from founding colonies in the territory of

${ }^{1}$ Snow, Treaties and Topics in American Diplomacy, p. 27I. See also Moore, "The Monroe Doctrine," Political Science Quarterly, vol. xi, pp. 3-4.

2 Moore, ibid., p. II. George Canning, the British foreign secretary communicated the intention of the "Holy Alliance" to Mr. Rush, the American minister in London. 
those states. ${ }^{1}$ The upholding of these principles by the United States, on behalf of other American nations, is not a legal obligation, either in the sense of municipal law or in that of international law. The principle, as it was announced, did not call for legislative sanction, nor was the United States bound to maintain it by alliances, or to become the protector of any other nation by treaty stipulations. the contrary, the people of the United States were "left free to act, in any crisis, in such a manner as their feelings of friendship toward these republics and as their own honor and policy may at the time dictate." The Monroe doctrine is but a national policy of the United States-a conscious aspiration of her people.

The Monroe doctrine has been applied in various ways, and has been somewhat enlarged in its scope in later years. President Polk, during his administration, invoked the doctrine with reference to the possible intervention of European powers in consequence of the annexation of Texas, the Oregon boundary question, and the proposed military occupation of Yucatan by the United States. ${ }^{2} \mathrm{He}$ also expanded the doctrine, maintaining that a European power should not be permitted to acquire any new possession in the western hemisphere either by "purchase or conquest," which went beyond the original idea of Monroe. ${ }^{3}$ By the ClaytonBulwer treaty of 1850 , the United States secured from and gave to Great Britain a pledge not to " occupy, or fortify, or colonize, or assume or exercise any dominion over Nicaraugua, Costa Rica, the Mosquito Coast, or any part of

${ }^{1}$ Moore, "The Monroe Doctrine," Political Science Quarterly, vol. xi, p. 22.

${ }^{2}$ See the messages of President Polk to Congress, 1845 and 1848 .

8 Moore, ibid., p. 17. Professor Moore calls it the Polk doctrine instead of the Monroe doctrine. 
Central America." 1 The most striking application of the doctrine is to be found in the attitude of the United States towards the French occupation of Mexico with the design of replacing the native republican government with the monarchy of the European Maximilian. In this case Mr. Seward, who was then secretary of state, did not mention the Monroe doctrine by name, but it was in consequence of his representations, which were within the letter as well as the spirit of that doctrine, that France withdrew her troops from Mexico. ${ }^{2}$ When Venezuela was involved with Great Britain in the dispute as to the boundary of British Guiana, President Cleveland and Secretary Olney opposed the British territorial claim with the Monroe doctrine, and insisted upon Great Britain's recognizing it as a rule of American policy. Undoubtedly, the disputed boundary of an American nation with an adjacent European colony was not prima facie within the scope of the principle announced by Monroe, nor was his doctrine claimed by him to be a part of international law. ${ }^{3}$ The question as to the boundary of British Guiana was, however, subject to certain restrictions, eventually submitted to arbitration. When Venezuela was again menaced on account of debts and claims by certain European powers in I90I, President Roosevelt availed himself of the opportunity to set forth his views with regard to the Monroe doctrine. He clearly distinguished territorial from commercial questions. As to the former, he declared that "there must be no territorial aggrandizement by any non-American power at the expense of any American power on American soil." $\mathrm{He}$ added :

1 Article $\mathrm{i}$ of the Clayton-Bulwer treaty.

2 Henderson, American Diplomatic Questions, p. 405.

3 Professor Burgess points out the dangerous extension given to the Monroe doctrine by President Cleveland and Secretary Olney, in his article, "The Recent Pseudo-Monroeism," Political Science Quarterly, vol. xi. 
This doctrine has nothing to do with the commercial relations of any American power, save that it in truth allows each of them to form such as it desires. ... We do not guarantee any state against punishment if it misconducts itself, provided that punishment does not take the form of the acquisition of territory by any non-American power. ${ }^{1}$

In announcing his doctrine, President Monroe disclaimed any disposition on the part of the United States to interfere with the "existing colonies or dependencies of any European power;" his doctrine therefore was not designed to be inimical to the retention by European powers of their existing possessions in America. ${ }^{2}$ Nor was there any manifestation of a purpose to deny to the Latin-American states the right to settle questions among themselves. ${ }^{3}$ It seemed at one time as if the United States might intervene in the war between Chili and Peru, but those powers were eventually permitted to make peace without interference, as they did by the treaty of 1883 . The boundary quarrel between Chili and the Argentine Republic was finally settled by arbitration, and the two powers agreed to reduce their naval forces. ${ }^{4}$

The question of the Isthmian canal, which was in controversy between the United States and Great Britain for a halfcentury, has been definitely settled by the Hay-Pauncefote treaty concluded in I9or. By this treaty the permanent neutralization of the route is secured to all nations, as in the case of the Suez canal, while the United States possesses the right to construct the canal and to police it. ${ }^{5}$ The Cuban

1 President's Message, Dec., I90I.

${ }^{2}$ Hart, Foundations of American Foreign Policy, p. 2I5. ${ }^{3}$ Ibid.

4 See agreement between Chili and the Argentine Republic, concluded May 28, 1902. Foreign Relations of the United States, 1902, pp. 18 et seq.

5 The text of the Hay-Pauncefote treaty may be found ibid., pp. 518 et seq. See also Professor Moore's article upon the canal question, New York Times, March 4, Ig0o. 
question, which, by reason of unsettled conditions in the island, disturbed the United States for many years, was finally settled by the Spanish-American war of 1898 .

Whatever the divergences of opinion as to particular applications of the Monroe doctrine may have been, the United States has, during the past century, exercised, in the general interest of the New World, a powerful influence against European interference in the politics of the American continents; and the United States will continue to fulfill this mission with self-confidence and with the assent of the civilized world. ${ }^{1}$ President Roosevelt declared in his message to the Congress of I9OI, that the Monroe doctrine is " simply a step, and a long step, toward assuring the universal peace of the world by securing the possibility of permanent peace on this hemisphere."

is The peace of the western hemisphere is promoted by the leadership of the United States, and practically no important international question is raised by such leadership. But through her possession of the Philippine Islands and the enormous growth of her Asiatic commerce, the United States has been confronted, since the Spanish war, with the Far Eastern question.

Issue of International Politics in the Far East.-Asiatic nations, though they had, for many centuries, formed "a family of nations" with their own civilization, did not enter into treaty and diplomatic relations with Christian nations until the middle of the nineteenth century and did not become involved in the turmoil of world-politics with western powers until the Chino-Japanese War of 1894-95 was over.

1 The Hague Conference unanimously assented to the reservation by the delegates of the United States of "its traditional policy." Germany and Great Britain have ever since explicitly recognized the principle. See Moore, "Non-Intervention and the Monroe Doctrine," Harper's Monthly Magazine, Nov., 1904, pp. 867-868 and 869. See also Holls, The Peace Conferengf at the Hague, pp. 269 et seq. 
This war demonstrated to the world that China was corrupt and, left to herself, utterly defenceless. The great nations of the world, which had hitherto looked upon the immense population and the inexhaustible resources of China with something of awe, now became interested in the Celestial Empire, because of the apparent opportunity in that quarter for political and commercial expansion. The balance of power, the concert of the great powers, the " armed peace," and the Monroe doctrine secure the peace of Europe and America. Even in Africa and in Australasia the territorial and commercial situation has been practically settled. Asia is the only place in the world which is still at stake in international politics. The Far East becomes to-day the center of world-politics, in which Germany, Great Britain, France, Japan, Russia and the United States are concerned. The destinies of China and Korea, the peace of the Far East, and through that the peace of the world, depend upon decisions reached in Berlin, London, Paris, St. Petersburg, Tokio and Washington. As Japan is the only representative of the Asiatic races among these great powers, and as she has assimilated more of the western civilization than any other Asiatic race, her position in the future politics of the Far East will be of considerable importance and she cannot rid herself of the responsibility which this entails. What Japan has done in her dealings with other nations, is suggestive and instructive in judging whether she can effectively fulfill her responsibilities and whether she will be able to act conscientiously and harmoniously with the great powers of the -West for the perfection of that international society which is as yet composed of conflicting members-for the advancement of the world's civilization, not by monopolistic measures primarily designed for the aggrandizement of a single empire, but by active co-operation with all nations fitted for the civilizing mission. 


\section{CHAPTER II}

International Society of Ancient Asia, 660 B. c.930 A. D.

The Early Intercourse of Japan with the Korean Kingdoms and China.-In primitive times there was no international society or association of the different races as such. In the Orient as well as in the Occident the society of nations is the product of historic development. The original society of human beings was the family, or horde, from which an international society was ultimately developed through tribe, folk and national state. ${ }^{1}$ Passing over the development of Asiatic nations from the ethnological or sociological viewpoint, we find that the historians of China maintain that Chinese national life began with Fou Hi, their first great emperor, who established his dynasty in 2953 B. C. $^{2}$ The Korean mythology holds that the existence of that nation dates from the time when Tan-gun, or Wanggun, was, in the latter part of the reign of the Emperor Yao of China (в. с. 2357-2255), crowned by his father, Whan-ung, said to be a son of God (Whan-in). ${ }^{3}$ The Chinese and Koreans claim, like the Jews and the ancient Egyptians, to be able to trace their national existence back to a period centuries before Solomon erected his Temple at Jerusalem. Without entering into the myths and legends of Japan, it may be said that her national history commenced

1 Giddings, Principles of Sociology, pp. 157-169.

${ }^{2}$ Mailla, Histoire générale de la Chine, vol. i, p. 5.

${ }^{3}$ Korean Review, History of Korea, vol. for I901, pp. 33 et seq. 
when the Emperor Jinmu, the first Mikado, after the subjugation of the tribes on the mainland, established a capital at Kashiwabara in Yamato, 660 B. . . ${ }^{1}$

Intercourse among these Asiatic nations must have existed from an immemorial time, for China and Korea are situated in the same continent, and a Japanese junk can easily in one day's sail reach the Korean coast. Although Japan is much farther away from the Chinese coast, the Kuro-shio, or black current, which flows from the Indian Ocean along the Chinese coast and washes all the southern coast of Japan, has often brought the wrecks of Chinese ships to the island empire. Moreover, these fertile and tempting islands would have been attractive to Chinese and Korean emigrants. ${ }^{2}$ With such a physical environment, the islanders could not be a hermit nation. As to the primitive intercourse between Japan and Korea, its beginning, according to the Japanese chronicle, ${ }^{3}$ was the presence in Korea of the Japanese prince, Susono-o-no-mikoto, in the legendary age. It was also said that Ina-hi-no-mikoto, a brother of the Emperor Jinmu, went to Unabara (Korea), before the emperor came to Yamato. ${ }^{4}$

${ }^{1}$ Kojiki, the oldest chronicles of Japan, Chamberlain's English translation in Transactions of the Asiatic Society of Japan, vol. x, supplement issue, sec. 1, p. I45. See also Nihongi, the second oldest chronicles of Japan, Aston's English translation, vol. i, p. I32.

The authenticity of the greater part of ancient Japanese history down to about 400 A. D. is not acknowledged by occidental authorities, but it is affirmed by native historians and has been officially recognized by the government.

${ }^{2}$ Giddings, Inductive Sociology, p. 45. Agricultural fertility, fisheries, mineral wealth, commercial opportunities, etc., of the New World attract immigration.

${ }^{3}$ Nihongi, vol. i, p. 57. See also Dr. Takahashi's paper, Revue de droit int., I9or, vol. iii, no. 2.

${ }^{4}$ Kojiki, sec. xliii, p. I29. See also Takekoshi, History of 2,500 Years, p. 9. 
Referring to the coming of the Koreans to Japan, we find in the imperial proclamation of the eleventh year of the Emperor $\mathrm{Su}-\mathrm{jin}(97-30$ B. c.) the first mention of the word naturalization, ${ }^{1}$ which possibly shows the existence then of Korean immigration. Because the naturalization of Koreans in Japan was not officially recognized until the third year of the Emperor Suinin (30 B. C.-70 A. D.), the privilege of settling in the Tajima province was specially granted to the Korean prince, Ameno-Hihoko. ${ }^{2}$

The first Japanese contact with Chinese, it is said, took place when seven Chinese survivors of a shipwreck landed on the Kumano coast of the $\mathrm{Ki}-\mathrm{i}$ province in the reign of the Emperor Kosho, the fifth Mikado (475-393 в. c.). ${ }^{3}$ A Chinese chronicle mentions the departure of this party, in which Sin-fu was commissioned by his celestial monarch, Chewang-te, a tyrant of the Draconian type, to search for a medicine giving immortality. Sin-fu, in reply, intimated that such an elixir of life could be procured only on the Fuji Mountain in Japan, and left China for that country."

But whatever the early intercourse of Japan with foreign countries may have been in other ways, her first diplomatic intercourse with the Koreans began in the sixty-fifth year of the Emperor Sujin (33 в. c.) when the king of Okara, one of the Korean kingdoms, sent Prince Sonaka-Cheulchi and his suite to Japan as an envoy with a present to the Mikado. ${ }^{5}$ The envoy unfortunately did not secure an imperial audience, as the emperor was then ill. Several years

1 Gaiko-Shiko (The Digest of Foreign Intercourse), compiled by the Bureau of Records, Department of Foreign Affairs, p. 457.

2 Ibid.

${ }^{3}$ Gaiko-Shiko, p. 469.

$4 \mathrm{Mr}$. Nitobe gives an interesting account of $\mathrm{Sin}-\mathrm{fu}$ in his Intercourse between the United States and Japan, p. 5.

5 For a full account of the mission of the Korean envoy, see Nihongi, vol. i, pp. 164-167. 
later, however, he was received by the succeeding emperor, the Suinin. The new emperor expressed deep regret that " the honorable visitor had not been presented to his august father" and desired to call the state from which he was sent, Imna, that being the personal name of the Emperor Suinin, in order to commemorate his coming. ${ }^{1}$ Upon his departure the emperor made liberal gifts to the suite of the envoy, and entrusted him with Ioo pieces of red silk as a present for his sovereign.

The official intercourse of Japan with China is said to have been inaugurated by the lord of Ito(Southern Kiushu), whose envoy was often at the court of the Han dynasty in China, in the latter part of the reign of the Emperor Suinin. It was this intercourse of China with a local lord of Japan, that often led the old Chinese historians to pretend that Japan was tributary to China. But the Yamato government of Japan had no knowledge of the intercourse with China conducted by the local lord. ${ }^{2}$ In Japanese history it is often stated that Japan maintained relations with the Chinese courts of the "Three Kingdoms," which followed the fall of the Han dynasty; but the maintenance of such relations by the central government of Japan was infrequent until the beginning of the seventh century. The Emperor Suiko despatched Ono-no-Imoko to the court of the Soui dynasty in 607 A. D. with national products and an imperial letter, which was addressed as follows: "A letter from the sovereign of the Sun-rise country to the sovereign of the Sun-set country." ${ }^{3}$ The Japanese ambassador was cordially received at the Chinese court, where he was honored

1 In consequence the Japanese historians called Okara, Imna.

2 Gaiko-Shiko, p. 67.

3 Ibid., p. 69. The name Nippon (Land of the Rising Sun) is said to have had its origin in this incident. 
with the Chinese name "So-Inko." In the following year, 608 A. D., Ono-no-Imoko returned through the Korean peninsula, accompanied by a Chinese ambassador, Pei-ShihChing, who, with a suite of twelve persons, was sent in reciprocal acknowledgment of Japan's proffer of friendship. The Chinese embassy was received in July at the Bay of Naniwa with the most elaborate festivities by the people and the officials; ${ }^{1}$ and on October 12 the ambassador was received in imperial audience, at which time he read his credentials $^{2}$ and presented to the Mikado splendid gifts from his sovereign.

Japan, it will thus be seen, originally entered into diplomatic relations with China and Korea in a peaceful and cordial manner, in marked contrast with the bloody struggles by which, in European history, such relations too often have been established. Among the ancient Asiatic nations, there was, of course, no permanent embassy; the envoy stayed in the foreign capital only a short time, on his special mission. The exchange of presents, consisting of national products, was a significant feature of diplomatic usage, and was regarded as a token of friendly and peaceful relations.

Political Relations of Japan with the Korean Kingdoms and China.-The warlike islanders, becoming more cosmopolitan by the intermingling of the Chinese and Korean immigrants, and gaining in knowledge of the outer world and of the means of communication by sea, ${ }^{3}$ could not con-

${ }^{1}$ Nihongi, vol. ii, p. 136 .

2 The text of the credentials may be found in Nihongi, vol. ii, pp. 137 et seq.

${ }^{3}$ Nihongi, vol. i, p. 16r. Emperor Suijin issued a ship-building edict in 8I B. C.: "Ships are of cardinal importance to the Empire. At present the people of the coast, not having ships, suffer grievously by the necessity of land transportation. Therefore let every province cause ships to be built." As the result of this auspicious encouragement seagoing ships were later developed. 
fine their activities within the limits of their island home. Formerly Korea was composed of several independent kingdoms-Koryö in the extreme north, Shinra in the southeast, Pekche in the southwest and Imna in the extreme south, just as Great Britain was once composed of the separate nations-England, Scotland and Wales. Shinra and Imna were often at enmity over the sovereignty of Sampamon, a territory of three hundred square leagues contiguous to their frontier, the possession of which the latter kingdom regarded as vital to its existence. ${ }^{1}$ Ever since the first Imna envoy visited Japan in the reign of the Emperor Suijin, and reported the remarkable growth and activity of the country, the Imna government had been anxious to obtain Japan's assistance against Shinra encroachments; and eventually an envoy, Ushiki-ari-shichi-Kanki, was despatched to Japan to ask the emperor to send a skilled general to Korea. ${ }^{2}$ The emperor, after consulting with his ministers, in 27 B. C., commissioned General Shihotaritsu-hiko to restore the peace of the Korean kingdom. This was the first expedition ever sent out by Japan to maintain the integrity of a foreign state, and it is also the first example of the maintenance of the "balance of power" in Korea by means of an alliance with Japan.

Japan had been at peace with the Korean kingdoms for more than two centuries, when the Empress Regent Zhingo (20I-269 A. D.) undertook to invade them. The Kumaso, one of the leading tribes, frequently revolted in Tsukushi, ${ }^{3}$ had greatly embarrassed former emperors; and these constant disturbances were due to the encouragement given

1 Gaiko-Shiko, p. 356.

2 Ibid. See also Takekoshi, History of 2,500 Years, p. 27.

3 The present island of Kiushu, in which many Chinese and Korean immigrants then settled. 
by the Shinra kingdom. Especially prominent was the Kumaso rebellion during the reign of the emperor Chu-a-i (I92-200 A. D.), when the sovereign himself, commanding the navy, proceeded to Nagato (now Shimonoseki), to which place the Empress Zhingo was subsequently summoned. The imperial troops were mobilized in the revolted district, but the Kumaso were not to be conquered; and at length the emperor held a council, in which the empress declared that "the Kumaso were not worth destroying, but that, if Shinra were conquered, Tsukushi would be easily subdued." 1 The emperor hesitated to adopt this advice but in the midst of the campaign, in February, 200 A. D., he became ill and died, whereupon the empress withdrew the imperial troops from Tsukushi and undertook preparations for the invasion of Korea. In April the empress summoned her minister and made a declaration of war upon Shinra, ${ }^{2}$ in which she swore that she would command the imperial forces in the "appearance of a man," enthusiastically encouraged her minister and general and promised them to take " possession of the land of treasure." She did not, however, define the object of the war. Her minister answered, as "the object of the measure which the empress has devised for the Empire is to tranquillize the ancestral shrines, and the Gods of the Earth and Grain, and also to protect her servants from blame, with head bowed to the ground we receive the command." 3 An imperial order was issued in September to collect ships from the sea-coast provinces, and on October 3 sail was set from the harbor of Wani. When the formidable fleet, raising a thundering sound from drums, fifes and gongs, approached the Shinra

${ }^{1}$ Gaiko-Shiko, p. I7I.

2 Nihongi, vol. i, p. 228 , contains the text of the declaration of war.

8 Ibid. 
coast, the king of Shinra was so greatly terrified that he thought the country would be crushed by a single stroke. Therefore, taking a white flag, he went in person to the fleet of the empress to negotiate for peace, and solemnly promised that Shinra should "every spring and every autumn" pay a tribute and should bring " annual dues of male and female slaves." " On this occasion one of the Japanese generals said: "Let us put to death the king of Silla." But the empress solemnly forbade him, saying, "slay not the submissive." ${ }_{2}$ Even in these early days the "peace commissioner," the non-combatant, and the white flag were fairly respected. The empress accepted the proffered terms of peace and took eighty ship-loads of gold, silver and silk as indemnity. One of the higher officials of Shinra, named Mi-cheul-kwi-chi-kanki, was carried away as a hostage, ${ }^{3}$ it being the custom in ancient times to give hostages as a guaranty for the performance of treaties. Learning of the signal success of the Japanese invaders, the kings of Koryö and Pekche also came of their own motion without escort, and said: "Henceforth forever, [we] will not cease to pay tribute."

In consequence of these events, most Japanese historians have regarded the Korean kingdoms as states subject to or under the suzerainty of Japan; but the annual contributions to China and Japan appear really to have been in the nature of formal presents, given in token of amity and goodwill, with a view to avoiding aggressive demands. This is the more likely, since it was in spite of their long existent and admitted tributary relation to China that the Korean

${ }^{1}$ Nihongi, vol. i, p. 23I. The word "slaves" referred to Korean artisans, blacksmiths, carpenters, etc., whom the Japanese were anxious to obtain.
2 Ibid.
${ }^{3}$ Ibid., p. $23 \mathrm{I}$. 
kingdoms now assumed a similar relation to Japan. On the whole, the invasion of Korea by the Empress Zhingo, whatever its results may have been, was nothing but a measure of self-preservation against Koreans who encouraged insurrection in Japanese territory.

After this invasion, the Pekche kingdom, regarding the Japanese influence in the peninsula as essential to its proservation against the attacks of its bitter rival, Shinra, made constant efforts to cultivate friendship with Japan. In the pursuit of this object Pekche not only promptly paid tribute, in the form of annual presents, but also introduced the fine arts, literature and Buddhism into Japan. ${ }^{1}$ Shinra, on the other hand, looking upon the Japanese as barbarians, depended upon Chinese influence for political supremacy. During the period of 362 years after the empress's expedition, Shinra in more than twenty instances failed to send its contribution and insulted the Japanese envoys or attacked the Miyake, ${ }^{2}$ in Imna. Japan, in each instance, sent an envoy or a force to demand an explanation and redress. Discontented Shinra, under the pressure of Japan and Pekche, made extraordinary efforts to introduce military arts and munitions from China, and entered upon an aggressive policy. She had indeed already seized most of the provinces of Imna, and in $55^{2} \mathrm{~A}$. D. was preparing to invade Pekche. The king of Pekche, who was then at enmity with Koryö, the northern kingdom, which was friendly to Shinra,

1 During the reign of the Emperor Ojin (270-310), the Pekche king sent to Japan a celebrated scholar named Achiki, who was appointed tutor to the crown prince. By introduction of Achiki, another learned man, named Wani, came to Japan with Chinese books on literature and ethics; and he also brought with him blacksmiths, weavers and brewers.

2 The Miyake was a Japanese granary, established in Imna immediately after the Korean invasion of the Empress Zhingo, and ever afterwards superintended by a Japanese general. Nihongi, vol. ii, pp. 8, 13. GaikoShiko, p. 174 . 
forseeing the danger of a possible combination of his enemies, sent an envoy, who was accompanied by an envoy from Imna, on May 8, 552, to Japan, and requested the Emperor Kinmei (540-57 I) for an alliance. ${ }^{1}$ The next year several hundred Japanese soldiers were despatched to Korea and the peace of the peninsula was temporarily restored.

Shinra, however, increasing her forces on a gigantic scale, again undertook, in combination with Koryö, to overthrow Pekche and Imna. In January, 562, Imna had almost surrendered, and the Miyake was destroyed, when Pekche acquainted Japan with the situation and asked for the immediate despatch of a number of troops. In June the Emperor Kinmei declared war against Shinra, ${ }^{2}$ and he was engaged in fitting out an expedition, when, on July I, Shinra, cunningly seeking to allay his indignation, sent an envoy to Japan to offer the tribute which had been so often neglected. ${ }^{3}$ The emperor scornfully repulsed the Shinra envoy. In the middle of July the Japanese generalin-chief, Kino-wo-maro-no-sukune, was despatched to Shinra and General Sadehiko to Koryö, and, in alliance with the forces of Pekche and Imna, they entered into hostilities against Shinra and Koryö. After many battles the Japanese generals were defeated and withdrew from the peninsula without effecting a settlement. The result was that Pekche and Imna, the kingdoms most friendly to Japan, fell under the influence of Shinra and Koryö.

Pekche wished to restore the balance of power amongst the rival kingdoms; but, in order to do this, it was necessary to secure the assistance of China to check Koryö, which had been hostile to China ever since 230 A. D., because of

1 The full text of the communication is found in Nihongi, vol. ii, p. 65 .

2 Ibid., pp. 8I-82.

3 Ibid., p. 83. 
Chinese encroachments on the frontier. Japan's assistance, too, was required in order to check Shinra, her traditional enemy. For these reasons Pekche sent an envoy to the Soui emperor of China, and obtained from him the promise to attack Koryö; but the plan miscarried. ${ }^{1}$ The Chinese troops on the Korean frontier were defeated and driven out by the Koryö soldiers. Meanwhile the Soui dynasty had fallen. But, as soon as Taitsong the Great had established the Tong dynasty, he sent, in $6 \mathrm{r} 3 \mathrm{~A}$. D., heavy forces, to take revenge on Koryö. Though Koryö and Pekche were bitter enemies, they now regarded the Chinese as their common foe, and for mutual defence united against the Chinese invasion, which was utterly defeated. ${ }^{2}$

The military success of the two kingdoms aroused the jealousy of Shinra, the pro-Chinese state. Shinra, therefore, made an offensive alliance with the Tang emperor, who offered to send I00,000 men and several hundred vessels to the Pekchean coast. ${ }^{3}$ The allied force was so formidable that Pekche was about to surrender, leaving Koryö at the mercy of the invader, when, in October, 660 A. D., Kwisil Pok-sin, a Pekchean envoy and his suite, with a hundred prisoners of the Tang army, went to Japan and asked the Empress Saimei (655-66I) to relieve his country from the danger. ${ }^{4}$ The empress granted his request, considering that "to render help in an emergency" to the Pekche kingdom was the "unshakable" policy of Japan. An order for the expedition was issued. ${ }^{5}$ The imperial

1 Takekoshi, The History of 2,500 Years, p. I24.

2 Ibid.

${ }^{3}$ Griffis, Hermit Nation, p. 36.

${ }^{4}$ Nihongi, vol. ii, p. 268.

5 See Nihongi, vol. ii, p. 269 , for the full text of the order, in which the empress expressed her policy. The order is in the nature of a declaration of war. 
staff was, in July, 66r, advanced to Tsukushi. The crown prince, Naka-no-oye, superintended the fitting out of the imperial navy. Towards the end of the year, additional forces of the great Tang emperor invaded the Koryö frontier, and this was followed up in the spring of 662 by an attack from Shinra. Koryö was now in desperate straits. Her envoy came to Japan in March, and asked the empress immediately to despatch a large force. ${ }^{1}$ The Japanese court regarded the combined invasion of Koryö by China and Shinra as dangerous, not only to the integrity of the Korean kingdoms but also to the peace of the Mikado's dominions. It was feared that the Chinese, if victorious, might invade Japan. Therefore, the crown prince Naka-no-oye, with his general-in-chief, Adzumino-Hirafu-no-Muraji, commanding ten thousand men and one hundred and seventeen vessels, on August 5, 662, landed on the Pekchean coast. The Japanese forces, combined with those of Pekche and Koryö, immediately attacked the two allied aggressors, ${ }^{2}$ but they were not successful. They were utterly defeated in the last naval battle near the mouth of Naktong River, on August 27, 663. ${ }^{3}$

The triple alliance headed by Japan could not counterbalance the overwhelming weight of the dual alliance of the most progressive kingdom of Korea with the great Chinese Empire. The conflict resulted in the dismemberment of two kingdoms. Pekche was absorbed by Shinra, and Koryö in 668 was partitioned between Shinra and China. ${ }^{4}$ Thus the life of the several Korean kingdoms was terminated. After the defeat at the Naktong River, the crown prince Naka-no-oye (the Emperor Tench) changed the foreign

1 Nihongi, vol. ii, p. 277.

2 Ibid., pp. 277-278.

3 Ibid., p. 28o. See also Boulger, History of China, vol. i, p. 292.

4 The present Liao Tung peninsula originally belonged to Korea, but it became a Chinese possession in ,668 A. D. 
policy of Japan. He established the principle of non-interference in the affairs of the Korean peninsula, and forbore to seek revenge upon China. This most prudent sovereign made indeed every possible effort to restore amicable relations among the Asiatic nations. When, therefore, the Tang emperor sent an envoy, named Liu-te-Kao, to Japan in 665 , he was received with high honors and a Japanese envoy was soon sent to China in return. ${ }^{1}$ The war had not, however, annulled the tributary relation of Korea to Japan, for Shinra, in 668, sent an envoy to Japan with handsome tribute. $^{2}$ The abandonment of political interference in Korea by the Emperor Tenchi did not escape criticism by the historians of succeeding generations. But his policy is justified by the maintenance of the Japanese national dignity, and by the preservation of the peace of the Orient which resulted from it.

Internal Affairs of Ancient Japan.-The Emperor Tench not only conducted wisely the foreign affairs of the country, but also showed great ability in the reform and improvement of the internal administration.

The national state of Japan was originally based upon the principle of theocracy ${ }^{3}$ as was that of all nations of the early ages. The Emperor Jinmu, the first Mikado, is said to be the divine descendant of Amaterasu-Omikami, the Celestial Deity, who descended from heaven and created the land of Oyashi-ma (the original name of Japan). The sovereignty in Shintoism " (the Japanese theocracy) ex-

1 Nihongi, vol. ii, p. 284.

2 Ibid., vol. ii, p. 289.

3 Burgess, Political Science and Comparative Constitutional Law, vol. $i$, p. 6o. The earliest form of the state is theocracy, which was the contribution of Asia.

4 Shinto is the original religion of Japan. For a general account of Shintoism, see Chamberlain, Things Japanese, pp. 358 et seq. As to the conception of sovereignty in Shintoism, see Siebold, Japan and the Comity of Nations, p. 7 . 
isted not only by the "grace of God," but further in virtue of descent from the ancestral creator of the lands of Japan. All Japanese rendered their loyal "deference and obedience" to the virtue and power of the Mikado. While the sovereignty of other nations was often altered through conquest, the Japanese maintained an "unbroken line of illustrious imperial sovereigns" and never recognized any ruler from any other source.

The administrative function and organization was, in the reign of the Emperor Jinmu (66o- 585 B. c.), very simple. The princes Ama-no-Taneko and Amatomi superintended civil and religious matters, and the princes Umashi-machi and Okume attended to military affairs. ${ }^{1}$ These princes had the official titles of Omi and Muraji, the former referring to the civil office, and the latter to the military. In the reign of the Emperor Suinin the office of Ohmuraji, commander-in-chief (a head of Muraji), was initiated. In the reign of the Emperor Seimu (I3I-I9O A. D.) that of Oh-omi, prime minister (a head of Omi) was established. Since the reign of the Emperor Yuraku (457-479) both offices have existed side by side. ${ }^{2}$ As to local administration, the general or soldiers who had shown merit in subduing hostile tribes or in suppressing insurrections, were appointed to Kuni-no-Miyatsuko (governorships of provinces), Agata-Nushi (headships of districts) and Inaki (squires of villages). ${ }^{3}$ In the course of time the Mononobe, Imbe, Nakatomi and Kume families sprang from the princes already mentioned. The Soga family was de-

1 History of the Empire of Japan, compiled under the direction of the department of education, at the request of the Imperial Japanese Commission to the World's Columbian Exposition in Chicago, translated by Captain Brinkley, p. 27.

2 Nihongi, vol. i, p. 337 . See note.

${ }^{3}$ Ariga, Kokuho-gaku (Public Law of Japan), vol. i, pp. 26 et seq. 
scended from Takenouchi-Sukune, who was the commanderin-chief in the Korean expedition of the Empress Zhingo. Government offices, civil or military, central or local, became hereditary in these families. The common people, in these ancient days, were nothing more than serfs, the property of the governing classes, as in every primitive country. The early form of government of Japan was thus that of a tribal feudal system under the Mikado.

The Mononobe and Soga families, gradually growing in power, acquired the Oh-muraji and Oh-omi as their hereditary offices. The administration of the country thus remained largely in the hands of these two families. For some time previously the Mononobe and Soga had been wrestling for the supremacy. The introduction of Buddhism in the sixth century had served to accentuate their hostility. The former was conservative, adhered to the national religion-celestial Shintoism-and opposed the spread of Buddhism. The Soga family was an enthusiastic adherent of the foreign religion, to which the imperial house was at first opposed, but which it was later inclined to adopt. With the assistance of Prince Shotoku, the most enthusiastic leader of the new religion, Soga-no-umako killed the Mononobe-no-moriya in 587. After this event, the Mononobe family was ruined and the Soga house became predominant. In order to obtain the supreme power, the Soga family essayed to interfere in the succession to the throne. Immemorial custom was the basis of the public law of Japan. Soga-no-umako endeavored to place Princess Kashiya, the consort of the Emperor Bidatsu, who was favored by the Soga family, on the throne under the title of the Empress Suiko (595-628), despite the presence of direct successors in the male line. ${ }^{1}$ The autocratic power of Imishi, of the Soga family, was still more pronounced;

1 Ariga, Kokuho-gaku, vol. i, p. 35 . 
but it was surpassed by that of his son Iruka who attempted to destroy the lineal succession to the imperial throne by causing Prince Yamashiro, the legitimate successor, to be killed, and by putting in his place Prince Furuhito-no-oe, a relative of the Soga family, hoping thereby in the end to usurp the supreme power for himself. But his treacherous design was discovered in time, and "father and son of the Soga" were killed in 645 by Prince Naka-no-oye, with the assistance of the Nakatomi-no-kamatari, one of the most loyal families. Prince Karu then ascended the throne; Prince Naka-no-oye became the crown prince and, presiding over the administration of the country, took up with Nakatomi the work of sweeping reforms.

On November 19, 645, the new Emperor Kotoku, accompanied by the empress dowager and the crown prince, made a solemn declaration before all the ministers and generals :

Heaven covers us; Earth upbears us; the imperial way is but one. But in this last degenerate age, the order of lord and vassal was destroyed, until supreme Heaven by our hands put to death the traitors. Now, from this time forward, both parties shedding their hearts' blood, the lord will eschew the double method of government, and the vassal will avoid duplicity in his service of the sovereign. On him who breaks this oath, Heaven will send a curse and earth a plague, demons will slay him, and men will smite him. This is as manifest as the sun and moon. ${ }^{1}$

This oath clearly defines the comprehensiveness, exclusiveness and permanency of the imperial sovereignty and the duty of the vassal. In the succeeding years, various edicts were promulgated regarding the administrative functions, census, taxation, etc. ${ }^{2}$ Omuraji and Ohmi were replaced

1 Nihongi, vol. ii, p. 197.

2 Ibid., vol. ii, pp. 206-209 and 226-230. See also History of the Empire of Japan, pp. 68-77, as to the Taika reformation. 
by three new offices, viz. : Minister of the Left, of the Right, and of the Middle. The territorial unit of the administration and the estates of the privileged families were abolished. The test of ability was introduced in the appointment of officers. The system of Densho, or the private ownership of serf and land by the official class, was done away with by the nationalization of the land and the establishment of the Shoku-ho or wage system. The labor contribution was abolished and a system of commuted taxes was introduced. Under the new administrative measures, registers of population, books of accounts and records of censuses were ordered to be kept. Thus the old system of tribal feudalism was replaced by a central administration. These measures, inaugurated upon the suppression of the Soga treachery, constituted a conspicuous reform in the political history of Japan. They were named the Taika Reformation, because they were introduced in the Taika era. The subsequent edicts promulgating these measures are said to be the first constitutional manuscripts of Japan. ${ }^{1}$ The Taika reformation was greatly influenced by Chinese civilization. The centralized institutions of the Soui and Tang dynasties had been studied by Japanese scholars since the first Japanese envoy, Imo-ko, went to China. After the Emperor Tench restored peace with China, the Japanese were more interested in Chinese institutions and further adopted the Chinese codification. In the era of Taiho (702 A. D.), the Emperor Monmu promulgated a systematic body of codes, embracing administrative organization and functions, the imperial household and succession, official ceremonies, and criminal law in a rudimentary form, with a little civil law. ${ }^{2}$ The Taiho code is but the comple-

1 Ariga, Kokuho-gaku, vol. i, p. 37.

2 For the classification and table of the Taiho code, see History of the Empire of Japan, pp. 87-89. 
tion of the codification of the fragmentary edicts since the Taika reformation.

To sum up, the imperial power was, by the Taika reform, restored, and the Mikado became the real ruler, controlling all matters of peace and war. All the people of Japan were made direct subjects of the emperor, thus cementing the national life of Japan more firmly. From the Taika reform, (645) to the end of the reign of the Emperor Daigo (898-930) was an auspicious period for the imperial sovereignty. This period is known in Japanese history as the "enlightened epochs of Nara and Heiau," epochs worthy of special reference because of the prosperity then enjoyed by the successive Mikados, and because of the development of civilization that took place with tranquillity at home and abroad. 


\section{CHAPTER III}

\section{Dreams of Universal Empire, 894-I 595}

The Activity of the Mongol Tartar.-The history of mediæval Europe is known as the "dark ages." Reckless war, civil or international, the attempt to establish universal empire by destroying all national states, and piracy on the sea were the dominating features. So it was in Asia.

The period of imperial prosperity after the Taika reformation did not last long. Because of the invaluable services of Nakatomi, in defeating the Soga treachery and bringing about the Taika reformation, his descendants, men of the Fujiwara family, were permitted to enjoy the ministerial offices of the crown. They eagerly introduced the Chinese system of bureaucratic centralization and gradually founded a strong autocratic government. Daughters of the Fujiwara family often became the consorts of the emperors. Yoshifusa Fujiwara was appointed Dajio Daijin (prime minister) and Sessho (regent of the crown), offices which hitherto had been given only to princes of the imperial family. His adopted son, Mototsune, occupying these higher offices, interfered with the succession to the throne, and deposed the Emperor Yosei (877-884) and placed the Emperor Koko in his stead. Thus the imperial power was about to pass into the hands of the Fujiwara family. Though the Emperor Daigo (898-930) temporarily restored the imperial authority with the loyal assistance of Michizane Sugawara, the succeeding emper- 
ors were under the Fujiwara influence. The decline of the imperial power, though hastened by the crafty autocracy of the Fujiwara, was, to a great extent, influenced by Buddhism. ${ }^{1}$ Its pessimistic doctrine affected the Mikados of the following generations. They became weary of affairs of the world and renounced political activity. On the other hand, the administration of the Fujiwara ceased to be strong enough to control the lords of the remoter provinces, who, having originally been local officials, had gradually become feudal lords possessing territory and residing in castles. Under such conditions, civil war, rebellion, revolution against the central government and struggles for supremacy among the rival provincial lords themselves became common. Therefore the offices of Kebii-shi (military police) in each province and Oryo-shi (inspector-general) in the northern provinces, where rebellion chiefly occurred, were established and empowered to exercise police functions with armed force. ${ }^{2}$ The Fujiwara, not possessing adequate force themselves, filled these military offices with representatives of the military families, especially the Taira and Minamoto. These two military clans gradually grew in strength and eventually displaced the Fujiwara family; but in course of time they entered into a struggle for supremacy, which was prolonged until Minamoto Yoritomo subdued the Taira family. Yoritomo, after subjugating all the feudal lords, finally established Bakufu, a military government, at Kamakura, in the province of Suruga, in II86. He styled himself "Shogun" (generalissimo). Thereafter the Minamoto family ruled the political and military affairs of the country, from Kamakura. The dual system of government was thus

${ }^{1}$ Griffis, The Mikado's Empire (9th ed.), p. 114.

${ }^{2}$ History of the Empire of Japan, pp. I34-I35. 
inaugurated in Japan, the Shogun maintaining a de-facto sovereignty, and leaving the de-jure sovereignty to the Mikado, as a figure-head, at Kyoto. Identically the same thing occurred in China when the downfall of the Tang dynasty was followed by the military struggle of the five petty dynasties. Constant civil war prevailed in China as in Japan. Under such conditions, piracy in Asiatic waters was a natural outcome, and commercial intercourse could not be maintained. Japan discontinued diplomatic intercourse with China, after Michizane Sugawara in 894 advised the Emperor Daigo not to send an envoy to China, on account of the unsafe conditions on the high sea and the existence of civil war in China. ${ }^{1}$ Japanese intercourse with Korea was frequently interrupted. ${ }^{2}$ Korea had often neglected to send the annual embassy to Japan, having taken advantage of the civil war of Taira-Minamoto. In short, international intercourse among Asiatic nations almost ceased to exist, owing to piracy on the sea and civil war on land, until the Mongol Tartar overwhelmed Asia in the thirteenth century.

The Tartar tribes, at even so early a period as 238 в. с., were so feared by the Chinese that the Great Wall was constructed as a defense against the " northern barbarian." Century after century the Tartars were steadily gaining in power, absorbing the tribes of Siberia and encroaching upon northern China, until they finally formed a gigantic dynasty called the Khan Empire. The Mongol Tartar, in the beginning of the thirteenth century, was surging from the grassy plains of Manchuria over the Asiatic and even the European continents; and the wave flung its last drops of spray over Japan. While Ghingis Khan was wrestling with the Zung

1 Gaiko-Shiko, p. 95.

2 In 918 the name of the Shinra kingdom was changed to Korai. 
dynasty in China, a division of his armies, under General Sal-ye-tap, moved into the Korean peninsula through the Liao Tung frontier and crossed the Yalu river in the spring of I23I. The general then sent from his camp to the Korean king, Ko-jang, a letter demanding his surrender. ${ }^{1}$ The king at first took up arms, but he finally surrendered to the demand of the invaders in 1232, offering valuable tribute of gold and silver and declaring himself a vassal of the Mongol. The latter now established military governors to control the administration. These governors had little respect for the Korean court, and oppressed Korean subjects with heavy contributions. The Korean king, according to the advice of his minister, had moved his court to Kang-wha Island, rather than behold his own disgrace. $^{2}$ This caused the second invasion of the Mongol and hostilities did not cease until the crown prince was despatched, in I259, to the Mongol court to pay homage. During the stay of the crown prince at Peking, Kublai, grandson of Ghingis Khan, ascended the throne in I260. The new emperor treated the. Korean with the utmost kindness, and the latter, on his return to Korea, finding that his father had died, ascended the throne, in I26r. Kublai, perceiving that a good opportunity had come to persuade the new Korean king to absolute submission, wrote him a letter, ${ }^{3}$ pointing out the dangers in his situation and the great benefit to be derived from a coalition. By this threatening but placating diplomacy, the Korean king was induced to become an obedient vassal and ally of Kublai. At this time the Emperor Sung of China was on the verge of being overthrown; and Kublai, having subjugated almost

${ }^{1}$ Korean Review, History of Korea, vol. i, p. 528.

2 Ibid., vol. i, pp. 563-565.

${ }^{3}$ For the text of letter, see Mailla, Histoire de la Chine, vol. ix, p. 292. 
all the Asiatic continent, now conceived the project of bringing Japan within the sphere of his influence.

His first step toward consummating this design, was to try to conquer Japan by diplomacy, and to this end he appointed Heuk Chuk and Fun Hong as envoys in I266. He gave them a letter addressed to the ruler of Japan, in which he observed that it was customary for a vassal to send a congratulatory message to the emperor on his coming to the throne, and complained that no such message had been sent by Japan. ${ }^{1}$ He further demanded of Japan that an envoy be sent to Peking at the earliest possible time in order to avoid forcible subjugation. The envoys were instructed to proceed to Japan by way of Korea and to take with them to Japan a Korean envoy who understood Japanese affairs. The envoys set sail for Japan by the way of Koje harbor (present Masampho), but were driven back by a stormy ocean. The Korean envoy, who was not willing to guide the messengers of the aggressive Mongol to Japan, exaggerated the danger and difficulty of the voyage and finally dissuaded the Mongol envoys from their undertaking. The latter, being unaccustomed to the sea, abandoned their mission and returned to Peking. Two years later, Kublai sent another ambassador to the Dazai-fu of Kuishu (the branch office of foreign affairs of Japan) furnished with a letter addressed to the "King of Japan." 2 Japan was, at this time, under the régime of the Hojo family ( $125^{-1} 333$ ), which had succeeded the military government of the Minamoto family, and Tokimune Hojo was administering the affairs of the country. The letter from Kublai was for-

${ }^{1}$ Mailla, Histoire de la Chine, vol. ix. For copy of the letter, see pp. 303-304.

2 This letter contained substantially the same demands which were made by Kublai in his previous letter in 1266 . The text of the letter, in the Japanese language, is in Gaiko-Shiko, sec. 6, p. 254. 
warded by the governor of the Dazai-fu to Tokimune, by whom it was in turn sent to the imperial court at Kyoto. A draft of a reply, in which every demand made by Kublai was refused, was prepared and handed over to the Kamakura government. Tokimune, however, a military statesman, considered that a communication from a foreign ruler in which the dignity of Japan was insulted, should not be treated so respectfully, and he gave instructions to the Dazai-fu for the immediate expulsion of the Mongol ambassador, without any answer to the letter. This news caused much anxiety throughout the empire, and it was feared that the Mongol would invade Japan. The Emperor Kameyama commissioned Michimasa, to lay before the shrine of Daijingu (the Deity of the Ancestor of the Imperial Sovereign) an autographic supplication for the heavenly protection of the country. All priests were ordered to follow the same example in their temples. On the other hand, careful measures were taken to guard the southern coasts. Kublai being still at war with the Sung forces, his whole army was not available for the invasion of Japan, and he sent orders to the Korean king to furnish one thousand bags of rice and a contingent of 40,000 troops. $^{1}$ A second Korean envoy was sent to Japan in I 269 to demand an answer to the letter of I268, but he was ruthlessly expelled by the governor of Tsushima island. This envoy, on his way home, captured two Japanese, Tanjiro and Yajiro, and sent them to Peking. Kublai was exceedingly delighted with the "valuable prisoners" and showed them his brilliant palaces and grand military parades. The two Japanese were then sent home to tell their ruler about the greatness of the Mongol emperor and to urge him to make Japan a vassal of the Mongol em-

${ }^{1}$ Korean Review, History of Korea, vol. ii, p. 38. 
pire. ${ }^{1}$ Their report, however, caused Japan to stand even more firmly against the world-aggressor. Kublai completely overthrew the Sung dynasty in China and established his own in the name of Yuen, in I27I ; and being now freed from internal opposition, he took more decisive steps in dealing with Japan. In September he sent a third ambassador, Chiu Liumgpat, with a suite of one hundred followers. This ambassador did not entrust his original letter to the officials of the Dazai-fu, but demanded that he be allowed to hand it to the emperor or shogun in person. As he was not permitted to proceed to the capital, a copy of the document was subsequently given to the governor of the Dazai-fu and forwarded to Kamakura, and from thence to Kyoto. In the letter Kublai complained that no answer had been given to his previous communications and demanded that an embassy be sent to the Yuen dynasty to restore amicable relations, and he hinted that any delay would cause a war. He limited the time during which he would await an answer to the end of November. ${ }^{2}$ Again the imperial court and the Kamakura government decided, in December, to give no answer. Again the emperor caused the whole country to pray for the divine support of the national existence. In I272 and during the following year Mongol envoys came to Japan from time to time; some of them were expelled and some were killed, for Japan regarded their demands as a national insult.

Incensed at the conduct of Japan, Kublai renounced diplomacy and sent an " invincible armada," consisting of 900 war vessels and 25,000 Mongol-Chinese, under Generals Hol Fon, Hong Ta-gu and Yu Pokhyong, and I5,000 Koreans under General Kim Pang-gyung. ${ }^{3}$ In November,

1 Gaiko-Shiko, sec. 6, p. 256.

2 Ibid., p. 257.

${ }^{3}$ Korean Review, History of Korea, vol. ii, p. 44. 
I274, the invaders arrived at Tsushima island. In spite of the vigorous resistance of the governors and their troops on Tsushima and Iki islands, the Mongols easily occupied these places, and directed their main forces against the Chikuzen coast of Kiushu. The military lords of Kiushu, Shoni, Otomo, Matsu-ura, Kikuchi, and others, rallied to the national defence. The Mongol invaders, armed with fire engines, called $D o,{ }^{1}$ and equipped with the improved weapons which had been introduced by the Venetians, caused great havoc among the Japanese forces, and the invaders were about to occupy the mainland, when, fortunately for Japan, a raging typhoon broke upon them, many of their war vessels were destroyed, and the remainder of their forces escaped under cover of darkness.

This disaster did not cause Kublai to abandon his designs upon the Island Empire. In the next year, 1275, he despatched envoys in order to bring Japan to terms; but the Japanese, rendered confident by their naval victory and their insular position, refused to yield to his threats. The repeated expulsion and persecution of the Mongol envoys caused the second invasion of Japan. During 1280 great preparations were made in all the harbors of Kiangsu, Chekiang and Fuken for the expedition against Japan. The Mongol armada, consisting of 1000 vessels, and having on board 20,070 Korean soldiers and 50,000 Mongols under the command of Hwan Bunko, appeared in Japanese waters in May, 1281. ${ }^{2}$ Not only were the entire army and navy of Kiushu Island called into service, but numerous forces from the mainland under Commander Hojo Sanemasa, brother of the Shogun, Tikimune, were pressed into

${ }^{1} D o$ was a machine for throwing blazing arrows into the ranks of the enemy.

2 As to the number of the Mongol force, see Korean Review, History of Korea, vol. ii, p. 8r. 
the campaign. The Mongol invader, however, enjoyed the great advantage of possessing much heavy ordnance, with which Japanese forts were bombarded and numberless soldiers slaughtered. While the islanders were desperately defending their empire, a rumor spread that the Mongol invaders, having crushed all resistance, were pushing on to the main island and were on the point of advancing to the capital. The emperor, much distressed by this national misfortune, proceeded in person to the Hachimanku shrine (God of War) of Iwashimisu to pray for national tranquillity, and he also sent an autographic supplication to the shrine of Daijingu as he had done before. While the contest was being fiercely continued in Kiushu, a northwest gale washed away the foreign invaders on July 30, I28I, and wrecked many of their ships, with great loss of life. Several thousand of the wrecked warriors took refuge on the island of Takashima, off the coast of the province of Hizen, where General Shoni Takasuke executed all of them except three persons, ${ }^{1}$ who were sent to China to report the fate of the great expedition. Kublai, a man full of ambition, a type of the oriental hero, would not abandon the dream of world-empire. In the following years he again made energetic preparations towards repairing his former defeat, and in 1283 he ordered the Korean king to increase his naval equipment. But, in 1286, on the advice of General Lieousinen, his chancellor, the "Emperor of Earth" abandoned all further designs upon Japan. ${ }^{2}$

It has been said that Japan spent as much money for re-

1 While a Japanese record describes three persons as having arrived safely at China, a foreign authority mentions eight persons. See GaikoShiko, p. 261. See also Yule, The Book of Sir Marco Polo, vol. ii, note to page 243 .

2 The text of the advice is in Mailla, Histoire générale de la Chine, vol. ix, pp. 427-428. 
ligious services at shrines and temples throughout the empire as was spent for military operations during these national crises. $^{1}$ Of course the people and historians of those days attributed their successful defence to the "heavenly support." As a matter of fact their naval fighting was far superior to that of the continental soldiers. Nevertheless, it must also be admitted that an island nation is better protected by nature against foreign invasion than are continental nations.

The Result of the Mongol Invasion-Period of Piracy.The attempt at Mongol universalism had little or no direct influence upon Asiatic civilization; but, in the reaction that followed, there was produced one most evil result-a swarm of pirates in Asiatic waters. After the military activities of the Mongols were checked by the Teutons in the West and by the islanders of Japan in the extreme East, the southern Chinese, tiring of their military absolutism, soon set to work upon the destruction of their mighty empire; and, while rebellions against the Mongol governors prevailed throughout southern China, pirates swarmed on the seaboard, and Mongol fleets were captured by the celebrated pirate Frangkue Chin in the beginning of the fourteenth century. ${ }^{2}$ After that, Chinese piracy was rampant on the coast of southern China and in the Indian ocean. Moreover, the Japanese, after the Mongol invasion, bitterly hated the Mongol and his ally, the Korean, and many of the soldiers and sailors who had defended their country became pirates and revenged themselves upon their old foe by raiding the Liao Tung and Shan Tung peninsulas, and the Korean coast as well.

Japan again drifted into civil war in the beginning of

1 The History of the Empire, p. 189.

2 Boulger, History of China, vol. i, p. 602. 
the fourteenth century; the military government of the Hojo family at Kamakura was destroyed, and the Emperor Godaigo (I3I8-I339) temporarily restored the imperial authority, through the loyalty of the Nitta and Ashikaga families. But the rivalry of these two families soon caused another civil war, the so-called "War of Chrysanthemums," and the imperial power was again clouded. Takauji, of the Ashikaga family, established the Shogun government at Kyoto in $\mathrm{r}_{342}$. Taking advantage of these civil disturbances, the Japanese pirates of the southern provinces became more and more aggressive in their descents upon the Korean and the Chinese coasts. The national guards of Korea often fought in vain at the seaports with the adventurous Japanese raiders. In order to warn the people of the approach of piratical invasions, the Korean government now adopted the "signal fire" in the national service. $^{1}$ Combining with Chinese pirates, the Japanese marauders often raided the districts of Shantung, Fokkien and Sikkong, burning towns, killing defenceless people and even fighting with regular soldiers. In those days, the Koreans and the Chinese feared the Japanese pirates more than the Europeans once dreaded the Vikings, and they were accustomed to call the Japanese pirate Wai-Kol (the dreadful creature of Japan). Although Takauji and the second Shogun, Yoshimori of Ashikaga, re-established the internal administration of the country, the piracy in the southern provinces was entirely beyond their control. Thus, on account of frequent civil wars and piracy, diplomatic and commercial intercourse among oriental nations hardly existed for many generations after the Mongol invasion.

Official intercourse with Japan was revived by China and

${ }^{1}$ Griffis, Corea, the Hermit Nation, p. 74. 
Korea at the end of the fourteenth century-not for the purpose of exchanging courtesies and sending tribute as in ancient times, but for the purpose of making complaints against Japanese piracy. In 1367 the Korean king sent an envoy to Japan for the latter purpose. ${ }^{1}$ In the following year order was restored in China by the establishment of the Ming dynasty; and in 1369 an envoy was sent to Japan to convey information of the change of sovereigns as well as to ask that measures for the suppression of piracy be taken. ${ }^{2}$ From this time on, China and Korea repeatedly despatched envoys to Japan to demand redress for the ravages of the pirates; but the Japanese government usually claimed to be unable to control them. Yoshimitsu, the third Shogun of the Ashikaga family (I368-1393), greatly appreciated, however, the arts and luxury of China and Korea; and it was he who took the first step for the suppression of piracy, in order to foster commerce with those countries. ${ }^{3} \mathrm{He}$ frequently sent envoys to their courts and on several occasions caused expeditions to be sent to the piratical districts. The Chinese government appreciated these measures, and, when Yoshimitsu died, honored the deceased Shogun by conferring on him the title of "Kyoken-O" (King of the Sages), and in 1404 issued the "Kan-go" to Japanese merchant ships in order to distinguish them from piratical junks. ${ }^{4}$ Subsequently, a member of the Ouchi family, a lord of Kiushu, was deputed by the Shogun government to watch the pirates on the southern coast, and to take charge of Chinese trade. A member of the So family, the gov-

1 Gaiko-Shiko, p. 218.

2 Ibid., pp. 99 and 263.

${ }^{3}$ Ibid., p. 223. See also Korean Review, Korean History, vol. ii, p. 190.

4 Gaiko-Shiko, p. 746. Kan-go is the return ticket, or duplicate, issued by the Chinese government as a passport to Chinese ports. 
ernor lord of Tsushima, who was accustomed to deal with the Koreans, was designated to manage the intercourse with that country. In I 443 So Sadamori negotiated a treaty ${ }^{1}$ with Korea, by which the So family might annually send fifty Japanese vessels to Korea, in order to export 20,000 koku of Korean beans and rice to Japan. Similar trade franchises were obtained by several other feudal lords of Japan. Under such auspicious conditions the foreign intercourse of Japan - official and commercial - flourished for several generations.

The Shogun government of the Ashikaga family, however, gradually became corrupt and ceased to be strong enough to control the powerful lords who had accumulated fortunes and retainers for many generations. A great civil war, known in Japanese history as the " complication of the Onin," began in 1467, and again brought on a crisis in foreign affairs. The conflict degenerated into military anarchy and lasted a century, till Oda Nobunaga set about restoring order in I573. During these dark days the Japanese pirate, who had been termed "Papan-sen" by the Chinese, ${ }^{2}$ again dominated Asiatic waters and foreign intercourse with Japan almost ceased.

The Attempts of Taiko the Great to subjugate China and Korea. - Toyotomi Hideyoshi, the greatest hero that Japan ever produced, though he was of humble origin, quickly raised himself to the position of one of the most prominent generals of Nobunaga, the general-in-chief. In a conversation with Nobunaga, Hideyoshi, when about to set out on an expedition to the Kiushu provinces, remarked

1 Gaiko-Shiko, p. 725.

2 In those days the Japanese pirate ships used a flag on which the legend "Hachimansen" (the fleet of the War-God), was written; the Chinese pronounced the ideographs "Papan-sen." 
that it would be possible to subdue Korea with one year's revenue of Kiushu, and then with a Korean army to conquer China, and thus to make China, Korea and Japan one ; ${ }^{1}$ and when, in 1582 , Nobunaga, on account of the sudden attack of his treacherous general, Mitsuhide, was forced to kill himself, the work of national unification, which Nobunaga had begun, was carried to completion by Hideyoshi.

Hideyoshi's extraordinary success in subjugating all the feudal lords and establishing administrative control over the country induced him to attempt to realize his immoderate ambition, namely, the founding of a universal empire in Asia. As a preliminary step, he sent a messenger to So Yoshitomo, the governing lord of Tsushima, who had superintended the Korean trade for a long time, directing him to take measures for the restoration of the old tributary relation of Korea to Japan and to demand that Korea act as an intermediary to secure from China a tribute to Japan in order to preserve friendly relations. ${ }^{2}$ In conformity with this plan, Aburatani, a retainer of the daimio So, was sent as envoy to Korea. Aburatani demanded of the Korean king that he send an envoy to Japan, in order to restore the old relations; but the king politely refused to do so, excusing himself on the ground of the dangers of navigation. ${ }^{3}$ In the spring of 1589 , Hideyoshi commissioned Lord So Yanakigawa and the monk Genso to act as envoys to Korea, and they renewed the demand for the immediate despatch of an envoy to Japan. After waiting for several months, they received an answer to the effect that the king would send an envoy on condition that Japan should seize and deliver up a number of Korean pirates who were raiding the

${ }^{1}$ Dening, Life of Toyotomi Hideyoshi, p. 263.

2 Gaiko-Shiko, p. 227.

${ }^{3}$ Korean Review, History of Korea, vol. ii, p. 424. 
southern seaboard in company with Japanese. ${ }^{1}$ This condition was duly fulfilled, and the Korean king then appointed Whang-yan-gil, Kim-Sungli and Ho-sung as an embassy to Japan. Accompanied by the Japanese commissioners, they arrived at Kyoto in May of 1590 ; and in September, an audience having been granted them, they presented to Hideyoshi the royal letter and the tribute. ${ }^{2}$ Hideyoshi, however, was not satisfied, as the letter made no reference to China; and, when the Korean envoys were about to depart, he gave them an answer, the substance of which was that the king of Korea should open his country to the Japanese forces, and that the Korean army should co-operate with them in an attack on China. ${ }^{3}$ As Korea had since the advent of the Mongol dynasty, depended more upon China than upon Japan, it is no wonder that the ambassadors declined to accept this proposal. Nevertheless, Hideyoshi dispatched to Korea an envoy, who persistently demanded a definite and favorable answer. The Korean government, on the other hand, sent a messenger to Peking, to warn the Chinese court of the projected invasion; but, before his arrival, information of Hideyoshi's designs had reached the court from the king of the Loochoo islands, who had just been in Japan, paying homage to Hideyoshi. ${ }^{4}$ The diplomatic interchanges between Japan and Korea ended with a mission of the So family in the spring of I59I, which failed to secure the co-operation of Korea in an invasion of China.

Hideyoshi, in the council of the elder generals, decided

${ }^{1}$ Korean Review, History of Korea, p. 425. See also Gaiko-Shiko, p. 227.

${ }^{2}$ The text of the letter and the list of tribute may be found in Aston, "Hideyoshi's Invasion of Korea," Transactions of the Asiatic Society of Japan, vol. vi, p. 231 .

3 Ibid., p. 232. See also Gaiko-Shiko, p. 228.

4 Transactions of the Asiatic Society of Japan, vol. vi, p. 223. 
to invade the Asiatic continent and issued a decree proclaiming war measures. ${ }^{1}$ Almost a year was spent in preparations. ${ }^{2}$ Hideyoshi gave up the office of Krvampbaku (regent of administration) to his son, Hidetsugu, assuming for himself the title, Taiko (the Great Lord); and freed from the cares of internal administration, he concentrated his efforts on the foreign expedition. In March, I 592, the Taiko proceeded to Nagoya, in Kiushu, where his headquarters were established. A force of $\mathrm{I}_{5} \mathrm{O}, 000 \mathrm{men}$, including sailors and soldiers, in eight divisions under as many generals, which had gathered at Nagoya, set out for Korea in April. The conditions were favorable to the Japanese. Their warlike spirit had under feudalism, from the time of the struggle between Taira and Minamoto, been constantly developed, and it was intensified by the Mongol invasion. Although dissipated in the military anarchy of the Onin, it was revived and concentrated by Nobunaga, and it was now about to be directed to a foreign invasion by the Napoleon of Japan. Besides, many of the Japanese soldiers were equipped with firearms ${ }^{3}$ which were destined to play an important part in the war. On the other hand, Korea and China had enjoyed peace for more than a century, and their people were unwilling to take up arms; nor had they become so well acquainted with the use of firearms as the Japanese. Nevertheless, the Koreans made elaborate preparations for the defence of their kingdom.

One division of the Japanese forces under General Konishi, in spite of desperate naval resistance, landed in Korea near Port Fusan on April I3, I 592. Thence they marched

1 As to the council of generals, see Gaiko-Shiko, p. 229.

2 For an account of the war preparations, see Transactions of the Asiatic Society of Japan, vol. vi, p. 235.

${ }^{3}$ In 1543 firearms were introduced by the Portuguese into Japan, where their manufacture soon developed. 
to Tongue, a neighboring castle of Fusan, and subdued the enemy after half a day's skirmish. General Kiyomasa and his corps shortly afterward landed in Korea and easily captured the strong fortress of Kegushagchiu. The whole country was now opened to the vast force of the invaders and they advanced toward the capital. The fall of TyungChiu, considered to be one of the strongest castles in the middle province, caused a great panic in the capital. On April 30 King Lien held a royal council, in which it was decided, on motion of the war minister, Yi-Sanha, that "the court should remove to Ping-Yang, the old capital," and the royal train set out from Seoul that night. ${ }^{1}$ Three days later, Seoul surrendered and was occupied by the Japanese army. At a conference with the Korean general, Ri Tokukei, General Konishi offered to spare Korea, if, even at that late day, a free passage to China should be given to the Japanese army. The negotiations, however, ended in failure. ${ }^{2}$ General Kato pushed on to the north and captured two Korean princes in the strong castle of Kaineifu. His demonstration was so formidable that he is known even to present-day Koreans as "Kishokwun"-the demon general. King Lien, alarmed by the approach of the Japanese army, on June 2 held a council ${ }^{3}$ and decided to abandon Ping-Yang, and to proceed north to Hang-Yung; but, finding there that Kato's soldiers had already overrun that district, he turned westward to $\mathrm{Wuji}$ on the frontier of China. The Japanese forces occupied Ping-Yang on June II, and determined to hold the city as their second headquarters.

Meanwhile, the Chinese governor of Loatung, a province adjacent to Korea, on the urgent appeal of King Lien, had

1 Korean Review, History of Korea, vol. ii, p. 472.

2 Transactions of the Asiatic Society of Japan, vol. vi, p. 240.

${ }^{3}$ Korean Review, History of Korea, vol. ii, p. 527. 
sent 5,000 men to Ping Yang in July. ${ }^{1}$ They were, however, defeated with wholesale slaughter. This disaster startled the Chinese court, which determined at once to send a large force to the aid of Korea. But, as time was required for preparation, the Chinese government sent an envoy, named Chin Weiking, who was to gain delay by pretending to enter into peace negotiations. ${ }^{2}$ Weiking, upon his arrival at Ping Yang, immediately entered into conference with General Konishi and succeeded in obtaining an armistice of fifty days. In return, he promised to proceed to Peking and come back to Ping Yang with an "arrangement for a peace satisfactory to both parties." As the result of this agreement, the Japanese troops had rather an idle time during the rest of the year, till Chin Weiking reappeared at Ping Yang, not with terms of peace, but with 40,000 soldiers under General Li-Jusong. ${ }^{3}$ The Japanese attacked them on January 6, I 593, but so large was the Chinese force that the Japanese were compelled to retire to Seoul in order to concentrate their divisions. After three months of hard fighting, both the Japanese and Chinese grew anxious for peace. Weiking came to the camp of General Konishi in April and proposed negotiations, and, as the Japanese forces were suffering from plague and famine, Konishi, in spite of Weiking's previous treachery, accepted the proposal and sent to the Taiko for instructions.

Hideyoshi drew up in June a basis of peace, consisting

1 Transactions of the Asiatic Society of Japan, vol. vi, p. 242.

2 Ibid., p. 243. Chin Weiking, a native of Chekiang and a man of talent and eloquence, was chosen for the mission probably for his knowledge of Japanese and for his ability in the "tricky" diplomacy which prevailed among the feudal kings of China in the age of military anarchy.

s Aston, "Hideyoshi's Invasion," Transactions of the Asiatic Society of Japan, vol. ix, part I, p. 87. 
of seven articles, and forwarded it to Konishi. ${ }^{1}$ After several conferences, it was accepted by the Chinese with a few modifications, and Weiking proceeded to Peking to obtain the sanction of the Celestial emperor. The principal provisions of the treaty were, first, the surrender of the two Korean princes captured by General Kato; second, the restoration of half the territory of Korea to the Korean king, the other half to be retained by Japan; third, the payment of an annual tribute to Japan; and fourth, the investing of Hideyoshi with the title of king. ${ }^{2}$ The Japanese understood that the fourth clause meant that Hideyoshi was to be invested with the title of king of China, and, being more accustomed to arms than to diplomacy, they did not forsee the opportunity which the silence of the article on this point would give to the crafty Weiking to pervert and evade the stipulation. After the conclusion of the treaty military operations ceased, and in the spring of I 594 Hideyoshi despatched Naito Nyo-an to obtain a definitive approval of the peace. Time passed and no report was received, and Hideyoshi, becoming impatient, declared that he would in person invade China with 300,000 soldiers, but he delayed action on the advice of General Asano. ${ }^{3}$ Meanwhile the cunning Weiking had advised the Chinese court that "Taiko Hideyoshi wanted to become king of Japan." The court at first doubted, but, being reassured by the precedent that Ashikago Yoshimitsu was once honored with the title of king, at last decided to act upon Weiking's view. ${ }^{4}$ The document of investiture and the insignia were prepared, and Fang Hsiang and Chin Weiking were commissioned, as ambassador and

1 For the text of the basis of the treaty, see Takekoshi, History of 2,500 Years, p. 552, in note.

2 Gaiko-Shiko, p. 274. The other three clauses being secret, are unknown.

3 Gaiko-Shiko, p. 275.

4 Supra, p. 69. 
vice-ambassador, to proceed to Japan to perform the ceremony. The embassy arrived in Japan in August, I596, with 300 horses and gold and silver as presents for Hideyoshi. The Taiko, confident that he was to be invested with the title of king of China, and adorning himself with the regalia which he had just received, gave the embassy a most elaborate audience at the Fushimi castle and directed the ambassador to read the investiture. When the ambassador came to the clause where it was stated that "We [the Chinese Emperor] do therefore specially invest you with the dignity of king of Japan," " the Taiko flew into a violent rage, and, seizing the document and throwing it on the floor, declared that he would become king of China and would teach the Chinese court how little it had to do with the sovereignty of Japan, which belonged exclusively to the imperial blood. Thus the transaction was ended, and Hideyoshi immediately issued an order for a second invasion.

The campaign began in February, 1597, and ended on September 15, 1598, when General Tokugawa, in accordance with Hideyoshi's wishes, instructed all the generals to withdraw from Korea. ${ }^{2}$ The last word of the great Taiko on his death-bed, was " not to let the Japanese soldiers turn to the ghosts in the foreign land."

As the Mongol had failed, so Hideyoshi failed to realize the idea of universalism after having wasted more than 260,000 human lives. ${ }^{3}$ On the other hand, the great hero

1 The translation of the full text of the document is given in Transactions of the Asiatic Society of Japan, vol. ix, p. 218.

2 For the account of the second invasion, see Griffis, The Hermit Nation, chaps. 18-19. For a more full and trustworthy account, see Shosen Monogatari (The Story of Korea), translated into German by Dr. Pfizmaier.

${ }^{3}$ For this estimate by Mr. Ogawuchi, see Griffis, The Hermit Nation, p. 144 . 
was unable to secure for his descendants even the administrative control of his own country; for, while he was engaged in the foreign wars, Tokugawa Iyeyasu usurped the power of the Hideyoshi family. His unsuccessful invasion of Korea would have resulted in fostering piracy in Asia by Japanese sailors who had been engaged in the naval struggle, had not armed vessels of the maritime nations of Europe appeared and had not Tokugawa prohibited the building of ocean-going vessels in the beginning of the seventeenth century. ${ }^{1}$

1 Nitobe, Intercourse between the United States and Japan, p. I4. "After I609, ships above a certain tonnage ( $500 \mathrm{Koku}=2,500$ bushels or $30,000 \mathrm{cu}$. $\mathrm{ft}$.) were not allowed to be built, the motive of this legislation being to cripple distant navigation." 


\section{CHAPTER IV}

The First Intercourse of Japan with European Nations, I 54 I-I 638

Intercourse with the Portuguese and Spaniards.-Although India and China had intercourse with the Greeks and the Romans in ancient, and with the Italians in medixval times, none of the western peoples set foot in the Island Empire of Japan until a wrecked Portuguese ship was brought thither by the Black Current in I54I. Japan and the Japanese were first described to Europe by Marco Polo, at the end of the thirteenth century, as

Chipangu, an island towards the east in the high seas, I,500 miles from the continent; and a very great island it is. The people are white, civilized, and well favored. They are idolaters, and are dependent on nobody, and I can tell you the quantity of gold they have is endless; for they find it in their own islands. ${ }^{1}$

His mention of gold may to some extent have stimulated the Portuguese and Spaniards to endeavor to open a new sea route to Asia in the fifteenth century. "Cipango" occupies a significant place to the east of Asia in Toscanelli's map, which was used by Columbus for his voyages, and the latter earnestly inquired for that island when he reached the archipelago of the West Indies. ${ }^{2}$

1 Yule, The Book of Sir Marco Polo (second edition), vol. ii, p. 235.

2 Hildreth, Japan as it Was and Is, p. 14. See also Murray, Japan, p. 2. In the map there is no American continent between "Cipango" 3II] 
The lucrative monopoly of Asiatic trade by the overland route, hitherto held by the Venetians, awakened jealousy on the part of the rival commercial nations on the Mediterranean, and the "gold land of Asia" became a watch-word among them. Portugal was the first to launch forth upon the ocean to discover a sea route to India. Pope Nicholas $\mathrm{V}$ by the Bull of $\mathrm{r} 45^{2}$ authorized the Portuguese king to "attack and subjugate all the countries of the infidels, to reduce all their inhabitants to slavery and to seize all their property." ${ }_{1}$ Two years later, rewarding the intention of Prince Henry to discover India by way of the African continent, the same Pope gave to the Portuguese sovereign the right to all the regions discovered and to be discovered " as far as the Indies." 2 Portugal thus acquired a monopoly of the privilege of colonizing and subjugating all the non-Christian world. Under the guidance of Prince Henry the Portuguese made repeated efforts to round the African continent, but in this they were not successful until Diaz in I 487 reached the southern point of the continent.

Meanwhile, Columbus, believing the earth to be round, hoped to reach the eastern coast of.India by sailing across the Atlantic, and applied to Dom João II of Portugal for permission to carry out his plan. The king was not disposed to countenance so vague a project. Applying then to Spain, through the influence of Queen Isabella of Castile, Columbus eventually received permission to fit out an expedition, and in 1492 discovered the New World. Thereupon the Spanish sovereigns asked the Pope for

and Europe. Columbus's aim was to discover "a route to this reputedly rich island and to the eastern shores of Asia."

1 As to the Bulls of 1452 and 1457 , see Harrisse, The Diplomatic History of America (1452-I493), p. 6.

2 Ibid. 
a grant of the newly discovered dominions. By the famous Bulls of partition, in May, I493, the newly discovered region was recognized as Spanish, and the unknown world was divided by an imaginary line (some leagues west of the Azores or the Cape Verde Islands) between Spain and Portugal. ${ }^{1} \quad$ Against this arrangement the Portuguese protested, and it was modified in the next year by the treaty of Tordesillas, between Spain and Portugal, which fixed the divisional line " at a distance of three hundred and seventy leagues west from the Cape Verde Islands." 2 Each nation then proceeded to exploit its respective sphere.

In 1498, Vasco de Gama, of Portugal, discovered the coveted sea route to India, and the Portuguese then began to swarm to the East. In I 5 Io they forcibly occupied Goa and established there a provincial government. In the following year they founded a naval station and commercial staff at Malacca. As early as ${ }^{5}{ }^{I} 6$, they sailed to the coasts of Siam, Burmah and southern China. In I5I7 Admiral Andrade effected a commercial arrangement with the governor of Canton. ${ }^{3} \quad \mathrm{He}$ also sent an ambassador to Nanking, the old Chinese capital, but the Portuguese representative was there cast into prison. The Portuguese, however, although they established a stronghold in the Spice Islands and maintained regular communication with China, did not attempt to cross the ocean to "Chipangu" mentioned by Marco Polo.

In I54I, certain Portuguese traders from Siam, while sailing for China in a junk, were driven by a typhoon out to sea, and reached the Jinguji bay of the Bungo province,

1 See chapter iii, "The Three Bulls of May, 1493," in Harisse, The Diplomatic History of America. The definite line of demarcation is still unknown.

2 Ibid., p. 78.

3 Major, Prince Henry the Navigator, p. 418. 
in Japan. According to the European account, their names were Antoine Mota, François Zeimoto and Antoine Pexota. ${ }^{1}$ By a number of historians, however, Fernando Mendez Pinto is regarded as the first European visitor to "Chipangu." This famous traveler was cast ashore on Tanegashima Island, off the province of Satsuma, in a shipwreck in I 543. The "queer looking persons" were questioned as to " where they came from" and "what they were." Fortunately, there was a Chinaman in the company, named Go How, who was able to answer, by writing in Chinese characters on the sandy beach: "This is a foreign ship from the Southwest [India, Cochin-China or Manila], come to trade with you." ${ }_{2}$ This primitive conference is said to have been the first ever held between Japanese and Europeans. Tokitaka, the governor-lord of the island, was much interested in the Portuguese and treated them with the utmost hospitality, and they made him a present of firearms, which had never before been seen by the natives. Pinto then visited the province of Bungo, from the lord of which he obtained permission to trade at the port of Hirato. ${ }^{3}$ The reports of these proceedings, detailed and exaggerated by the refugees, attracted eager attention among the Portuguese, both at home and abroad. Their merchants at Goa soon fitted out a number of vessels for Kagoshima, in Satsuma, and for Hirato. The account of Marco Polo of the gold of Chipangu did not prove to be altogether deceptive. The Portuguese found the trade with Japan so lucrative that they were encouraged to come year after year.

${ }^{1}$ Gaiko-Shiko, pp. 441 and 787. See also Charlevoix, Histoire $d u$ Japon, p. 38.

2 Gaiko-Shiko, p. 788. See also Nitobe, Intercourse between Japan and the United States, p. 8.

${ }^{3}$ Gaiko-Shiko, p. 789 . See the note. 
This was the epoch of feudal autonomy in Japanese history. Provincial barons, jealous of one another's military supremacy, were anxious to buy firearms. They were also very willing to spend their gold and silver, which had accumulated from generation to generation, for the new luxuries of Europe and India imported by the Portuguese. To foster foreign trade, the feudal barons of Kiushu willingly opened their ports. They granted to the Portuguese the privilege of traveling freely in the interior, and hospitably invited them to settle upon their lands, even offering to exempt them from "all kinds of taxation and duties." 1 Nagasaki was also opened to foreign trade, the Portuguese founding there a large settlement in $\mathrm{I}_{5} 66$. The promising commercial intercourse between Japan and Europe thus initiated was, however, eventually hampered by the religious propaganda of the Catholic missions.

Although the Portuguese opened up the Spice Islands by force and tried to gain admission to China by threats, they did not attempt forcibly to colonize or subjugate Japan, for the long distance from Goa, their central station, prevented them from employing military measures, and a warlike people like the Japanese were not likely to be subdued except by the mild means of religion. That " the missionary follows trade" was particularly true of the Portuguese in Japan. With the second visit of Pinto, Francis Xavier came to Koysshima in I 549 and introduced the work of the Jesuits. ${ }^{2}$ On his fourth visit, in 1556 , Pinto acted as ambassador from the Portuguese viceroy, Don Alonzo de Noronha, to the lord of Bungo, and brought with him "Father Gaspard Vilela, four brothers and five young orphans." 8

1 Kampfer, The History of Japan, book iv, chap. v, p. 3II. See also Suganuma, Dai-Nihon Shogyo-Shi (Commercial History of Japan), p. 305 .
${ }^{2}$ Hildreth, Japan as it Was and Is, pp. 47-49.
3 Ibid., p. 76. 
"The meek and comfortable doctrine of the Gospel" soon gained the hearts of the Japanese; the Jesuits spread throughout Kiushu; and it was estimated in $158 \mathrm{I}$ that the native Christians in the chief ports of the principal islands numbered as many as $150,000 .^{1}$ The lords of Arima, Bungo and Omura were not only converted to the alien creed, but in 1582 sent their ambassadors to Rome to pay homage to Pope Gregory XIII. ${ }^{2}$ Converting one by one the provincial lords who maintained their local autonomy, the Portuguese Jesuits would easily have subjugated the whole empire, had there been no central control over the feudal princes.

Nobunaga, though he brought about the unification of Japan, had no opportunity to deal with the new religion. Taiko Hideyoshi, however, Nobunaga's successor, assuming the whole administration, determined to suppress the foreign propaganda and took the first step through the edict of July, $1587 .^{3}$ By this edict the Jesuit missionaries were ordered to leave Japan. Merchants were not affected by it. Most of the converted lords in Kiushu, whom Hideyoshi had not yet absolutely subjugated, stood firm and protested against the banishment of the missionaries. The edict alarmed the colonial government of Goa, whose viceroy was sent on a special mission to Hideyoshi, with a letter asking him to continue the "favor" which had been shown to the the Portuguese in the past." After careful consideration,

${ }^{1}$ Heine, Japan, Beiträge zur Kenntniss des Landes und seiner Bewohner, p. 53.

2 For a full account of the Japanese embassy to Rome, and the text of the letter to the Pope, see Mr. Satow's paper, Transactions of the Asiatic Society of Japan, vol. xviii, part ii.

3 For the text of the edict, see Heine, Japan, p. 57.

4 For a copy of the letter, see Hildreth, Japan as it Was and Is, p. 105 . 
Hideyoshi on July 25, I592, gave an answer justifying the edict. ${ }^{1} \mathrm{He}$ was not blindly anti-European, for he did not propose to banish Portuguese who were merely engaged in trade; but he desired to exclude any foreign element which would menace the national existence. He aimed at nothing but "self-preservation," or nationalism, as his answer to the viceroy clearly pointed out:

As to what regards religion, Japan is the realm of the Kami, that is, of Sin, and the beginning of all things, and the good order of the government depends upon the exact observance of the ancient laws of which the Kami are the authors. They cannot be departed from without overturning the subordination which ought to exist, of subjects to their sovereign, wives to their husbands, children to their parents, vassals to their lords, and servants to their masters. These laws are necessary to maintain good order within and tranquillity without. The fathers, called the Company, have come to these islands to teach another religion; but as that of the Kami is too deeply rooted to be eradicated, this new law can only serve to introduce into Japan a diversity of worship very prejudicial to the state. It is on that account that, by an imperial edict, I have forbidden these strange doctors to continue to preach their doctrine. I have even ordered them to leave Japan, and I am determined not to allow anybody to come hither to retail new opinions.

Of commercial intercourse he spoke as follows:

But I still desire that commerce between you and me may continue on its old footing. I shall keep the way open to you by sea and land, by freeing the one from pirates and the other from robbers. The Portuguese may trade with my subjects in all security, and I shall take care that nobody harms them.

1 Hildreth, Japan as it Was and Is, p. Iro, for the full text of Hideyoshi's answer to the Portuguese viceroy. A copy of the original letter, in Japanese, is in Suganuma, The Commercial History of Japan, p. 329. 
Hideyoshi, however, was unable strictly to enforce his edict, being engaged in the invasion of Korea.

In the sixteenth century, the Spaniards little respected the sovereign rights of other nations. On the contrary, they entertained the idea of establishing a world-empire; and, in spite of the Bull of I493 and the treaty of Tordesillas, made every effort to destroy the colonial and commercial monopoly of the Portuguese in Asia. While they did not venture to cross the Portuguese sphere by way of the Cape of Good Hope, they came from another direction. Magellan, a native of Portugal who had become a Spaniard by naturalization, penetrated, in the course of his celebrated voyage, to the Philippines and the Moluccas by rounding Cape Horn. This encroachment on the Portuguese sphere was settled in I 529 by the treaty of Saragoça. Portugal recovered the Moluccas by paying to Spain the sum of 350,000 gold ducats, and a line of demarcation was drawn $17^{\circ}$ to the east of those islands. ${ }^{1}$ But this did not prevent the Spaniards from conquering the Philippine group, which lay well within the Portuguese sphere, as Zebu was captured by them in 1564 and Manila in $157 \mathrm{I}$.

Although Spanish ships from Mexico and the Philippines often touched at Japanese ports, their appearance was not officially recognized until a Spanish ship brought "black slaves" to Nobunaga. ${ }^{2}$ When Philip II seized upon the crown of Portugal, the Spaniards of Manila sought to arrogate to themselves all the privileges of the Portuguese as to commercial and missionary enterprises in Japan. Philip did not endorse this extreme claim, and the exclusive privi-

1 A full account of the Spanish and Portuguese rivalry is given in Satow's paper, Transactions of the Asiatic Society of Japan, vol. xviii, part ii, pp. 155 et seq.

2 Gaiko-Shiko, p. 577. 
leges of the Portuguese Jesuits were confirmed by the Bull of Pope Gregory XIII, in $1585 ;^{1}$ but the governor of Manila did not relinquish his projects. Hideyoshi demanded that the Manila government pay homage to Japan. ${ }^{2}$ This imperious demand the governor of course regarded as an insult to Spanish sovereignty; but he saw in it an opportunity both to gain access to Japan, and to deal a blow at the Portuguese monopoly. In I592, a Spanish envoy, Liano, appeared and had an audience with Hideyoshi, who, with his staff, was then at Nagoya, in Kiushu, preparing for the invasion of Korea. Liano bitterly complained of the Portuguese trade monopoly at Nagasaki, and charged the Portuguese with being engaged in a religious conspiracy to evade the recent edict. ${ }^{3}$ The result was that Hideyoshi instantly issued an order for the destruction of the Portuguese churches. The unscrupulous diplomacy of the Spanish envoy was not, however, altogether successful, since the Spaniards did not at once obtain the privilege either of trading or of preaching. Nevertheless, in the following year, another envoy came and secured a charter to trade at Port Sakai, making at the same time an oath not to bring any missionary. ${ }^{4}$ Thereafter the Spaniards came in large numbers to Japan, but their missionaries were more numerous than their traders and promptly engaged in strife with the Portuguese. This religious rivalry between the Jesuits and the Dominicans of the Latin nations, induced Hideyoshi and his successors to impose further restrictions upon them, and enabled the new-comers, the Dutch and the English, to enjoy the lion's share of the trade.

1 Satow, loc. cit., p. 156. Also Hildreth, Japan as it Was and Is, p. I 17.

2 Ibid., p. 108.

${ }^{3}$ Gaiko-Shiko, p. 791. See also Hildreth, op. cit., p. II4.

4 Gaiko-Shiko, p. 792. 
Intercourse with the Dutch and English.-It was chiefly England and Holland that checked Spain's scheme of universal empire in Europe; and it was their sailors and merchants who destroyed the colonial and commercial monopoly of Spain and Portugal in America and in Asia. While the Portuguese held the monopoly of the Asiatic trade in the sixteenth century, Dutch merchants made a fair profit by reselling in the north of Europe Asiatic merchandise which had been brought to Lisbon. The Spanish absorption of the Portuguese dominions in 1580 was soon followed by the brutal seizure of fifty Dutch ships at Lisbon, and by the forcible exclusion of Dutch merchants from trade with Portugal. The Dutch then began to cherish, more ardently than any other nation, the design of direct commerce with Asia. ${ }^{1}$

Several trading companies soon sprang up to promote ocean trade. At first the Dutch attempted to explore an independent route to the East by the Arctic seas; but, learning its difficulties they adopted the southern route and entered into direct competition with the Portuguese and the Spaniards. $^{2}$ Four vessels, fitted out in 1595 by the East India Company, an association of merchants of Amsterdam, sailed by way of the Cape of Good Hope to Java, where many hindrances were put in their way by the Portuguese. Information as to the Portuguese trade with Japan had already been furnished to the East India Company by VerVan Linschoten, who returned to Holland from the East in I592, and in I595 published his Reys-Gheschrift von de Navigation der Portugalaloyers in Orienten. ${ }^{3} \quad$ The first at-

${ }^{1}$ Cunningham, Western Civilization, vol. ii, p. I99. See also Hildreth, op. cit., p. 132 .

2 Cunningham, Western Civilization, vol. ii, p. 199.

${ }^{3}$ Nachod, Die Beziehungen der niederländischen ostindischen Kompagnic zu Japan im siebzehnten Jahrhundert, p. 91. 
tempt of the Dutch to enter Japan was made by a fleet under the command of Jacques Mahn, which left Holland on June 27, I598. He was instructed to make his way through the Straits of Magellan and across the Pacific. The fleet, however, became separated during a storm while off the Chilian coast. Some of the ships were wrecked; one was captured by the Spaniards. The "Liefde," the only survivor, conducted by William Adams, an English pilot, steered for Japan and arrived at Hirato in the middle of April, I600. ${ }^{1}$ In consequence of these misfortunes, which fell heavily upon small associations, and in order better to meet the severe competition of the Portuguese and the Spaniards, various Dutch companies, in 1602 , consolidated, for greater business efficiency, into a gigantic corporation, which acquired celebrity as the "Dutch East India Company," and which was authorized to make peace and war with the "Eastern Princes." ${ }_{2}$ Immediately after this consolidation, the Dutch successfully established themselves in India, Java and Formosa. In December, I607, a fleet composed of the ships "Roode Leeuw met Piulen" and "Griffoen," under Pieter Willemszoon Verhoeven, was despatched to Japan. It arrived at Hirato on the evening of June I, I609. The supercargoes left on July 27 for the court of the Shogun, at Suruga, bearing a letter to Iyeyasu from the Prince of Orange, and accompanied by Van Santvort as interpreter. ${ }^{3}$ They had no difficulty in obtaining permission to trade, to build residences and warehouses at any port or harbor where the Dutch merchants came, and to maintain "neighborly relations" with Japan. Iyeyasu

1 Nachod, Die Beziehungen der niederländischen ostindischen Kom- . pagnie zu Japan im siebzehnten Jahrhundert, pp. 95, 98, 99.

2 Raynal, India, vol. i, p. 166.

${ }^{3}$ Nachod, op. cit., pp. II2-II3. 
furnished them with a reply to the letter of the Prince of Orange, in which these privileges were guaranteed, together with a letter-patent for the free passage of the Dutch ships. ${ }^{1} \quad$ Under these favorable conditions the Dutch established their main trading-post at Hirato, where Jacques Specx was appointed as "Cape Merchant" to superintend their business, with three assistants, an interpreter and a boy. $^{2}$

The success of the Dutch was due largely to the personal influence of William Adams over Iyeyasu, who, impressed by Adams's frankness and straightforwardness, and his knowledge of mathematics and of ship-building, had permitted him to remain in Japan since I600. Iyeyasu confided in Adams's assurance that the "Dutch had no ambition beyond commercial relations." It is said that Adams was treated as " a lord of England," and that he enjoyed the "office of foreign adviser" at Iyeyasu's court.

As soon as the favorable answer of the Japanese ruler reached Amsterdam, another ship, the "Broch," was despatched, in I6I I, by the Dutch East India Company for the Japanese trade. Immediately after its arrival at Hirato, Specx proceeded to Yedo as the Dutch envoy to express the gratitude of the company for the privileges so generously granted by Iyeyasu two years before, and he brought with him presents of European products newly imported. ${ }^{3}$ Iyeyasu then gave Specx another letter-patent, which is, however, substantially the same as the one given in r6og. Its English translation runs as follows:

1 The German translation of the text of the reply is given in Nachod, $o p$. cit., appendix 5. An English translation is in Hildreth's Japan as it Was and Is, p. 143. A copy of the original Japanese letter is in Suganuma's The Commercial History of Japan, p. 562. For the text of the letter-patent, see appendix 6, in Nachod, op. cit.

2 Nachod, op. cit., pp. II4-II5.

3 Gaiko-Shiko, p. 795. 
All Dutch ships that come into our empire of Japan, whatever place or port they put into, we do hereby expressly command all and every one of our subjects not to molest them in any way, nor in any way to be a hindrance to them; but on the contrary, to show them all manner of help, favor and assistance. Every one shall beware to maintain the friendship in assurance of which we have been pleased to give our imperial word to those people; and every one shall take care that our commands and promises be inviolably kept. ${ }^{1}$

A Japanese record mentions, as the first appearance of an English ship, a vessel which anchored near the "Five Islands " of Hizen, in Japanese waters, as early as $\mathrm{I}_{554 .}{ }^{2}$ Another English ship, which arrived at Hirato in 1580 , obtained a permit to trade from Lord Matsu-ura. William Adams, who took up his residence in Japan in 1600 , though originally an English subject, was sworn to Dutch allegiance. But, although these incidents may have been in a sense preliminary, English intercourse with Japan did not assume a definite form until the arrival of Captain Saris, an agent of the East India Company, in I6r3. After the destruction of the Spanish armada, Elizabeth put forth every effort to make her colonial and commercial power as great as that of France and Spain. These efforts were not at first very successful, owing in part to anxiety to avoid a collision with the Spaniards. In I600, however, England, adopting the Dutch policy, entered upon a direct attack on the colonial empire of Spain, by chartering the East India Company. $^{3}$ In April, I602, the company entered into an agreement with George Waymouth, navigator, for a voyage by

${ }^{1}$ Kampfer, The History of Japan, book iv, p. 382. The German text is found in Nachod's work, p. 148, and the original Japanese text, in Suganuma's book, p. 509.

2 Gaiko-Shiko, p. 790.

${ }^{3}$ Seeley, The Growth of British Policy vol. i, pp. 29I-292. 
the "north-west" passage to Cathan (India), China, or Japan, but the scheme of Waymouth was not realized. ${ }^{1}$ Two years later Sir Edward Michelborne obtained a license to explore the Asiatic countries as far as Japan, by the route around the Cape of Good Hope. His voyage was prematurely ended by the killing of his pilot, John Davis, by Japanese pirates on the coast of the Malay peninsula. $^{2}$ On April 4, I6I I, the East India Company issued a commission for the exploration of Asia, by which Captain John Saris was appointed to command a fleet consisting of the "Clove," the "Hector" and the "Thomas," and by which he was specially instructed to proceed to Japan with the "Clove" from Bantam, and to consult, upon his arrival in Japan, with Adams, who lived at the Japanese court and enjoyed great favor. $^{3}$ The fleet sailed from England on April I6, I6II, with four royal letters addressed respectively to the Great Mogul of Surat, to the king of Bantam, to the lord of Hirato, and to Iyeyasu ("Ruler of Japan"). On January 14, I6r3, Captain Saris left Bantam for Japan with only the ship "Clove," and arrived at Hirato after a five-months sail. Through the assistance of the Lord Matsu-ura and Adams, he soon proceeded to the court at Suruga, where, on September 8, he was received in audience by the Shogun, Iyeyasu. Saris delivered to Iyeyasu a letter. ${ }^{4}$ from King James I, and presents of European products. Praising the glory of the Ruler of Japan, and explaining the objects of the English commissioner, the letter requested Iyeyasu to afford English subjects " securities

1 Satow, The Voyage of John Saris to Japan, introduction, p. iv.

2 Ibid., introduction, p. v.

${ }^{3}$ For the abstract of Saris's commission, see ibid., pp. $x$-xv.

4 Ibid., pp. lxxvi-lxxvii, English text. Suganuma, The Commercial History of Japan, p. 514. The Japanese translation was made with the help of Adams. 
and liberties of commerce" for the mutual benefit and friendship of both countries, and invited the Japanese merchants to come freely to England. Iyeyasu was very graciously, disposed towards a commissioner from Adams's country, and asked Captain Saris to state in writing what privileges he desired. ${ }^{1}$ Saris, with the help of Adams, who had a fair knowledge of Japanese, drew up a draft of a petition in Japanese characters and submitted it to the secretary of state, Honda Kodzake-no-suke. The petition was soon approved, and Saris received a letter-patent and an answer to King James on October $8 .^{2}$ By the letter-patent the following privileges were given to the English in the name of the governor of the East India Company:

I. Freedom of commerce and navigation in the ports of Japan.

II. Absolute exemption from tariff duties, import as well as export, and from transit duties.

III. All necessary relief and assistance to wrecked ships and persons, and necessary provision and accommodation during their stay and on their departure.

IV. Judicial control by the Cape Merchant (the head of the English factory) over the property of deceased English subjects and over all offences committed by English subjects-the Japanese law to have no effect upon their persons and their property.

V. An assurance that Japanese subjects would be required to fulfil their contracts of sale.

VI. A guarantee against official confiscation of English goods, and an assurance of payment for official purchases.

1 Riess, "History of Hirato," in Transactions of the Asiatic Society of Japan, vol. xxvi, p. 23.

2 The letter to King James is given in the Diary of Captain Saris, p. 137. The original text of the Japanese is in Suganuma's Commercial History of Japan, p. 515. As to the letter-patent, see the full text, ibid., p. 138, and the Japanese text, ibid., p. 518. 
VII. The supply of Japanese subjects to English navigators in case they should need men for service in the prosecution of their trade and navigation.

VIII. Permission to explore Yezo (the present Hokkaido), or any adjacent islands of the empire, without a further passport.

By the earnest assistance of Adams, Captain Saris thus succeeded in obtaining commercial privileges in Japan more liberal than any ever before given to foreigners. Uraga, near Yedo, was first suggested to the English commissioner as the place for the English factory; but Saris preferred Hirato, which afforded better accommodations for Europeans. ${ }^{1} \quad$ Before his departure, Saris held a council at Hirato on November 26, and it was resolved to establish the main factory there, its staff to consist of eight Englishmen, with Richard Cocks as "Cape Merchant."

Under the auspicious guarantees of the letter-patent, the English traders, like the Dutch, easily forced out the Portuguese monopoly. The English soon established branch houses at Yedo, Osaka, Fukui, Karatsu, Suruga, Hyogo, Sakai, Nagasaki, and other places. The death of the generous Shogun, Iyeyasu, in I6 I 5, however, was a severe blow to English commerce. Hidetada, the second Shogun, restricted their commercial privileges to the port of Hirato, on account of their alleged adhesion to the Catholic faith, the Dutch having informed him that the English representatives were of the same religious body as the Spanish and Portuguese, as shown by the marriage of King James to the Portuguese princess. $^{2}$ The strenuous efforts of Adams and Cocks

1 Satow, Diary of Captain John Saris, p. 136.

${ }^{2}$ Diary of Richard Cocks (I6I5-I622), vol. i, p. 191. See also GaikoShiko, p. 798. 
could not accomplish the restoration of the English privileges. The Teutonic nations, though they had co-operated with each other until they had crushed the world-monopoly of the Latin nations, now came themselves into serious conflict over the commercial supremacy in Asia. The claim by the Dutch of the monopoly of trade with the Spice Islands was the origin of their difficulties with England. Although the directors of the Dutch East India Company had instructed the governor at Bantam not to interfere with English traders, yet their collision was inevitable. A regular skirmish took place on November 22, I6I7. The Hollanders captured the "Attendance," an English ship, at the Moluccas, and brought her into Hirato. This news excited the English traders there, and it was unanimously resolved at their council to despatch Mr. Cocks to the Shogun government for redress for the "unlawful capture of an English ship." " The Shogun, Hidetada, refused to take cognizance of anything done outside of his own territory, ${ }^{2}$ it being his policy not to entangle himself in any foreign complication. The struggle between the English and the Dutch grew more and more intense, and, the English factory was often protected by the soldiers of the lord of Hirato against the violence of the Dutch sailors. Happily for the English traders a "treaty of defence" was on June 2, I6I9, concluded in London, by which it was agreed that the East India companies of the two nations should act as partners in the trade with the Spice Islands. ${ }^{3}$ At the same time the Dutch captains were instructed that prizes captured from the Spaniards and their adherents, in the waters near Japan, should be divided between the establishments of England

${ }^{1}$ Cocks's Diary, vol. ii, p. 63.

${ }^{2}$ Riess, loc. cit., p. $8 \mathrm{I}$.

8 Ibid., pp. 86-87. 
and Holland at Hirato. This arrangement, however, was of brief duration, as it was reported in Hirato on August 2, I622, by the "council of defence" that the Dutch had separated their shipping trade from the English. The massacre of Amboyna occurred in 1623 , and was followed by the exclusion of English traders from the Spice Islands. In the same year the British East India company decided in the council of Batavia, to withdraw from Japan. ${ }^{1}$ Nor was this decision strange, since English trade with Japan was practically ruined by the edict of 1616 , by which it was confined to Hirato.

The Diplomacy of the Tokugawa Shogunate.-After the death of the celebrated Hideyoshi, and the battle of Sakigahara, Iyeyasu Tokugawa brought all of Japan under his rule and in 1603 inaugurated the Tokugawa régime, establishing the Bakufu government in Suruga province. The second Shogun of the Tokugawa, Hidetada, transferred the Bakufu to Yedo which, for two centuries and a half, remained the seat of the Tokugawa government.

Iyeyasu appreciated the economic value of foreign intercourse and its effect upon the prosperity of the country more keenly than any of his predecessors in the central authority. He adopted the open-door policy, a policy based upon principles of peace and friendship and freedom of commerce with other nations. He especially sought to appease the Koreans, who deeply resented the terrible reverses inflicted upon them by Hideyoshi's invasion, and, acting through So Yoshitomo, the governor-lord of Tsushima, he repeatedly sent envoys to the Korean court, with a view to re-establish the friendly intercourse of former times. For a while his overtures were in vain, but at last he convinced Korea that

${ }^{1}$ Letter of recall of Mr. Cocks by the East India Company, in his Diary, vol. ii, pp. 340-344. 
Japan under his rule was totally different from the "Japan of Hideyoshi," and a Korean envoy was despatched to him with a royal letter and presents. ${ }^{1}$ The envoy was warmly received at Suruga, in 1607 , and two years later Lord So concluded with Korea a commercial treaty. ${ }^{2}$ But, although Korea thus accepted the amicable advances of Japan, China was not inclined to do so. Traders from southern China, however, often came to Nagasaki, and were treated in the same manner as Europeans. So anxious was Iyeyasu to restore commercial relations with China that he gave, in I610, a charter of "Shuin" to the Canton ships, in order to encourage their coming. Two years later he sent Honda as a commercial agent to the viceroy of Foukin, in order to obtain the "Kan-go" for Japanese ships. The provincial lords of Kiushu were ordered, in $\mathrm{I}_{6} \mathrm{I}_{3}$, to open all their ports to Chinese trade. ${ }^{3}$ European nations were treated with great liberality. The privileges granted to the Portuguese and the Spanish, which were curtailed by Hideyoshi, were restored by Iyeyasu. To the Spanish governor of the Philippines he once wrote a letter, expressing his intention to establish direct commercial intercourse between Japan and Mexico. ${ }^{4}$ He gave letters-patent to Spanish vessels in I608 and especially opened the port of Uraga, in the province of Sagami, to Spanish trade. ${ }^{5}$ Prior to the arrival of Verhoeven, with the Dutch fleet, in I609, a Spanish envoy, Don Rodrigo de Vivers, besought Iyeyasu, besides continuing commercial relations, to grant the royal protection to Spanish missionaries, but to deny rights of trade

${ }^{1}$ For the text of the letter, see Aston, Transactions of the Asiatic Society of Japan, vol. xi, p. I24.

2 The Japanese text of the treaty is given in Suganuma's Commercial History of Japan, p. 4I7.

${ }^{3}$ Gaiko-Shiko, p. 751.

4 Ibid., p. 793.

5 Suganuma, The Commercial History of Japan, p. 380. 
to the Dutch, who were denounced as "pirates and enemies of Spain." The first two requests were granted, but the request for the expulsion of the Dutch traders Iyeyasu pronounced " impossible." To the Dutch and the English, who fully respected the sovereign rights of Japan, who had not the slightest ambition to encroach upon her territory, and who confined themselves to commercial relations for mutual benefit, Iyeyasu granted most liberal privileges. As noted in the Dutch and English letters-patent, all the ports of the empire were opened to them, and, besides being exempt from the local jurisdiction and from taxes, they enjoyed the privilege of the coasting trade.

Nor did Iyeyasu omit to encourage natives to go abroad to trade. He had made a favorite of William Adams because the latter was an able ship-builder. It is said that the Japanese in Iyeyasu's time possessed ocean-going vessels "measuring as much as I 20 feet by 54 , fully rigged with three masts." The Shogun also adopted the plan of giving to merchant-ships a license called "Shuin," or a letter with a vermilion seal, which was originated by Hideyoshi, in order to distinguish them from piratical craft. Such licenses were granted to many Japanese vessels of Sakai, Uraga, Nagasaki and Yedo, and to foreign vessels as well. Under this protection, Japanese sailors freely navigated the coasts of South China, Java, Manila, Anam, Siam and Malacca, and as far as India. ${ }^{1}$ While the maritime nations of Europe were struggling with each other for colonial and commercial advantages, Iyeyasu not only opened his country to foreigners, without regard to nationality and race, but also encouraged his fellow-merchants to go abroad for " honest trade."

${ }^{1}$ See Satow, "Notes on the Intercourse between Japan and Siam in the Seventeenth Century," Transactions of the Asiatic Society of Japan, vol. xiii, p. 133 . 
But, while Iyeyasu was liberal to western nations in matters of commerce, he was not indulgent towards the religious enterprises of the Catholic nations. He made as clear a distinction between commerce and religion as had Hideyoshi. He believed that "foreign trade" made the country prosperous, but that "the foreign religion" menaced its "tranquillity." As to the latter, he made up his mind to watch and restrict, and to banish, if necessary. While he was occupied with his campaign against the feudal barons and the ex-generals of Hideyoshi, who had refused to recognize his supremacy, he forbore to act, but, as soon as he had suppressed this opposition, he gave a proof of his policy by issuing, in 1600 , an edict for the expulsion of the missionaries. This measure, however, he was compelled to withdraw "in consequence of the threatening attitude adopted by certain Christian nobles." 1 Even Hideyoshi, the great hero, had been unable to enforce his edicts of exclusion effectively, since his general, Konishi Ukinaga, was a chief supporter of the Christians, and the provincial lords of Kiushu often threatened him with civil war. With the exception therefore of certain minor restrictions, Iyeyasu left religious matters in statu quo till I6I2; and the Catholic missionaries, taking advantage of the opportunity, flocked to Japan in greater numbers than ever before. It is said that out of sixty-four provinces, there were only eight " in which Christianity had no footing." 2 The Franciscans were in Yedo and Uraga, the Jesuits in the provinces of Kyoto, Shikoku and Kiushu, and the Dominicans in Satsuma. But, from г6г2 to I6r4, several edicts were issued for the persecution and expulsion of the Franciscans and Jesuits

1 Gubbins, "Review of the Introduction of Christianity into China," Transactions of the Asiatic Society of Japan, vol. xi, p. I7.

2 Ibid., p. 20. 
and the destruction of their churches, while native converts were called upon to renounce the foreign religion. The Jesuit accounts attribute these anti-Christian measures to the intrigues of the Dutch and the English. ${ }^{1}$ Nevertheless, Iyeyasu did not restrict commercial privileges on account of religious difficulties.

The death of Iyeyasu, however, opened the way to new measures. Hidetada, the second Shogun, continued the anti-Catholic policy, and even pushed it a step further when he restricted English traders to Hirato, because they were "Catholic." 2 It was of course impossible to enforce antiCatholic measures in localities in which the provincial lord and Christian converts were predominant; but the policy, formulated by Iyeyasu, of weakening the feudal princes so as to secure control over them, was steadily pursued. In I623 Iyemitsu, a grandson of Iyeyasu, and a man of ability and determination, became the third incumbent of the Shogunate. He reduced the powers and estates of the most powerful lord, called "Tozama Daimio," to those of a second-rate baron, "F Yedo, who were suspected of smuggling in missionaries, were banished from the town. This was followed by the edict of I 624 by which "all ports of Japan were closed to the foreigners, except Hirato and Nagasaki, of ": which Hirato remained open to the Dutch and English, Nagasaki to the Portuguese, and both to the Chinese." 3 . A vigorous effort was made to hold in check the province of Kiushu, in which the foreign faith was still predominant; and Mizuno, lord of the province of Kawachi, was sent to Nagasaki to make a rigid search for Christian conspirators.

1 Charlevoix, Histoire du Japon, p. 214.

2 Supra; p. 94

${ }^{3}$ Hildreth, Japan as it Was and Is, p. I86. See also Charlevòix; Histoire du Japon, p. 244. 
At the same time, Matsukura Shigemasa, a determined opponent of the Christians, was appointed lord of the province of Hizen, in which lay Amakusa, the stronghold of the converts of the Jesuits. His tyrannical measures and the numerous anti-Christian edicts of the central government aroused hot indignation among the converts and produced, in 1637 , a terrible insurrection, known as the "Shimabara rebellion " or the "Amakusa war." Of this revolt, the Portuguese, who were in 1636 removed from Nagasaki proper to the outer harbor, called Deshima, were regarded as the chief instigators, and for this reason they were by the famous edict of 1638 ordered to leave Japan forever. By the same ediot, the Japanese were also prohibited from going abroad. So great is the historical interest of this measure that it should be quoted at length :

No Japanese ship nor boat whatever, nor any native of Japan, shall presume to go out of the country: whoever acts contrary to this shall die, and the ship with the crew and goods aboard shall be sequestered until further orders.

All persons who return from abroad shall be put to death. Whoever discovers a priest shall have a reward of 400 to 500 shuets of silver, and for every Christian in proportion.

All persons who propagate the doctrine of the Catholics, or bear this scandalous name, shall be imprisoned in the Omra, or common jail of the town.

The whole race of the Portuguese, with their mothers, nurses, and whatever belongs to them, shall be banished to Macao.

Whoever presumes to bring a letter from abroad, or to return after he hath been banished, shall die with all his family; also whoever presumes.to intercede for him shall be put to death. No nobleman nor any soldier shall be suffered to purchase anything of a foreigner. ${ }^{1}$

1 Kampfer, The History of Japan, pp. 318-319. See also Woolsey, 
The Dutch traders, who thoroughly understood Japanese prejudices and the traditional policy of the Tokugawa government, not only renounced the Christian faith, at least in appearance, but also furnished the Shogun much documentary evidence of the recent conspiracy of the Portuguese. In consequence the Dutch alone were allowed to trade in Japan, and their commercial agent (Cape Merchant) was authorized to furnish the government an annual report on foreign events. ${ }^{1}$ In I64I the Dutch merchants were ordered to reside only at Deshima, where they continued to enjoy a commercial monopoly until the reopening of Japan in $185^{8}$.

From what has been related it is evident that the Japanese were not originally "anti-European" or "anti-Christian," nor governed by " race-prejudice" or "hermit" propensities. On the contrary, they welcomed foreigners without regard to nationality, race or religion, and treated them with the greatest liberality, granting them freedom of commerce and religion and in addition the privilege of extra-territoriality. What their statesmen opposed was the religious activity of the Catholic nations, which endangered the existence of the "Land of the Rising Sun." It was for " the tranquillity of the country," that the "Christian nations" were forced to depart. That for which Japan contended was the development and preservation of the "national state," for which the Teutonic nations were also struggling at the same time in Europe. The idea of the national state, or nation, rising against emperor and Pope was the same in the Far East as in Europe. There is, however, a striking divergence between the paths by which in the Orient and

"History of Nagasaki," Transactions of the Asiatic Society of Japan, vol. 9, part ii, p. I25. The Japanese text is in Suganuma's Commercial History of Japan, p. 568.

1 Gaiko-Shiko, p. 802. 
in Europe the principle of national sovereignty was attained. In Europe, the Teutonic nations compelled the Catholic empires to recognize the Protestant states as sovereign equals, and laid the basis of the modern international society by the treaty of Westphalia in 1648 . In the Orient, Japan instituted by positive law ten years before the Peace of Westphalia, an "inclusive and exclusive" policy, and preserved her sovereignty by remaining isolated from the society of the West. 


\section{CHAPTER V}

Reopening of the Sealed Japan, i643-1868

Attempts to Reopen the Empire by European Powers.The policy of non-intercourse maintained by Japan would be justified from the national standpoint if it had been necessary to her existence; but, from the international point of view, the isolation of a nation from the rest of the world is opposed to the interests of mankind, and is considered inadmissible. European nations did not protest against Japan's edict of exclusion, nor did they attempt to reopen the country by force, for in the seventeenth and eighteenth centuries they possessed no adequate means of communication for such a purpose; but they neglected no opportunity to regain access to the hermit nation.

In 1643 , five years after the edict of exclusion, two Portuguese men-of-war arrived at Iwo Island, in Satsuma Bay, and besought the Daimio Shimazu to restore the former intercourse, apologizing for the religious abuses of the past; but they were not listened to. ${ }^{1}$ A like failure attended the visit of two Portuguese men-of-war to the harbor of Nagasaki, in I647..$^{2}$ In 1673, the English ship "Return" came to Nagasaki with a royal letter and demanded the renewal of commerce on the basis of the old agreement; but the governor answered in the negative, ${ }^{3}$

1 Gaiko-Shiko, p. 804.

2 Ibid., p. 153.

Ibid., p. 806. See also Hildreth, Japan as it Was and Is, p. 205. 104 
pointing to the marriage of Charles II to a daughter of the Catholic sovereign of Portugal, intercourse with whom was prohibited by the positive law of the empire.

France and Russia, though they had previously had no intercourse with the Japanese, made attempts to open the empire. In the reign of Louis XIV, Colbert, who had undertaken to restore the financial administration of France, founded the French East India Company and projected the establishment of commercial intercourse with Japan. As his agent for this purpose he chose Francis Caron, who had once served in the Dutch factory in Japan. Colbert was especially solicitious to avoid the political and religious entanglements into which the Portuguese had fallen. ${ }^{1}$ A letter $^{2}$ from Louis XIV to the emperor of Japan, and an instruction to Caron, were prepared in 1666 , but the project was not carried out. Russia was the first country to attempt to enter Japan from the North. Catherine II took advantage of the opportunity afforded by the sending home of a Japanese wreck by the governor of Siberia, Lieutenant Laxann. The governor arrived at Yezo in September, I 792, and asked the feudal lord of Matsumaye to enter into diplomatic and commercial relations. The latter answered in the negative, but suggested that commercial intercourse might be opened at Nagasaki, the only port to which foreigners were admitted. ${ }^{3}$ Lieutenant Laxann did not, however, proceed to Nagasaki. The Emperor Alexander. renewed the effort initiated by Catherine. Resanoff, a special envoy of the czar, landed at Nagasaki in I804, but after tedious conferences with the governor, was informed that " cet Empire entretenait des rapports avec beaucoup de na-

${ }^{1}$ Fraissinet, Le Japon, vol. ii, p. 5.

2 The letter is found in Hildreth, op. cit., p. $57 \mathrm{I}$.

s Ibid., p. 445. Also Gaiko-Shiko, p. 8I5. 
tions ; mais l'expérience a fait adopter le principe opposé." 1 During the first half of the nineteenth century, especially after the opium war in China, numerous attempts to open Japan were made by naval officers of England, France, Russia and the United States; but Japan did not listen to their demands till Commodore Perry appeared in Yedo Bay.

American Mission to Reopen Japan and Treaty Relations with Occidental States. - The United States had no intercourse with Japan in the eighteenth century, apart from the appearance of two ships in Japanese waters. ${ }^{2}$ It seems at one time to have been in contemplation to send thither Commodore Porter, who, in I8I5, addressed to Mr. Monroe, secretary of state, a letter concerning the country, but nothing was done. ${ }^{3}$ Subsequently, John Quincy Adams declared it to be "the right and even the duty of Christian nations to open the ports of Japan, and the duty of Japan to assent, on the ground that no nation has the right," any more than has a man, to withdraw "its private contribution to the welfare of the whole." 4 The appointment of Edmund Roberts by President Jackson, in $183^{2}$, as a special agent to negotiate treaties with the Asiatic nations, was the first official step taken by the United States toward such opening. ${ }^{5}$ Roberts died, however, before reaching Japan; and in 1845 Commodore Biddle was instructed, after conveying to China the ratified treaty of commerce and amity, con-

1 Fraissinet, Le Japon, vol. ii, p. 24.

2 The "Eliza" and "Franklin," though they were Dutch ships, came to Nagasaki in 1797 and 1799 , respectively, under the American flag and with American crews, in order to avoid capture by English cruisers. Hildreth, Japan as it Was and Is, pp. 446-447.

${ }^{3}$ Nitobe, The Intercourse between Japan and the United States, p. 34.

4 North American Review, vol. lxxxiii, p. 258.

5 Senate Doc., Ist session, 32d Congress, vol. ix, p. 63. Instructions of the secretary of state to Edmund Roberts. 
cluded in 1844 , to call and test the sentiments of the Japanese government. He was particularly cautioned not to " excite a hostile feeling, or a distrust of the United States." When he at length arrived, in 1848 , his advances were repulsed, and he withdrew. In the followith year Commodore Glynn, who had been sent to Japan to look into the case of certain wrecked American whalers, submitted to President Fillmore a report in which he strongly urged the necessity of opening the country. ${ }^{1}$

During Fillmore's administration, the subject of intercourse with Japan excited great interest. Of this interest, one of the main causes was the industrial and commercial growth of the Pacific coast. ${ }^{2}$ The discovery of gold in California, the increasing trade with China after the establishment of treaty relations, and the development of steam navigation, made the United States feel more and more the necessity of using Japanese harbors and obtaining Japanese coal. Hospitality and protection were also desired for shipwrecked whalers; and it was besides felt that to succeed in a task in which European powers had failed, would redound to the glory of the American republic. Moved by these considerations, the government of the United States determined to adopt vigorous measures. Commodore Aulick was directed to proceed to Japan with a naval force. He was intrusted with a letter from President Fillmore to the Emperor of Japan, accrediting him as an envoy, and was furnished with instructions by Daniel Webster, who was then secretary of state. His credentials and instructions bore date July 10, $185^{1 .}{ }^{3}$ His sailing, however, was delayed, and he was eventually replaced by Commodore

1 Senate Doc., ibid., pp. 74-78.

2 Murray, Japan, p. 3II.

Senate Doc., ibid., pp. $80-82$, for the text of the letter of the president to the Mikado and the instructions. 
Matthew C. Perry. Meanwhile, Mr. Webster had died, and had been succeeded as secretary of state by Edward Everett. The president's letter to the Emperor of Japan was modified and enlarged. ${ }^{1}$ It contained the following declaration: "I have no other object in sending him [Commodore Perry] to Japan, but to propose to your Imperial Majesty that the United States and Japan should live in friendship and commercial intercourse with each other." Perry was instructed to effect a permanent arrangement as to the treatment of shipwrecks; to obtain permission for American vessels to procure supplies and provisions; and to secure if possible the establishment of a coal depot and the privilege of trading at one or more ports. ${ }^{2}$ Commanding the steam frigate "Mississippi," and several other vessels, he sailed for Japan at the end of November, I 852, by way of the Cape of Good Hope.

The Tokugawa government was more than thrice forewarned by the Cape Merchant, the Dutch factory at Nagasaki, of the coming of the American expedition, ${ }^{3}$ but it paid so little attention to the report that the appearance of the "black ships" at the entrance of Yedo Bay on July 8, I853, caused intense surprise and embarrassment among the Japanese, sleeping in the "tranquil epoch of the Tokugawa régime." Commodore Perry, when asked by the governor of Uraga for the reasons of his coming, replied that " he had been sent on a friendly mission to Japan, with a letter from the President of the United States for the Emperor," and that he desired a personal interview

${ }^{1}$ Senate Doc., 2d session, 33d Congress, no. 34, p. 9.

${ }^{2}$ Ibid., p. 6. Letters from the department of state to that of the navy.

${ }^{3}$ For documents of warning by the Cape Merchant, see KaikokuKigen (The Origin of the Opening of the Country), compiled by the Department of the Imperial Household, vol. i, pp. 45-46, 55-58, and 63-66. 
with an official of the highest rank, in order to arrange for the formal presentation of the letter. ${ }^{1}$ The governor declared that the law of the land forbade any communication with a foreign country to be held elsewhere than at Nagasaki, through Dutch or Chinese agents, and that the squadron should proceed thither. Perry, however, refused to go and firmly insisted that, unless he was allowed to deliver the president's "friendly letter" either to "the Emperor of Japan or to his Secretary of Foreign Affairs" in person, he should "consider his country insulted." 2 The Yedo government, embarrassed by his determination and his " formidable black ships," appointed Toda, lord of Idzu, as a commissioner to receive the letter; and on July I4, credentials having been exchanged on the preceding day, ${ }^{3}$ the Japanese commissioner reluctantly received the president's letter at Kurihama, two miles from the town of Uraga, where a building was specially erected for the reception of the American envoy. The preliminaries were thus happily closed without a conflict; but an apprehension was felt by the Japanese that, if the country should be opened, a "war-like nation" might again appear as in the time of the Mongol invasion. Perry went away, announcing that he would return in the ensuing spring to Yedo Bay for an answer, ${ }^{4}$ and intending to augment his squadron with ships which were then employed in protecting American interests in China.

After Perry's departure, the Shogun government sent out a circular, accompanied with a translation ${ }^{5}$ of the president's

1 Senate Doc., 2d session, 33d Congress, no. 34, p. 46.

2 Ibid., p. 49.

${ }^{3}$ Ibid., p. 50. Text of credentials of the Japanese commissioner.

${ }^{4}$ Ibid., p. 54. For the Japanese account, see Kaikoku-Kigen, vol. i, p. 96 .

I Ibid., pp. 85-89. 
letter for the consideration of the feudal lords, in order to ascertain their preference as to the maintenance or abandonment of the exclusion law, the prosecution of war or the maintenance of peace. The daimios almost unanimously advised a policy of seclusion; the celebrated memorial of Prince Mito especially manifesting "the spirit of the times." ${ }_{1}$ While the whole nation was in confusion, Commodore Perry reappeared in the bay of Yedo on February I3, I854, with a formidable squadron of eight ships. Whatever the "fundamental law of the country" or public opinion might be, the statesmen actually attending to public affairs better understood what would be the result of their refusal to enter into the negotiation demanded by the United States, when Perry returned with the additional force. Lord Abe Masahira and the other chief officials of the Shogun government were keen enough to see that such a "traditional" policy could not be successfully maintained. They therefore decided to listen to Perry's demands. After repeated conferences and discussions, proposals and amendments, banquets and exchange of presents, a treaty containing twelve articles was finally signed and exchanged on the last day of March, I854. This was the first formal treaty ever concluded by Japan with an occidental state; but other nations hastened to obtain similar treaties. Rear Admiral

- Sir James Stirling, cruising in Pacific waters during the Crimean war, came to Nagasaki and demanded the conclusion of a convention for opening Japanese ports to English ships; it was signed on October I 5, I854. Admiral Pontia-

- tine negotiated a treaty for the settlement of boundaries and the opening of Japanese ports to Russian ships, which was concluded at Shimoda, February, 1855. The Netherlands,

1 Translated into English by Nitobe, The Intercourse between the United Statcs and Japan, pp. 49-50. 
though they had enjoyed a monopoly of trade at Nagasaki, concluded their first formal treaty in January, I $855 .{ }^{1 .}$ These treaties, however, were merely in the nature of preliminary arrangements for the opening of the country. They stipulated for access to the ports of Shimoda, Nagasaki and Hokodate, for the purpose of obtaining necessary provisions; for hospitality in case of shipwreck, and for shelter in case of distress. None of them was in the usual sense a treaty of amity and commerce. No provision was made for general trade and its regulation, nor for diplomatic relations, though the western powers were eventually to be allowed to be represented by a consul or commercial agent. Indeed, the Perry treaty was somewhat of a disappointment to the United States ; ${ }^{2}$ but, as it served as a preliminary to the opening of a country which had been tightly closed for more than two centuries, it should be regarded as a remarkable achievement.

The United States lost no time in completing what Perry had left unfinished. In August, I856, Townsend Harris was sent out as consul-general "to reside at Shimoda;" but, though officially only a consular officer, he was " clothed by his government with diplomatic powers." 3 He took with him as interpreter Hency C. J. Heusken, a native of Holland. ${ }^{4}$ Harris was a man of great tact and patience, and so thoroughly versed in oriental affairs that he knew how to gain the confidence of eastern princes. When he reached

1 The text of all these preliminary treaties is found in British and Foreign State Papers, and also in Treaties and Conventions between Japan and other Powers, compiled by the foreign office of Japan, I884.

2 Nitobe, The Intercourse between the United States and Japan, p. 6r.

3 Foster, American Diplomacy in the Orient, p. I74.

4 Harris took a Dutch gentleman for the reason that the Japanese officials who had to do with foreign intercourse understood that language. 
Japan, anti-foreign feeling was raging among individuals and officials, and a permanent residence at Simoda was at first denied him. For ten months he wrestled with the question of an audience with the Shogun, at Yedo, where he insisted on delivering the president's letter in person. ${ }^{1}$ He was repeatedly informed that the law of the land forbade the entry of any foreigner into that city, and that negotiations with foreign states should be conducted at Shimoda through the governor; but he quietly persisted and patiently urged his suit till at length, on September 25, I857, he was permitted to proceed to Yedo. Escorted on his journey by a " train numbering some three hundred and fifty persons," the "American ambassador" ${ }_{2}$ was received on December 7 , with elaborate ceremony, in the first audience granted to a foreign mission at the Shogun's court since the exclusion edict of 1638 . Harris presented a letter from the president, to the Shogun Iyesada, and, while assuring the latter of the president's good wishes, expressed appreciation of the honor bestowed on himself by the royal reception. The Shogun briefly responded: "Pleased with the letter sent with the ambassador from a far distant country, and likewise pleased with his discourse. Intercourse shall be continued forever." ${ }^{4}$ This rupture of the traditional usage of the Tokugawa government, which denied audience to a foreign embassy, was a great diplomatic victory for Harris.

After his reception, Harris concentrated his efforts upon the negotiation of a commercial treaty. In a conference

1 Griffis, Townsend Harris (Diary of Mr. Harris), pp. 16r-162.

2 In those days the Japanese did not distinguish between a diplomatic officer and a consul. Whoever came to Japan with a letter from a foreign ruler was called an "ambassador."

3 The "letter from the president" was the letter of credence; a Japanese translation is given in Kaikoku-Kigen, vol. i, p. 442.

4 Griffis, ibid., p. 229. 
on December $12,{ }^{1}$ at the residence of Hotta, lord of Bitchu, who was minister of foreign affairs, Harris explained the impossibility of an exclusive policy in the days of steam and commerce, and made known "the true and frank wishes" of the president of the United States for the establishment, by peaceful negotiation, of commercial intercourse not only between Japan and the United States, but also between Japan and all other countries, as well as for the establishment of diplomatic relations through a minister residing at the capital. He adverted to the example of China, and the forcible measures directed against her by England, France and Russia, with resulting or concomitant territorial encroachments and other complications, and intimated that, if those powers should open Japan by force, the results would be the same as in China. He further declared that the United States was different from Europe; that it did not aim at religious propagandism, as did the Spanish and Portuguese in Japan, nor participate in the territorial and commercial abuses which the European powers had perpetrated in China. He remarked, in conclusion, that "if Japan makes a treaty with the United States, all other foreign countries will make the same kind of a treaty, and Japan will be safe thereafter." Harris also explained to the minister how to raise state revenue by customs, and spoke of the willingness of the president to act as " mediator" and use his good offices "in case Japan may have

1 An interesting account of the conversations between Harris and Hotta upon the preliminary arrangements for the treaty negotiation is given in Forcign Relations of the United States, 1879, part i, pp. 624626. The Japanese version was obtained by the American legation at Tokyo from the successor of Prince Hotta, was translated by Mr. Thompson, and was reported by Mr. D. W. Stevens. The Japanese text is given in Kaikoku-Kigen, vol. ii, pp. 445-463. See also Griffis, op. cit., pp. 237-240. 
difficulty with other powers." On December 2I, in an interview $^{1}$ at Harris's hotel, the commissioners of foreign affairs inquired concerning the ceremonials and needs of a resident minister, his rights, duties and rank, and in what respect he differed from a consul. When Harris replied that all these things were regulated by "the law of nations," the commissioners curiously asked, "What is the law of nations?" Numerous questions were also put as to the opium trade in China, and as to foreign trade, the principles and practice of tariff and customs administration, and the procedure of treaty negotiations. The commissioners confessed that they were in the dark and as "children" in regard to these points, which he explained to "their full satisfaction." ${ }^{2}$ It has been remarked that Harris acted as "professor" to the Japanese commissioners on the elements of international law, diplomacy and political economy. By kind advice and tender treatment, seasoned with.polite menaces, he gained more and more the confidence of the Shogun government and finally induced it to enter into treaty negotiations on January 18,1858 , in spite of the opposition of the imperial court at Kyoto and the daimios. Conference after conference was held, the negotiations proceeding smoothly; and on the basis of the draft drawn by Harris, with slight modifications, a treaty of amity and commerce was concluded on February 9, $185^{8} .^{3}$

With regard to the ratification of the treaty, the Japanese requested a certain delay for "consultation with the daimios and for the Imperial sanction." Hitherto, the Bakufu, the Shogun government, had assumed the exclusive conduct of foreign affairs. The Bakufu had closed Japan at its own

1 An account of the second interview is given in Kaikoku-Kigen, vol. i, pp. 465-483. Also Griffis, op. cit., pp. 243-244.

2 Ibid., p. 244.

I Ibid., p. 285. 
pleasure, and would at its own pleasure re-open it. The preliminary treaties were concluded by the Bakufu government, in the name of Taicoon, ${ }^{1}$ without reference to the Mikado and the daimios. Historically, the treaty-making power (diplomatic power) was vested in the Shogun alone. ${ }^{2}$ Anti-foreign feeling and anti-Bakufu movements were now prevalent throughout the country, however, and public opinion censured the Bakufu policy. The Yedo government was no longer able to control the feudal lords, and it was decided to obtain the imperial sanction of the new treaty and also the daimios' consent, in order to share with them the responsibility. The majority of the daimios, of course, declined to give their approval. The imperial throne was then occupied by the Emperor Komei, father of the present Mikado. His court was opposed to opening the country, and he withheld his sanction, in spite of the fact that the Bakuf $u$ often despatched missions to Kioto to obtain it. ${ }^{3}$ On the other hand, Harris pressed for action, and declared that, unless the matter was disposed of, he "would proceed forthwith to Kyoto and arrange it himself." But a further complication presented itself. The Shogun Iyesada, whose health was precarious, had no son; and friction arose among the feudal lords of the Tokugawa families in regard to the selection of his heir. These difficulties, combined with the anti-foreign and anti-Shogun movements, produced a crisis in the affairs of the Shogunate. Amid the confusion,

${ }^{1}$ History of the Empire of Japan, p. 304. "In those days of the Ashikaga family it had been customary for the Shogun to assume the title of King of Japan in his communication with other sovereigns. The Tokugawa discontinued this, on the ground that it was an infraction of the imperial dignity, and adopted instead the title Taicoon, or Great Prince."

2 Ariga, Kokuko-Gaku, vol. i, p. I3I.

3 Kaikoku-Kigen, vol. iii, pp. 2279 et seq. 
Iyesada appointed Ii, lord of Hikone, a statesman of determination, as Kampaku (regent of the Shogun) and Tairo (prime minister), and invested him with the highest authority, in order to enable him to solve the critical questions at issue. ${ }^{1}$ Meanwhile, American and Russian men-ofwar came to Yedo Bay, and reported that the British and French squadrons, which had been engaged in hostilities with China, were sailing for Japan. Greatly worried over the delay attending the ratification of the treaty, Harris took advantage of this information to press the Shogunate to affix its signature; ${ }^{2}$ and Ii-Kamon, considering that further delay would bring upon Japan misfortunes similar to those of China, decided to assume the entire responsibility, and on July 29, I858, signed the treaty without the imperial sanction. $^{3}$ When the British, French, Russian and Dutch envoys sailed into Yedo Bay, escorted by formidable fleets, they found that the most laborious part of their task had already been accomplished. Treaties, like that with the United States, were soon concluded by England, France, the Netherlands and Russia. Harris gave his assistance and the services of his interpreter, Mr. Heusken, to Lord Elgin, viceroy of India, in the negotiation of the British treaty. ${ }^{4}$ The new agreements were called by the Japanese "the Ansei treaties," because they were negotiated in the Ansei era. The Ansei treaties made provision for diplomatic agents at the capital, and for consuls at all the open ports. The ports of Shimoda, Hokodate, Nagasaki, Kanaga wa, Nei-

${ }^{1}$ Shimada, Kaikoku-Shimatsu, p. I32.

2 Griffis, op. cit., p. 319 . In a letter to Prince Hotta, minister of foreign affairs, July 24 , "Mr. Harris, after epitomizing the news, urged the very great importance of having the treaty signed without the loss of a single day."

'Kaikoku-Shimatsu, p. 147.

- Griffis, op. cit., p. 322. 
gata and Hiogo were to be open for foreign trade and residence; Tokyo for foreign residence only, and Osaka for trade only. By these treaties the powers obtained the right to use their own coin in Japan and to exercise consular jurisdiction over their citizens. They also secured freedom of worship. The treaties imposed restrictions upon foreigners (except the diplomatic agents), so that they could neither travel into the interior of the empire without passports nor reside outside the foreign settlements. For purposes of trade, any article except opium was admitted according to the tariff regulations. The most-favored-nation provision was applied not only to commercial privileges but also to judicial concessions. The provisions above mentioned are common to the Ansei treaties with the five powers. The treaty with the United States contained the further stipulation that the president would act as "a friendly mediator," in case of a difference between Japan and "any European power." Later on, the Shogun government concluded treaties of amity and commerce with Prussia, Italy, Spain, Portugal, Denmark, Belgium, Switzerland, and Sweden and Norway. Treaties with AustriaHungary and Hawaii in 1871 , and with Peru in 1873 , were concluded by the imperial government; but their provisions were substantially based upon the Ansei treaties. ${ }^{1}$

The bringing of Japan into relations with the outer world must to a great extent be ascribed to the patient and sincere toil of the American envoy, Townsend Harris, and to the self-reliant determination of Ii-Kamon. The western nations were satisfied, and Japan was rescued from a grave national crisis.

1 The text of all these treaties may be found in the British and Foreign State Papers, and in the Treaties and Conventions between Japan and Other Powers, edition of 1884 . 
Restoration of the Imperial Sovereignty.-The course of Lord Ii-Kamon aroused the indignation of the imperial court and the loyal party, and excited the anti-foreign party. It was one of the proximate causes of the downfall of the Shogunate and of the ascendency of the imperial power. In reality it was the forerunner of the revolution of 1868 . But the ultimate cause of the imperial restoration had, for more than two centuries, been operating upon the Japanese mind. As has been shown, the Mikado was originally the supreme authority, the fundamental source of all the ruling powers. The imperial power was, in course of time, absorbed by the Soga family, and then restored by the Taika reformation. It was again usurped by the Fujiwara and Taira families, and was eventually overshadowed by the Shogun Yoritomo of the Minamoto family, leaving to the imperial court at Kyoto only religious and ceremonial affairs. The Minamoto, Hojo, Ashikago, Oda (Nobunaga), and Toyotomi (Hideyoshi) families successively occupied the Shogunate for centuries, and, after Iyeyasu Tokugawa became Shogun in 1603 , he and his descendants ruled all Japan until the imperial restoration of 1868 . Under the Tokugawa régime, as the result of excluding foreigners and checking the powers of the provincial daimios, the country for many generations enjoyed "absolute tranquillity," with no civil war and no foreign complications. The study of literature grew apace in the eighteenth century, and it was mainly this study that led to the destruction of the Shogunate and of the feudal system. ${ }^{1}$ Chinese literature, which was largely read, fully explains the doctrine of "imperial sovereignty" and of "centralization of administration" and makes clear the distinction between "emperor" and "vassal." With the abrogation of the law prohibiting the

1 Fukuchi, Bakufu-Subo-ron (Essay on the Ruin of the Bakufu), p. 8. 
importation of foreign books, Dutch works also found their way into Japan and infused the European theory of monarchy and its centralization into the native mind. ${ }^{1}$ Japanese ethics, philosophy, history and poetry, naturally lamenting the decline of the imperial power, reiterated the doctrine of Shintoism and emphasized the spirit of reverence for the Mikado. The verses of Moto-ori, Kamo, and Nida inspired nothing but loyalty to the "divine personage." Although Komon, lord of Mito, and Rai Sanyo ${ }^{2}$ were not so radical as Montesquieu and Rousseau, the influence of Dai-Nihon-Shi and Nihon-Gaishi upon the imperial restoration is comparable to the influence of Esprit des Lois and Du Contrat social upon the French Revolution. The renaissance of royalism was sooner or later to be transformed into a reformation. "Anti-Shogunism," however, did not openly burst forth until the Shogun government concluded the treaty with Commodore Perry. When Perry came to Japan, the anti-foreign feeling which had been excited by Japanese historians against the Spanish and Portuguese, was revived. The exclusion party, though some of them were friends of the Shogunate, began to attack its foreign policy. On the other hand, the loyal party, though not wholly anti-foreign, attacked the treaty in order to embarrass the Shogunate. And when, later, Tairo Ii signed the Ansei treaties without the imperial sanction, the loyal party and the exclusionists combined and openly directed their attacks against the Shogun's government.

In vain Tairo Ii sought to explain to the imperial court

1 Ibid., p. 14. The eighth Shogun, Yoshimune (1716-1745), abrogated the law prohibiting the importation of western books.

2 Prince Komon's work, Dai-Nihon-Shi (The History of Great Japan), was published in 1715, and Rai Sanyo's work, Nihon-Gaishi (History of Japan), in 1727 . 
and the daimios the emergency in which he had acted. ${ }^{1} \mathrm{He}$ was not listened to. On the contrary, a secret imperial rescript was issued to Lord Mito, who, though he belonged to the Tokugawa clan, was yet the champion of the exclusionists at Yedo, to advise the Shogun government to expel foreigners from the country. ${ }^{2}$ Convinced that this advice could not be followed without a dangerous collision with the treaty powers, Tairo Ii adopted a decisive measure. Lord Mito was not only compelled to leave Yedo, but was also confined to his private palace in his own province. Many other daimios and officials who had advised Tairo to adopt anti-foreign measures, were deposed from their offices; and there followed the wholesale imprisonment of the "Samurai," who were suspected of inciting the antiforeign agitation. This arbitrary proceeding, known as the "Ansei Imprisonment," excited the anti-foreign party and the loyalists as well, and the members of the Mito clan were especially indignant. Tairo Ii-Kamon was, on March 23, I860, assassinated by one of the Mito Samurai while en route to the palace of the Shogun government. But the killing of Tairo did not end the anti-Shogun agitation, nor did the proposed marriage of the new Shogun, Iyemochi, to the sister of the emperor, restore harmony between the courts of Yedo and Kyoto.

On the contrary, the Ronin (agitators) of the antiShogun clans, partly to further the exclusion policy, but chiefly to increase the embarrassment of the Yedo government, began to attack the foreigners as soon as the diplomatic agents and merchants of the treaty powers appeared at the capital and at the treaty ports. On January I4, I86r,

1 Shimada, Kaikoku-Shimatsu, pp. 154 et seq., for the text of the explanations given to the imperial court and the daimios.

2 Satow, Translation of the Kinsei Shiriaku, p. II, for the text of the English translation of the imperial rescript. 
Mr. Heusken, the secretary and interpreter of the American legation, was, while on his way home from the Prussian legation, assassinated, because he was regarded as one of the conspicuous promoters of foreign intercourse. Through Harris's efforts, an indemnity of $\$ 10,000$ was paid to his mother, who was then living at Amsterdam, in Holland. ${ }^{1}$ Six months later, the British legation was attacked at night and several guards were mortally wounded; a second attack was made on June 26, 1862. Subsequently, the sum of $£_{10,000}$ was paid to the families of the murdered guards. ${ }^{2}$ Three months later there occurred one of the celebrated cases of assaults upon foreigners, popularly known as the "Tokaido case." An English merchant, named Richardson, who, while riding on the Tokaido highway, crossed the train of Lord Shimazu, of Satsuma, who was on his way from Yedo to Kyoto, was attacked and slain by his lordship's retainers. ${ }^{3}$ Though the case was not so significant as the attempt upon the diplomatic agents, the British minister demanded the large indemnity of $\$ 500,000$ from the Shogun government, and \$125,000 from the daimio. ${ }^{4}$ The Yedo government soon paid the sum demanded of it, but the lord of Satsuma did not yield until his capital, Kagoshima, was bombarded by a British squadron, in August, 1863. On the night of May 24, I863, the American legation was mysteriously burned. The cause of the fire was long unknown, but the case was finally settled by the payment of $\$ 10,000 .^{5}$ Assault by Ronin on foreign legations and individuals became so prevalent in Yedo that all the legations of the

1 U. S. Dip. Cor. (1862), part ii, p. 806.

2 Adams, History of Japan, vol. i, pp. 168 et seq.

3 Under the feudal régime it was lawful to punish one who crossed the train of a daimio.

4 U. S. Dip. Cor. (1863), part ii, p. ro7r.

I Ibid., p. I097. 
treaty powers finally removed to Yokohama, where their naval forces were stationed.

Meanwhile, the Samurai, Ronin, and students of the loyalist clans, came secretly to Kyoto and submitted a project for the overthrow of the Shogunate. The daimios Mori, of Choshu, and Shimazu, of Satsuma, were regarded as the most enthusiastic of the loyalists. It is said that secret commissions from the emperor were given to them. ${ }^{1}$ The imperial court, backed now by the consuls of these strong daimios, in July, I862 despatched an envoy, Ohara, to the Shogun, demanding his presence at Kyoto to give information concerning the question of foreign exclusion. ${ }^{2}$ After much hesitation, the Shogun, Iyemochi, on June I5, I863, repaired to Kyoto. This was the first instance of the Shogun being summoned to the imperial court in order to confer upon the affairs of the country. A conference was held between the daimios and the court nobles; and an imperial exclusion edict was issued and entrusted to the Shogun for execution. On June 24, 1863, the foreign representatives were informed by Prince Ogasawara, minister of foreign affairs of the Shogunate, that he had been directed by the Shogun, following imperial orders, to close all ports and to remove foreigners on the ground that the people of the country did not desire intercourse with foreign countries. ${ }^{3}$ This intimation all the diplomatic representatives promptly repelled. The American minister, Mr. Pruyn, replied in strong terms that, if such a measure were determined upon and carried into effect by the Mikado and Taicoon, it "must

1 History of the Empire of Japan, p. 356.

${ }^{2}$ For the full text of the imperial message to the Shogun, see Kaikoku-Kigen, vol. iii, p. 2416 .

3 Dip. Cor. (1863), part ii, p. 1120 , note to the American minister. A similar note to the English minister, in the Japanese text, is given in Kaikoku-Kigen, vol. iii, p. 2505. 
involve Japan in a war with all the treaty powers;" and a similar protest was made by the French and English ministers. ${ }^{1}$ While the Shogun's government was thus caught between the pressure of the imperial court and the protests of the foreign representatives, Prince Mori, the daimio of Choshu, took steps to execute the exclusion edict by closing the strait of Shimonoseki; and in June and July, 1863 the "Pembroke," an American merchant steamer, the French Gunboat "Kienchang," and the Dutch warship "Medusa," were fired upon from the adjacent batteries. These attacks were answered in September, I864, by the bombardment of Shimonoseki by the allied forces of Great Britain, France, Holland and the United States. The daimio of Choshu yielded and pledged himself to grant free passage to foreign ships, and to make indemnity to the amount of $\$ 3,000$,ooo, which the Shogun's government subsequently agreed to pay. ${ }^{2} \quad$ Notwithstanding these attacks upon foreigners, the policy of the United States toward Japan was so generously and so wisely conducted by Secretary Seward, on the basis of accepting " no exclusive advantage," but of acting in cooperation with the other treaty powers, that Japan was led to look with favor upon the western civilization. ${ }^{3}$

The representatives of the treaty powers gradually became conscious that the treaties negotiated with the Shogun's government would not be respected by the Japanese, unless they were sanctioned by the imperial sovereign."

${ }^{1}$ Dip. Cor. (1863), pp. 1121-24.

2 See the convention for the payment of the Shimonoseki indemnities, concluded on Oct. 22, 1864. The United States, however, refunded a part of its share to Japan, by the act of Feb. 22, 1883. For details of the Shimonoseki affair, see Nitobe's The Intercourse between the United States and Japan, pp. 86-88.

3 Dip. Cor. (1862), part ii, p. 818; ibid. (1863), part ii, pp. 1037-39; and ibid. (1864), part ii, p. 594.

4 Ibid. (1863), p. II 25. 
When therefore the Shogun was again summoned to Kyoto to confer with the Mikado upon public concerns, and for that purpose was occupying Osaka castle, the foreign representatives caused their naval forces to be mobilized nearby, at Hyogo, in order to induce him to obtain imperial approval. Thus menaced, he humbly sued for the imperial sanction and at the same time tendered to the emperor his resignation from office, thus assuming personal responsibility for his mal-administration. The foreign policy of the imperial court, however, had already been greatly modified, owing to the fact that its counselors, the lords of Satsuma and Choshu, had, by the forcible exaction from them of the recent indemnities, been made to feel the superior energy of the western civilization. The Mikado did not accept the Shogun's resignation, but gave his sanction to the treaties on October 23 , $1865 .{ }^{1}$

Anti-foreign agitation ceased with the imperial approval of the Ansei treaties, but the anti-Shogun movement still continued. The Choshu clan was openly hostile to the Yedo government, while the Satsuma clan sought to reconcile the courts of Kyoto and Yedo. In reality, these two clans were competitors for supremacy at Kyoto; but many men of both perceived that in the co-operation of the two great clans lay the only hope of unifying and consolidating the empire. Foremost among these far-seeing statesmen were Saigo Takamori, of Satsuma, and Kito Koin, of Choshu, who were strongly convinced that dual government had become impossible and that the only solution of existing difficulties lay in the overthrow of the Shogunate. After frequent interviews, they finally drew up the "alliance" of the two powerful clans. Meanwhile, the Shogun Iyemochi died in September, 1866, and was succeeded by his regent,

${ }^{1}$ Dip. Cor. (1866), p. 194. 
Hitotaubashi Keiki. A few months later, on February 3, I867, the Emperor Komei also died of smallpox. The Crown Prince Mutsuhito, then in his fifteenth year, ascended the throne, and is now the reigning emperor, the one hundred and twenty-first of the imperial line. When the new Shogun assumed office, he found that his government was powerless. It possessed no control over the provincial daimios; its officials were no longer able to manage the complex domestic and foreign relations; and even the Shogun's further tenure of his own office had become doubtful. Lord Yamanouchi, the daimio of Tosa, one of the loyal party, frankly advised the Shogun to "restore the governing power into the hands of the sovereign and so lay a foundation upon which Japan may take its stand as the equal of other countries." 1 Deeply impressed with this timely advice, the Shogun drew up a document addressed to his vassals, asking their opinion of the advisability of his resignation. He declared:

It appears to me that the laws cannot be maintained in face of the daily extension of our foreign relations, unless the government be conducted by one head, and I propose, therefore, to surrender the whole governing power into the hands of the imperial court. This is the best I can do for the interests of the Empire. ${ }^{2}$

As there was no open opposition on the part of his vassals, the Shogun, on November 19, 1867, offered to restore his power to the Mikado. This surrender was graciously accepted by the emperor, and the imperial guards, composed

1 Kaikoku-Kigen, vol. iii, p. 2925, contains the Japanese text. The English translation is in Satow's Kensei-Shiriaku, p. 79.

2 The text of this document may be found in Horei-Zensho (annual series of laws and ordinances of the imperial government), vol. of 1868 . For the English translation, see Kensei-Shiriaku, p. 80. 
of troops of the Aizu clan, under the direction of the Shogun, were replaced by those of Satsuma, Tosa, Choshu, etc. The imperial government was organized by the Kuke princes (imperial princes), under the presidency of Prince Arisugawa. Prince Higashi Kuze was despatched to Yedo, and on February 8, 1868, he formally notified the foreign representatives that the supreme power had been restored to the Mikado and that the "title of Emperor should be substituted for that of Tycoon, which has been hitherto employed in the treaties." 1 This radical transformation was effected without a struggle with the pro-Shogunate daimios. The Shogun, however, desired to retain the post of "Lord Keeper of the Privy Seal" (Nai-dai-jin), but he was privately instructed to resign the office and to surrender the greater part of "the provinces hitherto forming his fief." 2 Moreover, the forcible procedures of the Satsuma and Choshu clans aroused the indignation of the lords of Aizu and Kuwana, the family daimios of the Shogun, which finally resulted in the battles of Fushimi and Toba. The Shogun, who was then in Osaka, retired to Yedo by sea, accompanied by the forces of Aizu and Kuwana. The foreign representatives were informed on February 14, I868, by the imperial government, that Keiki, ex-Shogun, and the lords of Kuwana and Aizu were in revolt, and were requested to maintain strict neutrality. ${ }^{3}$ The representatives duly recognized the existence of hostility and maintained neutrality. ${ }^{4}$ The ex-Shogun's party, in May, 1868, surrendered to the imperial forces at the battle of Yedo, and all the governing powers which had been usurped by the Shogun since the day of

1 Dip. Cor. (1868), part i, p. 659.

2 Fukuchi, Bakufu-Subo-ron, p. 323.

- Dip. Cor. (1868), no. 18, p. 672. 4 Ibid., vol. i, pp. 673-675. 
Yoritomo (II86) were completely restored to the emperor, while the seat of the imperial court was removed to Yedo, the name of which was changed to Tokyo (the eastern capital). The reorganization and reformation of the administration and of the army and navy, were continued. These revolutionary events, dating from the conclusion of the Harris treaty in 1858 , have been termed Osei-Fukko, or the imperial restoration.

The new imperial régime was by no means the "Asiatic paganism" prevalent during the old Shogun régime. The new government was not absolute and exclusive, as was the old military and feudal system. On April 6, 1868, when the emperor was still in Kyoto, he took a solemn oath of five items, ${ }^{1}$ in the presence of the imperial princes and daimios, which is regarded as one of the germs of the modern constitutional law of Japan. In this charter oath he manifested his eagerness to adopt western civilization. It declared that a deliberative assembly should be established, that all state affairs should be decided by public opinion, and that justice and impartiality should be the basis of the laws, without prejudice to ancient customs. As the first step under the charter oath, the Kogisho (public assembly) was established in December, ${ }^{2}$ the members being representatives of the clans, appointed by the daimios. Its chief function was to give advice to the imperial government. In I 87 I the clanship system of the daimios was abolished, and the system of prefectures, with governors, established in its place. $^{3}$ The Genroin ${ }^{4}$ (senate of elders) was established in 1875 , as an advisory and legislative body. Its members were appointed by the emperor. By the succeeding laws and ordinances, "feudal prerogatives," family

1 Horei-Zcnsho (1868), p. 64.

Ibid. (1871), p. 284.
2 Ibid.

Ibid. (1875), p. 18. 
privileges, estates and serfdom were all abolished. Every individual came to participate in the public service according to qualifications prescribed by law. Numerous statutes secured the rights of the individual, so far as his person and property were concerned. In short, all Japanese are equal before the law, and every Japanese subject, official or individual, owes direct allegiance to the emperor.

The modern constitution of Japan, which was promulgated twenty-one years after the restoration, in 1889 , is nothing more than "a subtle organism," the outgrowth of the political history of Japan. ${ }^{1}$ It was, however, framed in the legal forms of western jurisprudence, the constitutions of the German states (not the constitution of the German Empire) having been especially followed. According to the Japanese constitution, the rights of sovereignty belong exclusively to the emperor, who inherited them from his "Imperial Ancestor;" he himself is the constitution maker. ${ }^{2}$ It is said that " the amending clause" in " a complete constitution" is a test of the sovereignty or organization of the state. ${ }^{8}$ In amending the Japanese constitution, the emperor alone has the initiatory power, but he must obtain the consent of two-thirds of the legislative body, which, however, cannot modify his original draft. So far as the amending clause is concerned, the sovereign power is limited. It seems that the Japanese constitution has, as to the sovereignty, adopted a confused theory of certain German publicists, who "see danger to individual liberty in recognizing an unlimited power in the government; and" who "immediately conclude that the same danger exists

1 Ariga, Kokuho-gaku, vol. I, pp. 140-16r. This author's historical account of the Japanese constitution is most comprehensive.

2 See imperial speech on the promulgation of the constitution, and arts. I and 4. See also S. Hozumi, op. cit., pp. 36-39.

${ }^{3}$ Burgess, op. cit., vol. i, p. 137. 
if the sovereignty of the state be recognized." 1 But sovereignty in the constitution, instead of antagonizing, protects individual liberty. The power of sovereignty, in making or amending a constitution, should be absolute and unlimited, since it operates not only as an initiative and preventive, but creates positively whatever it wishes. The theory of unlimited sovereignty has been maintained by progressive publicists, like Professors Burgess, Laband, Goodnow, and Hozumi. ${ }^{2}$ Whatever the theory of sovereignty may be, the emperor alone has this supreme power in Japan. $\mathrm{He}$ also possesses all governmental powers, legislative, administrative and judicial, but exercises them with "self-limitations" according to the constitutional provisions. For example, the "civil liberty" of the people is constitutionally guaranteed against governmental encroachment; " every law" and "the expenditure of funds and the raising of revenue of the state" require "the consent of the imperial Diet;" "the imposition of a new tax or the modification of the rate shall be determined by law." 3 In the exercise of administrative power, the emperor obtains the advice of the cabinet ministers and the privy council, and the ministers are responsible to the emperor." Moreover, he obtains "the counter-signature of a minister" for all laws and imperial ordinances. Though "the judicature shall be exercised by the courts of law according to law, in the name of the emperor," the courts of justice are independent of the executive, and are organized under a law enacted by the legisla-

${ }^{1}$ Burgess, Political Science and Comparative Constitutional Law, vol. i, p. 57 .

2 Ibid., pp. 53-56. Laband, Staatsrecht des deutschen Reichs. Goodnow, Political Science Quarterly, vol. iv, p. 702. Hozumi, Kenpo-tai, pp. 15-18.

- As to individual liberty, see the articles of chapter ii of the Constitutional Provisions of Japan. Also, articles 5, 37, 62, 64 .

- Constitution of Japan, articles 55 and 56. 
ture, not under imperial ordinances or any other administrative decree. ${ }^{1}$ Like continental Europe, Japan has a special administrative court, which is independent of the ordinary courts of law; yet it is an effective institution for the remedy of executive abuses. ${ }^{2}$ As to foreign affairs, the emperor alone "declares war, makes peace, and concludes treaties," despatches and receives diplomatic agents, with the assistance of the cabinet ministers, without consulting the imperial diet. $^{3}$ In the matter of concluding treaties and conventions with foreign countries, the Sumitsuin (the Privy Council) may be consulted by the emperor." The present Japanese legislature, like those in occidental countries, is in structure based on the "bicameral system," consisting of the Kizokuin (the House of Peers) and the Shugiin (the House of Representatives); but it has no powers other than those enumerated in the constitutional provisions, nor any power to control the executive, as the cabinet is quite independent. ${ }^{5}$ In the matter of local government, regulations as to prefects, districts and communes were enacted in 1878 , and prefectural assemblies were established in the same year. ${ }^{\circ}$ About ten years later, in 1889 ,

1 Constitution of Japan, arts. 57 and 58.

2 Ibid., art. 6r. As to the law relating to the organization, jurisdiction and procedure of the administrative court, see Horei-Zensho ( 1890$)$, vol. vi, law no. 48. For general account, and principles of the administrative courts in France and Germany, see Goodnow, Comparative Administration, vol. ii, pp. 217-256.

${ }^{3}$ Constitution of Japan, art. I3. See also Count Ito, Teikoku-KenpoKaigi, pp. 25 et seq.

4 Imperial ordinance (1888), no. 22, art. vi; see also its amendment in Imperial ordinance ( 1890 ), no. 26.

- Constitution of Japan, arts. of chap. iii. The law relating to the Imperial Diet is found in Horei-Zensho (1889), vol. 2, laws nos. 2-3. Burgess, Political Science and Comparative Constitutional Law, vol. ii, pp. 106 ct seq. Hozumi, Kenpo-Tai, pp. 53 and 62.

'Horei-Zensho (1878), pp. 10 et seq. 
a law providing for local self-government for cities, towns and villages was enacted, which was very comprehensive in its scope. The law concerning prefectures was re-enacted in an amplified form in 1899 . By a law of the same year the several districts within the prefectures were endowed with powers of local self-government, and district diets were instituted. The Japanese system of local government, however, like the French and the Prussian, but unlike the American, is somewhat controlled by the central administrative authorities in order to prevent unwise conduct on the part of the localities, although there is very little interference on the part of the central legislature. ${ }^{1}$

In organization and in power the Japanese administration is very strong and effective, and in fact may be termed bureaucratic. On the other hand, the leglislature is still in its infancy, and the security for individual rights as against acts of government is still inadequate. Japan should learn more from the Occident, especially from the English-speaking countries, concerning the ample guarantee of individual rights, and the adequate but sober participation by the legislature in the exercise of governmental power, in order fully to develop the political, economic and social activities of the people.

In a word, the empire of Japan is a monarchial sovereignty, in the form of a state having a constitutional government, with a cabinet responsible to the emperor, a popular legislature and independent courts of justice, and with a centralized administration modified by local self-government.

1 For the law of local government of city, town or village, see Law (1888), no. I ; for those of the prefect and district, Law (1899), nos. 64 and 65. For a treatment of Japanese local self-government, see $\mathrm{Mr}$. Clement's paper in the Political Science Quarterly, vol. 7. See also Goodnow, Comparative Administrative Lave, vol. i, p. 336; and his Municipal Home Rule. 


\section{CHAPTER VI}

Japan's Entry into the Comity of Nations, i868-i 899

Consular Jurisdiction and Tariff Questions under the old Treatics. - When the western nations entered into treaty relations with Japan, they secured judicial functions for their consuls. Ordinarily, consuls are concerned principally with matters of commerce, but in certain countries, mostly in the Orient, they exercise an extensive jurisdiction over their fellow-countrymen. It is true indeed that in early times, under the system of "personal law" that then prevailed, consuls, even in Christendom, exercised judicial powers; ${ }^{1}$ but, with the growth of the idea of nationality and territorial sovereignty, and the fair application of municipal law to citizens and aliens alike, the judicial powers of consuls declined and were for the most part done away with. ${ }^{2}$ In oriental countries, however, they still retain such powers, the reason assigned being that the legal and moral standards of the Orient are materially different from those of countries of European civilization. Besides, oriental nations have been content rather to allow foreigners to be controlled by their own law than to assert jurisdiction over them. ${ }^{3}$ The Chinese, however, persistently maintained

1 Warden, The Origin, Nature, Progress and Influence of Consular Establishments, chap. iv. See also Savigny, Private International Law, pp. 15, 16 and 20.

2 Tarring, British Consular Jurisdiction in the East, p. 4.

' Hall, Foreign Jurisdiction of the British Crown, p. 133. "To the oriental mind a personal law is more familiar and appears more nat- 
jurisdiction over crimes committed by foreigners before the establishment of treaties with western nations. ${ }^{1}$ But, in many cases, the judicial powers of consuls in the Orient were originally accorded by a grant or charter to the merchant or commercial companies of European nations, and were eventually confirmed by treaty stipulations, as in the case of the "capitulations" of the Ottoman Empire.

The Shogun's government, in the beginning of the seventeenth century, left the Portuguese, Spanish, English and Dutch traders to their own law. This privilege, which was granted to them by letters-patent, was held at the pleasure of the Shogun, and was liable to be annulled. The Japanese, however, were more familiar with the idea of personal than of territorial law; and when, in a later age, they formed treaty relations with the West, they seem not to have insisted upon the principle of territoriality. Harris states that, when he proposed that Americans should be subject to the jurisdiction of their consuls, "to my great and agreeable surprise this was agreed to without demur." 3 . Article IV of the treaty of 1857 , as concluded by Harris, runs as follows: "Americans committing offences in Japan shall be tried by the American Consul General or Consul and shall be punished according to American laws." 4

It is not certain that this provision covered civil actions;

ural than a territorial law." For an historical account of consular jurisdiction, see Martens, Das Consularwesen im Orient, pp. 44 et seq.

1 See the report of Mr. Cushing, Commissioner of the United States, to negotiate a treaty with China, U.S. House Ex. Doc., 28th Congress, ad Session, no. 69, pp. I-I5.

2 See Van Dyck, Capitulations of the Ottoman Empire since the Year II5O.

3 Griffis, The Diary of Tozensend Harris, p. I24.

4 Treaties and Conventions of the United States since 1776, edition of 1873, p. 5I5. 
but, by the treaty of 1858 , the grant of consular jurisdiction was enlarged, and it was still further increased by the British treaty of the same year. The treaty with AustriaHungary, in 1869 , still further expanded the jurisdiction, as follows :

All questions in regard to right, whether of property or of person, arising between Austro-Hungarian citizens residing in Japan shall be subject to the jurisdictions of the Imperial and Royal authorities. In like manner the Japanese shall not interfere in any question which may arise between Austro-Hungarian citizens and the subjects of any other Treaty Power.

Austro-Hungarian citizens, who may commit any crime against Japanese subjects or the subjects of any other nation, shall be brought before the Imperial and Royal Consular Officer, and punished according to the laws of their country.

Any case involving a penalty or confiscation by reason of any breach of this Treaty, the Trade Regulations, or the Tariff annexed thereto shall be brought before the Imperial and Royal Consular authorities for decision. ${ }^{1}$

The other treaty powers of the West were accorded the same concessions by virtue of the most-favored-nation clause.

Analyzing the treaty provisions, we find that the jurisdiction belonging exclusively to consuls embraced, in civil matters: (I) cases in which a citizen of a treaty power was liable to a Japanese subject; (2) actions between citizens of the same treaty power; (3) actions between citizens of different treaty powers; and, in criminal matters: ( $\mathrm{I}$ ) offences committed by citizens of treaty powers against Japanese subjects ; (2) crimes committed by subjects of treaty powers against foreigners (including citizens of non-treaty powers, such as Turks, Persians, Chilians, Colombians, Venezuelans or Argentines); and (3) offences committed by citizens of treaty powers in violation of treaty provisions

${ }_{1}$ See articles 5, 6 and 7. State Papers, vol. 59, pp. 53I-532. 
and trade regulations. ${ }^{1}$ The residuary jurisdiction, which might be claimed for the Japanese courts, embraced, in civil matters: (I) cases in which a Japanese was liable to a citizen of a treaty power; (2) cases in which a foreigner was liable to the Japanese sovereign or government; (3) cases in which a citizen of a non-treaty power was liable to a citizen of a treaty power; and, in criminal matters: (I) offences committed by a Japanese against a foreigner; (2) crimes committed by a foreigner against the imperial House or government of Japan; (3) violations by a citizen of a treaty power of a law or ordinance on a subject not covered by the treaty (such as games, lottery and sanitary laws, and regulations of the coasting trade). This residuary jurisdiction, however, was not successfully claimed for the Japanese courts, because the treaties were not strictly construed as legal documents. ${ }^{2}$ Taking historical conditions into consideration, it was natural that the western nations should wish to make their jurisdiction as extensive as possible, so long as Japan remained in the old civilization. But it was ludicrous that, when the Japanese administration of justice had become efficient and trustworthy, the treaty powers should claim extra-territorial jurisdiction to the extent of extraditing fugitive criminals, and supervising harbor and pilotage regulations, the opium trade and quarantine, all of which undoubtedly belonged to Japan. ${ }^{3}$ Under this system, the actual condition of consular jurisdiction

${ }^{1}$ Nakamura, Shin-Joyaku-ron (Essay on the New Treaties), p. 349.

${ }^{2}$ Pigott, Consular Jurisdiction and Residence in Oriental Countries, p. 85 .

${ }^{3}$ While the treaty powers, except the United States, claimed that these regulations came within their extra-territorial jurisdiction, Japan maintained that they were within her discretion and incorporated them into her national legislation. For. Rel. of United States, vols. for 1874, 1875 and 1878. As to extradition, see Moore, Extradition, vol. i, sections 93,487 and 488 . 
could not be defined, without consulting the legislative acts of the treaty powers, the diplomatic correspondence, the decisions and procedure of the consular courts, and the works of publicists. ${ }^{1}$

The Japanese were originally ignorant of the method of raising state revenue by means of a tariff. Shogun Iyeyasu gave free entry to the imports of European traders in the seventeenth century. In the feudal régime, the land tax was the government's main source of revenue. It was Harris who first taught the Japanese to lay customs duties. In the regulations attached to the commercial treaty of I858, articles of importation were arranged in schedules. ${ }^{2}$ "Class I" included articles free of duty, such as silver and gold, wearing apparel in actual use, household furniture and printed books for private use. "Class II" embraced articles used in the building, rigging or fitting out of ships, salted provisions, bread-stuffs, living animals, coal, rice, paddy, steam machinery, etc., paying a duty of five per cent.; and "Class III," all intoxicating liquors, which were subject to a duty of thirty-five per cent. "Class IV" imposed a duty of twenty per cent on articles not mentioned in any preceding class. All Japanese products, except gold and silver, coins and copper in bars, were dutiable at five per

${ }^{1}$ Hall maintains that even the "territorial sovereign, if he chooses to bring an action, [may] submit himself" to an English court in his territory. See his Foreign Jurisdiction, p. 193. In I892 the Japanese cruiser "Chitose" collided with the English merchantman "Revana" in the territorial waters of Japan and the former was sunk. The Japanese government brought an action in the British consular court at Yokohama. For special treatment of consular jurisdiction in Japan, see Sheppard, Extraterritoriality; Senga, Gestaltung und Kritik der heutigen Konsulargerichtsbarkeit in Japan; and Scidmore's Lecture on the Consular Courts of the United States in Japan.

2 Treaties and Conventions of the United States since 1776, edition of 1873 , p. 524. Treaty with England (1858), State Papers, vol. 48, pp. 37-38. 
cent on their exportation. These tariff regulations, though arranged by convention with the treaty powers, were remarkably well conceived from the economic as well as fiscal point of view. They were not protective, but permitted virtual free trade, which is desirable for a nation "politically independent, but economically in a very low stage;" ${ }^{1}$ they were not so indulgent as to fail to produce an adequate revenue. Subsequently, however, when the Shogun's gavernment was embarrassed by the anti-foreign movement, the treaty powers took advantage of the opportunity to conclude on June 25,1866 , a treaty by which the tariff was revised and reduced. ${ }^{2}$ All food-stuffs, including grain and meat, were admitted free of duty, while tobacco, sugar and all manufactures - woolen, cotton and metallic - were charged a fixed duty of five per cent; and even articles of luxury-jewels, diamonds and gold, perfumes and champagnes-could not be taxed more than five per cent ad valorem. Under such a system, Japan largely lost the fiscal value of her tariff.

The Revision of the Treaties and Present Treaty Relations.-Thus was Japan, though an independent state, subjected to grievous disabilities by the treaties, both in respect of revenue and of jurisdiction. It is therefore not strange that, after the imperial government had restored order, the revision of the treaties, so as to recover judicial and fiscal autonomy, became a burning question among officials as well as among the people. The government,

1 Roscher, Political Economy, vol. ii, p. 434. Entire freedom of trade with the outside world "causes the influence of the incentives, wants and means of satisfaction of a higher civilization to be felt soonest in the country."

2 A convention with the United States, England, France and Holland. State Papers, vol. 58, p. 317. For the diplomatic correspondence concerning this tariff revision, see Parl. Papers, Japan, no. I (I867). 
perceiving that, so long as the country adhered to its Asiatic traditions, the treaty powers would not relinquish their jurisdictional privileges, eagerly introduced western civilization, especially in judicial institutions. The evolution of modern Japanese jurisprudence thus bears a close relation to the subject of treaty revision. Immediately after the Restoration, a separate administration of justice was instituted by the establishment of a department of justice and courts of law. ${ }^{1}$ The Kaitei-Ritsu-rei, a criminal code, was promulgated in $187 \mathrm{I}$, which, though framed upon a Chinese model, contained an infusion of European principles. Shinpai Yeto, minister of justice, as a step towards introducing western jurisprudence, invited to Japan a number of European jurists, among whom was M. Boissonade, a famous French barrister. By his eight years' labors important reforms were effected in the Japanese law. In January, 1879 , torture was abolished, and in 1880 , the regulations relating to legal practitioners and to evidence were improved and modernized. ${ }^{2}$ Criminal law and procedure were also revised, on the model of the French codes; the revision was promulgated in 1878 and came into operation in $1882 .{ }^{3}$ The third article of the criminal code prohibits the application of ex post facto laws; capital punishment by beheading was, by the twelfth article, changed to that by hanging, and was limited to munder, high treason and arson."

While judicial reform was in progress the department of foreign affairs lost no time in pressing the work of treaty revision. Iwakura, minister of foreign affairs, the first ambassador plenipotentiary ever commissioned by the imperial

1 See Dr. Okamura's paper, “The Progress of the Judicial System of Japan," Journal of the Society of Comparative Legislation (1899), p. 49.

2 For. Rel. of U. S. (1879), p. 696.

3 Okamura, loc. cit.

4 Criminal Law of Japan, arts. I16, 121, 129, 130, 292, 380, 402 and 415. 
government, was in October, 1871, sent to the United States and Europe in order to sound the governments of the treaty powers. He was courteously received, but his mission was fruitless.

The old treaties not only grieved the Japanese, but also hampered the foreigner. Foreigners could travel into the interior only with passports issued by the foreign office, and were permitted to reside only in the foreign settlements. Owing to the restrictions on travel, which had seriously inconvenienced a number of Italian merchants who were engaged in buying silk-worms' eggs, the Italian government, in 1873 , negotiated a revised treaty, by which those restrictions were to be abolished and Japan's judicial autonomy was to a certain extent to be recognized; ${ }^{1}$ but, because of the protest of the other powers, the Italian measure was not carried into effect. Count Soyejima, minister of foreign affairs, endeavored in 1874 to secure a revision of the treaties by means of a "joint conference" with the representatives of the treaty powers at Tokyo. The Korean question, the Formosan controversy, and the Saigo rebellion subsequently hindered the work; and little progress towards revision was made till Count Terajima took up the task in 1878 .

As agreement in the joint conference had depended upon the unanimous consent of all the representatives in it, Minister Terajima, upon the advice of Mr. Smith, an American counsellor of the foreign office, ${ }^{2}$ adopted the plan of negotiating separately with each treaty power, and in this way succeeded in concluding a commercial convention with the United States in July, $1878 .^{\circ}$ By this convention, the

1 The text of the draft is given in For. Rel. (1873), p. 272.

2 Ozawa, Revision of Treaties, p. I6.

3 Treaties and Conventions of the United States since 1776, edition of 1889 , pp. 627 et seq. 
United States recognized the exclusive right of Japan to regulate its tariff and coasting trade, while Japan undertook to open two additional ports and to abolish export duties; and in order to induce other treaty powers to enter into similar arrangements, it was stipulated that the compensations granted to the United States should not be extended to a third power unless it should make the same concessions. The convention, however, accomplished no practical result, since it was to become effective only on the conclusion of similar treaties by other powers, none of which followed the example of the United States.

The next foreign minister was Count Inouye, who occupied himself chiefly with treaty revision. He sought in a measure to recover Japan's judicial and fiscal autonomy, by conceding to foreigners the right to hold real property and to reside and trade throughout the empire. ${ }^{1}$ Adopting the plan of a joint conference at Tokyo, Count Inouye opener preliminary negotiations in 1882 . The foreign representatives generally were unwilling to concede the Japanese claims, but were very anxious to obtain the privileges of trading and traveling. In Japan, on the other hand, public opinion demanded the recognition of the full jurisdictional rights of the country as an independent nation, but objected to the proposed concessions to foreigners, whose business activities were viewed with apprehension. Under such circumstances, treaty revision was a difficult task. Conferences were held, but nothing definite was accomplished till I886, when, by the compromise known as "the AngloGerman project," ${ }^{2}$ the conclusion of an agreement appeared to be rendered possible during the next year, after a radical modification should have been introduced into Japanese

${ }^{1}$ Essay on Treaty Revision, Dobunkan's edition, p. 7.

${ }^{2}$ Siebold, Japan and the Comity of Nations, pp. 83-84. 
judicial procedure, by the establishment of mixed courts, as in Egypt, with prosecuting attorneys of foreign birth. When, however, the purport of the draft-treaty became known, through its publication in an English paper at Yokohama, popular opinion loudly censured Count Inouye; several outrages were committed upon him; and even Count Toni, the minister of the interior, and M. Boissonade advised the emperor that such a treaty would be inconsistent with the sovereign rights of the empire. In consequence the minister of foreign affairs, in June, 1887 , notified the foreign representatives that the treaty negotiations were adjourned. ${ }^{1}$

Count Inouye was immediately succeeded by Count Okuma. The new minister's prospects were brightened by the strong support of the political party called the KaishinTo (Progressive party), without whose aid his predecessor had failed. His policy was to consult separately with each treaty nation, as Count Terajima had done in 1878 . As a preliminary test, he concluded the treaty ${ }^{2}$ of amity and commerce with Mexico in February, 1887 , which fully recognized Japan's judicial and fiscal autonomy, and which was the first treaty ever concluded by Japan with a western state on terms of perfect equality. As it also granted to Mexicans freedom of travel, residence and trade throughout the empire, the most-favored-nation clause was inserted in the treaty in the conditional form, in order to preclude any third power from claiming the privileges granted to Mexicans without making the reciprocal concessions secured to Japan. As a matter of fact, most of the European powers claimed most-favored-nation treatment without giving Japan any compensation for it; but Count Okuma obtained the

1 For. Rel., 1887, p. 665.

${ }^{2}$ British and Foreign State Papers, vol. 79, pp. 129 et seq. 
concurrence of America, Germany and Russia, and then entered into negotiations with England. ${ }^{1}$ The principal points of the Japanese proposal for a treaty with Great Britain, which was forwarded to London in December, I888, were as follows: First, the Japanese government was to open the entire country to foreigners, and to concede to them the right to hold real as well as personal property. Secondly, five years after the ratification of the treaty, consular jurisdiction was to be abolished. Thirdly, foreign judges were to be appointed to sit as associates in the "Dai-Shin-in" (supreme court), in case the defendant was a foreigner. Lastly, although a majority of imported commodities were to be subject to the statutory tariff of Japan, certain duties on English goods were to be fixed by the convention. $^{2}$ An outline of the proposed treaty was published in the London Times of April 29, I889. It met with disapproval in Japan, especially by reason of the provisions for the appointment of the foreign judges and the ownership of real estate. The constitution of the empire had been promulgated in the preceding February, and it provided that "Japanese subjects may, according to qualifications determined in laws or ordinances, be appointed to civil or military offices equally, and may fill any other public offices." By this, foreigners were not regarded as competent to hold public office in Japan. The party in opposition to Count Okuma declared his treaty measure to be unconstitutional. As to the ownership of real estate by foreigners, conservative Japanese regarded it as having the effect of making Japanese territory a foreign domain. The popular agitation against the treaty became so intense that on

1 Annual Register (1889), pp. 397 et seq.

2 Parliamcntary Papcrs, vol. xcvi, Japan no. I (1894), pp. 2-12. Text of the draft. 
October I9, I889, a fanatic threw a bomb at Minister Okuma, and the imperial government again suspended the work of revision.

Viscount Aoki, the next foreign minister, took up the unfinished task with some modification of the draft of his predecessor. He proposed the absolute recognition of Japan's judicial autonomy, without the intervention of any foreign judges, but adhered to the concession of the right to own real estate. ${ }^{1}$ The completion of his work was prevented by the cabinet crisis of I89I, and he was succeeded by Count Enomoto, who sought to finish what he had left undone. Count Enomoto believed that, if Japan had satisfactory civil laws and civil procedure, the treaty powers would soon recognize her jurisdiction. Hence he made strenuous efforts to induce the imperial diet to approve the project of a civil code which was then under discussion. $\mathrm{He}$ declared in the Lower House, in 1892 , that the postponement of the completion of the codes would mean the postponement of treaty revision. In the previous year, the civil code, the code of civil procedure, the commercial code, and the code of the constitution of courts were promulgated; but, although the code of the constitution of courts, the code of civil procedure, and a part of the commercial code, viz., the chapters on companies, partnership, bankruptcy, bills, commercial registration and trade books-were put in force with the sanction of the Diet, the operation of the civil code and of the main parts of the commercial code was postponed until I $894 .^{2}$ When Portugal happened to withdraw her consuls from Japan, without sending new ones in their places, Count Enomoto promptly took steps to assert Japanese jurisdiction over Portuguese residents, and by an

1 Parl. Papers, Japan no. I (1894), pp. 27-29.

2 See Okamura, loc. cit. 
imperial ordinance of July I7, I892, all treaty provisions with Portugal relating to consular jurisdiction were denounced. ${ }^{1}$ Treaty revision, however, was again hindered by the cabinet crisis at the end of 1892 .

The foreign office was next occupied by Mr. Mutsu, an able and clear-headed man, who had once been minister of Japan at Washington and who had negotiated the commercial treaty with Mexico in 1887 . He conceived the idea that treaty revision might be accomplished if Japan, in the first instance, consulted the power whose interests in the country predominated over those of any other. Most of his predecessors had, in the first instance, treated with the United States, which always manifested a readiness to grant Japan's wishes, or with some of the minor countries, and the possibility of revision was in the end usually destroyed by Great Britain. Mr. Mutsu therefore decided to deal first with Great Britain. To this end he availed himself of the opportunity afforded by the presence in London of Mr. Fraser, British minister to Japan, who was then on leave. On August I8, I893, Viscount Aoki, who was then Japanese minister at Berlin, and who had known Mr. Fraser in Tokyo, was instructed to proceed to London and discuss with him "the basis of a negotiation for treaty revision." 2 With a view to such a negotiation, Mr. Mutsu, desirous of placing Japan's treaty relations on the basis of absolute equality, had drawn up a draft on the model of the AngloItalian treaty of $\mathrm{I} 88 \mathrm{I}$, which was formed on that basis. This draft was sent to Viscount Aoki, and, after an informal discussion between him and Mr. Fraser, was submitted to the British foreign office on December $27,1893 .^{3}$ Negotiations between Count Aoki and Lord Kimberley, who was

1 Horei-Zensho (1892), vol. vi, p. 147. Imperial ordinance no. 65.

2 Parl. Papers, Japan no. I (1894), p. 75. 3 Ibid., pp. 76-83. 
then secretary for foreign affairs, soon ensued. While they were pending, the British chargé d'affaires at Tokyo sent to London translations of speeches made by Count Ito, prime minister, and by Mr. Mutsu, in the Upper House, in which they seem to have intimated that Japan would repudiate the existing treaties, in case the powers should disregard her wishes for revision. This report caused illfeeling in London, and Lord Kimberley declared that such language would "retard rather than advance the revision" which Japan desired. ${ }^{1}$ The incident was in fact due to a sensational translation, the meaning of the original being that Japan could no longer bear up under the weight of the old treaties. On Mr. Fraser's return to Tokyo, all misunderstanding was removed. While negotiations with Great Britain were in progress, Mr. Mutsu on April Io, I894, seized an opportunity to obtain from the Hawaiian government by exchange of notes the recognition of Japanese jurisdiction over citizens of Hawaii in the empire. ${ }^{2}$

Happily for Japan, the question of treaty revision, which was so long under discussion, finally came to a definite solution with Great Britain. On July 16, 1894, a treaty of commerce and navigation was signed without any significant departure from the original draft. ${ }^{3}$ Japan, by her civilized conduct during the war with China, had gained much reputation and credit, and other powers were not slow to imitate the example of Great Britain. New treaties were signed with other powers as follows: the United States, November 22, and Italy, December I, I894; Russia, June 8, Denmark, October I9, and Peru, March 22, I895; Ger-

1 Parl. Papers, Japan no. I (1894), pp. 98 and 99.

${ }^{2}$ British and Foreign State Papers, vol. 86, pp. II85 et seq. Also Imperial Ordinance no. 4I, April II, I894, Horei-Zensho (1894), vol. iv, p. III.

3 Parl. Papers, Japan no. I (1894), pp. 129 et seq. 
many, April 4, Sweden and Norway, May 2, Belgium, June 22, France, August 4, the Netherlands, September 8 and Switzerland, November 16, 1896; Spain, January 2, Portugal, January 26 and Austria-Hungary, December 5, 1897; Siam, February 25, I898. The ratifications of all these treaties were completed in 1898 . The treaty with Mexico of 1887 required no revision; but the Anglo-Japanese treaty of 1894 was adopted as the basis of all these revised treaties. $^{1}$ Beside these revised treaties, Japan concluded treaties for the first time with Brazil, November 5, 1895; Argentine Republic, February 3, 1898; and Greece, May 20 and June I, 1899. On January I7, I900, Japan and the Congo Free State entered into a declaration mutually to extend most-favored-nation treatment in regard to commerce and navigation. ${ }^{2}$

By the revised treaties, Japan not only recovered her judicial autonomy, but also secured equal treatment for her people in the western countries. The old treaties were onesided arrangements, designed to secure certain rights and privileges to aliens in Japan. They did not provide for the reciprocal protection of Japanese abroad, and in reality few Japanese ever appeared in western lands in those days. Subsequently, however, the number of Japanese going abroad for travel, trade and education steadily grew; and the new treaties were therefore necessarily founded in this respect on the principle of reciprocity. Their main provisions may be summarized as follows: The subjects of each contracting party are to enjoy in the dominions of the other freedom of travel, residence, commerce, navigation

1 The texts of all these revised treaties of Japan are found in Treaties and Conventions between Japan and Other Powers (edition of 1898), and in the British and Foreign State Papers.

2 These treaties and declarations are found ibid., vol. 92. 
and religion, and of access to the courts of justice, together with national or most-favored-nation treatment in respect to the possession of goods, succession to personalty, disposal of property and taxation. The houses of aliens in each country are protected from search and domiciliary visits except according to law. Foreigners are exempt from military services and compulsory contributions. Mostfavored-nation treatment is preserved in commerce and navigation; and particularly in respect to imports and exports, tonnage and other shipping duties, consular officers, and the coasting trade, although they are mostly subject to national law. As regards warehouses, bounties, drawbacks, shipping facilities, patents and trade marks, foreigners are to enjoy the same rights and privileges as natives. The revised treaties all came into operation in July and August, I899. From that moment the system of foreign settlements (which had hitherto enjoyed extra-territoriality) was abolished and the settlements were merged into the general municipal system. Consular jurisdiction also ceased.

In the matter of trade, Japan made liberal concessions to England, France and Germany upon their principal imports. By the conventional tariffs appended to the treaties with those countries, their imports were taxed only from five to fifteen per cent $a d$ valorem, while the statutory tariff of the empire fixed, in all other cases, rates running from five to forty-five per cent; ${ }^{1}$ nor was the large reduction made on imports from those countries compensated by any concession in favor of imports from Japan. The conventional tariff with Austro-Hungary, however, was more

1 The conventional tariffs are found in Appendix A, Treaties and Conventions between Japan and Other Powers (edition of 1899). The new statutory tariff is in ibid., Appendix B; see also Horei-Zensho, 1897, vol. iii, pp. 13 et seq.; and Consular Reports of U. S., no. 204 (Sept., 1897), p. 9 I. 
nearly reciprocal, that government granting to five classes of Japanese commodities reductions in rates in return for reciprocal reductions on five classes of Austro-Hungarian goods in Japan. ${ }^{1}$ The treaty powers, other than those mentioned, enjoy the benefit of the conventional tariffs by virtue of the most-favored-nation clause. By the treaty with Portugal, the most-favored-nation treatment in that country is restricted to thirty-three Japanese articles, while twentytwo Portuguese articles enjoy like treatment in Japan. ${ }^{2}$

The articles subject to the conventional tariff in Japan number nearly sixty, and, as they include the principal imports from western countries, embrace the most significant part of the foreign trade of the empire. The conventional tariff thus holds an important relation to national finance and economy. The increasing burdens of a progressive nation can be best borne by means of the revenue from customs receipts, and, owing to the conventional reductions, the tariff of Japan does not produce an adequate income. The customs receipts of Japan in I9O hardly amounted to 6 per cent of the total revenues; while those of France yielded 26 per cent; of Germany, 30 per cent; of Great Britain, 23 per cent; of Russia, I I per cent; and, of the United States, 40 per cent. ${ }^{3}$ From an economic point of view, the promising industries of Japan-as yet infant industries-such as woolen, cotton, sugar and glass manufactures, cannot be satisfactorily developed, because similar manufactured goods from other countries are admitted under the low rates of the conventional tariff. In these days of protective tariffs and of heavy national burdens, Japan

${ }^{1}$ British and Foreign State Papers, vol. 89, pp. $99 \mathrm{I}$ et seq. See "Additional Convention" between Japan and Austro-Hungary.

2 British and Foreign State Papers, vol. 89, pp. 970 and 976 et seq.

3 These percentages are calculated from the statistics in The Statesman's Year-Book, 1902. 
must stand at a great disadvantage till I9I I, when the present treaties will expire. The sensational press of Japan criticised and denounced the "poor work" of the treaty revisers, but the representatives of Japan did the best they could. Great Britain, Germany and France, with their large commercial interests, demanded commercial concessions as the price of recognizing Japan's judicial autonomy.

By the revised treaties, concluded with western nations on an equal footing, and with the absolute abolition of the foreign consular jurisdiction, Japan has been admitted into the "family of nations" as a competent member and a subject of international law. According to the orthodox "law of nations," the "family of nations" was regarded as the monopoly of Christendom; but, since the Reformation, which destroyed the religious unity of Europe, the religious test of international right has gradually fallen into disrepute among jurists. At the present day, the accepted test is the possession of the modern civilization developed in the states of western Europe and their derivatives in America. Turkey, though her civilization is not European, was formally admitted to participate in "the public law and concert of Europe," 1 chiefly for political reasons, by the Treaty of Paris of 1856 ; but her judicial power over aliens is still limited. Although Japan is different, racially and religiously, from the Occident, her healthy assimilation of western civilization made the occidental states recognize her as eligible to the "family of nations." The antipathy at first felt by the Japanese towards foreigners disappeared, and was quickly replaced by the eager adoption and adaptation, so far as seemed to be practicable and desirable, of European science, ethics, arts, education, military methods,

1 Article vii of the Treaty of Paris of March 30, 1856. Hertslet, The Map of Europe, vol. ii, p. 1250. 
politics, judicial administration and other economic and social institutions. Freedom of religious faith is secured by constitutional provision. ${ }^{1}$ The criminal and civil codes, and the codes of procedure, which, after long elaboration, were completed in 1898 and, with the final revision of the commercial code, came into force in 1899, have freely incorporated the judicial principles which prevail in the Occident. $^{2}$ So liberal is the civil code to foreigners that they can enjoy all the private rights of natives "except as forbidden by law, regulation, or treaty," 3 . while, under the criminal procedure, foreign prisoners are specially provided with Euorpean meals and quartered in European buildings, because their standard of living is different from that of the Japanese. ${ }^{4}$ In a word, under the existing administration of

1 Art. xxviii of the Japanese Constitutional Law.

2 The code of civil and commercial law, which was originally framed by Boissonade on the model of the French code, was afterward replaced by a code framed on the German model by a commission of native jurists. The reasons for this entire revision of the civil code are said to be as follows: The first civil code "rendered frequent repetition of the same rules necessary in different parts of the code," and made the whole work voluminous, so that it contained 1,762 articles. In order to avoid this unnecessary repetition and make "the body of the law succinct," the new code followed the forms of the Saxon civil code and the draft of the imperial German civil code, and is comprised in I,I 46 articles. See Hozumi, The New Civil Code, a Study in Comparative Jurisdiction, p. 23.

${ }^{3}$ Article ii of the Japanese Civil Law. Ume, Minpoyogi (Interpretation of the Civil Law), vol. i, pp. 8 et seq. See also Dr. Masujima's address delivered before the New York State Bar Association in January, 1903. "The cases in which foreigners are restricted in enjoyment of private rights are, the ownership of land or Japanese ships, the rights to work mines, to own shares in the Bank of Japan or the Yokohama Specie Bank, to be member or broker of exchanges, to engage in emigration business, or to receive bounties for navigation or shipbuilding."

${ }_{4}$ See Report of International Prison Congress, Belgium, 1900, sec. an Japan. 
justice, aliens are as secure in person and in property in Japan as in any country in the world.

In her international relations, Japan not only faithfully fulfils her treaty obligations, but also abides by the rules of international law. When the Franco-Prussian war broke out in 1870 , she declared her strict neutrality. ${ }^{1}$ When a Peruvian ship, the "Maria Luz," entered the harbor of Yokohama in 1872 , Japan righteously exercised her territorial jurisdiction against the slave traffic. ${ }^{2}$ Japan has also been sedulously observant of the dictates of courtesy and comity. In 1885 her troops protected the American legation at Seoul against conflagration. ${ }^{3}$ When, in 1888 , the Turkish man-of-war "Ertugrul," was wrecked on the Japanese coast, the survivors, although Turkey was not a treaty power, were taken to Constantinople by the "Hiyei" and "Kongo," Japanese men-of-war, which were said to be the first war vessels that had passed the Dardanelles since 1856. The Grand Duke Alexis of Russia, the Duke of Edinburgh, the crown prince of Germany (the present Kaiser), General Grant (ex-president of the United States), the king of Hawaii, the crown prince of Russia (the present Czar), the Turkish Prince Osman Pasha, and other distinguished personages have been received upon their visits to Japan by the present emperor and his people, with marked hospitality and politeness. The conduct of Japan during the Chino-Japanese war is admitted to have furnished a consummate illustration of adherence to international law. ${ }^{4}$

1 For. Rel. (1870), p. I88.

2 The action of the Japanese authorities raised a dispute with Peru, which was decided by the Czar of Russia, Alexander II, in favor of Japan. See Moore, International Arbitrations, vol. v, pp. 5035-36.

3 For. Rel. (1885), p. 562.

${ }^{4}$ As to the naval side, see Takahaski, International Law During the Chino-Japanese War. As to the military side, see Ariga, La Guerre Sino-Japonaise. 
The "Kowshing" case, which created some ill-feeling among neutral powers, was subsequently justified by eminent authorities on international law. ${ }^{1}$ Since I884, Japan has become a signatory or adherent of the " universal conventions" which are regarded as facilitating the social, political and commercial life of the international society, such as agreements concerning the sick and wounded in war, weights and measures, posts, telegraphs, trade-marks and patents, and copyrights. ${ }^{2}$

It is proper to add that, while Japan has, by reason of her healthy assimilation of western civilization, been admitted into the "family of nations" as an equal member, without regard to religious and racial differences, she has retained her consular jurisdiction in China, Korea and Siam.

1 Letters of Professors Westlake and Holland, in the London Times, August 3 and 7, 1894, justifying the sinking of the English ship "Kowshing," while transporting a hostile Chinese force to Korea, by the Japanese man-of-war "Naniwa."

2 Japan, after becoming a party to the international convention for the protection of submarine cables, in 1884 , adhered to the Geneva Convention (Red Cross), the Universal Postal Union, the Convention for the Establishment of an International Bureau of Weights and Measures, and the Declaration of Paris in relation to Maritime Law. See Treaties and Conventions between Japan and Other Powers, ed. 1889, vol. ii, "Universal Conventions," pp. 92 ct seq. Japan also pledged herself in her revised treaties to be bound by the Berne Convention (copyright) and the Industrial Property Convention. 


\section{CHAPTER VII}

International Relations of Japan with Asiatic NAtions, I 868-1898

The First Treaty with China.-Although the Asiatic nations entered, in the middle of the nineteenth century, into diplomatic and commercial relations with western nations by treaty stipulations, they had no resident embassies nor any treaties regulating trade among themselves, until China and Japan concluded their first treaty in 1871. Nevertheless, intercourse had previously existed.

After Hideyoshi's invasion of Korea and China, the Ming dynasty in the latter country declined to make peace with Japan, although the Shogun's government often tried to bring it about. Subsequently, however, the Ming dynasty, when it was about to be overthrown by the Manchus, several times solicited the military assistance of Japan through the governor of Nagasaki and the king of Loochoo; ${ }^{1}$ but the conservative government of the Tokugawa refused to become entangled in foreign affairs. The Manchu dynasty at length came in 1659 to rule the whole of China, but diplomatic intercourse with Japan was not restored. Nevertheless, commercial intercourse bewteen the two nations remained undisturbed. During Japan's War of Restoration, of I868, China did not, like the western nations, maintain neutrality. Chinese traders supplied contraband to the revolted Tokugawa, while Chinese subjects in Japanese ports were often guilty of smuggling opium and kidnapping

${ }^{1}$ Gaiko-Shiko, pp. 282-283. 
Japanese girls. These outrages showed the importance of establishing treaty relations with China. Besides, when the Japanese government, soon after the Restoration, sought to enter into a treaty with Korea, it found itself thwarted by the peculiar relation of Korea to China. It therefore determined first to conclude a treaty of amity and commerce with the latter country.

Such a treaty was concluded at Peking in July, I87 I, on absolutely equal terms, "without depreciation on either side." ${ }^{2}$ It was based upon the most thorough amity. In case either contracting party was aggrieved by a third power, the other was to render "assistance" or exercise "good offices." This stipulation was described in the occidental press as an "alliance" of the Asiatic nations against the western. Permanent embassies were reciprocally established, and it was expressly provided that the ambassadors should bear their own expenses, although it had been the custom in Asia to pay all the expenses of foreign embassies on the assumption that an ambassador was the guest of the nation. But, while the treaty was made after the western fashion, it still exhibited Asiatic peculiarities. It retained the oriental element of personal law, the consuls of the contracting parties being clothed with jurisdiction over their fellow citizens; and both countries agreed to deliver up fugitive criminals to the consuls. The treaty further provided for the confiscation of contraband. It contained no most-favored-nation clause. The contracting parties were unwilling to extend to each other by treaty the large favors and privileges which they had granted to western nations. On the contrary, they agreed that their imports and exports should be re-

1 The Japanese text is in Horei-Zensho, 1873, pp. 540 et seq.; the English text in British and Foreign State Papers, vol. 62, p. 321, and For. Rel., I872, p. 485 . 
gulated by their respective tariff laws. They did not, however, enact new tariffs, but adopted the trade regulations embodied in their treaties with European nations. It is interesting to note that the treaty specifically prohibited the export of rice and salt, ${ }^{1}$ since it was apprehended that, as those articles formed an essential part of the diet of the people, their exportation would ruin both nations. Such were the economic ideas of oriental statesmen at that time.

The Formosin Question.-In September, I87 I, sixty-six inhabitants of the Loochoo Islands, which, since their invasion in 1609 by Shimazu, lord of Satsuma, had been claimed by Japan, ${ }^{2}$ were wrecked on the southern coast of Formosa, and were murdered by the "Boutans," one of the savage tribes. Four years before, a similar cruelty had been inflicted upon the captain and his wife and the officers and crew of the American ship, "Rover." As the Chinese government neglected to redress this outrage, General Le Gendre, then American consul at Amoy, himself proceeded with an expedition to Formosa and obtained from Tooketok, a native chief, a pledge of good behavior. ${ }^{3}$ The agreement, however, proved to be of no avail, and further murders of Loochooans were soon committed. The Japanese government then seriously took up the matter, the celebrated diplomat, Mr. Soyejima, being minister of foreign affairs; and General Le Gendre, who happened to pass through Japan on his way to America, was, by reason of his experience in dealing with Formosan savages, engaged as special adviser. ${ }^{4}$ The imperial government eventually decided, before sending out an armed expedition, to despatch

1 Trade Regulations between Japan and China, arts. xxi and.xxv.

2 Infra, p. 160.

${ }^{3}$ Le Gendre to Mr. Burlingame, American minister at Peking, Dip. Cor. (1868), part I, p. 508.

4 Black, Young Japan, vol. ii, p. 403. 
an envoy to ascertain the views of the Chinese government as to its responsibilities in the premises. There were pending at this time the questions of opening up Korea, of the ratification of the Chino-Japanese treaty of $187 \mathrm{I}$, and of an audience of the foreign representatives with the Celestial emperor. Mr. Soyejima was therefore commissioned, in I873, as the ambassador extraordinary and plenipotentiary to China, and was accompanied by General Le Gendre. He also bore an imperial letter to the Chinese emperor, congratulating him on his recent marriage. The ratifications of the treaty were exchanged at Tientsin on April 3; and Mr. Soyejima then proceeded to Peking, where he persistently demanded an audience on the ground that the imperial letter addressed to the Chinese emperor must be delivered in person, as had been done by Harris in Japan. The Chinese government finally yielded, and the Celestial emperor gave his first audience to the Japanese ambassador on June 29, I873. A similar concession was immediately made to the other foreign representatives. ${ }^{1}$ As to the Formosan question, the Chinese government took the ground that the Loochooans were "Chinese subjects," and that the outrages upon them therefore did not concern any other government. The Japanese ambassador, on the other hand, affirmed that the Loochooan sovereignty had belonged to Japan since I609, and demanded specific redress for the acts of the Formosan savages. In order to evade responsibility, the Chinese commissioners incautiously declared that their government had nothing to do with the inhabitants of southern Formosa, who were out of its control and jurisdiction. $^{2}$ As to the Korean question, the Chinese commissioners, after long discussion, declared that China would,

1 For an account of the audience question, see For. Rel., 1873, pp. 195 et seq.

${ }^{2}$ Black, Young Japan, vol. ii, p. 404. See also For. Rel., 1873, p. 188. 
while maintaining the old tributary relation of Korea, recognize her right to make peace and war with other states. ${ }^{1}$ The Japanese ambassador left Peking in July, announcing that Japan, being an independent state, would take the necessary steps to chastise the savages of Formosa who were " out of the jurisdiction" of the Chinese government, and would also independently open Korea.

On receiving the report of $\mathrm{Mr}$. Soyejima, a majority of the cabinet recommended that an expedition be undertaken first to Korea. Shortly afterwards Count Iwakura, envoy to America and Europe, returned to Japan and condemned the warlike policy, especially attacking the proposed Korean expedition. The cabinet was then reorganized by the Heiwato, or peace party, but it was unable to stem the current of popular feeling. The late minister of war, General Saigo, and the ex-minister of justice, Yeto, retired to their own provinces and plotted the overthrow of the new cabinet; Prime Minister Iwakura barely escaped assassination at Kuichigai. The imperial government finally determined to send an expedition to Formosa, in order to appease the warlike spirit and maintain peace at home. The expedition was officially announced on April I7, I874, and Major Saigo, younger brother of General Saigo, was appointed to command it. $^{2}$ American transports and officers were to take part. Ex-Lieutenant-Commander Cassell, United States navy, was offered the rank of lieutenant-commander in the Japanese navy, Lieutenant Wasson was engaged as a military engineer, and General Le Gendre was attached to the "Banchi-Jimu-Kioku" (staff of the expedition against the savages). These Americans, however, were discharged before the arrival of the expedition at Formosa,

${ }^{1}$ Ogawa, Meiji-Gaiko-Yoroku (Digest of Diplomacy of the Meiji Era), p. 86.

2 For. Rel., 1874, p. 680. 
because of the protest of Mr. Bingham, American minister at Tokyo, who maintained the strict neutrality of his country. ${ }^{1}$ By May 22, 1874, all the "Boutans" had surrendered and the southern part of Formosa was occupied by the Japanese forces.

Meanwhile, Mr. Yanagiwara had been sent as Japanese ambassador to China, in order to prevent any misunderstanding as to the objects of the expedition. A few days after his departure, the Chinese government lodged a protest with the Japanese foreign office, alleging that China had been assured by Mr. Soyejima that Japan would limit her action to an official remonstrance to the guilty tribe, and insisting on the immediate evacuation of Formosa by the Japanese forces. ${ }^{2} \quad \mathrm{Mr}$. Yanagiwara held several conferences, but, as he obtained no practical result, Okubo Toshimitsu, a leading member of the Japanese cabinet, was on October I sent to Peking as plenipotentiary, armed with full power to do whatever was necessary to the success of his mission. In his negotiations at Peking, he maintained the righteousness of the expedition and defended the occupation of southern Formosa, pointing out the right of civilized states under international law to occupy savage lands " out of the jurisdiction" of any independent power. ${ }^{3}$ The commissioners of the Tsung-li Yamen replied that the Chinese government had little to do with the "law of nations," declaring that such law regulated the affairs of Europe but not those of the Orient, and firmly asserted China's sovereignty over Formosa, on the strength of numerous proofs from historical records and official docu-

${ }^{1}$ For. Rel., 1874, pp. 677 and 681.

2 Ogawa, Meiji-Gaiko-Yoroku, p. 42.

${ }^{3}$ Gaiko-jiho (Rcvue Diplomatique), no. 50, p. 20. Count Okubo referred to Vattel, vol. i, chap. 18, par. 208; G. F. de Martens, vol. ii, chap. i, par. 37-38; Heffter, par. 70, and Bluntschli, par. 277. 
ments. ${ }^{1}$ The discussion continued until the Chinese government had recognized the justice of Japan's action and had offered to pay an indemnity on the withdrawal of the Japanese forces. The Japanese plenipotentiary then demanded 3,000,000 taels as the actual cost of the expedition, and in addition an indemnity for the families of the slain Loochooans and a treaty pledge for the future redress of savage outrages. Upon the refusal of the Chinese to agree to these demands, the Japanese plenipotentiary on October 25 sent to the Tsung-li-Yamên an ultimatum, ${ }^{2}$ in which he declared "that, as the present case cannot be decided by argument, each country must go its own way and exercise its own right of sovereignty." While the Japanese representatives were preparing for their departure, Mr. Wade, the British minister at Peking, offered his mediation, ${ }^{3}$ with the result that a convention was signed at Peking on October 3I, I874, by which China agreed to pay to Japan I0o,ooo taels for the families of the men killed in $187 \mathrm{I}$, and 400,000 taels on the complete withdrawal of her forces from Formosa. Although Japan did not recover a fifth of her expenses, yet, by her expedition, she made herself and other commercial nations secure from further attack by savages in oriental waters.

The Loochoo Complication.-After the Formosan affair, another complication arose between Japan and China, concerning the Loochoo Islands. The political status of the islands had, like that of Korea, been very obscure. These petty kingdoms in Asia, though they maintained de facto independence, had feebly preserved their existence from absorption by neighboring empires through their tributary re-

${ }^{1}$ Gaiko-jiho (Revue Diplomatique), no. 5I, pp. 80 and 86.

2 Black, Young Japan, vol. ii, p. 442.

${ }^{3}$ Moore, International Arbitrations, vol. v, p. 4857 ; British and Foreign State Papers, vol. 66, p. 422, and For. Rel., 1875, p. 222. 
lation to Japan and China. It is said that, in the middle of the twelfth century, the Minamoto general, Tanetomo, exiled to the island of Idzu, made his way thence to Loochoo and, having quelled a civil war then raging in the islands, placed his son Shunten on the throne. Loochoo began to pay tribute to China as early as the first year of Hung-wa of the Ming dynasty ( 1372 ). She entered into a similar relation with Japan during the period of the Ashikago reign ( $145 \mathrm{I}$ ). When the Loochoo government, in the beginning of the seventeenth century, neglected its tributary duties to Japan, Shimazu, the lord of Satsuma, in the fourteenth year of the Keicho era (I609 A. D.), sent an expedition to the island, and brought its king to Satsuma. ${ }^{1}$ Since this event, Japan has claimed sovereignty over Loochoo. When Commodore Perry came to Japan, he asked the Japanese commissioner to open Napa-Keang, the capital of Loochoo, for American ships. The reply was that "Loochoo is a very distant place, and a definite answer cannot be given." ${ }^{2}$ From this answer the Commodore, inferring that he could freely enter into treaty negotiations with Loochoo, as if it were an independent kingdom, concluded a treaty of amity on his way home, on July I I, I $854 .^{3}$ This example was followed by France and by the Netherlands.

After the Restoration in I868, the imperial government, being busily occupied with the Korean question did not concern itself with Loochoo until June, 1872, when the Loochoo government reported to Governor Oyama, of Satsuma, the massacre of the shipwrecked Loochooans at Formosa. The government, availing itself of this opportunity, ordered

1 See Satow's note on Loochoo, Transactions of the Asiatic Socicty of Japan, vol. i, pp. I-2.

2 Senate Doc., 2d Session, 33d Cong., no. 34, pp. I30 and I39.

I Ibid., p. 174. 
Sho-tai, king of Loochoo, to proceed to Tokyo in order to offer congratulations to the Mikado upon the Restoration. ${ }^{1}$ The king excused himself on the ground of illness, but sent the young prince, who arrived at Tokyo on September I3. The prince being respected more than the ordinary daimio, or nobility, he was received, with his suite, by the department of foreign affairs. In September, by successive imperial ordinances, Sho-tai, king of Loochoo, was privileged to join the $K a z o k u$, or noble class, with gifts of a residence in Tokyo and 30,000 yen; the originals of his treaties with the United States, France and the Netherlands he was ordered to hand over to Japan; and all diplomatic affairs were directed to be in the future administered by the Japanese foreign office. ${ }^{2}$ When Mr. De Long, the American minister at Tokyo, inquired as to the effect of these measures on the treaty relations of Loochoo with the United States, the reply was made that the provisions of the treaty would be observed by Japan. ${ }^{3}$ In September, I873, Japan, at the request of the Italian government, granted mostfavored-nation treatment to its subjects in Loochoo." By the settlement of the Formosan trouble in 1874, China tacitly recognized the sovereign rights of Japan over the Loochoo Islands.

Although these facts confirmed the political dependence of the Loochoo Islands on Japan, de facto and de jure, Japan had not interfered with their tributary relation to China. After the Formosan affair, however, the Japanese government decided to annul this relation. By ordinances in 1875

1 Ogawa, Diplomacy of the Meiji Era, p. 64.

${ }^{2}$ Horei-Zensho (1872), pp. 200 and 505.

3 Ogawa, Diplomacy of the Meiji Era, p. 66; For. Rel., I873, part I, p. 555 .

4 British and Forcign State Papers, vol. 65, p. 740. 
and 1876 , a governor was installed, protected by military guards; the king was required to renounce his Chinese investiture as well as the payment of tribute to China, and to substitute the Japanese calendar for the Chinese; and the Japanese courts were ordered to administer justice in the islands. The pro-Chinese officials were unwilling to renounce their Chinese allegiance, and envoys were sent to China and Japan to solicit the privilege of bearing a joint allegiance. The appeal was rejected by the Japanese government, and the young prince, the Loochoo envoy, applied in vain, in 1876 , to the ministers of the United States, Netherlands, France and China at Tokyo, to exercise their good offices. ${ }^{1}$ In 1878 the Chinese government, which did not desire to act alone, solicited the good offices of the United States. ${ }^{2}$ In the following year, General Grant, while on his journey around the world, offered his mediation, but it brought no practical result. ${ }^{3}$ Japan declined to make even the slightest concession. By a proclamation in March, 1879, she incorporated the islands into the general administration, ${ }^{4}$ and, by a proclamation in 1880 , she assumed liability for the public debt of the islands contracted since $1844 .{ }^{\circ}$ The efforts of General Grant, however, brought Japan and China into negotiation, and in October, I880, a treaty was drawn up, but the Chinese representatives afterwards refused to sign it. ${ }^{\circ}$ Eventually, China seems to have acquiesced in the Japanese claim. ${ }^{7}$

1 Ogawa, Diplomacy of the Meiji Era, p. 69.

2 For. Rel. of U. S., 1879, p. 607.

${ }^{3}$ Moore, International Arbitrations, vol. v, p. 5047.

- For. Rel., 1879, p. 637. See also Horei-Zensho, 1879, no. 40.

- For. Rel., 1880, p. 686.

- For. Rel., I881, p. 230.

7 Moore, International Arbitrations, vol. v, p. 5048. 
Japan's Policy to open Korea to the World.-Korea, though she had long held a vassal relation to Japan and China, gradually neglected her duty to Japan after the invasion of Taidsoong, of the Manchu dynasty in 1634 , and her tribute to Japan finally ceased after the eighth year of the Bunka era (I8II). ${ }^{1}$ Yet, the Lord-Governor So, of Tsushima, maintained undisturbed the usage of Saikensen -the custom of sending a certain number of Japanese junks to Fusan, a southern port of Korea, for the barter of the national products of the two nations. After the revolution of I868, Lord So was sent to Korea, as an envoy, formally to announce the resumption by the Mikado of the imperial sovereignty and to invite the Koreans to re-establish the old relations. ${ }^{2}$ As the So mission obtained no satisfaction, the Japanese government in the following year sent three commissioners to investigate the internal condition and foreign relations of Korea. It was represented that the secret designs of Russia, coupled with Chinese control in the peninsula, would endanger the existence of the Hermit Nation, and that it was of vital importance to Japan to take measures for its preservation. ${ }^{3}$ The envoy Hanabusa was sent, with two men-of-war, in 1872 , to open the peninsula, but he returned disappointed. Previously attempts of France and the United States, in I866 and I87I, had likewise failed." The obstinacy of the Koreans so incensed General Saigo that he insisted upon an immediate expedition for their chastisement, but a majority of the cabinet voted to try " the subtle movement of diplomatic finesse." As soon as the Formosan question was settled, General Kuroda and Count Inouye, escorted by several

1 Gaiko-Shiko, p. 65.

${ }^{2}$ Horei-Zensho (1868).

3 Ogawa, Diplomacy of the Meiji Era, p. 83.

4 Dip. Cor., 1867, part I, p. 426 . For. Rel., 1871, pp. 142 et seq. 
men-of-war, were despatched, in December, I875, to Korea, and, after many patient struggles, making the tactics of Commodore Perry and Townsend Harris their own, they finally succeeded in concluding a treaty of amity and commerce on February 26, $1876 .^{1}$

By this treaty, which has much political significance, it was declared that "Chosen [the Japanese name of Korea] being an independent state, enjoys the same sovereign rights as Japan," and the Chinese claim of suzerainty was formally ignored. The right of permanent embassy at Seoul and Tokyo was recognized. A promise was made to open two ports to Japanese trade. The consuls of Japan were permitted to reside at the open ports and administer justice to Japanese. The treaty also provided that the " official establishment of Japan" at Sorio, in Fusan, which was originally opened to commercial intercourse by Lord So, and the "practice of Saikensen," should be abolished, and that the Japanese trade at Fusan should be conducted in accordance with treaty regulations. Korea, by her trade regulations with Japan, ${ }^{2}$ prohibited the importation of opium, as Japan had done under the advice of Townsend Harris.

It was the policy of the imperial government, whose objects were commercial and not territorial, to secure the perfect independence of the Hermit Nation and to lead it into the light of modern civilization. This policy Japan made every effort to carry out. As soon as Fusan, Wongsan and Chemulpo were opened, Japanese merchants swarmed to the ports to trade. For purposes of administrative improvement and military training, numerous Japan-

${ }^{1}$ British and Foreign State Papers, vol. 67, pp. 530 et seq.

2 A supplementary treaty and trade regulations were concluded on August 27, 1876. Ibid., pp. 1269 et seq. 
ese advisers and instructors were employed by the Korean court. Youths were sent to Japan to be educated. The Japanese minister, seconding the efforts of the progressive party, advised the Korean king to grant the request of other nations for treaty relations. These innovations aroused the intense opposition of the conservative or antiforeign party, in which Taiwon-Kun (father of the king), and the Min family (from which the queen came), were the chief figures; and on July 23, I882, a mob, directed by a "scholar" of the orthodox school, named Pe Lo-kuan, attempted to seize the king and his ministers and frantically attacked the Japanese legation. Mr. Hanabusa, the Japanese minister, escorting the women and children of the legation, made his way with difficulty through the darkness to Chemulpo, whence, escaping by boat, he was taken to Nagasaki by the "Flying Fish," an English man-of-war. The Japanese government promptly despatched three cruisers, as an escort to Minister Hanabusa, to demand reparation. At the same time, China sent several warships, and sought to arbitrate the difference, in the capacity of protector of Korea. ${ }^{1}$ Japan, however, disregarding the pretensions of China, immediately entered into negotiations with the Korean government, and on July 27, I882, concluded the famous "Convention of Chemulpo." 2 By this convention, the Korean government was to punish the perpetrators of the recent outrage, to pay 550,000 yen as an indemnity, and to send an apology to Japan by a special embassy. More important still was the following clause:

Some Japanese soldiers may be kept in the Japanese legation

1 Ogawa, Diplomacy of the Meiji Era, p. 108.

2 The text of the Chemulpo convention is given in Ogawa, Diplomacy of the Meiji Era, p. II7; a general account is given in the New York Tribune, Oct. 2, 1882. 
as a girard, their station being built at the expense of the Korean government, but they are to be removed one year hereafter, if the Korean people shall preserve order, and the Japanese minister finds it unnecessary to keep the guard. ${ }^{1}$

China, however, still asserted her claim as protector of Korea. In the commercial regulations concluded between the two countries in September, 1882, it was declared that, "Korea having been, from ancient times, a tributary state, the canons of her intercourse in all matters with the government of China are fixed and need not be changed." ${ }_{2}^{2}$ Yet the United States in I882, Great Britain and Germany in I 883, and Italy and Russia in I884, established commercial and diplomatic relations with Korea by treaty, as with an independent state. ${ }^{8}$

After the outrage of 1882 , the Korean cabinet was once more organized by the progressive or pro-Japanese party and the Japanese troops were stationed at Seoul for the protection of their legation. China lost no time in counterbalancing the Japanese influence. Yen Shih-Kai, the most efficient colleague of $\mathrm{Li}$ Hung Chang, and a man of shrewd intellect, was appointed Chinese commissioner to Korea; Mr. Möllendorff, a German gentleman, who had once been personal secretary to $\mathrm{Li}$ Hung Chang, was recommended as adviser in foreign affairs; and 3000 Chinese soldiers were stationed at Seoul. ${ }^{4}$ These measures caused great anxiety at Tokyo. Steps were gradually taken to check

1 For. Rel., 1885, p. 343.

2 For. Rel., 1883, p. 173, contains text of treaty.

${ }^{3}$ The American treaty with Korea may be found in British and Foreign State Papers, vol. 73, p. 586; the British and German treaties, ibid., vol. 74, pp. 86 and 633; the Italian and Russian, ibid., vol. 75, pp. 195 and 308 .

4 Ogawa, Diplomacy of the Meiji Era, p. II6. 
the growth of Chinese influence, and to overthrow the Chinese claim of suzerainty. When the Korean envoys, Kim-ok-ki and Pok-Eiko, came to Japan to make the apology required by the Chemulpo convention, they were cordially welcomed by the people and the government, and were strongly advised, by prominent statesmen of Japan, to adopt western civilization in order to form a stable and independent nation. The envoys took home with them several Japanese civil and military advisers; and the Japanese government, with a view to encourage the Koreans to adopt modern institutions, returned on November II, I883, for the purpose of establishing an educational fund, a part of the indemnity paid by Korea for the outrage of $1882 ;{ }^{1}$ just as the United States had contributed a part of the Shimonoseki indemnity to education in Japan.

In the course of administration, collisions between the progressive and conservative parties (the pro-Japanese and pro-Chinese) at the Korean court became inevitable. The reform policy of the progressive party was so radical that the reaction toward the conservatives brought on, on December 5, I884, a coup d' état. The Japanese legation was again attacked by a Korean mob and Chinese soldiers. Thirty Japanese were killed and the legation was burned. Mr. Takezoye, the Japanese chargé d'affaires, barely escaped to Chemulpo. Count Inouye was immediately despatched to demand an explanation. The Chinese commissioner at Seoul claimed the right to arbitrate, by virtue of China's

1 Ogawa, Diplomacy of the Meiji Era, p. II9.

2 Taking advantage of the embroilment of China with France, the progressive party took a step towards sweeping reforms; they tried to kill Min Yong Ik, the prime minister, and to seize the government and control the person of the king. See Watanabe, Tobo-Kankei (Relations of the Eastern Nations), p. 132. For a detailed account of the coup d'état see For. Rel., 1885, pp. 332-342. 
suzerainty; ${ }^{1}$ but the representatives of Japan, declaring that the matter between Japan and Korea should be settled as between "two sovereign states, without any co-operation of a third power," concluded on January 9, I885, a convention ${ }^{2}$ by which Japan obtained substantially the conditions secured in 1882 .

Not only was the Chinese claim of suzerainty thus disregarded, but Count. Ito was sent to Tientsin to demand satisfaction from China for the part taken by Chinese soldiers in the attack on the Japanese legation at Seoul, and to provide, by diplomatic arrangement, against future aggressions by the Chinese in Korea. Negotiations between Count Ito and Earl Li were opened at Tientsin on April 3, I885, but were prolonged upon the question of the equal right of Japan and China to send troops to Korea in the event of a disturbance. ${ }^{3} \quad \mathrm{Li}$ Hung Chang insisted upon China's special privilege by virtue of her alleged suzerain power, but Count Ito threatened to break off negotiations unless the equal rights of Japan were recognized. Troubled by the English occupation of Port Hamilton and the FrancoChinese complication, the Chinese commissioner finally came to an understanding, and a convention was signed in April, I885. ${ }^{4}$ The contracting parties mutually agreed to withdraw their troops from Korea and not to send any armed force to the peninsula in the future without previously giving notice each to the other. $\mathrm{Li}$ also handed to the Japanese embassy a note of apology for the Chinese attack on

1 Ogawa, Diplomacy of the Meiji Era, p. I22.

2 British and Foreign State Papers, vol. 76, p. 574; For. Rel., 1885, p. 343 .

8 Ogawa, Diplomacy of the Meiji Era, p. 145.

4 British and Foreign Statc Papers, vol. 76, p. 297 ; For. Rel., 1885, pp. 563 et seq. 
the Japanese in Seoul. ${ }^{1}$ This was a diplomatic triumph for Japan, since she compelled China to recognize her equal right as to armed intereference in Korea and thus again ignored China's claims of suzerainty.

Nevertheless, after the coup d'état of 1884 , the Korean government was organized by the conservative party and Kim-ok-ki and Pok-Eiko sought refuge in Japan. YenShih-kai, the Chinese commissioner, became the most influential figure in Seoul, and the foreigners regarded him as "Mayor of the Palace." In spite of the Korean-Japanese agreement in regard to telegraphic construction, China, in I885, secured a concession to erect a telegraph line to Seoul and to control all telegraphs in the peninsula; and against this Japan vainly protested to the Korean government. ${ }^{2}$ In I888, the Chinese government more openly pressed its claim of suzerainty and tried to interfere with the sending of a Korean minister to the United States. President Cleveland, however, treated the Korean minister as the "representative of an independent state." 3 In I 889 the Korean government, without previous notice, issued a decree prohibiting the exportation of beans to Japan. This act resulted in a loss of 140,000 yen to Japanese merchants, who had made advances to the Korean producers. Japan immediately demanded damages, ${ }^{4}$ but the claim was not discharged until 1893, owing to the interference of the Chinese commissioner at Seoul, who controlled the customhouses in Korea. In April, I894, Kim-ok-ki, the Korean

1 Ogawa, Diplomacy of the Mciji Era, p. 149. The English text is given in For. Rel., 1885, p. 564 .

2 For. Rel., 1885, pp. 354 et seq. See also Watanabe, Tobokankei, pp. 269 et seq., for an account of telegraph concessions to Japan.

3 For. Rel., 1888, part I, pp. 222, 381, 443.

4 For a detailed account of the rice exporting question, see Watanabe, op. cit., pp. 265 et seq. 
refugee in Japan, who was looked upon by the Japanese as the only man to reform the corrupt administration of Korea, was induced by the treacherous Koreans to proceed to China to consult $\mathrm{Li}$ Hung Chang concerning reform measures, and was assassinated by a Korean at Shang-hai. ${ }^{1}$ This sensational crime was believed by the Japanese to have been effected by the connivance or with the aid of the Chinese, and it greatly stimulated the national indignation at the repeated acts of interference by China in the affairs of the peninsula.

The Chinese-Japanese War.-In the summer of 1894 , the Tonghak rebels ${ }^{2}$ rose in the province of Zenra, and, marching toward Seoul, got beyond the control of the government forces. On June 2 the government asked China to despatch troops to suppress the insurrection, whereupon Mr. Sukimura, the Japanese chargé at Seoul, learning what had been done, requested his government also to send troops, so as to be prepared for possible emergencies. ${ }^{8}$ Five days later the Chinese government, in accordance with the Tientsin convention of 1884 , informed Japan that it had despatched troops to the revolted district, but added: "It is in harmony with our constant practice to protect our tributary states by sending our troops." " Viscount Mutsu, who was then minister of foreign affairs, protested against the phrase " tributary states," and declared that the imperial government had " never recognized Korea as a tributary state of China." " Nor did Japan on this occasion wait for the ex-

${ }^{1}$ Tobokankei, p. 238.

2 The Tonghak was an anti-foreign association, especially hostile to the Roman Catholics. Full information as to the revolt is given in For. Rel., 1894, volume relating to the Chinese-Japanese war, pp. 5-17.

${ }^{3}$ Ogawa, Diplomacy of the Meiji Era, p. 158.

$4 \mathrm{Mr}$. Wang, Chinese minister at Tokyo, to Viscount Mutsu, minister of foreign affairs, Vladimer, The China-Japanese War, App. B, no. I.

s Ibid., no. 2. 
pulsion of her diplomatic representative, or the burning of her legation by Korean or Chinese soldiers, as in I 882 and I884. On the contrary, Mr. Komura, her chargé at Peking, was instructed to state that his government, in view of "the existence of a disturbance of a grave nature in Korea," proposed to send "a body of troops to the peninsula." 1 At the same time, a force of rooo men and a warship, the "Yayeyama," escorting Mr. Otori, the Japanese minister to Korea, left for Chemulpo, and arrangements were made to despatch several thousand more troops. Alarmed by Japan's action, China, on June 9, submitted the following protest:

Our country has despatched troops to Korea in compliance with an application from that country, for the purpose of assisting her to suppress the insurgents, and the measure is in accordance with the practice hitherto pursued by our country in protecting tributary states. Besides, the sole object being the suppression of insurgents in the interior, the troops are to be withdrawn as soon as that object is attained.

The sole object of your country in sending troops is evidently to protect the legation, consulates and commercial people in Korea, and consequently it may not be necessary, on the part of your country, to despatch a great number of troops, and besides, as no application therefor has been made by Korea, it is requested that no troops shall proceed to the interior of Korea, so that they may not cause alarm to her people. ${ }^{2}$

As the Chinese government thus ignored the equal treaty right of Japan to send troops to Korea, Mr. Komura was, on June 12, instructed to answer the Tsung-li-Yamên as follows :

The imperial government has never recognized Korea as a

1 Vladimer, The China-Japanese War, App. B, no. 3.

2 Ibid., no. 4. 
tributary state of China. Japan dispatched her troops in virtue of the Chemulpo convention, and in so doing she has followed the procedure laid down in the treaty of Tientsin. As to the number of troops, the Japanese government is compelled to exercise its own judgment. Although no restriction is placed upon the movement of the Japanese troops in Korea, they will not be sent where their presence is not deemed necessary. ${ }^{1}$

Meanwhile, the Tonghak rebellion was nearly over, but neither the Japanese nor the Chinese troops were withdrawn from Korea. ${ }^{2}$ Japan was in reality unwilling to withdraw her forces until she had secured such a measure of administrative reform as would enable Korea to preserve peace and order and to discharge her responsibility toward the treaty powers. With this end in view, Japan invited China, on June 17 , to take joint action to restore the peace of the peninsula, first, by suppressing the Tonghak rebels, and secondly, after the disturbance was over, by appointing commissioners who were to be charged with the following duties: "(a) The examination of the financial administration. (b) The selection of the central and local officials. (c) The establishment of an army necessary for national defence, in order to preserve the peace of the land." ' China declined the proposal, and, insisting upon non-interference with the internal administration of Korea, suggested, on the strength of the Tientsin convention, the immediate withdrawal of the troops from Korea." Japan, however, on June 22 , once more declared that it was impossible to withdraw her forces without securing the reforms

1 Vladimer, The China-Japanese War, App. B, no. 5.

${ }^{2}$ For. Rel., 1894, p. 21. "The king [of Korea] has begged the Chinese to leave, but they refuse to do so as long as the Japanese remain, and the latter positively refuse to leave until the Chinese go."

3 Vladimer, op. cit., App. B. no. 6.

4 Ibid., no. 7 . 
which she considered to be vital not only to the independence of Korea but also to her own commercial and political interests. ${ }^{1}$

In this dilemma, Japan gradually determined to assume the responsibility of her policy at any cost, and to solve the Korean question, which had so long been at stake, if necessary, without consulting the Chinese government. Mr. Otori, the Japanese minister at Seoul, was therefore authorized to do whatever he deemed requisite for the attainment of measures of reform. As a first step, he demanded of the Korean government a definite answer to the question whether Korea was "tributary to China" or an independent state. ${ }^{2}$ On June 30 he received an answer to the effect that Korea was an independent state, and he then immediately entered into negotiations. $\mathrm{He}$ advised the Korean government to reform its corrupt administration, both in respect of the organization of the government and the method of appointing officials; to regulate the tax system and exploit the national resources; to readjust the old system of courts of justice; to re-organize the military and police force on a national basis; and to adopt universal education and send abroad a certain number of young men for higher education. ${ }^{3}$ His advice was formally accepted, but he was requested to withdraw the Japanese troops. He declared this to be impossible till the reform measures had been carried out; and on July I9 he further demanded, (I) that the Korean government on the strength of the Chemulpo convention furnish an adequate building for the accommodation of the Japanese soldiers; (2) that it drive out the Chinese soldiers who were unreasonably despatched to Ansan; (3) that it allow Japan to guard with her troops

1 Vladimer, op. cit., App. B, no. 8.

2 For. Rel., 1894, p. 28.

3 For. Rẹl., 1894, p. 35. 
the military telegraph between Seoul and Fusan; (4) and that it abrogate all agreements with China which conflicted with the sovereign rights of Korea. ${ }^{1}$ The Korean government, which was still dominated by the conservative party at first refused to comply, but, in the presence of Japan's determined attitude, was practically helpless. Kim-YunSik and his colleagues of the progressive party were summoned to re-organize the king's cabinet; and Tai-Om-Kun, the father of the king, who was originally a conservative, but now favored reform, was invited to conduct the administration of the kingdom. Japanese troops were asked to guard the royal palace. On July 24 Korea finally abrogated her treaty with China and entrusted to the Japanese troops the expulsion of the Chinese forces occupying Ansan. ${ }^{2}$

The course of Japan tended to provoke China to immediate hostilities, but the Chinese government on July 3 requested Great Britain and Russia to use their influence to reconcile the existing differences. ${ }^{3} \quad \mathrm{Li}$ Hung Chang also specially asked, on July 8 , the Washington government to take the initiative in urging the powers to unite in a request to Japan to withdraw her troops from Korea. ${ }^{*}$ At the same time the British ambassador at Washington inquired "whether the United States would unite with Great Britain in an intervention to avert war between China and Japan." The United States replied that it "could not intervene otherwise than as a friendly neutral" and "could not join another power even in a friendly intervention." " A similar answer was made to the Korean and Chinese ministers at Wash-

1 Ogawa, Diplomacy of the Meiji Era, p. 175.

2 Ibid., p. 177. See also For. Rel., 1894, p. 56.

3 For. Rel., I894, p. 30.

4 Ibid.

รIbid., p. 38. 
ington. As a matter of fact, Mr. Dun, the American minister at Tokyo, "made a strong but friendly representation to Japan in the interest of peace." ${ }^{1}$ The United States, however, soon perceived that Japan could not be diverted from her purpose. It is said that from time to time the ministers of Great Britain and Russia at Tokyo separately requested the withdrawal of the Japanese troops from Korea, ${ }^{2}$ but their interposition did not go beyond diplomatic remonstrance.

Meanwhile, the relations between Japan and China became more and more strained. On the morning of July 25, three Japanese men-of-war had an engagement with several warships of China near the island of Sho-pai-oul. Two hours later the steamer "Kowshing," under the British flag, carrying Chinese reinforcements to Ansan, was fired upon by the "Naniwa," a Japanese man-of-war. The war thus began de facto, on July 25, without a declaration on either side, but declarations were formally issued by Japan and China on August I and 2, respectively. ${ }^{3}$ On August 20, Japan concluded a treaty of alliance with Korea in order " to expel the Chinese forces from the Korean kingdom, and to establish the independence of Korea." By this treaty, the Japanese forces were "to attack the Chinese" and the Koreans were " to exert the utmost efforts in all possible ways to facilitate the movement of the Japanese troops, and to prepare provisions for these troops." 4 This treaty was to expire as soon as Japan had concluded peace with China.

1 For. Rel., 1894, p. 39.

2 Ogawa, The Diplomacy of the Meiji Era, pp. I65 et seq. and $17 \mathrm{I}$ et seq.

8 Vladimer, The China-Japanese War, App. D.

4 For. Rel., 1894, p. 94; Ariga, La Guerre Sino-Japonaise, p. 277. 
The Peace of Shimonoseki and the New Commercial Treaty with China.-The Japanese were successively victorious at the battles of Ansan, Ping-Yang, and the Yellow Sea, and, while they were planning the invasion of Manchuria, China asked the great powers of Europe to intervene for the purpose of compelling Japan to conclude peace. On October 6, 1894, Great Britain invited the United States " to join with England, Germany, France and Russia in intervening between China and Japan," the basis of such intervention to be "that the independence of Korea should be guaranteed by the powers and that Japan should receive an indemnity for the expense of the war." ${ }^{1}$ The United States replied that, "while the president earnestly desires that China and Japan shall speedily agree upon terms of peace alike honorable to both, and not humiliating to Korea, he cannot join [the powers] in an intervention, as requested." Meanwhile, Port Arthur was besieged by the Japanese, and China again appealed, on November 3, to England, France, Germany, Russia and the United States for their assistance in establishing peace. ${ }^{2}$ The United States, acting independently, tendered its good offices to both belligerents. England also sounded Japan as to mediation. But the Japanese government, while appreciating these friendly overtures, declined to accept them, for the reason that the war had "not made sufficient progress to insure a satisfactory result of negotiation," since China had not yet found herself " in a position to approach Japan directly on the subject of peace." 3

Several days after the fall of Port Arthur, the Chinese government took the initiative in making overtures for

\footnotetext{
1 For. Rel., 1894, p. 70.

2 For. Rel., 1894, pp. 73 and 74-75.

3 For. Rel., 1894, p. 79.
} 
peace. Mr. Detring, commissioner of customs at Tientsin, came to Kobe, on November 26, as a special commissioner with a letter from the viceroy, $\mathrm{Li}$ Hung Chang, to Count Ito, the premier, and requested the governor of the Hyogo prefecture to obtain for him a conference with Count Ito as to the preliminaries of peace. After some delay, Mr. Detring was informed that his mission was not recognized, as he "was not properly accredited by the government of China." 1 While Japan was planning the assaults on Waihai-wei, Newchwang and Mukden, China informed the Japanese government, on December 23, through the American minister at Tokyo, that she had appointed Messrs. Chang In Hoon and Shao Yu Lien as plenipotentiaries to negotiate a peace. The Japanese government promised to appoint plenipotentiaries to meet them at Hiroshima, where the imperial general staff and the cabinet were then established. The Chinese plenipotentiaries arrived on January 31, I895, accompanied by Messrs. Wu-Ting-Fang and John W. Foster, and on the next day held their first conference with the Japanese plenipotentiaries, Count Ito, the premier, and Viscount Mutsu, minister of foreign affairs, at the prefectural building. Upon the exchange of powers, those of the Chinese plenipotentiaries were found to be inadequate, since they authorized them to conclude nothing, but merely to act ad referendum to Peking. ${ }^{2}$ At the next conference, therefore, Count Ito declined to proceed further, ${ }^{3}$ but intimated that, in case China should send representatives duly clothed with full powers, negotiations would be re-opened. The Chinese plenipotentiaries then returned home, having accomplished nothing.

At this stage of the war, Japan having been completely

1 For. Rel., 1894, pp. 83, 92, 93.

2 Ibid., p. Iоr.

${ }^{3}$ Ibid., p. 102. 
victorious, it was not to be expected that China could obtain peace without substantial sacrifices; and it was natural that Japan should wish her to appoint a plenipotentiary who would not only be invested with full power, but who would also be so influential as to be able to assume the responsibility of the negotiations. It is said that Count Ito hinted to the Chinese representatives, in private conversation, on the eve of their departure, that the presence of the viceroy Li Hung Chang was desirable. ${ }^{1}$ The strong fortress of Wei-hai-wei had fallen and Japan was concentrating her army and navy at the mouth of the Gulf of Pechili for a direct assault on Peking. Under these circumstances, the viceroy Li Hung Chang was sent out as ambassador plenipotentiary by China, with a suite of a hundred and thirty persons accompanied by Lord Li Ching Fang, an adopted son, and Messrs. Wu and Foster. On March 20 the first conference was held at Shimonoseki, and credentials were formally exchanged. Earl $\mathrm{Li}$ asked for an armistice as a preliminary to peace negotiations, but the conditions imposed by Japan were so onerous $^{2}$ that, at the second conference, he abandoned the subject and requested Count Ito to enter upon peace negotiations immediately. Unfortunately, while Earl $\mathrm{Li}$ was leaving the conference on March 24, he was fired upon and wounded by a Japanese fanatic named Koyama, who in his madness imagined he would benefit his country by assasinating "the strongest statesman of China." The imperial government and the people did their utmost to

1 Count Ito became acquainted with $\mathrm{Mr}$. Wu when he concluded the Tientsin convention with Earl $\mathrm{Li}$ in 1885 .

2 Ariga, La Guerre Sino'Japonaise, p. 250. The conditions were to surrender the fortresses of Tark, Tientsin, Shan-hai-kwan, with their munitions and provisions, to the Japanese troops, to put the TientsinShan-hai-kwan railway under control of military officers of Japan, and to bear all expenses of the Japanese force during the armistice. 
atone for this disgraceful act; the emperor sent his own physician, and the empress prepared with her own hands the bandages for the distinguished invalid; the governor and the chief of police of the prefecture were dismissed; and more than ten thousand letters of sympathy were sent in the course of a week from all parts of the empire to the stricken ambassador. Soon after the accident, the emperor ordered his plenipotentiaries to grant an armistice without the previous heavy conditions, and on March 30 an armistice to last twenty-one days was concluded for the provinces of Mukden, Pechili and Shan Tung. ${ }^{1}$ Meanwhile, the condition of Viceroy $\mathrm{Li}$ had so much improved that he informed Count Ito that he would resume negotiations with the aid of Lord Li Ching Fang, his adopted son.

[Japan's first draft of a treaty of peace was submitted on April I. ${ }^{2}$ China was asked to recognize the absolute independence of Korea; to cede that portion of the southern province of Shengking (Liao-Tung peninsula) lying between the rivers Yalu and Liao up to $4 \mathrm{I}^{\circ}$ north latitude, as well as Formosa and the Pescadores Islands; to pay an indemnity of three hundred million taels; to conclude a new commercial treaty based upon existing treaties of China with European nations; to grant to the Japanese in China the rights and privileges accorded to the most-favored nation until the new commercial treaty should come into force; to open seven new ports and four waterways to foreign trade; to modify the customs regulations and especially the "likin system;" and to grant to the Japanese the right freely to engage in "all kinds of manufacturing industries in China." As a guarantee of the faithful performance of the treaty, Mukden and Wei-hai-wei were to be temporarily occupied

1 Ariga, La Guerre Sino-Japonaise, p. 251.

2 Vladimer, The China-Japanese War, pp. 405-4II. 
by Japanese troops. Five days later, the Chinese plenipotentiary presented an elaborate memorandum, in which he stated his objections especially to the large indemnity, to the territorial cessions, and to the customs revision. ${ }^{1}$ The Japanese plenipotentiaries demanded a reply in a more " concrete form," and on April 9 the Chinese plenipotentiary submitted a counter-proposal by which Korean independence was to be guaranteed by both countries, the territorial cessions were to be limited to the Pescadores Islands and several districts in Shengking, the indemnity was to be reduced to a hundred million taels without interest, the Japanese troops were to be temporarily stationed only at Weihai-wei, and China and Japan were to agree to submit any subsequent disputes to the arbitration of a friendly power "in order to avoid future conflict or war." " In view of this counter-proposal, Japan next day modified her original draft in certain particulars. ${ }^{8}$ The cession of territory in Shengking was to be decreased by drawing a line through Fenghuang, Haichang and Yingkou; the indemnity was to be reduced to two hundred million kuping taels; the ports and waterways to be opened to foreign trade were to be reduced to four and two, respectively. Japan also agreed to occupy only Wei-hai-wei as a guarantee, but refused to admit into the treaty any clause concerning arbitration. On the following day an ultimatum was sent by Japan. Earl Li appealed to the Japanese for further modifications, but on April I3 Count Ito answered: "It only seems necessary for me to say in response to your Excellency's note, that

1 Vladimer, The China-Japanese War, pp. 4II et seq.

2 For the text of China's counter-draft of treaty of peace, see ibid., pp. 424 et seq.

8 Ibid., pp. 429-431.

- Vladimer, The China-Japanese War, p. 432. 
the demands which I handed to your Excellency on the roth inst., being final, are no longer open to discussion." 1

Only a few days of the armistice remained, and the Japanese forces were concentrated, under the command of Prince Komatsu, at the mouth of the Gulf of Pechili, ready for the attack on Peking. Under such circumstances, Viceroy $\mathrm{Li}$ could do no more for his emperor and his country than accept the Japanese ultimatum, and the treaty of peace was signed at Shimonoseki on April I7, $1895 .^{2}$ The ratifications were to be exchanged at Chi-fu; but, /on April 22, Russia, France and Germany, acting in alliance, advised Japan to restore the whole territory of the Liao Tung peninsula, as " the Japanese occupation of that territory not only endangered the existence of the Chinese capital and of Korean independence, but would upset the peace of the Orient." ${ }^{3}$ The formidable squadrons of the three great powers were concentrated in the north of China, and prepared for an emergency. Excited Japanese officers insisted on forcibly resisting the interference of the triple alliance, while idealistic diplomatists proposed to submit the territorial question to an international conference of the great powers of Europe and America. But the naval forces of Japan, after hard wrestling with China, were unable to cope with the fresh squadron of the three powers, and an international conference would create another complication. The only practical answer was to accept the advice of the allies, and on May 3 Japan assured them that she was ready to renounce the permanent possession of the Liao-Tung

1 Vladimer, The China-Japanese War, p. 436.

2 British and Foreign State Papers, vol. 87, pp. 799 et seq.

3 Note of the Russian minister at Tokyo to the Japanese minister of foreign affairs, on April 23. Ogawa, Diplomacy of the Meiji Era, p. 213. See also Leroy-Beaulieu, The Awakening of the East, p. 247. 
peninsula. ${ }^{1}$ By a separate convention, China gave to Japan an additional indemnity of $30,000,000$ taels in consideration of the restoration. ${ }^{2}$ In the light of subsequent events it is matter for regret that Japan did not take advantage of the situation to exact from China a pledge that the Liao-Tung peninsula should not be occupied by any other power, especially as excellent precedent for such a course was provided by the pledge exacted from China by Great Britain upon the occasion of the evacuation by the latter of Port Hamilton. ${ }^{3}$ Had such a pledge been exacted one of the principal causes of the Russo-Japanese conflict would have been removed.

In accordance with the terms of the Peace of Shimonoseki, a new commercial treaty between Japan and China was signed at Peking on July 21, 1896." Its most significant feature was that the reciprocal form of the old treaty was replaced with the unilateral form. The new treaty recognized the consular jurisdiction of Japan in China and guaranteed to Japan most-favored-nation treatment in all that concerns consular jurisdiction, commerce, industry and navigation, but did not guarantee similar treatment to Chinese in Japan, except as to diplomatic agents.

Although the legitimate fruits of the war were snatched from Japan by the interference of the continental powers of Europe, the conflict produced important results. China was compelled to recognize Korean independence, ${ }^{5}$ which had

1 Ogawa, Diplomacy of the Meiji Era, p. 227. See also Imperial Rescript of May 10, concerning the restoration of the peninsula, British and Foreign State Papers, vol. 87, p. 805.
2 Ibid., p. I195.
3 Infra, p. 186.

4 Ogawa, Diplomacy of the Meiji Era, vol. 88, pp. 473 et seq.

- China recognizes Korean independence by the first article of the Shimonoseki treaty. Korea also concluded a treaty of amity and commerce with China on an equal footing on September I1, 1899. For. Rel., I899, p. 492. 
been at stake for two decades. Significant steps were also taken towards opening China to the world's commerce, especially by securing access to new ports and to waterways extending into the interior. The privilege was obtained of hiring or renting warehouses for the storage of articles purchased in the interior, and of transporting imported merchandise into the interior "without the payment of any taxes or exactions whatever." Foreigners were also permitted to "engage in all kinds of manufacturing industries in all the open cities, towns and ports of China," and it was stipulated that all these manufactured articles should "enjoy the same privileges and exemptions as merchandise imported by foreigners into China."

Treaty Relations with Spain.-Treaty relations between Japan and Siam were first established in 1887 when Prince Devawongse visited Tokyo and concluded a declaration with Mr. Aoki, vice-minister of foreign affairs. ${ }^{1}$ By this declaration, provision was made for the exchange of ministers and the establishment of consulates, and for the encouragement of commerce and navigation. As both contracting countries then strongly aspired to judicial autonomy, and to the development of civilization on western lines, their treaty relations were somewhat different from those formed with China and Korea. The declaration did not recognize consular jurisdiction, but provided that, until a " complete convention" should be made, the subjects of each power should have in the dominions of the other full security of person and of property, and the right to "be treated in a fair and equitable manner."

A new treaty was concluded in 1899; and notwithstanding the fact that, while Japan had abolished foreign consular jurisdiction, Siam still retained it, the new treaty re-

1 British and Foreign State Papers, vol. 79, p. 319. 
cognized the territorial law of both countries. ${ }^{1}$ By a separate agreement, however, Japan secured consular jurisdiction in Siam, except as to the laws of succession and marriage, until the codification of the laws of that country should be completed. ${ }^{2}$ While Japan does not concede most-favored-nation treatment in the case of the Chinese and Koreans, the new treaty with Siam stipulates for reciprocal most-favored-nation treatment in commerce and navigation. A striking feature of the treaty is a provision for arbitration, in case the contracting parties cannot agree as to the interpretation of the treaty provisions.

Japan's readiness to recognize the judicial autonomy of Siam may serve to encourage the Siamese in their desire to enter into the "comity of nations."

${ }^{1}$ British and Foreign State Papers, vol. 90, pp. 66 et seq.

2 Ibid., pp. 70 et seq. 


\section{CHAPTER VIII}

\section{The Far Eastern Question, I895-I900}

Russo-Japanese Rivalry in Korea.-As soon as the war with China was over, Japan entered into international politics in association with western powers; and she at once began to play, especially with Russia in Korea, a significant part in the drama.

After the Crimean War, Russia, checked in her designs upon the Ottoman Empire and thus prevented from obtaining an outlet to the Mediterranean, determined to push her way to the Pacific. She secured, by the treaty of Peking in I860, the possession of the Pacific coast of Manchuria from the Amur River to Vladivostock and the Korean frontier; ${ }^{1}$ and in 1875 she finally acquired Saghalien Island from Japan in exchange for the Kurile Islands. ${ }^{2}$ After her approach to the Mediterranean through the Balkan peninsula had been definitely blocked by the treaties of Paris, London and Berlin, for the reason that the great powers considered her advance in that direction dangerous to the integrity of the Ottoman Empire and to the balance of power in Europe as well, and after her route to the Persian Gulf and Indian Ocean through Persia or Central Asia had been closed by England, Russia decided to con-

1 British and Foreign State Papers, vol. 53, pp. 970 et seq.

${ }^{2}$ Dip. Cor., 1867, part 2, pp. 61 et seq. For. Rel., 1875, p. 1065. See also Martens, Traités, vol. ii, p. 582. Russia laid claim to the island of Saghalien in 1867 , and secured possession of it by the treaty of 1875 .

4I7] 
centrate all her energies upon establishing her foothold on the Pacific Ocean. The Russian ministers at Peking and Seoul therefore moved hand in glove with Li Hung Chang, Yen-shi-gai, and Möllendorff ; and this was true prior to the British occupation of Port Hamilton, a Korean Island, which had been, in I885, occupied by the English government " in order to anticipate the Russian seizure" of Port Lazareff. ${ }^{1}$ But Great Britain evacuated the island in I887 on the strength of an assurance from China that "the Russian government would not occupy Korean territory under any circumstances." 2 In I89I, Russia commenced her gigantic undertaking for the construction of a trans-Siberian railway east to Vladivostock. She was not, however, satisfied with Vladivostock as her outlet on the Pacific, for the port is ice-bound more than half the year. Seeking a better terminal in the extreme Orient which might be free from this natural restriction, Russia cast longing eyes upon Korea and Manchuria. She secured from the Korean government, in 1893, an overland telegraphic connection between Korea and Siberia. ${ }^{3}$ Had Japan, as the result of the Shimonoseki treaty, obtained the Liao-Tung peninsula, fortified Port Arthur and Talienwan, and secured a free hand for the preservation of Korean independence, it would have been next to impossible for Russia to obtain a satisfactory outlet on the Pacific coast. It was therefore inevitable that Russia should come more and more to interfere in the Korean as well as in the Manchurian question.

Japan fought with China mainly for the reform of the corrupt administration of Korea, which was endangering Korean independence and menacing the interests of the

1 Cordier, Histoire des relations ae la Chine, vol. iii, p. 3.

2 Parliamentary Papers, China no. I (1887).

3 Curzon, Problems of the Far East (edition of 1896), p. 212. 
world; and for the carrying out of her policy Japan had of course expected to assume the unavoidable responsibility. After the Chino-Japanese war broke out in July, 1894, numerous laws were introduced in Korea, and a "council of state" was instituted for the preparation of reform measures. On New Year's day of I895, Li-Hsi, king of Korea, promulgated at the Ancestral Temple the fundamental law of the country, ${ }^{1}$ which was regarded as a brief summary of its constitutional system, just as the Mikado had proclaimed the " imperial oath of five items" on the eve of the Restoration of 1868 . By this law, Korean independence was again declared; the ruling power was affirmed to belong to the king alone, with the advice of his ministers and council; all administrative measures were to be executed according to law; the old feudalism and social classes were to be abolished; a new educational system was to be introduced. Hitherto, the queen and her relatives, the Min family (the old pro-Chinese party), had often interfered with the king and prevented reforms by their reactionary influence. The constitution, therefore, specially provided that "the queen and her relatives must not oppose these." Count Inouye, one of the founders of modern Japan, was sent to Korea as advisory commissioner. Pok-Eiko, a Korean refugee who had been in Japan since the insurrection of 1884 , was now recalled and appointed to the post of minister of the interior. Numerous laws and ordinances regulating the details of every branch of the administration, including education, taxation and courts of justice, were issued, but the execution of this "busy legislation" was poorly performed. The reform party, led by Pok-Eiko, soon came into conflict with the Min party and the queen, and after plots and

1 An English translation is given in Curzon, Problems of the Far East, p. 375. 
counter-plots, Pok finally fled to Japan for safety. Meanwhile Count Inouye was replaced by Baron Miura, a man of decision and executive ability, but who lacked diplomatic tact, and Tai-Om-Kun, the father of the king, was once more called to the regency. The reform party, backed by new and active advisers and a strong regency, now undertook sweeping reforms, and, as the result of a plot led by BokuSen, the queen and her colleagues, who obstinately opposed all reform measures, were killed.

Russia, who had been watching for an opportunity to interfere in Korean affairs, professed to regard the recent plot as the treacherous work of the Japanese Soshi, ${ }^{1}$ and exaggerated the insecurity of the Korean royal family. The conservative party, backed by Russian influence, again became active and now persuaded the king to shake off the Japanese influence and to depend upon Russian support. A secret attempt to remove the throne to the Russian legation had been prevented in December, 1895, by the national guard. Subsequently, the guard was sent to the revolted district in northern Korea. Taking advantage of its absence, the conservative party, on February II, I896, perpetrated a riot at the palace. Tai-Won-Kun was killed, the king and the heir-apparent were taken from the palace and were received in asylum at the Russian legation, which was guarded by Russian marines who had landed the day before at Chemulpo. The cabinet ministers were declared guilty of treason and a new cabinet was organized exclusively of the pro-Russian party led by Min-Chong-Mok. ${ }^{2}$ The result of the recent émente was that all reform measures and improvements, undertaken by Japanese advice, were utterly annulled. To prevent the further encroachment of Russian influence in Korea, there was no other course left

1 A sort of Japanese outlaws. $\quad 2$ Annual Register, 1896, p. 35 I. 
open to Japan than that of negotiation with her rival. The Komura-Waeber memorandum was therefore conciucled at Seoul in May, 1896, and the Yamagata-Lobanow protocol at St. Petersburg, in July, when Marquis Yamagata attended the Czar's coronation. ${ }^{1}$ By these agreements the contracting parties engaged that their representatives should give "friendly advice" to the Korean king to return to his palace from the Russian legation, while the Japanese representative was to give an assurance that the most conplete and effective measures would be taken for the control of the Japanese Soshi at Seoul. Japan was also required to limit the number of her troops in Korea to a thousand, for the protection of her telegraph line between Fusan and Seoul and of her settlements in the capital and in the open ports of Fusan, Wongsan and Chemulpo. On the other hand, Japan recognized the right of Russia to keep troops in Korea as well as her concession to construct a telegraph line between Seoul and Siberia. Russia also obtained the right to advise Korea concerning financial and military matters as freely as Japan.

It must be frankly admitted that the Japanese advisers, in their reforming zeal, made a gross error in introducing into Korea radically new institutions for which there was no desire and which conflicted with established customs and traditions. Not only are the Koreans less adaptable than the Japanese, but they are, on the contrary, peculiarly impervious to new ideas. Even the Japanese assimilation of modern institutions was the work of several decades. It is no wonder then that the radical reforms attempted in Korea provoked antagonism to Japan among the conservatives and finally opened the way to the active interference of Russia in Korean affairs.

${ }^{1}$ British and Foreign State Papers, vol. 88, pp. 471-472. 
King Li-Hsi, after receiving many petitions from the people, left the Russian legation for his palace in February, I897, but the progress of Russian influence was not checked. M. Speyer, the new Russian minister at Seoul, is said to have obtained a promise from the Korean government that the Korean army should be trained by Russian instructors, in spite of the objections of the king, who feared that international complications might result. ${ }^{1}$ Not only did Russia seek military control, but she also sought to take charge of the finances of Korea. A secret agreement is said to have been concluded on November 5, I897, under which M. Alexieff, the secretary of the Russian legation, was to be appointed financial adviser to the Korean government, and Mr. Brown, a British subject, was to be dismissed from his office in the custom house. ${ }^{2}$ At the same time, the so-called Russo-Korean Bank, a branch of the Russo-Chinese Bank, was established at Seoul. So pervasive indeed had Russian influence become that Korean independence seemed to be little more than a name.

Meanwhile, Japan, though she had failed in her attempted reforms, was quietly and patiently preparing to oppose the Russian domination. In 1897 an extraordinary increase was made in her budget for the army and navy. ${ }^{3}$ On the other hand, her subjects, in order to gain a firm footing in the peninsula, were developing the commercial and industrial privileges which had been granted by the various treaties. At the same time Great Britain immensely increased her fleet in the Orient, as a counter-check to Russian activity in north China, and, when Mr. Brown was dismissed

1 The Far East (a Japanese periodical published in English), vol. ii, p. 533 .

2 Ibid., p. 725. See also Annual Register, 1897, p. 362.

3 Annual Register, 1897, p. 363. 
from the customs service, a part of the British squadron appeared at Chemulpo. There was also much speculation in the Japanese as well as in the English press as to the possibilities of an Anglo-Japanese alliance, while the Russian navy was concentrating in the Gulf of Pechili prior to the occupation of Port Arthur. No sooner, however, had Russia obtained a lease of the Kwan-Tung peninsula, including Port Arthur and Tai-Lien-Wan, from China, in March, I898, than she prudently determined to abandon her intervention in Korea "in order not to add the powerful support [of Japan] to that of England." ${ }^{1}$ The request of the Korean government for the withdrawal of the Russian financial adviser and the Russian military instructor was heeded, and even the Russo-Korean Bank was closed ; ${ }^{2}$ and on April 25, I898, a very satisfactory protocol between Japan and Russia was signed at Tokyo. ${ }^{3}$ The contracting parties, definitely recognizing "the sovereignty and entire independence of Korea," agreed not to interfere in the affairs of that country, nor to take any steps to nominate military instructors or financial advisers without a previous mutual understanding. Russia especially pledged herself not to interfere with the peculiar development of the commercial and industrial relations between Japan and Korea, thus giving Japan a free hand, so far as her economic interests in Korea were concerned. As a result of this favorable agreement, Japanese syndicates were enabled to obtain from the Korean government a definite grant of the concession of the Fusan-Seoul railroad, a first claim to

1 Leroy-Beaulieu, The Awakening of the East, p. 272.

2 The Far East, 1898, vol. iii, p. 332.

${ }^{3}$ Gaiko-Jiho (Revue Diplomatique), Tokyo, vol. i, no. 5, p. 27. For. Rel., 1898, p. 473. 
which they had previously obtained in $1894 .^{1}$ They also bought up the Seoul-Chemulpo concession which had originally been granted to Mr. Morse, an American citizen. ${ }^{2}$

The coincidence of the Russian recession from Korea with the Russian occupation of Port Arthur would seem to indicate that Russia then thought that she could secure freedom of action in the Pacific by the fortification of Port Arthur and the building of the Manchurian railway. From a strategic point of view, however, her line of water communication between Vladivostock and Port Arthur was obviously unsafe without a naval station or a coal depot on the Korean coast, since it could at any moment be cut by Japan, who was energetically increasing her naval force and who had fortified the strait of Tsushima as a wedge in the Russian waterway. Russia therefore renewed her activities in Korea, but under the guise of private transactions in order to avoid the protest of Japan. On May I, I899, the Korean government opened the harbor of Masanpho, thirty miles from Fusan. Masanpho is one of the finest harbors in Korea, and is protected by Koje Island, facing Tsushima Strait. Five days after the opening of the harbor, M. Pavloff, the Russian representative at Seoul, while on his way to Russia on leave, met at Masanpho Admiral Makaroff, the famous strategist, and after a thorough survey of the coast and harbor they selected a large tract on the shore-a most available strategic site-which $M$. Pavloff informed the local authorities would soon be purchased by the Russian Steamship Company for a dock and coaling station. Before the legal formalities were completed, the owner of the land sold it for a higher price to Japanese. The Russian

1 Rockhill, Treatics and Conventions with, or concerning, China and Korea (1894-1904), pp. 453 et seq.

2 Ibid., pp. 450 et seq. The text of the original contract between $\mathrm{Mr}$. Morse and the Korean government is given. 
government demanded of the governments of Japan and Korea that the land be restored to the original contractor, ${ }^{1}$ but they replied that they had no right to interfere in legitimate transactions between Japanese and Korean subjects. ${ }^{2}$ The resulting irritation gave rise to persistent rumors of war in the European press as well as in the Japanese. Fortunately, however, the year I899 passed away without a collision.

M. Pavloff returned to Seoul on March 19, 1900, and presently demanded from the Korean government the cession to the Russian Steamship Company of "Atkinson's Point," commanding the entrance of Masanpo harbor. At the same time he required that Korea should hold on to Koje Island, so as to keep it out of the counter-occupation of the Japanese. Meanwhile the Russian Rear Admiral Hildebrand, came to Chemulpo with several men-of-war. His appearance was regarded by the Japanese as a repetition of what preceded the Russian occupation of Port Arthur, and again there arose a wild rumor of war; but, as the Korean government, acting on Japan's advice, remained firm, Russia somewhat modified her terms, and agreed to take a lease within the foreign settlement of Masanpho, Korea giving her pledge not to alienate Koje Island. ${ }^{3}$ Russia is said further to have obtained the right to use her leased lot for a coaling station and a naval hospital for her Pacific squadron, ${ }^{4}$ but this did not necessarily impair the sovereign rights of Korea, nor the interests of Japan or of any other treaty power, since similar concessions might be obtained by the other powers within the foreign settlement.

${ }^{1}$ Revue française de l'étranger et des colonies, 1900, vol. 25, p. 396.

${ }^{2}$ Gaiko-Jiho (Revue Diplomatique), Tokyo, 1900, no. 26, p. 45.

3 International Year Book, vol. of 1900, p. 255.

4 London Times, May 5, 1900, p. 5, Peking correspondence. 
The other powers, however, would not have kept silence, had Russia fortified the leased territory or stationed her forces therein.

The Struggle of the Great Powers in China-Spheres of Interest.-The Liao-Tung peninsula, being barren land, is economically valueless, but it is of vital importance to Japan for the preservation of Korean independence against the possible encroachments of China or Russia, because it includes the magnificent naval station of Port Arthur, and the fine port of Tailien-Wan, which is situated in a dominant position in the Yellow Sea between China and Korea. For this reason, Japan had sought to obtain the Liao-Tung peninsula by the treaty of Shimonoseki; but she was forced by Russia, France and Germany to restore it on the ground that her possession of it "would be detrimental to the lasting peace of the Orient." Russian interference would be theoretically justified so long as it respected this principle, but in reality its aim was to obtain the peninsula for Russia herself. France and Germany supported her against Japan on account of political relations in Europe, and, wishing " to gain the good graces of the czar," " they both answered all proposals which came from St. Petersburg favourably." Besides, they seem also to have expected handsome concessions from China as a reward for their attitude. Their action produced a great change in the situation in the Far East. The preponderant influence previously held by Great Britain in China was superseded by that of Russia, France and Germany; and, while the antagonism between Russia and Japan became more pronounced the relations between Great Britain and Japan began to grow closer.

After the war with Japan, when the Chinese government was confronted with the question of how to pay the

${ }^{1}$ Leroy-Beaulieu, The Awakening of the East, p. 248. 
heavy indemnity imposed by the treaty of Shimonoseki, Russia seized the opportunity to strengthen her position in China by doing a favor to the " sick man." Herself heavily burdened with a foreign debt of more than $£ 240,000,000$, she could not directly make an adequate loan to China; but, under the able management of the "financial diplomat," M. de Witte, then minister of finance, the Russian government, on June 24, I895, gave its guarantee to a syndicate, mainly composed of French financiers, to furnish China a four per cent loan of $400,000,000$ francs. ${ }^{1}$ The services repeatedly rendered by Russia to China could not fail to be appreciated by the latter. Count Cassini, the foremost diplomat of the czar, is said to have succeeded, while Russian minister at Peking, in concluding a secret arrangement, known as the "Cassini convention," between the RussoChinese Bank and China, for the construction of a railway in eastern China. According to this agreement, which is said to have been confirmed when Li Hung Chang attended the czar's coronation in $1896,{ }^{2}$ Russia was to prolong the trans-Siberian railway into the "three Eastern Provinces" of Manchuria (art. I), and to provide the funds in case China built a branch line from Kirin to Newchwang via Mukden (art. 3). ${ }^{8}$ China was to " follow the Russian rail-

1. The details of the loan and the text of the contract are given in Cordier, Histoire des relations de la Chine avec les puissances occidentales, vol. iii, pp. 305-308.

2 Krausse, Russia in Asia, p. 183 .

8 The French text is given in Cordier's work, pp. 343 et seq.; the English text in Drace, Russian Affairs, pp. 663 et seq. According to Professor Cordier, the alleged convention consisted of two documents, one relating to the railway in Manchuria, negotiated between the RussoChinese Bank and China, the other to Kiao-Chou Bay, between $\mathrm{Li}$ Hung Chang and Prince Lobanoff at St. Petersburg. These two became confused and were generally known to the public as the "Cassini convention." See Cordier, ibid., pp. 347-348. 
way regulations" in case she built the line from Shan-haikwan to Port Arthur through Newchwang and Chinchou (art. 4). The railways to be built by Russia in China, and the Russian subjects engaged in building them, were to be protected by the local civil and military officials; although in the barren and sparsely inhabited territory where the Chinese authorities were not able to afford proper protection, Russia was to "be allowed to place special battalions of horse and foot soldiers at the various stations," (art. 5). The Russians, with the co-operation of the Chinese, were to be permitted "to exploit and open any mines" in the three provinces (art. 7); and Russian officers were to be engaged to instruct the Chinese forces in the "Eastern Provinces" (art. 8). The port of Kiao-Chou, in the ShanTung province, was to be leased to Russia for fifteen years, should Russia enter into hostilities with any power on the Asiatic continent (art. 9). China was to rebuild the forts at Port Arthur and Talien-Wan, while Russia was to help protect them against encroachment by other powers; China, besides, was not "to cede them to any power," but was to grant to Russia the right "to concentrate her land and naval force within the said ports," in case she became involved in war (art. IO). As the result of this agreement, the Chinese Eastern Railway Company ${ }^{1}$ was formed by the Russo-Chinese Bank, and was authorized to construct a line across Manchuria, connecting the branch of the TransSiberian Railway from the Baikal region directly with Vladivostock, and thus reducing the originally estimated length of the railway by 568 miles. $^{2}$ Most significant of all, however, was the provision that all Russian imports by the

1 The statutes of the Chinese Eastern Railway Company are given in British and Foreign State Papers, vol. 88, p. 773.

2 Pierre Leroy-Beaulieu, The Awakening of the East, p. 72. 
railway should be admitted at a rate of duty one-third less than that imposed at Chinese seaport custom-houses.

For her services in the triple intervention of 1895 , France obtained from China, by the conventions signed at Peking on June 20 of the same year, the extension of her commercial concessions on the frontier of Cochin-China and certain concessions as to the boundary in that quarter. ${ }^{1}$

Germany for a time kept quiet. She apparently thought that her services could not be requited within the ordinary bounds of diplomacy, and awaited an opportunity to demand a liberal reward. On the first of November, 1897, a Chinese mob attacked the German church at Yenchow, in the Shan-Tung province, and murdered two missionaries. This event furnished an occasion for the disclosure of Germany's commercial and naval ambitions in the Far East. In due time a German squadron commanded by Prince Henry, a brother of the Emperor William, entered the KiaoChau bay and occupied the place. The German example was quickly followed by other powers. Russia, in December, I897, occupied Port Arthur and Tailien-Wan. Germany, on March 6, 1898 , concluded a convention for the occupation of Kiao-Chau, and on March 27 a similar convention was made by Russia as to Port Arthur and TailienWan. Kiao-Chau bay and the adjacent territories were, by the first convention, leased to Germany for a term of ninety-nine years with the right to construct fortifications, to establish a naval and coaling station, and to build a dockyard. Germany further obtained the concession of a preferential right to construct railways and to exploit mines throughout the Shan-Tung province. ${ }^{2}$ Russia obtained a

${ }^{1}$ Leroy-Beaulieu, op. cit., p. 259. For the text of the convention, see Cordier, op. cit., vol. iii, pp. I63 et seq.; Rockhill's edition, pp. $2 \mathrm{I}$ et seq.

2 The full German text is given in Das Staatsarchiv, vol. 6r, pp. I et seq. See also Parl. Papers, China no. I (I899), pp. 69 et seq. 
lease of Port Arthur, Tailien-Wan and the adjacent waters for twenty-five years, with the right to erect fortifications and to establish naval and military stations. Moreover, the Russo-Chinese Bank was authorized to construct a branch line of the Trans-Siberian Railroad through Manchuria to Tailien-Wan and to Port Arthur. ${ }^{1}$ Following the example of Russia and of Germany, France, on April Io, I898, secured a lease of Kwang-chow-Wang, a bay on the south coast of China, for ninety-nine years as a naval station; the right to construct a railway connecting Tonquin with Yannan-fu by the Red River; a pledge of the nonalienation of the three southern provinces and the appointment of a French subject as the director general of the Chinese post office. ${ }^{2}$

Toward these transactions, Great Britain assumed a selfdefensive attitude, although, in her opposition to Russia and France, she co-operated to a certain extent with Germany and Italy. To counterbalance the loan policy of Russia of I 895, Great Britain, in I896, gave her guarantee to the Hongkong and Shanghai Bank and the Deutsch-Asiatische Bank to enable them to float another Chinese loan of $\mathfrak{f}_{1} 6,000,000 .^{8}$ She also obtained by a convention of February 4 , I897, certain important modifications of the boundaries of Burma and Thibet. ${ }^{4}$ Great Britain, though she has ever sought to maintain the balance of power against Russian encroachments in the Far East, never more openly displayed her traditional policy than in the case of the

1 Parl. Papers, China no. I (1899), pp. 128 et seq.

2 Ibid., p. 12. The full French text is given in Cordier, op. cit., vol. iii, pp. 370 et seq.; its English translation in Rockhill's edition, p. 55.

3 Consular Reports of the United States, October, 1899, p. 328; Cordier, op. cit., vol. iii, p. 303.

4 Parliamentary Papers, Treaty Series, no. 7, 1897; Rockhill's edition, pp. 40 et seq. 
Russian occupation of Port Arthur. Recognizing the fact that Russia, in possession of a station like Port Arthur, in the Gulf of Pechili, near the Chinese capital, could easily overawe the Peking government and menace the interests of the other treaty powers in Manchuria, she immediately protested against the proposed acquisition. Russia pleaded that Port Arthur had been "temporarily lent" to her as a "winter anchorage for Russian vessels," 1 but meanwhile, as the London Times reported, demanded from China the same rights over Port Arthur and Tailien-Wan as Germany had secured over Kiao-Chau, and threatened that, if an agreement was not signed within five days, to move her troops into Manchuria. ${ }^{2}$ Alarmed by this report, the British foreign office demanded information as to what was going on. Count Mouravieff answered that Russia was negotiating for the lease of Port Arthur and Tailien-Wan, as "the possession of a port on an ice-free coast was a matter of vital importance to Russia," and that a part of Tailien-Wan would be open to foreign trade. ${ }^{3}$ The British government of course did not object to Russia's acquiring an ice-free harbor on the Pacific, so long as it remained a free commercial port like Hongkong; but the " military occupation or fortification of Port Arthur or any other harbors in the Gulf of Pechili " by Russia was another matter. Sir Claude Macdonald, British minister at Peking, warned China not to make such a concession, while Sir Nicholas O'Connor lodged a protest at St. Petersburg. But it was all in vain. Russia insisted and China yielded." The "balance of power in the Gulf of Pechili," declared the

1 Parliamentary Papers, China no. I (1898), pp. 9, ro and I2.

2 London Times, March 7, 1898.

3 Parliamentary Papers, China no. I (1898), p. 43.

* Ibid., p. 53. 
Marquis of Salisbury, "is materially altered by the surrender of Port Arthur by the Yamen to Russia;" ${ }^{1}$ but, being unwilling to go to war, the British government, with a view to counteract the new Russian advantage, demanded of China a similar concession, and, by advancing the money to pay off the Japanese war indemnity, secured on April 3, I898, a lease of Wei-hai-wei, which was then occupied by Japanese troops as a guarantee. ${ }^{2}$ Meanwhile, the French squadron had been manoeuvering near the harbor of Shanghai; but England had quietly secured from China on February 9, 1898, a promise not to alienate the rich valley of the Yang-tsze-Kiang, ${ }^{3}$ thus anticipating the demands of other powers. English influence, however, was also endangered in the south of China, where the fortification of Kwang-Chow Bay by France was likely to endanger HongKong. To meet this danger, Great Britain on June 9, I898, concluded the so-called "Hong-Kong Extension Agreement," by which China granted a lease for ninety-nine years of 400 square miles of territory in the peninsula of Kowloon, immediately opposite to Hong-Kong, on the same terms as the French lease of Kwang-Chow Bay. ${ }^{4}$ What Great Britain desired in China was to preserve the Celestial Empire as an open market for the world's commerce, in which all nations might have fair play; and if this policy was put in jeopardy or hampered by exclusive concessions, or by the predominant influences of particular powers, the only thing remaining for England to do was either to fight or to make counter-demands for similar concessions or for the exercise of a like influence. During the early part of

1 Parliamentary Papers, China no. I (1898), p. 54.

2 State Papers, vol. 90, p. 16.

3 Parliamentary Papers, China no. 2 (1898).

4 British and Foreign State Papers, vol. 90, p. 16. 
I898, when the continental powers of Europe were pursuing exclusive aims in China, the " integrity of the empire," an "open door to the world commerce," and " equality of opportunity" were the watchwords in the House of Commons, ${ }^{1}$ while demands for counter-concessions and for the maintenance of the balance of power in Pechili were advo cated by Lords Salisbury and Kimberley, and by Messrs. Balfour and Curzon.

The policy of Japan, up to the Chino-Japanese war, seems to have been to keep aloof from European entanglements in the Far East. In I884, when China was involved in the Korean complications with Japan and in the Tonking dispute with France, France offered to form an alliance with Japan against China, ${ }^{2}$ but Japan politely declined. China, however, pursued a different course, and, during the war with Japan, introduced European political intervention into the Orient. As the result of the triple intervention of 1895 , Japan's policy of aloofness became utterly untenable. The European powers having acquired important footholds in the Orient, it became impossible to maintain the principle of "Asia for the Asiatics," and the only course left open to Japan was to co-operate with the powers having views similar to her own, in order to preserve the balance of power against disturbers. Japan thus naturally became desirous of co-operating with Great Britain, and welcomed the request for the evacuation of Wei-hai-wei when England obtained the lease of it. ${ }^{3}$ At the same time there was much discussion of the possibility of an Anglo-Japanese alliance in the native press. ${ }^{4}$

1 See speech of Mr. Balfour, in the House of Commons, London Times, April 6, 1898, pp. 8-9.

2 Ogawa, Diplomacy of the Meiji Era, p. 123; Curzon, The Far East, p. 210.

${ }^{3}$ Parl. Papers, China no. I (1899), p. 86.

4 Annual Register, 1898, p. 34I. 
Germany, Russia, France and England having obtained "leases" on the seaboard of China and thus strengthened their position in the Far East, the Taigai-doshi-Kwai, or Association on Foreign Policy, was formed in Japan, in April, 1898, by prominent statesmen of the different political parties, with a view to induce the government to take measures to meet the new order of things. When its representative called upon Marquis Ito on April 7, the premier " assured them that the government would not neglect to promote the interests of the nation," and is said to have intimated " that the attitude of Great Britain was very favorable " to Japan. ${ }^{1}$ And in April, 1898, the Japanese government, in order to forestall the lease or occupation of the province of Fokien opposite Formosa, by a European power, so as to menace Japan's possession of Formosa and the Pascadores Islands, demanded and obtained from China a promise not to alienate the province just as England had done in respect of the Yang-tsze valley. ${ }^{2}$

The last country to be considered with reference to the Far Eastern question, is Italy. On February 28, 1899, Sgr. Martino, the Italian minister, demanded of the Chinese government

the lease of Sammum Bay on the coast of Che-kiang as a coaling station and naval base, including the concession of three islands off the coast, with the right to construct a railway from Sammum Bay to Poyang Lake within a sphere of influence comprising the southern two-thirds of Che-kiang province. ${ }^{3}$

Great Britain apparently regarded the Italian co-operation

1 The Far East, 1898, vol. iii, pp. 333-334.

2 Annual Register, 1898, p. 340; China no. I (1899), p. I12. See also Rockhill's edition, p. I8I.

3 Annual Register, 1899, p. 358. 
as necessary to the preservation of the balance of power in the Far East, and the British minister supported the Italian demands; but the Tsung-li-Yamen would not listen to them; and the Italian government, limiting its activity to commercial matters, obtained a mining concession in northern Che-kiang in August. ${ }^{1}$

The weakness displayed by the Chinese government in the Japanese war, and in the subsequent concessions to European powers, was, by the patriotic party in South China and by the progressive Chinese in Peking, ascribed to the corruption of the governmental system and to the mandarins' ignorance of western ideas. Prince Chun, the emperor's personal adviser, had already called attention to the superiority of the military methods of the western peaples. Meanwhile, certain scholars, professing a renaissance of Confucianism, but imbued with enthusiasm for western civilization, had started at Canton and Shanghai an agitation for reform. Kang-Yu-Wei, ${ }^{2}$ a leader of the new school, had tendered, from time to time, since the German occupation of Kiao-Chau, petitions to the Emperor Kwang$\mathrm{Su}$ for the adoption of reform measures. The emperor, being rather a student of politics than a ruler, adopted the artificial measures of the new school and appointed KangYu-Wei to the important office of secretary of the board of works. By an edict issued on June I I, I898, all mandarins, central or local, from princes to " literati" (petty officials), were instructed to do their " utmost to discover which foreign country has the best system in any branch of learning;" and the establishment of a "metropolitan university" was

1 Annual Register, 1899, p. 358.

2 His article on "The Reform of China," in the Contemporary Review for August, 1899, shows the motive and attitude of the reform party. 
suggested as a necessary institution of the reform régime. ${ }^{1}$ Another edict was issued to replace the old system of apprintment of mandarins by the more modern competitive system. By an edict of June 12, a "special minister of commerce" was to be appointed, and a number of the imperial princes were to be sent abroad to investigate modern affairs and ideas. $^{2}$ Besides these, reformatory edicts regarding military organization, the judicial system and railways and mines were successively issued. The reform party naturally obtained the sympathy of the Japanese ard the English, who were very jealous of the predominant influence of Russia at Peking. The reformation went on. Weng-Tung-Ho, a member of the Privy Council, and $\mathrm{Li}$ Hung Chang, a leading member of Tsung-li-Yamên, both most conservative figures among the mandarins, were dismissed from office. ${ }^{3}$

The proceedings of the reformers were so radical that Marquis Ito, during his stay at Peking, sought to discourage Kang-Yu-Wei, the leader of the reform party, by intimating that they were attempting "to carry out in a week reforms which it had taken more than a quarter of a century to accomplish in Japan." ${ }^{4}$ It is no wonder that they brought about a reaction, which on September 2 I produced a coup d'état, since their radical measures not only violated Chinese prejudices, but also destroyed mandarinism, the fundamental fabric of the Manchu government. The empress dowager resumed her controlling power and all reform measures were suspended by an edict. The emperor became only the nominal ruler; the mandarins of the conservative party were restored to their offices; most of the

1 Parliamentary Papers, China no. I (1899), p. 179.

2 Ibid., p. 180.

3 Ibid., pp. 181 and 240.

4 Pierre Leroy-Beaulieu, The Awakening of the East, p. 278. 
reform party were beheaded or sent into exile, and its leader, Kang-Yu-Wei, secretly took refuge on board an English ship. ${ }^{1} \quad$ Thus the reform measures brought no cure to " the Sick Man of the Far East."

After obtaining leases of territory on the Chinese coast, the powers entered into a scramble for further concessions, relating to railway construction, the exploitation of mines, and the extension of the foreign settlements; but the contest as to railways was the most active. As Russia desired to obtain exclusive control of railway matters in Manchuria and Pechili, her chargé d'affaires, M. Pavloff, in March, I898, pressed the Yamên for the removal of Mr. Kinder, a British subject, from his position as superintendent of the Tientsin-Shan-hai-kwan Railway, and demanded that the "line north of Shan-hai-kwan should be constructed by Russian engineers and with Russian capital." 2 Had Russia been permitted to connect Peking and the Manchurian branch of her railway by the proposed line, she would have obtained direct control of Peking; New-Chwang, the only treaty port in North China, would have been doomed; and in the end the commerce of Japan, Great Britain and other powers would have been excluded from North China. Instead of awaiting the ruin of the British interests in that quarter, the Hong-Kong and Shanghai Bank entered into a preliminary agreement to furnish the capital to construct a railway between Peking and New-Chwang, taking a mortgage on the line. ${ }^{3}$ This caused much irritation in Russia, where the English concession was regarded as an invasion of the Russian sphere of interest.

1 Parliamentary Papers, China no. I (1899), pp. 256, 257, 258 and 265; For. Rel., 18g8, pp. 218-223.

2 Parliamentary Papers, China no. 2 (1899), p. I.

3 Ibid., pp. 2 and 4. 
On the other hand, Great Britain became involved in another contest over the trunk line between Peking and Hankow, projected by Belgium, backed by France and Russia. As such a highway would pass through the Yang-tze valley, the proposal was sure to provoke the opposition both of England and of China. Belgium, a " neutral country," was therefore introduced as the builder of the line, and a Belgian syndicate, termed La Société d'Etude des Chemins de fer en Chine, acting under the patronage of the Russian and French ministers at Peking, entered in May, I898, into negotiations with China for the construction of a trunk line between Peking and Hankow. ${ }^{1}$ This railway was to connect with the Manchurian line in the north and the French line in the south. England lost no time in endeavoring to check this scheme of Russia and France. She protested to China, Lord Salisbury declaring that "a concession of this nature is no longer a commercial or industrial enterprise and becomes a political movement against the British interests in the region of Yang-tsze." ${ }^{2}$ China, however, granted the concession to the Belgian syndicate, and England then demanded a corresponding concession. English and German syndicates obtained a concession to construct a line between Tientsin and Ching-kiang, near Nanking; the American-China Development Company, an American syndicate, secured a concession for a trunk line between Hankow and Canton, in which British capital is largely invested; and a trunk line from Canton to HongKong was to be constructed by the Jardine Syndicate, an English association. As an offset to the concession to the Russo-Chinese Bank in Honan and Shanse, Anglo-Italian capitalists, called the "Peking Syndicate," obtained a cor-

${ }^{1}$ China no. I (1899), pp. 96-97; London Times, May 23, 1898.

¿ China no. I (1899), p. II7. 
responding concession in the same provinces; while, as against the French concession for the Tonking railway, an English firm secured the right to extend the Indo-Burmese line to the head of the navigable waters of the Yang-tze. ${ }^{1}$

Amid these railway struggles and mutual encroachments, M. Lesser, the Russian chargé d'affaires in London, on August 12, proposed to Mr. Balfour that the spheres of interest of the powers should be definitely settled. ${ }^{2}$ After numerous diplomatic discussions, England and Russia, in April, I899, entered into a solemn agreement to respect each other's spheres of interest in Manchuria and in Yang-tze respectively, excepting as to the New-Chwang-Shan-hai-kwan line, which had already been mortgaged to the English. ${ }^{3}$ Although Germany and Great Britain co-operated in obtaining the concession for the Tientsin-Nanking railroad, their financiers agreed to respect their particular spheres, so that Germany is to guarantee the line in Shantung and England in the Yang-tse valley. ${ }^{4}$

In this way the powers have, from the political and economic points of view, established their so-called "spheres of interest," thus dividing up the Chinese Empire, and leaving it only in name a sovereign state. Such a condition of things necessarily suggests the possibility that the various powers may, by an extension of their acquired jurisdictional and administrative rights, seek to annul the treaty rela-

1 See "Summary of Railway Concessions," China no. I (1899), pp. 344-347; the texts of contracts of these railway concessions are found in Rockhill's edition. But as to the Canton-Hankow Railroad concession, the American-China Development Co., on Aug. 29, 1905, decided to sell the concession back to the Chinese government. The price to be paid is $\$ 6,750,000$. The New York Times, Aug. 30, 1905 .

2 China no. 2 (1899), p. 6.

I Ibid., p. 85.

- Annual Register, 1899, p. 360. 
tions of the mercantile nations with China by imposing discriminating taxes, duties and charges in the ports and rivers and on the railways in their respective spheres, and thus practically exclude their competitors from the Chinese market. Nevertheless, although the commercial interests of the United States in China are among the first in extent and importance, Uncle Sam, in 1898 , being occupied in the annexation of Hawaii and the war with Spain, exhibited little concern over the Far Eastern complications. But, after the war with Spain was over, the government eventually came to exert itself to protect its commercial interests, which were threatened by the "special concessions," the "preferential rights" and the "spheres of interest" of the European nations. Mr. Hay, as secretary of state, on September 8, I899, submitted a circular note to the powers for the purpose of securing a declaration in favor of equal commercial opportunities for all treaty nations. ${ }^{1}$ This circular sounded the keynote of the "open door" policy. It requested the powers to pledge themselves not to "interfere with any treaty port or any vested interests" within any so-called "sphere of interest" in China, and to engage that the customs tariff upon goods imported by any nationality into any port within any "sphere of interest" should be collected by the Chinese government, and that no higher harbor duties on vessels, and no higher railway charges on merchandise, belonging to any other nation should be levied than on those belonging to the nation which maintained such "sphere of interest." France, Germany, Great Britain, Italy and Japan gave the United States a satisfactory pledge of the formal recognition of the "open door" policy; but Russia's answer was less satisfactory, as she reserved the right to levy customs duties on foreign im-

1 For. Rel., 1899, pp. 128 et seq. 
ports in her sphere, and only promised not to make any discrimination between foreign nations. Furthermore, the Russian answer is silent upon harbor duties and railway charges. ${ }^{1}$

1 For. Rel., 1899, pp. 141 et seq. Count Mouravieff to Mr. Tower. 


\section{CHAPTER IX}

The Far Eastern Question, I900-I905

The Boxer Troubles of 1900.-European activities and enterprises within their "spheres of interest" in China, especially those of Germany in the Shantung province, aroused the anti-foreign or anti-Christian feelings of the Chinese in the spring of 1900 . A secret society, known as the Boxers, first appearing in the Shantung and Chili provinces, marched thence toward Tientsin and Peking with overwhelming force, destroying and burning churches, stations and railways. The Chinese government despatched troops to subdue the insurgents, but so strong were the rebels that the imperial forces were repelled. The foreign representatives in Peking, on May 28, 1900, felt obliged to summon marines from their respective fleets in order to meet a possible emergency. ${ }^{1}$ Prince Tuan, commander-inchief of the Chinese army, however, combined with the Boxers instead of suppressing them, when they approached the capital. On June 12, the Peking telegraph line was cut and the legations were besieged. From this time, the foreign representatives were absolutely isolated from the outside world. The "international relief expedition," 2000 strong, consisting of the marines of Great Britain, Germany, France, Austria, Japan, Italy, the United States and Russia, under the command of Admiral Seymour, was unable even to reach Tientsin. Meanwhile, Mr. Sukiyama, the chan-

1 Parl. Papers, China no. 3 (1900), p. 30. 
cellor of the Japanese legation, and Baron Von Ketteler, the German minister, were murdered, and some of the legations at Peking were burned or otherwise destroyed.

At this critical juncture, Lord Salisbury, as " considerable time [would] elapse before the relief from India or Europe could arrive," made an earnest appeal, on June 25, to the powers concerned in Chinese affairs to approve the immediate despatch of a Japanese force of 20,000 to 30,000 men. ${ }^{1}$ Japan agreed to send 13,000 men and mobilized 2,500 , in addition to those already despatched; but, fearing lest complications might arise among the powers themselves, she hesitated to do more. The British government became impatient and urged Japan to complete the expedition, Lord Salisbury declaring:

Japan is the only power which can act with any hope of success for the urgent purpose of saving the legations, and, if they delay, heavy responsibility must rest with them. We are prepared to furnish any financial assistance which is necessary, in addition to our forces already on the spot.

In spite of this strong exhortation, Japan held back. The United States approved the British proposal, in case Japan should send an expedition "with the assent of the other powers," ${ }^{2}$ but continental Europe, especially Germany and Russia, openly dissented. ${ }^{3}$ To give to Japan " a special mandate," Russia intimated, might " entitle that country to claim an independent solution of the difficulty and any other privilege," and " might, to a certain extent, encroach on the fundamental principle-the maintenance of the union between the powers; the maintenance of the existing system

1 Parl. Papers, China no. 3 (1900), p. 75.

2 China no. I (Igor), p. 3.

3 China no. 3 (1900), p. 92, and China no. I (1901), pp. 37-40. 
of government in China; the exclusion of anything which might lead to the partition of the empire; finally, the reestablishment by common effort of a legitimate central power, itself capable of assuring order and security to the country." 1 The English proposal involved nothing political, but was intended only to meet without delay a grave emergency. As between Japan and Russia, however, the urgent purpose of the proposal was subordinated to political jealousy. Owing to the Russian objection and the consequent Japanese hesitation, the relief expedition did not set out from Tientsin until August 6, when all the powers had joined their forces and agreed to act together. Had the legations succumbed to the Boxers before the relief forces reached Peking, Japan and Russia doubtless would have been blamed.

As the action of the powers, apart from the immediate object of saving their legations, was not governed by any definite understanding, there was danger that the opportunity might be seized by ambitious governments to carry out schemes for the partition of the Chinese empire. The United States, therefore, sent a circular note, on July 3, I900, to Berlin, London, Paris, Rome, St. Petersburg and other European courts, and to Tokyo, inviting the powers to adhere to the principles maintained by the United States on the Chinese question. ${ }^{2}$ Secretary Hay's former circular of September, I899, was designed to preserve equal privileges in China for all commercial nations. By the new circular, the United States not only re-affirmed the open-door policy but also strongly declared itself in favor of maintaining the integrity of the Chinese Empire. Great Britain announced

1 China no. I (I90r), pp. 12 and 25.

2 Report of Mr. Rockhill, Sen. Ex. Doc. 67, 57th Cong., Ist Sess., printed also as an Appendix to For. Rel., Igor, p. 12. 
a similar policy in the House of Commons on August 4, and communicated it to the powers. ${ }^{1}$

After numerous skirmishes and battles, the allied forces entered Peking; the legations were relieved on August I5; the emperor and the empress dowager fled to Taiyuan, the capital of Shanshi; the Boxers were scattered; the palaces and main buildings in Peking were occupied by the international forces. ${ }^{2}$ In the joint expedition the Japanese soldiers won marked distinction by their excellent behavior and ability. Lord Salisbury instructed the British minister at Tokyo to express to the government his earnest admiration of their "gallantry and efficiency," which had, as he declared, "contributed to the success of the expedition so very largely."

Li Hung Chang soon appealed to Great Britain, France, Germany, Japan and the United States for the cessation of hostilities, the immediate commencement of peace negotiations and the withdrawal of the foreign troops from Peking. ${ }^{3}$ Russia deferred action on the appeal, and submitted to the powers on August 28 a proposal for the evacuation of Peking by the allied troops and their legations, and their retirement to Tientsin, where peace negotiations should be opened. ${ }^{4}$ It was practically impossible to adopt this proposal, as the Boxers were still infesting the provinces adjacent to Peking, so that the evacuation of the city would tend to a renewal of hostilities, and would throw away the best opportunity to bring China to satisfactory terms. It is therefore not strange that most of the powers rejected the Russian proposal.

After the question of evacuating Peking was disposed

1 China no. I (Igor), p. 49.

2 China no. 3 (I901).

3 China no. I (I90I), pp. 99 and ror.

4 Ibid., pp. I1 3 and 122; For. Rel., 1900, p. 379. 
of, the German government, on September I8, sent a circular note to the governments of Great Britain, France, Austro-Hungary, Italy, Japan, Russia and the United States, proposing that China should surrender to the allies for punishment the chief instigators of the outrages and offenders against international law, who were to be designated by the foreign representatives, before entering on peace negotiations. ${ }^{1}$ The suggestion that punishment should be made a preliminary condition to negotiation provoked disagreement among the powers. The United States frankly declined the German proposal, pointing out that preliminary punitive measures would tend to endanger the negotiations. $^{2}$ As some of the ring-leaders were princes or royal personages, the Chinese court took alarm at the German proposal, and in an edict of September 25, published a list of offenders together with a statement of the accusations against them. ${ }^{3}$ Germany then proposed, on October 2 that the powers should instruct their representatives in Peking "to examine and give their opinion on the following points: (I) whether the lists of the names contained in the edicts are correct;" (2) "whether the punishments proposed [by China] meet the case;" (3) " in what way the powers can control the carrying out of the penalties proposed." 4

On October 4, 1900, the French government submitted to the powers a summary basis of peace negotiations, as follows : ${ }^{5}$

(I) Punishment of the principal culprits, to be designated by

1 China no. I (I901), p. I75.

2 Appendix to For. Rel. (1901), pp. 24-25.

3 China no. 5 (Igor), p. 6.
4 Ibid., p. 4.
Ibid., p. 5. 
the representatives of the powers at Peking; (2) maintenance of the prohibition of imports of arms; (3) equitable indemnities for states, societies and individuals; (4) establishment of a permanent legation guard at Peking; (5) dismantlement of the ports at Taku; military occupation of two or three points on the road from Tientsin to Taku

in order to keep the way open to the sea. The French proposal is said to have been suggested by Russia. ${ }^{1}$ However this may be, it was eventually approved by all the powers, and the draft of a joint note consisting of eleven articles was completed on November 24, the representatives of the powers waiting at Peking for the approval of their governments. $^{2}$ As to the punishment of the ring-leaders, the execution of eleven, including Prince Tuan and General Tang-fuh-siang, was demanded by the joint note, under the championship of Germany, whose policy was that of "severity and vengeance." Japan, on the other hand, did not agree to capital punishment, pointing out the impossibility of enforcing so severe a measure upon persons of royal rank who were still dominating the Chinese court at Singan-fu, its place of refuge. ${ }^{3}$ The United States particularly insisted on moderation, and intimated an intention to withdraw from the conference unless the stipulation as to capital punishment should be adjusted. Finally, the "death penalty" was replaced with the "severest punishment," under the leadership of the United States, supported by Japan, Russia and Great Britain." Although the draft

1 Dunnell's paper, "The Settlement with China," The Forum, vol. 32, p. 649 .

${ }^{2}$ China no. 5 (1901), pp. III et seq.

3 Ibid., p. 107.

4 Appendix to For. Rel., 1901, p. 54. The death penalty was insisted on by the German, Italian and Austro-Hungarian representatives. 
of the protocol provided for the sending to Berlin of an extraordinary mission to express the regret of the Chinese government for the murder of the German minister, it contained no clause of apology for the murder of the chancellor of the Japanese legation. The Japanese government therefore proposed to insert a stipulation for suitable reparation for that crime, and this was approved by the other powers. ${ }^{1}$ As regards the prohibition of imports of ammunition, the draft of the joint note used the words, "material necessary for the manufacture of arms and ammunition." As this clause might include materials which, though necessary for warlike objects, were still required for other purposes, and might thus prohibit the importation of things essential to trade and industry, Japan suggested that the words "material used exclusively for" be substituted for the words "material necessary for." ${ }^{2}$ After these several modifications, the joint note, embodying the irrevocable conditions of peace, was signed by eleven powers on December 22, I900. $^{3}$ The note demanded (I) that China should despatch envoys to Germany and to Japan to apologize for the murder of their diplomatic agents; (2) that the severest punishment should be inflicted on the persons designated in the imperial decree of September 25, I900; (3) that, to prevent the recurrence of anti-foreign movements, legation guards should be stationed at Peking, the importation of arms prohibited, the Taku forts dismantled, and the Tientsin-Peking route placed in military occupation; (4) that " an equitable indemnity" should be paid to the allies;

(5) that treaties should be negotiated, in order to improve

1 China no. 5 (1901), pp. 107, I18.

2 Ibid., pp. 107, 118, 120.

China no. 6 (1901), pp. 60 et seq.; Appendix to For. Rel., Ig0r, pp. 59 et seq. 
commercial facilities; (6) and that the procedure of the foreign office should be reformed. It may here be observed that by an imperial edict of July 24, I90I, the Tsung-li Yamên was transformed into the Wai-wa $P u$, or ministry of foreign affairs, which has precedence of the other six ministries of state.

The protocol, embodying the definitive terms of settlement, was not signed until September 7, I901. ${ }^{1}$ The conferences in the early part of I9OI were greatly hindered by the question of a "secret treaty" between Russia and China concerning Manchuria, which arrested the serious attention of the other powers, and by the question of indemnity. From the beginning the United States advocated a "lump sum," which should not exceed China's ability to pay. $^{2}$ A heavy indemnity would also necessitate an increase of tariff duties, which would operate as a hindrance to foreign importations. Commercial nations, like Great Britain and Japan, supported the moderate American plan, but they were out-voted by France, Germany, Russia and other continental powers. ${ }^{3}$ China finally agreed to pay an indemnity of $450,000,000$ taels, of which Russia was to receive I30 millions, Germany 90, France 70, Great Britain 50, Japan 34, the United States 32 , and so on. It is a striking fact that, although the claims of indemnity of each power were ostensibly based on actual cost and damage, those of the continental powers were comparatively greater in amount than were those of the powers specially identified with the open-door policy.

The Manchurian Question.-After the Boxer uprising, Russia mobilized a considerable number of soldiers on the

1 Appendix to For. Rel., I901, p. 312; China no. I (1902).

2 Appendix to For. Rel., I901, pp. 359, 361, 366, 369, 372, 373.

- See Dunnell, loc. cit. 
Mongolian frontier and in Manchuria under the pretense of railway protection; Newchwang, a treaty port, was captured on August 4, I900, and on the same evening the Russian flag was hoisted on the Chinese customs flag-post. ${ }^{1}$ The city of Mukden was occupied on October I ; and a military occupation was regularly instituted along the Russian railways in North China. In the meantime, Russia was supporting the wishes of the Chinese court, while the other powers were eagerly opposing the evacuation of Peking by the allied troops. Russian influence, which was dominant at Peking, and Russian activities in Manchuria, induced a rumor in Europe, as well as in Japan, of a possible Russian annexation of Manchuria and Mongolia. Russia, from time to time, issued an "official communiqué," or a semi-official note, to set at rest the rumor, by pretending that her occupation of Manchuria was of a purely "provisional and temporary nature." 2

Under the circumstances, England and Germany concluded, on October I5, I900, an agreement regarding Chinese affairs and embodied it in a circular to AustriaHungary, France, Italy, Japan, Russia and the United States for their acceptance. ${ }^{3}$ Its main object was to restrain any power which might be disposed to violate the principle of commercial equality in China or her territorial integrity. As the aim of the Anglo-German convention was identical with that of Mr. Hay's circulars of September, I899, and July, I900, the United States expressed full sympathy."

1 Parl. Papers, China no. I (I90I), p. I90. See the report of Mr. Fulford, the British consul at Newchwang.

- 2 Ibid., pp. 102, I13, I54.

3 For the text of agreement and diplomatic correspondence among the powers, see China no. 5 (1900).

4 Appendix to For. Rel., I90I, p. 31. Mr. Hay to Lord Pauncefote. 
All the other powers professed to assent to the principle of the agreement. Japan, being especially interested, inquired of Great Britain as to the status of adherents to the agreement. Being assured that they would be " in exactly the same position as if they had concluded with her Majesty's government a like agreement," Japan made a solemn declaration of adhesion. ${ }^{1}$

Notwithstanding the fact that Russia professed to accept the principles of the Anglo-German agreement, she was secretly preparing to conclude a separate treaty with China in regard to the occupation of Manchuria. The Peking correspondent of the London Times, Dr. Morrison reported, in the issue of January 3, I9OI, a "Manchurian convention," consisting of nine articles, concluded between delegates of Tsêng Chi, the Tartar general, and Admiral Alexieff, commander of the Russian Pacific squadron, under which, as he pointed out, Manchuria would be "a de facto Russian protectorate." The Times further suggested, in its editorial column, that the principle of the Anglo-German agreement should be applied to the alleged convention. The report alarmed the powers, especially Japan and England. The British government immediately instructed its representatives at St. Petersburg and Peking to ascertain whether the convention really existed. Sir Earnest Satow, English minister at Peking, replied that the Times' report was believed to be authentic; that the convention had been signed on the $22 \mathrm{~d}$ of the preceding November, and was then in Peking awaiting confirmation. ${ }^{2}$ Japan directly inquired of the Russian and Chinese governments as to the existence of the alleged convention, but both governments kept it a strict secret. On February I5,

${ }^{1}$ China no. 5 (1900).

${ }^{2}$ China no. 6 (190I), p. 3. 
Japan warned the Chinese government of the danger to which it exposed its territorial rights by entering into a separate agreement with one power, while it was negotiating for peace with all the powers collectively. ${ }^{1}$ The same warning was given by Great Britain, Germany and the United States. $^{2}$ Thus pressed, the Chinese finally allowed the viceroy of Hankow to communicate to Mr. Fraser, the British consul-general at that port, a summary of the convention. $^{3}$ The viceroy at the same time asked how far the British government would support China, if she refused to sign. The full text of the convention was obtained by Sir E. Satow on March 6. ${ }^{4}$ By its terms, Manchuria was to be restored to China, but Russia was to retain a body of troops in Manchuria, in addition to those designed for railway protection, until China should have fulfilled "the last four provisions" of the convention. In case of disturbance, the Russian soldiers were to afford every assistance to China (art. 3) ; China was to agree not to establish an army, nor to import munitions into Manchuria (art. 4). China was to dismiss those governors and high officials who were antagonistic to friendly relations with Russia; a police force was to be organized by China, but she was not to employ in it the subjects of any other power (art. 5); nor were the "subjects of any other power" to be employed " in training Chinese soldiers and sailors in North China" (art. 6). "China's autonomous rights in the city of ChinChou" were to be abrogated (art. 7). Mining and railway concessions or leases of land to other powers, in Manchuria, Mongolia and other domains of Ili, Kashgar, Yar-

$\checkmark{ }^{1}$ China no. 6 (I90I), p. 41.

2 Ibid., pp. 78, 107, 108.

Ibid., p. 90.

4 Ibid., p. 110. 
kand, except Newchwang, were forbidden, nor were the Chinese themselves to build railways without Russian consent (art. 8). Russia was to construct a railway from the Trans-Manchurian line in "the direction of Peking up to the Great Wall."

By an imperial edict dated February 28, I901, the Chinese government instructed its ministers at Berlin, London, Tokyo and Washington to ask the governments to which they were accredited to join in a mediation between Russia and China. ${ }^{1}$ Germany suggested, in reply, that China should "apply to the conference of [foreign] ministers at Peking in this matter." 2 Meanwhile, on March 20 Russia modified her demands, by striking out the provisions regarding the abrogation of China's autonomous rights in the city of Chin-Chou and the non-employment of subjects of other powers for purposes of military instruction in North China, and by limiting to Manchuria the prohibition to alienate railway and mining concessions to other powers, ${ }^{3}$ but threatened to break off the negotiation if the convention as thus amended was not signed by March 26. China, however, appealed on March 2 I to Great Britain, Japan and the United States to influence Russia to extend the time for negotiation, since even the amended agreement would " not only prove injurious to China, but to the other countries who have treaty rights in that region" (Manchuria)." The United States again admonished China and Russia not to enter into a " separate agreement with an individual power while negotiations were going on at Peking with the concert of the allied powers," while the British government de-

1 China no. 6 (1901), p. 93.

2 Ibid., p. 109.

${ }^{3}$ China no. 2 (1904), pp. 13, I4, 15.

4 China no. 6 (I90I), p. I37. 
clared that " no good purpose could be served by applying for an extension of time," but suggested that the draft be submitted to the conference of representatives at Peking, in which his Majesty's minister would be instructed to act in conjunction with his colleagues on the subject. ${ }^{1}$

Japan, on her part, saw that a crisis had come. Perceiving that the intentions of Russia in Manchuria menaced not only the integrity of China but also the independence of Korea, she decided to take whatever steps might be necessary to check the high-handed Muscovite policy. Ac-' cordingly, she at first asked the powers jointly to demand that the Anglo-German convention of 1900 should be applied to Manchuria; ${ }^{2}$ but, after learning that Germany, because of her desire to be on good terms with Russia in Europe, did not consider the convention to be applicable to Manchuria; ${ }^{3}$ that England, by reason of the Boer War, was unable to control an adequate force in case of emergency, and that the United States, owing to her traditional policy, would probably be unwilling to combine with one power against others, Japan made known her purpose to stand alone against the Russian policy in Manchuria. Hence, on March 25 the day before the date fixed by Russia for the signature, Japan made a direct friendly request to the St. Petersburg government that the Manchurian agreement be submitted to the conference of the powers at Peking for examination; ${ }^{4}$ at the same time, she was preparing for any possible emergency, a meeting of the commanders of the imperial army and navy being held in Tokyo. Russia

${ }^{1}$ China no. 6 (190r), pp. 139, 142 and 144.

2 Annual Register, 1901, p. 367.

${ }^{3}$ London Times, speeches by the Chancellor Count von Bülow, in the Reichstag, on March 15, 190 r.

4 Gaiko-Jiho, no. 39, p. 31. 
replied that, "in regard to the matter which is still in the course of negotiation between China and Russia, the latter is not inclined to discuss it with any third power." 1 The convention, however, was not signed on the 26 th, and Russia extended the time till April I. ${ }^{2}$ But, backed by the moral support of the powers, China again failed to sign, and Russia announced in the Messager Officiel of April 6, that the agreement had been temporarily withdrawn. ${ }^{3}$

The Anglo-Japanese Alliance.-Russia secretly resumed her negotiations concerning the occupation of Manchuria in August, I90I. Her new proposal was substantially identical with the amended draft of March 20; no date was fixed for evacuation. ${ }^{4}$ Her demands were still incompatible with the open-door policy and with Chinese sovereignty, but she does not appear at this time to have pressed China very hard, since the negotiations were without effect. After the conclusion, however, of the peace protocol between China and the allied powers, which was signed on September 7 , the Russian chargé d'affaires, M. Lessar, sought an opportunity to resume negotiations with Prince Ching. The Russian demands were now greatly modified, and the date of evacuation was definitely fixed at three years. ${ }^{5}$ Nevertheless, Great Britain and Japan urged China not to sign, while Mr. Hay instructed Mr. Conger, the American minister at Peking

to advise Prince Ching that the president trusts and expects

1 Gaiko-Jiho, no. 39, p. 32.

2 Ibid.

${ }^{3}$ China no. 6 (I90I), nos. 237 and 238, pp. 169, I70, et seq.

4 In Parl. Papers, China no. 2 (1904), pp. 25 et seq., three draftconventions are given: the original text reported by $\mathrm{Sir}$ E. Satow on March 6, the text as modified on March 20, and the proposal made in August.

s For. Rel., I902, p. 27 I. 
that no arrangement which will permanently impair the territorial integrity of China, or injure the legitimate interests of the United States, or impair the ability of China to meet her international obligations, will be made with any single power. ${ }^{1}$

Nor did Russia abandon her designs in south Korea, with the failure of her strategic measures at Masampho in 1900. M. Pavloff, the Russian minister at Seoul, in I9or, endeavored to obtain a lease of Ching-Kaiwan, an important bay in the extreme south, between Port Hamilton and Masampho, for naval purposes. ${ }^{2}$ As on the previous occasion, Japan objected, because "only Russia would have access" to the bay, and its possession by her would constitute a menace to the Japan Sea.

Under these circumstances, Great Britain and Japan, being constantly disturbed by the Russian movements in Manchuria, entered into an alliance, which was signed in London on January 30, 1902, by Lord Lansdowne for England, and by Baron Hayashi for Japan. ${ }^{3}$ Its fundamental aims are to maintain "the status quo and the general peace in the extreme East," to guarantee "the independence and territorial integrity of the Empire of China and Korea," and to secure "equal opportunities in those countries for the commerce and industry of all nations." More particularly were the British interests, which are principally in China, and the Japanese interests in China and in a peculiar degree in Korea politically as well as commercially, to be guaranteed. The provisions of the alliance are exceptional in that, should Japan or Great Britain go to war with a single power for the defence of the interests above stated, the other contracting power is required only to maintain "strict neutrality"

1 For. Rel., 1902, p. 271.

2 Hamilton, Korea, p. 200.

- Parl. Papers, Japan no. I (1902); For. Rel., 1902, pp. 513 et seq. 
and to exercise "its efforts to prevent other [third] powers from joining in hostilities against its ally," but if two or more powers should go to war with one of the contracting parties, then the "other high contracting party will come to its assistance." The contracting parties evidently felt able each to hold its own, singlehanded, against any other power, but deemed it best to provide for joint action against the possible coalition of Russia with France. The term of the treaty is comparatively short, being only five years. This is as it should be, for the diplomacy and foreign relations of a government are more dynamic than the national policy. "It would be unwise," observed Prince Bismarck upon the Triple Alliance, "to regard it as affording a permanently stable guarantee against all possible contingencies which in future may modify the political, material and moral conditions under which it was brought into being." " The AngloJapanese convention is obviously a defensive alliance. Lord Lansdowne declared that it was entered into "purely as a measure of precaution," and that it "in no way" threatened "the present position or legitimate interests of other powers." It may become an offensive alliance only " where attack is the best mode of providing for the defence." ${ }^{2}$ Evidently it is a connection which should not be abused, since "'the casus foederis of the defensive alliance does not apply". to an unjust war on the part of the power demanding the assistance of the coalition. ${ }^{8}$. The Anglo-Japanese alliance is nothing more than the formulation of those principles which the great powers have already declared or pledged themselves to observe in the Far East, such as the opendoor policy of the United States, Great Britain and Japan,

1 Memoirs of Prince Bismarck, chap. xxix, p. 284.

2 Wheaton, Elem. of Int. Law, part 3, chap. 2, par. 15.

Ibid. 
the "fundamental principles" of Russian policy as supported by France, and the Anglo-German agreement of 1900. It differs from those declarations only in providing a measure for their effective defense, in case they should in violation of assurances repeatedly given, be infringed.

In America, though there was no official expression by the government, the Anglo-Japanese treaty was hailed by the press and the people as a measure that would secure the open door without involving the United States in political complications with European powers. Nevertheless, Secretary Hay, on February 2, I902, reminded the powers that exclusive measures in developing Manchuria would be detrimental to the open-door policy and to Chinese sovereignty, and specially requested "the earnest consideration of the imperial governments of China and Russia in this matter." 1

Russia and France responded to the Anglo-Japanese agreement with a joint declaration, which was sent on March 16,1902 , to the signatories of the peace protocol of I90I. " In this declaration "the allied governments of Russia and France" expressed approval of the principle of the Anglo-Japanese treaty. The "two allied governments" reserved to themselves, however, "the right to consult" as to "the means to be adopted for securing those interests," in case " either the aggressive action of third powers, or the recurrence of disturbances in China, jeopardizing the integrity and free development of that power, might become a menace to their own interests."

1 Memorandum on the grave conditions existing in Manchuria, addressed to the signatories of the peace protocol of 1901, For. Rel., 1902, p. 275 .

2 Parl. Papers, China no. 2 (1904), p. 35 ; For. Rel., 1902, p. 931 ; London Times, March 19, 1902. 
The Russo-Japanese Difference. - Influenced by the Anglo-Japanese alliance and by the American representation of February 2, Russia further modified her demands in respect of Manchuria, and on April 8, 1902, concluded an agreement with China in the following terms: ${ }^{1}$ (I) Manchuria was to be restored to the Chinese government; (2) but, in resuming the administration, China was to " observe strictly the stipulations of the contract concluded with the Russo-Chinese Bank on the 27th of August, I896;" (3) the Russian troops were to be withdrawn from "the southwestern portion of the Province of Mukden up to the River Liao-Che" within six months, from "the remainder of the Province of Mukden and Province of Kirin" within a further six months, and from "the province of HeihungChiang" within yet another six months; (4) the military and police administration in Manchuria was to be restored to the Chinese government without heavy restrictions; (5) Russia was "to restore to the owners the Railway Shanhai-kwan-Newchwang-Sinminting," which had been held by Russian troops since the end of September, 1900. As the railway is mortgaged to the Hongkong-Shanghai Bank (an English institution), Russia, in consideration of restoring the line, required China (I) not to "invite other powers to participate in its protection, construction, or working, nor allow other powers to occupy the territory evacuated by Russia," in case protection of the line should be necessary; (2) strictly to observe the agreement as to the Anglo-Russian sphere concluded in April, I899, and not to allow the bank "to enter into possession of or in any way to administer" the line; (3) to consult Russia as to the extension of the line, the construction of the branch line,

1 Parl. Papers, China no. 2 (1904), pp. 36 et seq.; For. Rel., 1902, pp. 280 et seq. 
the erection of a bridge on the Liao River at Newchwang, and the moving of the terminus thither; (4) to pay Russia all expenses of the "repair and working" of the line incurred during the occupation. Russia promised China, by a separate note, ${ }^{1}$ to restore the civil government of Newchwang as soon as the "international administration at Tientsin " was surrendered to Chinese authority. The Russian demands concerning Manchuria were thus made less exclusive than before, and the period of three years for evacuation was reduced to eighteen months. The ministers of Great Britain, Japan and the United States, at Peking, therefore notified Prince Ching of their assent to the signing of the agreement. ${ }^{2}$

Russia faithfully observed the first term of the evacuation; by October 8 the withdrawal of the Russian troops from the region between the Great Wall and the Liao River was complete. But, when the second term expired on April 8, 1903, no actual evacuation had taken place in the designated places, except the city of Mukden. Not only did the evacuation of Newchwang remain to be carried out, but in April Russia seized the customs and the municipal administration of the treaty ports, and in the beginning of May occupied the forts at the mouth of the Liao River. ${ }^{3}$ Moreover, M. de Plançon, the Russian chargé d'affaires at Peking, had, on April I8, submitted to Prince Ching a series of new demands as to the conditions of evacuation. They ran as follows : ${ }^{4}$

I. No restored territory, particularly in Newchwang and on the Liao River, was to be transferred to any other power, " whether by way of cession, lease, concession, or in any

1 Chixa no. 2 (1904), p. 38.

2 For. Rel., 1902, p. 277.

- China no. 2 (1904), p. 63.

- For. Rel., 1903, pp. 57 et seq. 
other form." Any such transfer to another power, Russia would regard as "a threat" to her interests.

II. The existing system of Russian administration, as during the occupation, was to be preserved in Mongolia.

III. Without consulting Russia, no port was to be opened to foreign trade, nor were consuls of the powers to be permitted to reside in Manchuria.

IV. No foreign adviser engaged by China was to interfere in any branch of administration in northern China, "where Russian interest predominates."

V. Russia was to control the entire telegraph line in north China.

VI. "After the transfer of Newchwang to Chinese administration," the Russo-Chinese Bank was to continue " to fulfill the function of the customs bank."

VII. All rights acquired in Manchuria by Russian subjects or established during the occupation" were to "remain in full force after the departure of the troops." Russia further demanded the control of the sanitary administration at Newchwang.

These Russian demands soon came to the knowledge of Great Britain, Japan and the United States, who lost no time in seeking to counteract them. Especially could they not keep silence as to the Russian measures at Newchwang, where "the trade is almost exclusively British, American and Japanese." The British government particularly called the serious attention of the Chinese and Russian governments to the exclusive demands of Russia as violating the most-favored-nation clause in the Tientsin treaty of 1858. ${ }^{1}$ In negotiating new commercial treaties with China, Japan and the United States demanded that certain ports

${ }^{1}$ China no. 2 (1904), pp. 55, 58. 
be opened and consulates established in Manchuria for the benefit of foreign trade, but the Chinese government each time declined to discuss the subject, owing to Russian objections. Nor would China agree to open Mukden and Tatung-kou until Secretary Hay had obtained, on July I4, the assent of the Russian government after several conferences with Count Cassini at Washington. ${ }^{2}$

Japan regarded the conditions demanded by Russia as not only destructive of the equal opportunities of the commercial nations, but as an infringement on Chinese sovereignty. The Japanese were further provoked by the movements of Russian troops in Manchuria and Korea. The troops evacuated Mukden, but concentrated at Liao Yang and occupied Feng Hang Ching and, later, Antung, on the Korean frontier, opposite $\mathrm{Wuji}$, on the Yalu river. While Russia often objected to the opening of Wuji, she established a settlement at Yungampo, and, on the pretext of protecting her timber concession, sent her troops across the Yalu into Korea. These aggressive acts produced a strong war feeling in Japan; even the conservative papers Jiji and Asahi often calling for the decisive settlement of the Manchurian and Korean questions. A memorial on the Far Eastern question, by seven professors of the law school of the Imperial University at Tokyo, was submitted for serious consideration to Count Katsura, the prime minister. ${ }^{2}$ It substantially suggested a resort to arms, if necessary to

1 For. Rel., 1903, pp. 5I et seq., and 9I et seq. The United States originally demanded the opening of Ta-tung-kou, Mukden and Harbin. As the result of the Hay-Cassini conferences, Harbin was waived for future negotiation, and Ta-tung-kou was replaced by Antung in the treaty signed October 8, 1903. Japan also succeeded in getting her treaty signed on the same day on which Mukden and Ta-tung-kou were opened to foreign trade. The text of these treaties is given in Rockhill's edition, pp. I2I-I70.

2 The text of the petition is given in the Taiyo. 
defeat the Russian movement. General Kuropatkin, then Russian minister of war, came to Japan in the summer of I 903 in order to cultivate a more friendly feeling. He was politely and cordially welcomed by the emperor and his people, but his visit could effect no change in the Japanese attitude, so long as the Russian movement in Manchuria and Korea was not modified. Japan maintained that this movement not only was a constant menace to the tranquillity of the Orient, but would result in the Russian absorption of Manchuria and Korea, whereby the interests of Japan in that important quarter would be destroyed and her power of self-preservation vitally endangered. The Japanese government therefore calmly, but seriously, took up the question at issue. The Gosen-Kaigi ${ }^{1}$ met on June 26 , in order to formulate a definite policy.

It was decided to open direct negotiations with the Russian government in order to secure a friendly adjustment of all conflicting questions pending between the two countries in the Far East; and Mr. Kurina, the Japanese minister at St. Petersburg, was instructed, on June 27, to make known the wishes of his government. As Russia expressed her willingness to enter into negotiations, the basis of a settlement was, on August I2, submitted by Japan, as follows : ${ }^{2}$

I. A " mutual engagement to respect the independence and territorial integrity of the Chinese and Korean empires, and to maintain the principle of equal opportunity of commerce and industry of all nations in those countries."

1 An imperial council composed of the cabinet members, and of the "Genros," or elder statesmen, and held before the throne.

2 The diplomatic correspondence between Japan and Russia prior to the late war was laid before the imperial Diet by Baron Komura, minister of foreign affairs, on March 25, 1904. An English text is given in The Japan Weekly Mail, March 26, 1904; the Japanese text, in the Kwampo (Official Gazette) of March 24 and 27. 
II. The " reciprocal recognition of Japan's preponderating interest in Korea and of Russia's special interest in railway enterprises in Manchuria," and the mutual recognition of the right of Japan and Russia, respectively, to take measures for the protection of the above mentioned interests so far as such measures do not violate the principles enunciated in the first provision, such as the open-door policy and the territorial integrity of the countries in question.

III. A reciprocal pledge " not to impede the development of those industrial and commercial activities respectively of Japan in Korea, and of Russia in Manchuria, which are not inconsistent with the stipulations" of the first provision; and an "additional engagement on the part of Russia not to impede the eventual extension of the Korean railway into southern Manchuria so as to connect with the East China and Shan-hai-kwan-Newchwang lines."

IV. A reciprocal engagement to send troops to the actual number required, by Japan to Korea, or by Russia to Manchuria, in case their respective interests were menaced or insurrection threatened to create international complications, and to withdraw the troops "as soon as their mission is accomplished."

V. The " recognition on the part of Russia of the exclusive right of Japan to give advice and assistance in the interest of reform and good government in Korea, including necessary military assistance."

VI. This agreement was to supplant "all previous arrangements between Japan and Russia respecting Korea," by which Russia had the right to give advice upon Korean affairs.

It was Japan's original idea to make St. Petersburg the seat of the negotiations in the hope that they might be 
carried on as quickly and satisfactorily as possible. ${ }^{1}$ On August I3, however, the day after the Japanese proposal was handed to Count Lamsdorff, the Russian minister of foreign affairs, the czar, "in view of the complex problems of administration on the eastern confines of the empire," issued an imperial ukase, ${ }^{2}$ by which he erected the "territories of the Amur and of Kwantung " into a special viceroyalty and appointed Admiral Alexieff as viceroy, investing him with supreme power in civil and military administration, and with the control of the diplomatic relations of the designated territories with " neighbouring states." The viceroy was "released from the jurisdiction of the ministries," but was made subject to "le comité special de l'Extrême-Orient," ${ }^{3}$ nominated by the czar and presided over by himself. As to the seat of the negotiations, Count Lamsdorff asked that it be transferred to Tokyo, which he regarded as more convenient, for the reason that there were " many details" concerning which it was necessary to consult Viceroy Alexieff at Port Arthur, and that the czar was to be absent from St. Petersburg for some time. Over this question some days were spent, when Japan, being unwilling to waste more time upon it, agreed to Count Lamsdorff's request.

The negotiations were transferred to Tokyo, but Russia's reply to Japan's proposal was not made until October 3 . It embraced: (I) a " mutual engagement to respect the independence and territorial integrity" of Korea; (2) the " recognition by Russia of Japan's preponderating interests" in Korea and of her right to advise the civil administration therein without infringing the first provision; (3) a Russian

1 Baron Komura's speech before the Diet, March 25, 1904.

2 Parl. Papers, China no. 2 (1904), p. 85.

3 Ibid., p. 92. By a ukase of September 30, the organization and jurisdiction of this special committee of the Far East were defined. 
pledge not to interfere with economic undertakings of Japan in Korea, " nor to oppose any measure taken for the purpose" of protecting such undertakings; (4) the recognition of Japan's right to send troops to Korea for the purpose of protecting her interests with the knowledge of Russia; (5) a mutual engagement not to use any part of the Korean territory "for strategical purposes nor to undertake on the Korean coast any military works capable of menacing the freedom of navigation in the straits of Korea;" (6) a mutual engagement to establish a neutral zone on the Korean territory, "lying to the north of the 39 th parallel;" (7) the recognition by Japan of Manchuria and its littoral as being "in all respects outside her sphere of interest." 1 Russia thus definitely refused either to enter into any engagement for the preservation of the territorial integrity of China, or to commit herself to the maintenance of the principle of equal opportunity for all nations in commercial matters. Furthermore, by requiring Japan to recognize Manchuria as being entirely outside her sphere of influence, and by striking out the Japanese proposal concerning the connection of the Korean railway with Newchwang through Manchuria, Russia virtually refused to make any engagement concerning Manchuria. On the other hand, she proposed to forbid Japan to send troops to Korea without the "knowledge of Russia," or " to use any part of Korea for strategic purposes," or " to undertake" fortifications on the Korean straits; and struck out the provision permitting Japan to render "military assistance" to Korea.

Japan desired certain military facilities in Korea in order to safeguard Korean independence from foreign attack, to preserve the internal order of the country, and to protect her own interests there. Russia, on the other hand, pursuing

${ }^{1}$ Dip Cor. between Japan and Russia, no. 17. 
her own strategical objects, wished to restrict Japanese military measures, and to secure the defence of Manchuria against foreign invasion by establishing a neutral zone at the cost of Korea, as well as to assure, by forbiding fortifications on the Korean strait, undisturbed communication between her two great naval ports, Port Arthur and Vladivostok. Although Japan might have accepted, to a certain extent, the Russian proposal as to Korea, she could not abandon in silence the question of Manchuria, where she had vast commercial interests, as well as political interests, essentially connected with her position in Korea. In conferences with Baron Rosen, the Russian minister at Tokyo, Viscount Komura, then minister of foreign affairs, therefore demanded that Russia should agree to respect the territorial integrity of China, and proposed, as to the neutral zone, that, if one should be created it should be established on both sides of the boundary between Korea and Manchuria, with a width on either side of, say, fifty kilometers. ${ }^{1}$ This amended proposal was sent to St. Petersburg on October 30, and Japan requested an early response. The Russian answer was not received till December $\mathrm{II}^{2}{ }^{2}$ It entirely rejected the Japanese amendments, and, apart from consenting to "the connection of the Korean and East China Railway," struck out all clauses relating to Manchuria and reaffirmed the original Russian counter-proposal. As the absolute exclusion of the Manchurian question was incompatible with the professed object of the negotiation, Japan, in a note of December $2 \mathrm{I}$, requested Russia to reconsider her position, and proposed the entire suppression of the neutral zone, in case Russia should be unwilling to admit one

1 Dip. Cor. between Japan and' Russia, nos. 19, 22.

2 Ibid., no. 34 . 
in Manchuria. ${ }^{1}$ Japan, besides, offered to make substantial concessions in Korea-to limit her right of advice to matters of civil administration, to strike out the words " military assistance," and to admit a mutual engagement not to undertake on the Korean coast any military work capable of menacing the freedom of navigation of the straits of Korea. In her reply, which was made on January 6, 1904, Russia modified her previous proposals by offering to recognize the rights and privilege of the treaty powers in Manchuria, on condition that the neutral zone should be established in northern Korea only, and that Japan should not use any Korean territory for strategic purposes; but she still refused to agree to respect the territorial integrity of the Chinese Empire. ${ }^{2}$ A few days later, on January I3, Japan submitted another note, in which she insisted on the entire abolition of the neutral zone, as well as on the integrity of the Chinese territory, without which the treaty rights of other powers in Manchuria could not be secure, and, while proposing these important amendments " in a spirit of conciliation" requested Russia to receive them in the same spirit. ${ }^{3}$ To this conciliatory request Russia did not reply. Mr. Kurino repeatedly requested an answer, pointing out that "further prolongation" would be to the "serious disadvantage of the two governments," but, in an interview as late as February I, Count Lamsdorff still failed to say when the Russian reply might be expected.

Meanwhile the Russian troops were massing on the Korean frontier along the Yalu River, and the formidable squadron of Admiral Wirenius, in the Mediterranean Sea,

1 Dip. Cor. between Japan and Russia, no. 35.

2 Ibid., no. 38.

3 Ibid., no. 39 . 
was proceeding to the Far East. On February I the Japanese commercial agent at Vladivostok was formally notified that the port might be put in a state of siege, and was requested to prepare for the withdrawal of the Japanese residents. Japan, interpreting these actions to mean that the Rusian government had no faith in an amicable settlement and intended to dictate its own terms by force if necessary, came to the conclusion that further delay would be dangerous to her interests. A Gosen-Kaigi was held on February 3 , and the Japanese government, on February 5, addressed to Russia a note terminating the pending "futile negotiations," and reserving " the right to take such independent action as they may deem best to consolidate and defend their menaced position, as well as to protect their established rights and legitimate interests." ${ }^{1}$ At the same time Mr. Kurino was instructed to withdraw, with his staff and students, from St. Petersburg. Diplomatic relations were thus severed, but hostilities did not take place until the torpedo squadron of Admiral Togo attacked the Russian fleet in the mouth of Port Arthur harbor on February 9. Declarations of war were formally made, respectively, by Russia on the $9^{\text {th }}$ and by Japan on the following day. ${ }^{2}$

The Anglo-Japanese alliance operates more effectively than ever. It was concluded mainly as a guarantee of peace. "Should peace unfortunately be broken," declared Lord Lansdowne, at the time when the treaty was made, "it [the alliance] will have the effect of restricting the area of hostilities," ${ }^{3}$ since England would use her efforts to prevent France from combining with her ally, Russia. If France should become entangled in the Russo-Japanese war,

1 Dip. Cor. between Japan and Russia, no. 48.

2 London Times, Feb. II and 12, 1904.

s Parl. Papers, Japan no. I (Ig02). 
England would come to the aid of Japan, and this might induce a universal conflict, spreading at least throughout the eastern hemisphere. In the course of an expedition to the Far East by the "Baltic fleet," or the "second Pacific fleet," under Vice-Admiral Rojestvensky, their prolonged stay at Madagascar, a French colony, in the winter of 1904-5 constituted a grievance of the Japanese against France because of her indulgent attitude as a neutral. The Japanese government, however, paid little attention to it, the distance from Madagascar to the seat of war being great, and the benevolent assistance of France hardly affecting the hostile operations. But the long continuance of the Baltic fleet at Kamranh Bay and Hon-kohe harbor of French Indo-China in the spring of I905 excited the indignation of the Japanese press, which characterized the French attitude as belligerent rather than neutral, and declared that it constituted "the casus foederis" of the Anglo-Japanese alliance. The formal representations to the French government by Dr. Motono, the Japanese minister at Paris, the prompt answer by the French minister of foreign affairs, M. Delcassé, and the enforcement of the neutral rule at Indo-China by the French admiral, De Jonquières, eventually averted the possible entanglement. ${ }^{1}$ It was highly desirable that the immediate parties to the war should be left to themselves, without any interference from allies or third powers, just as in the case of the Austro-Prussian and Franco-Prussian wars. On the other hand, mediation, in order to terminate the war in a manner honorable to both parties, at the earliest possible moment, was equally desirable.

So far as the campaigns of the belligerents were con-

${ }^{1}$ London Times, April 21 and May 4, 6, 8, 9, 10, 11, 12, 13 and 18, 1905 . 
cerned, Japan, for about a year and a half after the outbreak of hostilities, maintained an unbroken series of victories on land and sea. The strong fortress of Port Arthur, " the Gibraltar of the Far East," fell into Japanese hands and the "first Pacific fleet" in the harbor was destroyed. The great battle of Mukden, which Russia hoped might be the turning-point of the war, brought nothing but fresh disaster to the czar's army in Manchuria. The "invincible armada" of Admiral Rojestvensky, combined with the "third Pacific fleet" of Admiral Nebogatoff, which promised to recover the czar's maritime prestige in the Pacific, was utterly annihilated by Admiral Togo, "the Nelson of Japan," on the Sea of Japan. The land communications of Vladivostok were at the mercy of Field Marshal Oyama and its harbor was indirectly blockaded by the Japanese fleets at the northern straits of Japan and the Korean straits. Furthermore, the war policy of the autocratic government was threatened from time to time by internal dissensions. The successive defeats of Russia made it more difficult for her to raise war loans in foreign markets. On the contrary, Japan did not, in a year and a half's experience in carrying on hostilities on a gigantic scale, receive any check, financial or military.

The Peace of Portsmouth.-As the result of the exercise of President Roosevelt's offices, the belligerents appointed peace commissioners to meet at Washington. ${ }^{1}$ Baron Jutara Komura, minister of foreign affairs, and Mr. Kogoro Takahira, Japanese minister to the United States, were designated to represent Japan, while M. Sergius Witte, president of the imperial council, and Baron Romanovitch

1 On June 7, 1905, President Roosevelt addressed an identical message to the Japanese and Russian governments, suggesting the termination of the war. Both belligerents accepted his overtures. 
Rosen, Russian ambassador to the United States, were designated to represent Russia. These plenipotentiaries held their first meeting on August 9, 1905, at the navy yard at Portsmouth, New Hampshire, to which place the seat of the conference was transferred in order to avoid the summer heat of Washington. At the next meeting the plenipotentiaries exchanged their full powers, which were found to be in due form, and Baron Komura then presented in writing the Japanese demands. ${ }^{1}$ Although the victories of Japan might have justified her in assuming to dictate terms of peace, the Mikado and his advisers generously considered the interests of other powers which are concerned in the Far Eastern question, especially with regard to the open-door policy, by proposing that China's sovereignty and civil administration should be effectively restored in Manchuria, while order and progress in Korea were to be assured under Japanese protection. Bearing in mind also the dignity of Russia as a great power, Japan asked for "reimbursement" for the cost of the war, instead of " indemnity," which might have seemed to convey a more exacting or punitive meaning. The new conditions which had arisen since the rupture of negotiations with Russia in February, 1904, were, however, to a certain extent necessarily reflected in the Japanese demands for the cession of Sakhalin Island, ${ }^{2}$ the surrender to Japan of the Russian lease of the Kwantung peninsula, including Port Arthur, Dalny and Elliot Island, the transfer to Japan of the Chinese Eastern Railway below Harbin to Port Arthur,

1 An apparent synopsis of these demands may be found in the New York Times of Aug. 19, 1905.

${ }^{2}$ Gen. Liapnoff, the governor of Sakhalin Island, formally surrendered on July 31 to the commander of the Japanese army; and the whole island was immediately proclaimed to be under the Japanese administration. 
the surrender to Japan of the Russian warships interned in neutral ports, and the concession to Japanese subjects of fishing rights on the Russian littoral from Vladivostok north to Bering Sea. The strong desire of Japan for the "permanent peace of the Far East" also prompted a demand for certain restrictions upon Russian activity in Asia, by limiting the naval strength of Russia in the Pacific. M. Witte, on the morning of August 12, presented the counterstatement of Russia, and it was agreed to discuss the Japanese demands clause by clause. This discussion continued from day to day till August I8.

Eight clauses were, after some modification, agreed on, but as to the four remaining clauses, relating to Sakhalin Island, the interned warships, the limitation of Russian naval power, and the payment of an indemnity, there was an absolute disagreement. At this critical juncture, when the public had become exceedingly pessimistic as to the outlook, President Roosevelt is said to have had interviews with Baron Kaneko, "unofficial agent of the Mikado," and Baron Rosen, on the I8th and Igth of August, respectively, with a view to avert a failure of the conference. Meanwhile the cables to Tokio and St. Petersburg were kept busy to learn the imperial wills. At the conference on August 23, Baron Komura announced that Japan would relinquish her demands as to the interned warships and the limitation of naval force, and offered to restore a half of Sakhalin Island to Russia, on condition that she would pay to Japan I,200,000,000 yen, not as "indemnity," nor yet as "reimbursement," for the cost of the war, but as the price of the territory to be restored. ${ }^{1}$ This offer was peremptorily rejected by $\mathrm{M}$. Witte, and the conference adjourned until August 26. President Roosevelt is said again

1 New York Times, Aug. 24, 1905. 
to have exerted himself to prevent a deadlock by instructing Mr. Meyer, the American ambassador at St. Petersburg, to obtain an audience with the czar and urge, if possible, some concession on the part of Russia. At the conference on Saturday, August 26, the Russian plenipotentiaries appear to have submitted a proposition in the nature of an imperial ultimatum to pay Japan $100,000,000$ rubles on account of her expenses in caring for Russian prisoners of war and to cede half of Sakhalin Island. ${ }^{1}$ This proposition was of course not acceptable, but so conciliatory were the Japanese plenipotentiaries that they suggested the holding of another conference, at which they might submit modified terms, in order to satisfy Russian sensibilities, while preserving the principle of the Japanese demands. President Roosevelt is said to have made, on August 28, " a new appeal to the emperor of Japan on behalf of peace." On the same day the Gosen-Kaigi (council before the throne, consisting of the elder statesmen and the members of the cabinet) was held, in which the question of peace or war was discussed. By the supreme order of his government, Baron Komura, who is said to have insisted to the last upon reimbursement for the cost of the war, finally waived, on August 29, the three demands for reimbursement, the surrender of the interned warships, and the limitation of Russian naval force, and offered to restore to Russia the northern half of Sakhalin Island without any compensation. " "Your modified terms of peace," exclaimed M. Witte, "are accepted." The negotiation at Portsmouth was thus concluded in the brief term of twenty days. ${ }^{2}$

Japan's sacrifice, for the sake of peace, of her claim for reimbursement for the cost of the war, amounting to more

1 New York Times, Aug. 27, 1905.

2 For the text of the treaty of Portsmouth, see Appendix A. 
than $\$ 600,000,000$, called forth the applause of neutral nations, and even the Russians praised her "magnanimity in diplomacy" and her "moral victory," calling it as "worthy as her heroic victory in the war." For the most part, on the contrary, the Japanese press denounced the treaty, declaring that "the fruits of victory were again nullified by weak diplomacy, and by ill-counsels of the cabinet ministers and the elder statesman who give advice to the emperor." A sudden popular commotion took place at Tokyo, which was placed under martial law. At Kobe the recently erected statue of Marquis Ito, one of the elder statesmen, was thrown down and dragged through the streets. But the fact should be borne in mind that, although Japan was victorious both on land and on sea, her military position was very different from that which she held ten years before in the war with China, when her ability and readiness to make a direct assault on Peking caused the sending of $\mathrm{Li}$ Hung Chang to Shimonoseki, or from that held by Germany when Prince Bismarck dictated terms at the gates of Paris, surrounded by the German army. It has been well observed that, as the distance from European Russia to Manchuria has been of great benefit to Japan in the matter of war, so it has been of great advantage to Russia in the matter of indemnity. But as Japan waived three important demands, why, it may be asked, did she not then insist upon the retention of the whole of Sakhalin Island, which was proclaimed to be under Japanese administration? Besides, the occupation by Japan and Russia of different parts of the island is likely to be a source of complications, just as it was prior to 1875 . Nevertheless, it may be ungracious to criticize the "magnanimous concessions" of Japan until we are familiar with all the conditions that went to make up the "psychological moment" at which Japan yielded to the Russian ultimatum. After all, Japan gained by the treaty 
of peace more than she demanded prior to the war, while Russia not only abandoned to a great extent her material interests in Manchuria, but also lost much of her prestige in Asia by relinquishing Port Arthur, the Gibraltar of the East, and the branch line of her Manchurian railway. It is not improbable, however, that Russia's retention of the Trans-Manchurian line and of Vladivostok, which though icebound for half the year proved during the war to be a valuable arsenal, and her potential re-establishment of her Pacific squadron will powerfully contribute to preserve her prestige in the extreme Orient. It is certain that Russia has not been "wiped out," and that she will still weigh in the balance of power in the Far East as much as any eastern power or as any of the powers of the West. M. Witte ably reported the result of the peace negotiations to his imperial master thus: "Russia will remain in the Far East the great power which she hitherto has been and will be forever." In spite of the successive defeats of the czar's army and navy, his plenipotentiaries preserved the "dignity and honor" of Russia by their able manœuvering in diplomacy.

Finally, the fact should be emphasized that, while the "strenuous" but impartial efforts of President Roosevelt were from time to time exerted to avert the deadlock which often threatened to break up the negotiations, the conciliatory and magnanimous attitude of Japan was the vital and dominant influence that brought about the peace of Portsmouth.

The Status of Manchuria and Korca.-During the war the status of Manchuria and Korea, whose territories formed the theatre of the war, was somewhat complicated. Had China and Korea not been made the scene of hostilities their entire territories would, at least theoretically, have been neutral. Although Russia held a lease of the 
Kwantung district, including Port Arthur and Dalny, and although she possessed railways in Manchuria, the titular sovereignty and legal ownership belong to the Chinese government. ${ }^{1}$ Nevertheless, so long as Russia's military forces occupied Manchuria, she assumed the rôle of de facto sovereignty and was liable to attack there by her foe. ${ }^{2}$ Immediately on the breaking out of the war Japan, on February 9, 1904, called the attention of the several neutral powers to the desirability of preserving China's neutrality, in order to restrict hostile operations in that country. She pointed out that China, if she should become entangled in the war, would be unable to make the stipulated payments on the indemnity; that her foreign trade would be hampered; and that anti-foreign movements might again arise as in $1900 .{ }^{3}$ On the following day Secretary Hay, following a suggestion from Germany, addressed a note to the governments of Russia, Japan and China, in which he asked that Japan and Russia should respect "the neutrality of China" and " her administrative entity," and that " the area of hostilities shall be localized" as far as possible, so as to prevent uprisings of the Chinese people and the undue disturbance of foreign trade." At the same time a copy of the note was transmitted to " all the powers signatory to the protocol of Peking, requesting each of them to make similar representations to Russia and Japan." On February I3, China formally announced her neutrality, but observed that "in

1 Art. I of the convention, regarding the lease of Port Arthur, expressly reserves China's sovereignty over the leased territorics.

2 As to the position of Manchuria, see Lawrence, War and Neutrality in the Far East, pp. 219 et seq. Manchuria furnishes an analogy to what Hall terms "places under double or ambiguous sovereignty." Hall, Int. Law, 4th ed., pp. 530, 532.

3 The Kwampo (Official Gazette), Feb. 19, 1904, p. 387.

- MSS. Dept. of State; also New York Times, Feb. 10, 1904. 
Manchuria, however, there are localities still in occupation by foreign powers where the enforcement of such rules of neutrality, it is feared, will be impossible." 1 Japan, on February I 3 and 17 gave assurances to the United States and China, respectively, that she would " respect the neutrality of China so long as it is respected by Russia," excepting the region occupied by Russia. ${ }^{2}$ On February 19 Russia accepted the American proposal, subject to the reservation that "neutralization in no case can be extended to Manchuria, the territory of which, by the force of events, will serve as the field of military operations." 3 Even within Manchuria, Japan further limited the war-zone to the territories actually occupied by Russia, i. e., to the territory east of the Liao river. On the other hand, she engaged to respect the Chinese neutrality only so far as Russia respected it. The case of the "Ryeshitelni," a Russian torpedo-boat destroyer, which took refuge at Chefu, conipelled Japan temporarily to regard that harbor as belligerent." After the fall of Port Arthur, Russia, early in January, 1905, revived the question of the Chinese neutrality. Count Cassini, the Russian ambassador at Washington, made a representation to the department of state against the violation of Chinese neutrality by Japan and China,

1 London Times (Weekly), Feb. 26, 1904, p. 133.

2 Ibid.; also MSS. Dept. of State.

${ }^{8}$ MSS. Dept. of State.

4 On August 10, 1904, two Japanese torpedo-boat destroyers entered the harbor of Chefu and cut out the Russian destroyer "Ryeshitelni," which had taken refuge there, and which had, as the Russians alleged, assented to a Chinese demand for disarmament. The Russian government formally protested to the powers against the action of the Japanese as a gross violation of international law. Japan defended her action on the ground of the alleged violation of China's neutrality by Russia and the inability of China to enforce it. See London Times (Weekly), Aug. 19 and 22, 1904; and New York Times, Aug. 20, 1904. 
categorically pointing out: the Japanese capture of the "Ryeshitelni;" the alleged enlistment of Chinese bandits by the Japanese officers; the use of Miao-Dao Island as a base for naval operation by the Japanese fleet; the exportation of contraband from Chefu into Dalny (occupied by the Japanese force since May, I904); the furnishing of cast-iron to the Japanese army by the government shops of China at Hanyang. ${ }^{1}$ The governments of China and Japan not only promptly defended their conduct, but respectively made their counter-complaints against the Russian violation of the Chinese neutrality; submitting evidences of the sending of troops to Mongolia by Russia for the purposes of imposing military requisitions and of appropriating horses and provisions; of the Russian attempt in December last to smuggle ammunition at Kalgan for Port Arthur; of the establishment of wireless telegraphic apparatus at the Russian consulate at Chefu, which maintained communication with the fortress of Port Arthur; the military use of territory west of the Liao river by Russia; the forcing of the Chinese at Sinmintun to sell contraband to the Russian troops; and the escape of the Russian captain at Wasung while under escort from Chefu to Shanghai. ${ }^{2}$

More complex is the position of Korea. Its independence has been declared from time to time not only by Japan and Russia, but also by Great Britain, France and China. Prior to the Russo-Japanese war, Korea, on January 25, I904, declared her intention of maintaining neutrality in the event of war. ${ }^{8}$ But as north Korea was occupied by Cossacks and several other places by the Japanese, it became

1 MSS. Dept. of State.

2 Ibid.

8 The Korean government telegraphed to the foreign powers, through the French consul at Chefu, announcing its neutrality in the event of war between Japan and Russia. New York Herald, Jan. 25, 1904. 
the scene of military operations. Count Lamsdorff, in a circular note of February II, pointing out that, "before the opening of hostilities against Russia," Japanese troops were landed in Korea, and that Admiral Uriu had attacked Russian men-of-war in "the neutral port of Chemulpo," accused Japan of a flagrant breach of neutrality. ${ }^{1}$ In reply, the Japanese government sent to the powers, on March 9, a circular note in which it defended its action on the ground that its troops were despatched, with "the distinct consent of the Korean government," to "the menaced territory," in order to maintain " the independence and territorial integrity of Korea." 2 Japan further maintained that "a state of war" already existed when the Russian war vessels were attacked at Chemulpo, and that, Korea having consented to the landing of Japanese troops at Chemulpo, that harbor had already "ceased to be a neutral port, at least as between the belligerents." Professor Lawrence ably justifies the course of Japan, when he declares that "the power which struck the first blow within Korean borders violated no neutrality existing in actual fact, though a statepaper neutrality was rudely interfered with." ${ }_{3} \mathrm{He}$ observes that, although "Korea enjoyed a state-paper neutrality," she was in reality "prize of war." " In view of the grant by Korea to Japan of the right to land troops, and her failure to protest against the Japanese attack on the Russian vessels at Chemulpo, Dr. Nakamura regards her as a de-facto ally of Japan. ${ }^{\text {s }}$

Japan, through the efforts of Mr. Gonsuke Hayashi, her minister at Seoul, concluded on February 23, 1904, with

1 London Times (Weekly), Feb. 27, 1904, p. 132.

2 Ibid., March I1, 1904, p. 164.

3 Lawrence, War and Neutrality in the Far East, p. 216.

- Ibid., p. 81.

s Gaiko-Jiho, 1904, no. 81, pp. 545 et seq. 
the Korean government, a protocol defining her relations with that country. ${ }^{1}$ By this instrument Japan once more "guaranteed the independence and the territorial integrity of the Korean empire," and further "insured the safety and repose of the imperial house of Korea." Korea agreed to accept faithfully Japanese advice concerning the improvement of the administration, to grant to Japan the right to take all necessary measures and to occupy any places necessary from a strategic point of view, "in case the welfare of the imperial house of Korea, or the territorial integrity of Korea is endangered by the aggression of a third power, or by internal disturbances." But, while Japan guarantees Korean independence, she has, by virtue of her interference in administrative and military measures in the peninsula, established a de-facto protectorate over Korea. Here, again, Professor Lawrence well defines the Japanese relation to Korea when he says, "Susceptibilities are soothed, and possibly diplomatic difficulties turned, by calling it independent, but in reality it is as much under Japanese protection as Egypt is under ours [British], all state-paper descriptions to the contrary notwithstanding." 2 Japan further advanced her position as protector of Korea by the agreement made on August 22, $1904,{ }^{3}$ by which the Korean government cannot conclude treaties or conventions with foreign powers, or grant their subjects concessions, without previously having consulted the government of Japan. In April, 1905, the imperial government of Korea agreed to "transfer and assign the control and administration of the post, telegraph and telephone services in Korea (except the

1 The text of the protocol is given in Rockhill, Treaties and Conventions with or concerning China and Korea, p. 44I.

2 Lawrence, op. cit., p. 219.

8 The text of agreement of August 22 is found in the London Times. 
telephone service exclusively pertaining to the department of the imperial household) to the imperial Japanese government." 1

When Korea, however, in May, 1904, denounced all her treaties with Russia and all concessions granted to Russian subjects, the Russian government declared that it would "regard as null and void all acts of the Korean government while under Japanese tutelage." ${ }^{2}$ So long as Korea and Manchuria remained in the war-zone their status and destiny must have continued to be uncertain and conjectural. But by the Treaty of Portsmouth, Russia has recognized the Japanese protectorate over Korea, the open-door principle and the administrative entity of the Chinese government in Manchuria with the exception of the Liao-tung peninsula, re-leased to the Japanese. ${ }^{3}$ The renewed AngloJapanese alliance emphasizes that the Treaty of Portsmouth recognized, but also further secures, the open-door policy in Korea, notwithstanding the Japanese protectorate.

1 The Kwanpo, April 28, 1905, published the text of the agreement.

2 Lawrence, op. cit., p. 217.

8 See arts. ii-iv of the treaty of Portsmouth. 


\section{CHAPTER X}

\section{ConClusion}

Résumé.-From the foregoing chapters it may justly be assumed that certain nations of eastern Asia, though their rulers each claimed to be the lineal descendent of God, and exercised supreme authority in their own dominions, formed nevertheless, from very ancient times, "a family of nations," or international society, whose members acknowledged and observed certain usages, customs or rules in their intercourse in peace and war. In the international politics of Asia, the islanders of Japan, prior to the first century of the Christian era, inaugurated the system of interference in Korean affairs. During the time when Korea was composed of several kingdoms, the Mikado, his ministers and generals often exerted themselves to help the friendly kingdoms of Korea against neighboring aggressors. Even the Empress Zhingo invaded the Korean peninsula in person when the peace of Japan was menaced in the beginning of the third century. But, after the defeat in the naval war with the Emperor Tang of China, which resulted in the union of the several kingdoms of Korea and by which the Liao Tung peninsula became a Chinese possession, the Emperor Tenchi, in the middle of the seventh century, renounced the traditional policy of interference, and wisely concluded to maintain peaceful intercourse with both China and Korea. This august sovereign also, when he was crown prince, accomplished the Taika reformation, by which the imperial 483] 
sovereignty, usurped by the vassal Soga, was restored. Under the new peaceful régime of the imperial administration, Japan healthily assimilated the Indian, Chinese and Korean civilizations, which had been introduced during the previous centuries. Buddhism, Confucianism, the fine arts, literature, political and judicial institutions, reached the climax of their developments in the eighth century, a period known in Japanese history as "the enlightened eras of Nara and Haian."

For several hundred years after the close of the ninth century foreign intercourse, especially diplomatic intercourse, hardly existed among Asiatic nations. Military anarchy and civil war prevailed in Japan as well as in China, and piracy reigned on the high seas. The military anarchy in China developed into the universal militarism of the Mongol Tartar, which threatened the national states of the East and the West. Japan successfully defended her national existence against the universalism of Ghingis Khan in the thirteenth century. Three centuries later, at the end of the sixteenth century, the Japanese hero, Taiko Hideyoshi, tried to subjugate the Asiatic continent after the fashion of the Mongol Tartar, much as the Teutonic Frank had tried to unify Europe after the Roman fashion. But the "Napoleon of Japan," encountering disasters at home and abroad, learned the impossibility of realizing the dream of universalism.

As has heretofore been stated, the Japanese originally welcomed all European peoples. When the Portuguese and Spaniards, as the result of their discoveries of sea routes to the East, came to Japan in the sixteenth century, and when the English and Dutch followed them in the beginning of the next century, the government and people freely and cordially received them, giving these Europeans freedom of religion and of commerce and the privilege of 
extraterritoriality. Under these auspicious circumstances occidental and oriental nations should have been united into one international society. The Portuguese and Spanish missions to Asia, however, paid little or no respect to the sovereign rights of oriental nations. They undertook to divide all the world except the Christian countries between them, according to their construction of the Papal Bull. The abuses of the Catholic propaganda made it necessary for the Shogun government of Japan, in 1638 , to exclude all foreigners except a few Dutch and Chinese at Nagasaki. For two centuries and a quarter thereafter Japan held a position of international isolation. Differing from the Japanese, the Koreans and the Chinese hated the Europeans from the beginning. Even the faithful Dutch traders were not admitted to Korea. ${ }^{1}$ The first Portuguese embassy to China was imprisoned at Nanking. The Chinese did not grant to Europeans the privilege of extraterritoriality, as the Japanese had done. It is true that China did not totally close her ports, as did Japan and Korea, but she limited her intercourse with foreigners to Canton. The smuggling of opium by the English, who enjoyed a monopoly of the trade in that article with China, caused the Celestial empire, in I840, to declare foreign trade to be forever at an end. ${ }^{2}$ On the other hand, the nations of the East and the West, having widely different civilizations, could not be easily united unless one surrendered to the other. In the enlightened days of commerce and navigation the non-intercourse policy of the Asiatic nations infringed human necessity, and it was, therefore, against the "law of nations." Beginning with the opium war, Great Britain, France, the Netherlands, Russia and the United States exhibited a de-

1 Griffis, Corea, the Hermit Nation, pp. 166 et seq.

2 Boulger, History of China, vol. iii, p. 138. See also Douglas, Europe and the Far East, p. 67. 
termination to establish intercourse with Asia even by an - appeal to arms. After the bloody contest of the English and French with China, and the milder efforts of the Americans in Japan, western powers finally established commercial and diplomatic relations with Asiatic nations in the middle of the nineteenth century. Thus Japan and China were formally introduced into modern international society. They were not, however, members in the full sense of the word, as they had to recognize the extraterritorial privileges of the western nations, whose citizens did not feel safe under the local administration of justice. ${ }^{1}$

If a state be not internally organized according to the principles of the national consciousness, civil war or anarchy will predominate at home, and the national activity towards other nations will be hindered, and vice versa. The key to the political and social psychology of the Japanese is the fact that all Japanese subjects, official or individual, have absolute reverence for the imperial power as displayed in an unbroken line of illustrious Mikados. So long as this national consciousness is preserved, the country enjoys "tranquillity" at home and maintains the national glory abroad. This is witnessed by the history of ancient and modern Japan. In the middle ages, when the imperial power declined, the Shogun and daimios sprang up, and military anarchy became prevalent throughout the empire. Although the Shogun controlled the feudal daimios and ruled the empire, one Shogun after another was overthrown by a rival and there was no permanent peace. Naturally, steady intercourse with foreign countries was not maintained during the régime of the Shoguns. The best of the

of As to the inequality of members of the international society, owing to the different grades of civilization, see Westlake, International Law, pp. ror et seq. 
Shogun dynasties, that of the Tokugawa family, maintained the peace of the country for two centuries and a half, but it avoided the difficulties and responsibilities of foreign intercourse by maintaining a policy of seclusion. By the revolution of 1868 the imperial sovereignty was restored, and the state and government were again established on the fundamental idea of the Japanese-the national reverence for the Mikado. Ever since a marked evolution has been and still is in progress in the internal and external history of the empire. The feudal system has been replaced by the national régime. The national institutions have been equipped and improved by contact with western civilization, which has been freely adopted by the imperial government and adapted to the national needs. The military despotism and political tyranny of feudal Japan have been replaced by a constitutional system with parliamentary legislation, local self-government and courts of justice. Provincial loyalty to the feudal daimios succumbed to national patriotism and universal devotion to the emperor. The activities of the Japanese, which hitherto had been dissipated in the civil struggles of the feudal lords, came to be, under the auspices of internal peace, national activities reaching out toward external politics.

Japan's healthy assimilation of western civilization and her strenuous efforts for the revision of the old treaties induced the western powers to recognize her judicial autonomy. In 1899 she was admitted into the comity of nations on an equal footing with western states. In her intercourse with Asiatic powers modern Japan led the way in bringing her sister states into treaty relations and in providing for trade regulations and resident ministers, both of which had been utterly unknown in the international society of old Asia. Japan, however, to-day enjoys consular jurisdiction . in the territories of China, Korea and Siam, because her 
civilization is superior to theirs. In the domain of purely political questions among oriental nations, China and Japan were concerned in the solution of the Loochooan, the Formosan (1874-1875) and the Korean problems, in which Japan struggled to bring semi-civilized peoples to the light of modern civilization. The two empires of China and Japan had for twenty-five years, up to the Chinese-Japanese war, exercised a dominant influence upon oriental politics, just as the great powers of Europe maintained their supremacy in European diplomacy.

After the Chinese war of I894-1895, Japan entered into world-politics with the great powers of Europe and America. China was not only excluded from the rank of the Asiatic great powers, but became the "sick man" of the East, a companion of the "Korean invalid." Since that time the Far East has become a centre of the ambitions chiefly of France, Great Britain, Germany, Japan, Russia and the United States, in their efforts to satisfy the wants of " imperial expansion," commercial and political. As the result of Russia's efforts to obtain an ice-free port on the Pacific, Japan was not only "advised" to renounce her possession of the Liao Tung peninsula, "the legitimate fruit of victory," but was soon confronted with Russian rivalry in Korea. The continental powers of Europe claimed exclusive concessions in China, on the principle of "spheres of interest," while Great Britain, Japan and the United States maintained the principle of equality of opportunity for all nations in the commerce of the Far East. Among the continental powers, Germany, however, divides her preferences between the policy of "spheres of influence" and that of the "open door," while England and Japan, though they stand for the open-door policy, claim certain spheres of interest as an unavoidable necessity, in order to counterbalance the continental exclusiveness and 
secure the balance of power. But the United States, by reason of its detached position, was able freely, frankly and independently to espouse the open-door policy without claiming any sphere of interest, and to secure from the powers their pledge to maintain in China equality of commercial opportunity.

At the time of the Boxer complication in I900 the powers sent forces to North China for the relief of their representatives and citizens in Peking. But Russia afterwards failed to evacuate Manchuria and to restore to the Chinese government the temporarily assumed administration of Newchwang, a treaty port. Russia repeatedly excused her occupation of Manchuria as a temporary measure for railway protection. Nevertheless, more than once Russia attempted to induce China to conclude a treaty tending to impair China's sovereignty and to destroy the treaty rights of other powers. Great Britain, Germany, Japan and the United States warned China, while Great Britain, Japan and the United States from time to time protested directly to Russia. And as the latter country did not modify her evident designs in Manchuria, the Anglo-Japanese alliance was, in the beginning of 1902 , entered into as a precautionary measure. Influenced by this alliance and the independent representation of the United States, Russia concluded a convention with China, in April, 1902, by which Manchuria was to be restored to China. In accordance with the stipulations of this convention, Russia began, in October, I902, to evacuate Manchuria. But, in the spring of 1903 , she suddenly changed her attitude, not only suspending the withdrawal of her troops, but also increasing her forces in Manchuria as well as on the Korean frontier. Then, as a condition of evacuation, she made demands on China, the granting of which would practically have brought Manchuria under a Russian protectorate and excluded the commercial interests 
of all other powers. Great Britain, Japan and the United States again hastened to protest against the execution of the Russian designs.

Japan was far more directly concerned in the Far Eastern question than any other power, not only from the commercial point of view, but from the political as well. The permanent occupation of Manchuria by Russia and her activities in North Korea would be followed by the absorption of the whole of Korea, and this would menace the wellbeing of Japan. The imperial government of Japan, therefore, invited Russia to come to a thorough understanding by diplomatic means for assuring the integrity of the two "sick" nations of the Far East, and equal commercial opportunities therein for all nations, while recognizing the "predominant interest" of Russia in Manchuria and of Japan in Korea. Unfortunately, owing to the insincere attitude of the Russian government toward Japan, the latter was compelled to abandon measures of diplomacy and to take up arms to safeguard her interests. Notwithstanding the successive victories of Japan over Russia, Russia has not been "wiped out," but still remains a great power in Asia. What will be the ultimate result of the late great struggle between these two nations is a question that belongs to the future. Time will show whether the Far Eastern question will be solved by the supremacy of Russia, with her "policy of exclusiveness" and her "tradition of irresponsible authority," or by the leadership of Japan, who has, on the one hand, consciously adopted the Anglo-Saxon principle of national freedom and equality of opportunity, but who has, on the other hand, kindred sympathies and traditional relations with the backward nations of Asia.

The Mission of Japan.-It is the desire of Japan to pro serve in the Orient the national status of those of her sister Asiatic nations which are not yet subjugated by foreign 
powers, and to lead them to that light of western civilization which she is now enjoying, without having abandoned her national individualism. It is often said that the territorial integrity of the Chinese Empire is maintained by western powers largely because of the commercial interests involved. Japan not only has a dominant commercial interest, but she has also a political interest which far transcends that of any other power concerned in the Far Eastern question. As has often been observed, the Mikado and his statesmen have from time immemorial regarded the peace of the Korean peninsula as an object of vital importance to the welfare of Japan, and the preservation of Korean integrity has become the traditional policy of the Island Empire. For the attainment of this end Japan fought with China in 1894, with Russia in 1904, and will fight at any cost in the future with any power. From ancient times the Japanese have believed the extension of succor to weak Korea to be an "unshakable responsibility" of the empire. The recent protective measures adopted by Japan in Korea are, however, rather to be regarded as unavoidable aids to humanity and civilization. The Yamato-damashi, the "chivalrous spirit of the Japanese," which is derived from the Bushido (knighthood) - the readiness to help the weak victim as against the wicked aggressor-is particularly characteristic of the Japanese feeling toward Korea.

Though Japan had often been at enmity with China prior to the war of 1894, yet, when the latter's territorial integrity was threatened by foreign powers, she at once manifested her interest in the preservation of the Celestial empire. Japan's classical relation to Chinese civilization and her commercial growth in China further strengthen her political sympathy with that country. The new conditions that arose in Manchuria, under Russian influence, having direct connection with Korea, added greatly to the respon- 
sibilities of Japan. So long as China is incapable of maintaining single-handed an independent existence and of withstanding the external pressure of aggressive powers, Japan will not shirk her responsibility, even if called upon for armed assistance, as was demonstrated by the recent war. Mr. Colquhoun several years ago suggested the importance of preserving Chinese independence " under the tutelage of Japan, by the concert of commercial . powers of Europe and America." 1 The civilized nations of the West should have faith in Japan's leadership in helping China, because Japan has not only pledged herself to maintain Chinese territorial integrity and the open-door

1 policy in public documents, but has also ever fulfilled this pledge in practice.

- Although Japan is politically not so much concerned with Siam as is either Great Britain or France, the modern Siamese cannot have forgotten the chivalrous assistance rendered them by the brave Yamada Masanaka on the eve of their national crisis in the seventeenth century. ${ }^{2}$ Ever since the first treaty engagement of 1887 , cordial relations between Japan and Siam have been maintained, and they have been more closely cemented by the recent visit of the Siamese crown prince to Tokio. Before any other power, Japan formally manifested her willingness to recognize Siam's entrance into the "comity of nations." The Japanese trade with Siam has developed to a significant degree during several years past, and there is also a marked possibility of further expansion. In case of territorial danger to Siam, Japan would not keep silence.

- On the other hand, Japan would educate the backward

1 Colquhoun, The Mastery of the Pacific, p. 426.

${ }^{2}$ For an interesting account of Yamada in Siam, see a paper by Captain James, Transactions of the Asiatic Society of Japan, vol. vii, pp. 194-199. 
nations of Asia in western civilization. She has from time to time advised both Korea and China to reform their corrupt administration, which does not sufficiently guarantee the safety of person and property, and which tends to create foreign complications; but she has acquired, as the result of the failure of radical reforms in Korea in 1895, and in China in 1898 , a preference for gradual measures. A number of Japanese legal counselors, administrative advisers, military instructors and college professors have already been employed by the Chinese, Korean and Siamese governments. Young men of these nations are also flocking to Tokio for professional education. By reason of kindred ideas and a kindred literature, the Japanese, as Dr. Hirth has remarked, are more capable than Europeans and Americans of so educating the Chinese as not to destroy "the old knowledge while familiarizing the students with the advantages of the new." 1

Meanwhile Japan's activity in the Far East, particularly with reference to the potential awakening of China, with its extensive territories and vast population, has aroused the jealousy of rival powers. An attempt is made to create antagonism to her mission in China by invoking the apparition of the "yellow peril," which is supposed to endanger western civilization. From the economic point of view, the "yellow peril" is interpreted to signify that all western trade would be excluded from China should the Chinese, awakened by Japan, develop their industrial resources with "cheap labor" and thus supply themselves. The argument is superficial and erroneous. Many eminent economists now hold that a low scale of wages and of living succumbs in the long run to a higher scale of wages and of

1 The World's Work, May, I903. 
living in modern industrial competition. ${ }^{1}$ The introduction of modern industries into Japan, moreover, made the Japanese " far better customers in European and American markets," because of their new wants. The commercial history of Japan is instructive as to the future demands of the Chinese on western markets. "The richer the Chinese get, the more they will buy." ${ }^{2}$

Then, from the military point of view, it is suggested that the Japanese will drill the Chinese into efficiency by means of modern discipline, and that the combination of Japan with an empire of four hundred million people will endanger the western nations just as the Mongol hordes threatened Europe in the thirteenth century. Count Cassini, the Russian ambassador at Washington, openly deprecated the success of the Japanese in the late war, on the ground that it "would make the Japanese dominant in Asia and result in an Asiatic league," which "would imperil the interests not only of Europe, but of America also." 3 This argument Baron Kaneko has ably refuted." "We are," he declares, " not fighting that we may be regarded as a 'peril' to western civilization, but to maintain the progress and humanity of Asiatic peoples." The Japanese are teaching the Chinese nationalism, how to defend their empire and to win the respect of other nations, in opposition to the universal anarchy of the Mongol hordes. So long as China is unable to defend herself, Japan is dis-

${ }_{1}$ Schoenhof, The Economy of High Wages, chaps. iii, iv and v. Marshall says that "low-wage labor is generally dear, if working with expensive machinery." See his Principles of Economics, 4th ed., bk. vi, chap. iii, p. 631.

${ }^{2}$ Leroy-Beaulieu, The Awakening of the East, p. 239 . See also Reinsch, World Politics, p. 250.

${ }^{3}$ New York World, March 20, 1904.

* International Economist, May 2I, 1904. 
posed to sympathize with and encourage her, and, if necessary, to act in alliance with her. But, if the Chinese should pursue a course offensive to western civilization, the Japanese would co-operate with Christendom, hand in hand, against them, just as they did in I900, when the Boxers treacherously offended against civilization and international law. Living authorities on the Far Eastern question, like Colquhoun, Stevens and Reinsch, have clearly exposed the absurdity of the cry as to the "yellow peril," and have demonstrated the absence of any ground for apprehension in Japan's attitude towards China. ${ }^{1}$

Western civilization may, on the contrary, have something to fear from the "Slavic peril." Professor Burgess, an authority of world-wide reputation on public law and western history, has affirmed that the position of Russia constitutes "a perpetual and fearful menace to Germany, Austria and Sweden-Norway;" and he has further ventured to prophesy that "Russia will prove herself, in the next twenty-five years, almost as hostile to the United States as she is now to Great Britain." 2 Several years ago, when Russia occupied Port Arthur, and when the rumor of a Russo-Chinese alliance prevailed, Professor Giddings, ${ }^{3}$ an eminent sociologist, declared that the English-speaking nations would "lose commercial opportunities," would "sink to a position of secondary influence," and would "presently find themselves obliged to conform in all their politics to a power that will dominate international relations as remorselessly as did Cæsar or Napo-

1 Colquhoun in The Independent, April 14, 1904; Stevens in The Forum, vol. 30, pp. 76-85; Reinsch in The North American Review (1905), no. I.

2 Political Science Quarterly, vol. xix, pp. 16-18.

s Ibid., vol. xiii, p. 605. 
leon," unless Great Britain and the United States should abandon their "selfish and short-sighted" antagonism and act together against the Russo-Chinese combination, with its "policy of exclusiveness" and its "tradition of irresponsible authority." It is a historical fact that the commerce of Japan, and of other commercial nations, in North China and in Korea has from time to time been menaced by Russian activities. The cry of "peril" is, however, often the utterance of a jealousy of the temporarily dominant influence of some particular power. The greater the surplus produced by the United States for export, the louder the outcry of the continental powers against the "Yankee peril." The great powers and their material forces are to-day widely distributed over the earth, and they are watching with keen jealousy to see that no highhanded measure of any particular power endangers the rest of the world. The peril may be Yellow, Slavic, or Yankee, but its realization is not in the near future.

As to the attitude of Japan toward the western nations, it may be observed that she has welcomed and appreciated their appearance in the East, without which she recognizes the fact that Asia could not have been awakened. The political, commercial and religious agencies of the West, equipped with adequate capital, modern machinery and an organized church, are important factors in the exploitation of undeveloped Asia and its education in modern ideas. Japan therefore will co-operate with the western nations in the great work of civilization in Asia. Though opposed to the exclusive exploitation and permanent occupation of Manchuria by Russia, she was once ready to recognize Russia's dominant interest there, both commercial and political, especially in the matter of railways. Count Katsura, prime minister, declared, in the House of Representatives, in April, 1904, that it was "the policy of this empire to 
cement close relations with the treaty powers, to respect the rights due to other nations, and thus to promote the maintenance of permanent peace in the Far East, as well as to strengthen the position of the country." ${ }^{1}$ In these days, when the oriental and the occidental civilizations meet face to face, the function of Japan is indispensable, since she is familiar with the characteristics of both. During his tour of the world, in I90I, Marquis Ito gave an interesting explanation of Japan's mission in a speech at the Metropolitan Club in New York City. "We are," said he, "the only people in the Orient who can fully understand the importance and significance of two civilizations, and I consider it a noble mission of our country to to mplay the part of international broker in the further bantenance of the peace of the Orient." 2 . The national aspiration of the Japanese is, in a word, to maintain permanent international peace and peaceful intercourse, commercial and political, among all nations of the East and the West, preserving the territorial integrity of the weaker nations of Asia by cooperation with the great powers, while respecting the legitimate rights of other nations and defending its own proper rights and dignity. In the foreign affairs of the empire, the ruling emperor, the most gracious and august sovereign of Japan, has sedulously taught his people and government " to develop a cordial and amicable understanding with the treaty nations as the basis of enduring peace." During the deadlock at Portsmouth, which threatened to break up the negotiations for the termination of the great war, the emperor, sacrificing the claim for a large indemnity, commanded his plenipotentiaries to concede the Russian conditions simply "for the sake of humanity and civilization"

1 The Japan Weekly Mail, March 26, 1904.

2 New York Times, October 25, 1901. 
and " in the interest of both countries [Japan and Russia] and the world."

The peace of the world conceivably might be maintained by a universal sovereignty over all nations. ${ }^{1}$ The institution of universalism, like Roman imperialism, dominating all the nations, may theoretically solve international conflicts. Universal authority would, however, necessarily destroy national peculiarity and ultimately bring about "stagnation and despotism." 2 Modern nations really struggle against universalism in order to preserve their own con- sciousness. So long as nations have no world-language or world-literature and no universal consciousness of right and wrong, long as national patriotism is not converted into world cosmopolitanism, the world peace of universalism cannot come into existence. The present emperor of Rusșia, has, out of the benevolence of his disposition, proposed to maintain international peace as well as to lighten national burdens by limiting the military forces of nations. ${ }^{8}$ But the history of the world does not justify the assumption that such a policy would necessarily have that practical result. The national wealth-public and private-of the leading powers is steadily increasing, in spite of their progressive armaments. No progressive nation desires to reduce her armament or her independent activities in days in which arms are still the best guarantee of peace and prosperity and

1 Seligman, The Economic Interpretation of History, p. I29.

${ }^{2}$ Burgess, Political Science and Comparative Constitutional Law, vol. i, p. 38 .

${ }^{3}$ See the rescript of Czar, dated August 24, 1898, and the circular note of Count Muravieff, dated Jan. II, I899, in Holls, The Peace Conference at the Hague, pp. 8-10, 24-27. For the objection to disarmed peace, see the speech of General von Schwarzhoff, the German delegate to the Peace Conference, ibid., pp. 76-78. See also a paper of Capt. Mahan, the American delegate, North American Review, vol. I69. 
of the maintenance of national dignity. The principle of "arms against arms" is still true and practical. Since Prince Bismarck established the condition of "armed peace," the progressive armaments of the powers composing the Triple Alliance and the Dual Alliance, the steady development of the powerful navy of Great Britain, and the increased preparation of the Americans to help their sister republics with formidable ironclads, are but the tokens of international peace in Europe and America. Prior to the outbreak of the Russo-Japanese war, the Anglo-Japanese alliance, concluded in 1902, was regarded as at least a precautionary measure in securing the open-door policy and the peace of the Far East. The renewed Anglo-Japaneses alliance concluded on August 12, I905, which has extended the territorial operation of the compact so as to cover eastern Asia and India, should insure the general peace of Asia as against attempts at revenge by the rival power. ${ }^{1}$

Armed peace is particularly necessary in the case of international trade. Commerce is often described as a peacemaker, since it is mutually beneficial to all nations. This statement is but an exaggeration of the idea of free trade. Should the industries and the transportation of nations develop in an equal degree, should nations have equal productive power and international exchange take place on an equal footing, then mutual benefit would be enjoyed by all nations and there would be no colonial struggles and no commercial jealousies. But, until nations shall attain this ideal commercial peace as the result of freedom of exchange, they must heed historical precedents. Speaking historically, commerce and war have a significant relation. "Even when the two are distinct,". says Professor Cunningham, "they are closely connected; for war may open up new

1 See Appendix B. 
points for commerce, as was done by the Crusades, and a successful war may give securities for peaceful commerce; on the other hand, commercial rivalries have often occasioned the outbreak of hostilities between nations." 1 During the seventeenth and eighteenth centuries, the international trade of European nations was characterized by mercantilism, "the national economy of self-interest." Most of the wars were waged for economic objects; the alliances were often formed against the monopolistic measures of the dominant powers. ${ }^{2}$ The victory of Great Britain over $\mathrm{Na}$ poleonic France for a long time secured peaceful commerce. Meanwhile, the economic theories of Quesnay and Adam Smith, translating " natural law" into international trade, caused nations to modify the restrictions of selfish mercantilism. Their adherents advocated "free trade," and in the middle of the nineteenth century western nations were influenced by cosmopolitanism in their foreign commercial policy. German economists, notably Friedrich List, ${ }^{8}$ however, clearly demonstrated, with characteristic thoroughness, that free trade might be favorable to countries where industries were developed to a high degree, such as Great Britain, but not to such countries as Germany or the United States, which were in transition from the agricultural to the manufacturing stage, and that protective measures were preferable for the latter in order to foster " infant industries." In the latter part of the nineteenth century, the United States, the German Empire, France, Austria-Hungary, Italy and Russia, established highly protective tariffs."

1 Cunningham, Western Civilization (Ancient Times), p. 3.

${ }^{2}$ Schmoller, The Mercantile System, pp. 50-68.

3 Bastable, The Commerce of Nations, pp. 123 et seq.; Ingram, $A$ History of Political Economy, pp. 193 et seq.

4 Bliss, The Encyclopedia of Social Reform. See also Seager, Introduction to Economics, pp. 370 et seq. Ashley, Modern Tariff History. 
Even in England, where the free-trade doctrine has remained dominant, the cry of "protection against protection" has grown louder in the beginning of the twentieth century. ${ }^{1}$ Although Japan was obliged to establish liberal rates in her conventional tariff, her statutory tariff is based upon the protective principle. ${ }^{2}$ Protective measures have in their progress come to embrace subsidies on shipping and railway transportation, bounties on exports, the federation of colonies, the expansion of "spheres of interest," and the acquisition of leases and concessions in the territories of inferior nations. The economic activity of the great powers has assumed the form of "imperialism," which signifies the ambition of the great powers to control, for economic or political purposes, " as large a portion of the earth's surface as their energy and opportunities may permit." The struggle of the great powers in China is strikingly imperialistic. $^{\mathbf{8}}$ Should Russia maintain exclusive control in her imperial expansion in China and should the other great powers be indulgent toward her policy, their commercial opportunity in that quarter would be lost. The open-door policy in China can be maintained only by arms, so long as diplomacy fails to make Russia recognize the rights of other powers. The commercial and colonial policy of the Dutch in the eighteenth century is very instructive. Their avoidance of political responsibility in the pursuit of commerce led to the downfall of their colonial empire. ${ }^{4}$ It is

1 See Mr. Chamberlain's speech, May 15, 1903, at Birmingham, London Times, May 16, 1903.

2 The statutory tariff of 1899 was amended in 1901 and again in 1904, and the rates of duty were increased. See the Kwampo, March 30, I90I, and January I, 1905.

s Reinsch, World Politics, parts ii, iii. See also Hobson, Imperialism, chap. v, "Imperialism in Asia."

4 Cunningham, Western Civilization, vol. ii, pp. 204 et seq. 
still true that "the flag follows trade," and vice versa. Struggles of the nations will not cease until "economic equality" is secured among them. ${ }^{1}$ The armed protection of commerce is also indispensable for neutral countries in time of war. For the enforcement of the rule "free ships, free goods," Catherine II initiated the so-called armed neutrality against the discriminative capture of neutral ships by belligerent powers. ${ }^{2}$ In short, the peaceful and defensive measure of arms is based on experience and human necessity. In their contemporary speeches, Emperor William, King Edward, President Roosevelt, and Marquis Ito frankly admit the necessity of armaments in maintaining the peace of nations. ${ }^{8}$

Armed peace is, however, likely to be misused or to be abused by passionate statesmen or by selfish nations. It is, therefore, much to be desired that, while nations maintain armaments as a safeguard, their differences should be settled, for the advancement of international peace, by " the subtler

1 Seligman, The Economic Interpretation of History, p. I30.

- ${ }^{2}$ As to the armed neutrality, see Wheaton, History of the Law of Nations, par. I4.

${ }^{3}$ During the imperial regatta at Kiel, on June 25, 1904, the German emperor, responding to a toast to King Edward, spoke as follows of the German navy: "It is intended for the protection of trade and of territory, and it also serves, like the German army, for the maintenance of peace which the German Empire has kept more than thirty years, and which Europe has preserved with it." King Edward responded: "May our two flags float side by side to the remote ages, even as to-day, for the maintenance of peace and welfare not only of our own countries, but also of all other nations." New York Herald, June 26, 1904.

"We desire," President Roosevelt, referring to the navy, declared in his annual message of 190r, "the peace which comes as of right to the just man; not the peace granted on terms of ignominy to the craven and the weakling."

Marquis Ito said two years ago: "We are arming ourselves only to insure the fulfilment of the mission of peace and the progress we have made thus far." See his speech at the Metropolitan Olub. 
movement" of diplomacy. The Peace Conference at the Hague certainly marks a great step towards general peace, so far as civilized countries have pledged themselves to submit their differences to impartial investigation, or to mediation or arbitration. The English-speaking nations, which have an extensive commerce throughout the globe, have long since manifested their sincere disposition to settle their disputes by arbitration. The United States during the last century was a party to " fifty-three executed arbitral agreements;" and its "president, or some one appointed or approved by him," acted as " arbitrator or umpire" in " twelve cases." 1 Great Britain was a party to twenty arbitrations with the United States and to thirty-three with other countries. $^{2} \quad$ The recent course of some of the great powers, particularly Great Britain, France, Germany, Italy and Spain, in agreeing to refer to the Hague tribunal differences which do not affect " the vital interests, the independence or the honor" of the state, has tended to rescue the tribunal from neglect. If this course were generally followed, international friction would be diminished. Japan and Russia, now that the war is ended, should return to the support of this humane movement.

In I902 Japan consented to the submission to the Hague tribunal of the question of the application of the house tax to buildings of foreign residents on land held under lease in perpetuity. ${ }^{3}$ Even while the war was still in progress the negotiation of an arbitration treaty between Japan and the United States was reported. Russia also concluded a similar treaty with Denmark.

1 Moore, A Hundred Years of American Diplomacy, Rep. of Am. Bar Asso., vol. 27, pp. 347 et seq.

2 Ibid., p. 351.

3 Parl. Papers, Japan no. I (1905). On May 22, 1905, the tribunal decided against the Japanese claim. 
It is no doubt true that the commercial and colonial jealousies attending the imperial expansion of the great powers would be softened by observing the spirit of cosmopolitanism, as exhibited in the open-door policy. ${ }^{1}$ The Anglo-French agreement of April $7,1904,{ }^{2}$ which adjusted the differences of the two countries in respect of their colonies, and which liberally adopted the cosmopolitan policy, is suggestive and instructive in its bearing on the imperialistic policy of the great powers. Reciprocity treaties, the liberal application of the "most-favored-nation" clause, and the extension of national treatment to foreigners, would go far towards averting tariff wars and retaliation. Finally it should be remembered that, although an imperialistic policy may be justified, where it is confined to the protection of the legitimate rights of the nation abroad, or where it leads backward nations to the light of civilization, or even where it secures the necessary exercise of an "international police," yet a selfish imperialism is likely to end, as it has so often done, only in failure. The measures of the Anglo-Japanese alliance in China and Korea such as the open-door policy are both humane and statesmanlike.

The peace of the world, the progress of humanity, the prosperity of each individual nation, the reconciliation of the East and West, the union of the "Christian" and the "Pagan," all the elements that go to make up the great conception of the world's civilization, would be advanced by the co-operation of all nations which are capable of such

1 "In so far as any country finds that she is able, without detriment to herself, to modify or reconstruct her commercial policy on cosmopolitan lines, the occasions for international dispute are likely to be considerably diminished." Cunningham, Western Civilization, vol. ii, p. 266.

2 Parl. Papers, France no. I (1904). 
a mission. In this all-embracing world-movement, Japan will continue to play a significant part, as she has done heretofore, in harmony with her own interests and with those of Christendom, and in the same chivalrous spirit in which she is now leading her sister nations of Asia to a higher plane of political, social, and moral responsibility. 


\section{APPENDIX}

The Treaty of Portsmouth, 1905

The Emperor of Japan, on one part, and the Emperor of All the Russias, on the other part, animated by a desire to restore the blessings of peace to their countries, have resolved to conclude a treaty of peace and have for this purpose named plenipotentiaries, that is to say, for his Majesty, the Emperor of Japan, Baron Komura Jutaro Jusami, Grand Cordon of the Imperial Order of the Rising Sun, his Minister for-Foreign Affairs, and his Excellency Takahira Kogoro, Imperial Order of the Sacred Treasure, his Minister to the United States, and for his Majesty the Emperor of All the Russias, his Excellency LSergius Witte, his Secretary of State and Bresident of the Committee of Ministers of the Empire of Russia, and his Excellency Baron Roman Rosen, Master of the Imperial Court of Russia his Majesty's Ambassador to the United States Who, after having exchanged their full powers, which were found in good and due form, have concluded the following articles:]

inthe futuke

Article One.-There shall henceforth be beace and amity between their Majesties the Emperor of Japan-and the Emperor of All the Russias and between their respective) States and subjects. 
Article Two.-The Imperial Gussian Gavernment; aeknowledging that Japan possesses in Korea paramount political, military, and economical interests, engage nfeither to obstruet nor interfere 1 with measures for the gurfance, protection, and control which the Imperial Government of Japan recogrizy not may find + it necessary to take in Korea.

$\overline{\mathrm{It}}$ is understood that Russian subjects in Korea shall be treated in exactly the same manner as the subjects and citizens of other foreign powers; that is to say, they shall be placed on the same footing as the subjects and citizens of the most favored nation.

It is also agreed that in order to avoid causes of misunderstanding the two high contracting parties will abstain on the Russian-Korean frontier from taking any military measures which may menace the security of Russian or Korean territory.

Article Three.-Japan and Russia mutually engage:

First-To evacuate completely and simultaneously Manchuria except the territory affected by the lease of the Liaotung Peninsula in conformity with the provisions of the additional Article I annexed to this treaty, and

Second-To restore entirely and completely to the exclusive administration of China all the portions of Manchuria now in occupation or under the control of the Japanese or Russian troops with the exception of the territory above mentioned.

The Imperial Government of Russia declare that they have not in Manchuria any territorial advantages or preferential or exclusive concessions in the impairment of Chinese sovereignty or inconsistent with the principle of equal opportunity.

Article Four.-Japan and Russia reciprocally engage not to obstruct any general measures common to all countries 
which China may take for the development of the commerce or inclustry of Manchuria.

Article Five.-The Imperial Russian Government transfer and assign to the Imperial Government of Japan, with the consent of the Government of China, the lease of Port Arthur, Ta-Lien, and the adjacent territory and territorial waters and all rights, privileges, and concessions connected with or forming part of such lease, and they also transfer and assign to the Imperial Government of Japan all public works and properties in the territory affected by the abovementioned lease.

The two contracting parties mutually engage to obtain the consent of the Chinese Government mentioned in the foregoing stipulation.

The Imperial Government of Japan on their part undertake that the proprietary rights of Russian subjects in the territory above referred to shall be perfectly respected.

Article Six.-The Imperial Russian Government engage to transfer and assign to the Imperial Government of Japan without compensation and with the consent of the Chinese Government the railway between Chang-chun-fu and Kuanchang-tsu and Port Arthur, and all the branches together with all the rights, privileges, and properties appertaining thereto in that region, as well as all the coal mines in said region belonging to or worked for the benefit of the railway. The two high contracting parties mutually engage to obtain the consent of the Government of China mentioned in the foregoing stipulation.

- Article Seven.-Japan and Russia engage to exploit their respective railways in Manchuria exclusively for commercial and industrial purposes and nowise for strategic purposes. It is understood that this restriction does not apply to the railway in the territory affected by the lease of the Liaotung Peninsula. 
Article Eight.-The Imperial Governments of Japan and Russia, with the view to promote and facilitate intercourse and traffic, will so soon as possible conclude a separate convention for the regulation of their connecting railway services in Manchuria.

Article Nine.-The Imperial Russian Government cede to the Imperial Government of Japan in perpetuity and full sovereignty the southern portion of the Island of Sakhalin and all the islands adjacent thereto and the public works and properties thereon. The fiftieth degree of north latitude is adopted as the northern boundary of the ceded territory. The exact alignment of such territory shall be determined in accordance with the provisions of the additional Article $\mathrm{XI}$ annexed to this treaty.

Japan and Russia mutually agree not to construct in their respective possessions on the island of Sakhalin or the adjacent islands any fortifications or other similar military works. They also respectively engage not to take any military measures which may impede the free navigation of the Strait of La Perouse and the Strait of Tartary.

Article Ten.-It is reserved to Russian subjects, inhabitants of the territory ceded to Japan, to sell their real property and retire to their country, but if they prefer to remain in the ceded territory they will be maintained and protected in the full exercise of their industries and rights of property on condition of submitting to the Japanese laws and jurisdiction. Japan shall have full liberty to withdraw the right of residence in or to deport from such territory any inhabitants who labor under political or administrative disability. She engages, however, that the proprietary rights of such inhabitants shall be fully respected.

Article Eleven.-Russia engages to arrange with Japan for granting to Japanese subjects rights of fishery along the 
coasts of the Russian possessions in the Japan, Okhotsk, and Bering Seas.

It is agreed that the foregoing engagement shall not affect rights already belonging to Russian or foreign subjects in those regions.

Article Twelve.-The treaty of commerce and navigation between Japan and Russia having been annulled by the war, the Imperial Governments of Japan and Russia engage to adopt as a basis for their commercial relations, pending the conclusion of a new treaty of commerce and navigation, the basis of the treaty which was in force previous to the present war, the system of reciprocal treatment on the footing of the most favored nation in which are included import and export duties, customs formalities, transit and tonnage dues, and the admission and treatment of agents, subjects, and vessels of one country in the territories of the other.

Article Thirteen.-So soon as possible after the present treaty comes in force all prisoners of war shall be reciprocally restored. The Imperial Governments of Japan and Russia shall each appoint a Special Commissioner to take charge of the prisoners. All prisoners in the hands of one Government shall be delivered to and received by the Commissioner of the other Government or by his duly authorized representative in such convenient numbers and such convenient ports of the delivering State as such delivering State shall notify in advance to the Commissioner of the receiving State.

The Governments of Japan and Russia shall present each other so soon as possible after the delivery of the prisoners is completed with a statement of the direct expenditures respectively incurred by them for the care and maintenance of the prisoners from the date of capture or surrender and up to the time of death or delivery. Russia engages to repay to Japan so soon as possible after the exchange of 
statement as above provided the difference between the actual amount so expended by Japan and the actual amount similarly disbursed by Russia.

Article Fourteen.-The present treaty shall be ratified by their Majesties, the Emperor of Japan and the Emperor of All the Russias. Such ratification shall be with as little delay as possible, and in any case no later than fifty days from the date of the signature of the treaty, to be announced to the Imperial Governments of Japan and Russia respectively through the French Minister at Tokio and the Ambassador of the United States at St. Petersburg, and from the date of the later of such announcements this treaty shall in all its parts come into full force. The formal exchange of ratifications shall take place at Washington so soon as possible.

Article Fifteen.-The present treaty shall be signed in duplicate in both the English and French languages. The texts are in absolute conformity, but in case of a discrepancy in the interpretation the French text shall prevail.

In conformity with the provisions of Articles 3 and 9 of the treaty of peace between Japan and Russia of this date the undersigned plenipotentiaries have concluded the following additional articles:

Sub-Article to Article Three. - The Imperial Governments of Japan and Russia mutually engage to commence the withdrawal of their military forces from the territory of Manchuria simultaneously and immediately after the treaty of peace comes into operation, and within a period of eighteen months after that date the armies of the two countries shall be completely withdrawn from Manchuria except from the leased territory of the Liao-tung Peninsula. The forces of the two countries occupying the front positions shall first be withdrawn. 
The high contracting parties reserve to themselves the right to maintain guards to protect their respective railway lines in Manchuria. The number of such guards shall not exceed fifteen per kilometer, and within that maximum number the commanders of the Japanese and Russian Armies shall by common accord fix the number of such guards to be employed as small as possible while having in view the actual requirements.

The commanders of the Japanese and Russian forces in Manchuria shall agree upon the details of the evacuation in conformity with the above principles, and shall take by common accord the measures necessary to carry out the evacuation so soon as possible, and in any case no later than the period of eighteen months.

Sub-Article to Article Nine.-So soon as possible after the present treaty comes into force a commission of delimitation, composed of an equal number of members, is to be appointed, respectively, by the two high contracting parties, which shall on the spot mark in a permanent manner the exact boundary between the Japanese and Russian possessions on the island of Sakhalin. The commission shall be bound, so far as topographical considerations permit, to follow the fiftieth parallel of north latitude as the boundary line, and in case any deflections from that line at any points are found to be necessary, compensation will be made by correlative deflections at other points. It shall also be the duty of said commission to prepare a list and a description of the adjacent islands included in the cession, and, finally, the commission shall prepare and sign maps showing the boundaries of the ceded territory. The work of the commission shall be subject to the approval of the high contracting parties.

The foregoing additional articles are to be considered ratified with the ratification of the treaty of peace to which they are annexed. 
Portsmouth, the fifth day of the ninth month of the thirtyeighth year of Meiji, corresponding to the twenty-third of August, 1905, (Sept. 5, 1905).

In witness whereof the respective plenipotentiaries have signed and affixed seals to the present treaty of peace.

Done at Portsmouth, New Hampshire, this fifth day of the ninth month of the thirty-eighth year of the Meiji, corresponding to the twenty-third day of August, one thousand nine hundred and five. 
The Anglo-Japanese Alliance, 1905

Preamble.-The Governments of Great Britain and Japan, being desirous of replacing the agreement concluded between them on January 30, 1902, by fresh stipulations, have agreed upon the following articles, which have for their object:

$A$.-Consolidation and the maintenance of general peace in the regions of eastern Asia and India.

$B$.-The preservation of the common interests of all the Powers in China by insuring the independence and integrity of the Chinese Empire and the principle of equal opportunities for the commerce and industry of all nations in China.

C.-The maintenance of the territorial rights of the high contracting parties in the regions of eastern Asia and of India, and the defense of their special interests in the said regions.

Article I. It is agreed that whenever, in the opinion of either Great Britain or Japan, any of the rights or interests referred to in the preamble are in jeopardy, the two Governments will communicate with one another fully and frankly, and consider in common the measures which should be taken to safeguard those menaced rights and interests.

Article II. If, by reason of an unprovoked attack or aggressive action, wherever arising, on the part of any other Power or Powers, either contractor be involved in war in defense of its territorial rights or special interests men282 
tioned in the preamble, the other contractor shall at once come to the assistance of its ally, and both parties will conduct war in common and make peace in mutual agreement with any Power or Powers involved in such war.

Article III. Japan possessing paramount political, military, and economic interests in Korea, Great Britain recognizes the right of Japan to take such measures for the guidance, control, and protection of Korea as it may deem proper and necessary to safeguard and advance those interests, provided always that such measures are not contrary to the principle of equal opportunities for the commerce and industry of all nations.

Article IV. Great Britain having special interests in all that concerns the security of the Indian frontier, Japan recognizes her right to take such measures in the proximity of that frontier as she may find necessary for safeguarding her Indian possessions.

Article $V$. The high contracting parties agree that neither, without consulting the other, will enter into separate agreements with another Power to the prejudice of the objects described in the preamble of this agreement.

Article VI. In the matter of the present war between Japan and Russia Great Britain will continue to maintain strict neutrality unless another Power or Powers join in hostilities against Japan, in which case Great Britain will come to the assistance of Japan, will conduct war in common, and will make peace in mutual agreement with Japan.

Article VII. The conditions under which armed assistance shall be afforded by either Power to the other in the circumstances mentioned in the present agreement, and the means by which such assistance shall be made available, will be arranged by the naval and military authorities of the contracting parties, who from time to time will consult one another fully and freely on all questions of mutual interest. 
Article VIII. The present agreement shall, subject to the provisions of Article VII, come into effect immediately after the date of signature and remain in force for ten years from that date. In case neither of the high contracting parties shall have been notified twelve months before the expiration of the said ten years of the intention of terminating the agreement, it shall remain binding until the expiration of one year from the day on which either of the contracting parties shall have denounced it; but if, when the date fixed for its expiration arrives, either ally is actually engaged in war, the alliance, ipso facto, shall continue until peace shall have been concluded.

In faith whereof the undersigned, duly authorized by their respective Governments, have signed this agreement and affixed their seals. Done in duplicate at London, August 12, 1905.

LANSDOWNE. HAYASHI. 


\section{LIST OF AUTHOFITIES}

Adams, F. O. The History of Japan. 2 vols. London, 1875. Annual Register.

Ariga, N. Kokuho-gaku (Public Law of Japan). 2 vols. Tokyo, 1901. Ariga, N. La Guerre Sino-Japonaise. Paris, 1896.

Ashley, Modern Tariff History. New York, I904.

Bastable, C. F. The Commerce of Nations. London, 1899.

Beneditti, C. Studies in Diplomacy. New York, 1896.

Bismarck's Autobiography. Butler's edition. 2 vols. New York, 1899.

Black, J. R. Young Japan. 2 vols. Yokohama, 1880.

Bluntschli, J. K. The Theory of the State. Oxford, 1892.

Boulger, D. C. History of China. 3 vols. London, 1881.

Bliss, W. D. P. The Encyclopcdia of Social Reform. New York, 1897.

Brinkley, Captain. History of the Empire of Japan. Tokyo, 1893.

Bryce, J. Holy Roman Empire! New York, 1877.

Burgess, J. W. Political Science and Comparative Constitutional Law. 2 vols. Boston, 1898 .

Burrows, M. The History of the Foreign Policy of Great Britain. New York, 1895.

Chamberlain, B. H. Things Japanese. Tokyo, 1890.

Charlevoix. Histoire du Japon. Tours, 1842.

Cocks's (Richard) Diary (I6I5-1622). New York, 1902.

Colquhoun, A. R. The Mastery of the Pacific. New York, 1902.

Cordier, H. Histoire des relations de la Chine avec les puissances occidentales. 3 vols. Paris, I902.

Cunningham, W. An Essay on Western Civilization in its Economic Aspects. 2 vols. Cambridge, 1898 and 1900.

Curzon, G. N. Problems of the Far East. Westminster, 1896.

Debidour, A. Histoire diplomatique de l'Europe. 2 vols. Paris, 1891.

Denning. Life of Toyotomi Hidcyoshi.

Douglas, R. K. Europe and the Far East. Cambridge, 1904.

Drace, G. Russian Affairs. London, 1904.

Duggan, S. P. H. The Eastern Question. New York, 1902.

Dyer, T. H. History of Modern Europe. 5 vols. London, 1877.

Forster, J. W. American Diplomacy in the Oricnt. Boston, 1903.

Fraissinet, F. E. Le Japon. 2 vols. Paris. 
Freeman, E. A. General Sketch of History. New York, 1876.

$\checkmark$ Fukuchi, G. Bakufu-Suibo-ron (Fall of the Tokugawa Shogunate). Tokyo, I8go.

× Gaiko-Shiko (A Digest of Forcign Intercourse of Japan). Compiled by the Department of Foreign Affairs in 1885.

Giddings, F. H. The Principles of Sociology. New York, 1899.

Giddings, F. H. Inductive Sociology. New York, I901.

Goodnow, F. J. Comparative Administrative Law. 2 vols. New York, I897.

Goodnow, F. J. Municipal Home Rule. Now York, 1897.

Griffis, W. E. The Mikado's Empire. New York, 1876.

Griffis, W. E. Townsend Harris, First American Envoy in Japan. Boston, 1896.

Griffis, W. E. Corea, the Hermit Nation. London, 1882.

Hall, W. A. A Treatise on International Law. 4th ed. Oxford, 1895.

Hall, W. A. A Treatise on the Foreign Powers and Jurisdiction of the British Crown. Oxford, 1894.

Hamilton, A. Korea. New York, 1904.

Harisse, H. The Diplomatic History of America (I452-1494). London, 1897.

Hart, A. B. The Foundations of American Foreign Policy. New York, Ig0I.

Hassall, A. The Balance of Power (I7I5-I789). New York, 1898.

Heffter, A. W. Völkerrecht. 3d ed. Berlin, 1855.

Heine, W. Japan. Beiträge zur Kenntniss des Landes und sciner Bewohner. Dresden, 1880.

Henderson, J. B. American Diplomatic Questions. New York, 1901.

Hildreth, R. Japan as it Was and Is. Boston, 1855.

Hobson, J. A. Imperialism. New York, 1902.

Holls, F. W. The Peace Conference at the Hague. New York, 1900.

Hosie, A. Manchuria. London, Igor.

Holland, T. E. Studies in International Law. Oxford, 1898.

Holland, T. E. The Elements of Jurisprudence. Oxford, 1900.

Hozumi, N. Ancestor-Worship and Japanese Law. Tokio, 1901.

Hozumi, N. The New Japanese Civil Code and the Study of Comparative Jurisdiction. St. Louis, 1904.

Hozumi, Y. Kenpo-Tai (Outlines of the Constitutional Law of Japan). Ed. of Igor. Tokyo.

Ingram, J. K. History of Political Economy. New York, 1888.

Ito, H. (Marquis). Teikoku-Kenpo-Kaigi (Interpretation of the Imperial Constitution). Tokyo, 1900.

Johnson, A. H. Europe in the Sixtcenth Century (1494-1598). New York, 1897.

Kaikoku-kigen (Origin of the Opening of the Country). Compiled by the Imperial Household in 1893 . 3 vols. 
Kampher, E. The History of Japan. London, 1727.

Kojiki (Ancient Chronicles of Japan). Composed in 712 A. D. Translated by B. H. Chamberlain.

Krausse, A. Russia in Asia. New York, 1899.

Laband, P. Das Staatsrecht des deutschen Reichs. Ed. of 1902. Leipzig, 1902.

Lawrence, T. Essay on Some Disputed Questions in Modern International Law. London, 1885 .

Lawrence, T. International Law. London, 1898.

Lawrence, T. War and Neutrality in the Far East. London, 1904.

Leroy-Beaulieu, P. The Awakening of the East. New York, I900.

Liszt, F. v. Das Völkerrecht, systematisch dargestellt. Berlin, 1902.

Mailla, J. M. Histoire générale de la Chine. I3 vols. Paris, 1777-1785.

Major, R. H. Prince Henry the Navigator. London, 1868.

Marshall, A. Principles of Economics. London, 1898.

Martens, F. Das Consularwesen und die Consularjurisdiction in Orient. Berlin, 1874 .

Martens, F. Völkerrecht. Berlin, 1883.

Meyer, G. Deutsches Staatsrecht. Ed. of 1878. Leipzig, 18 8 .

Moore, J. B. A Treatise on Extradition. 2 vols. Boston, 1891.

Moore, J. B. History and Digest of International Arbitrations. 6 vols. Washington, 1898.

Murray, D. The Story of Japan. New York, 1894.

Nacher. O. Die Beziehungen der niederländischen ostindischen Kompagme $э$ Japan. Leipzig, 1897.

Nakamura, S. Shinjoyakuron (Essay on the Revised Treaties). Tokyo, 1900.

Nihongi (another ancient chronicle of Japan). Composed in 720 A. D. Translated by W. G. Aston. London, 1896 .

Nitobe, O. I. The Intercourse between the United States and Japan. Baltimore, I891.

Nys, E. Les Origines du droit international. Bruxelles, 1894.

Ogawa, H. Meiji-Gaiko-Yoroku (Diplomacy of the Meiji Era). Tokyo, I902.

Phillips, W. A. Modern Europe (1815-1899). London, 1902.

Piggott, F. T. Consular Jurisdiction and Residence in Oriental Countries. London, 1892.

Raynal, G. T. F. A Philosophical and Political History of the Settlements and Trade of the Europeans in the East and West Indies. 6 vols. Edinburgh, 1804 .

Reinsch, P. S. World Politics. New York, 1902.

Rivier, A. Principes de droit des gens. 2 vols. Paris, 1896.

Rockhill, W. W. Treaties and Conventions zeith or concerning China and Korea (1894-1904). Washington, 1904. 
Roscher, W. Political Economy. New York, 1878.

Satow, E. Translation of Kinse-Shiriaku. (A history of Japan, 18531869.) Yokohama, 1876.

Satow, E. The Voyage of Captain John Saris to Japan, 1613. London, 1900.

Savigny, F. C. Private International Law. Edinburgh, 1869.

Schmoller, G. The Mercantile System.

Schoenhof, J. The Economy of High Wages. New York, 1892.

Seager, H. R. Introduction to Economics. New York, 1904.

Seeley, J. R. The Growth of British Policy. 2 vols. Cambridge, 1895.

Seligman, E. R. A. The Economic Interpretation of History. New York, 1902.

Senga, T. Gestaltung und Kritik der heutigen Konsulargerichtsbarkeit in Japan. Berlin, 1897.

Siebold, A. V. Japan's Accession to the Comity of Nations. London, 1901.

Statesman's Year Book.

Suganuma, T. Dainihon-Shogyo-Shi (Commercial History of Great Japan). Tokyo, 1892.

Takahashi, S. Cases on International Law during the China-Japanese War. Cambridge, 1899.

Takekoshi, Y. Japanese History of 2,500 Years. Tokyo, 1897.

Tarring, C. J. British Consular Jurisdiction in the East. London, 1887.

Vladimer. The China-Japan War. London, 1896.

Warden, D. B. The Origin, Nature, Progress and Influence of Consular Establishment. Paris, 1813.

Walker, T. A. The Science of International Law. Cambridge, 1893.

Walker, T. A. History of the Law of Nations. Cambridge, 1899.

Watanabe, S. Toho-Kankei (Relations of the Oriental States). Tokyo, 1894 .

Westlake, J. Chapters on the Principles of International Law. Cambridge, 1894 .

Wharton, F. A Digest of International Law of the United States. Washington, 1886.

Wheaton, H. Elements of International Law. Philadelphia, 1846.

Wheaton, H. History of the Law of Nations. New York, 1845.

Yule, H. The Book of Sir Marco Polo. London, 1875.

Zorn, A. Völkerrecht. 2d ed. Leipzig, 1903.

\section{Official Documents}

A Collection of all Treaties between Great Britain and other Powers (1688-1772).

British and Foreign State Papers. 
British Parliamentary Papers (Blue Books).

Das Staatsarchiv (State Papers of Germany).

Diplomatic Correspondence of the United States.

Executive and Legislative Documents of the United States.

Forcign Relations of the United States.

Hertslet, The Map of Europe by Treaties.

Horei-Zensho (Periodical Collection of the Japanese Law, Ordinances and Decrees).

Kwampo (Official Gazette of Japan).

Martens. Recueil de traités.

Treaties and Conventions between the Empire of Japan and other Pozvers. Vols. for I884, 1886 and I899. Tokyo.

Treaties and Conventions concluded between the United States of Amer$i c a$ and other Powers. Vols. for 1873,1889 and 1900 . Washington.

Forum. New York.

Periodicals

Gaiko-Jiho (Revue Diplomatique). Tokyo.

Harper's Monthly Magazine. New York.

Japan Weekly Mail. Yokohama.

Journal of the Society of Comparative Legislation. London.

Korean Review. Seoul.

London Times (daily and weekly).

New York Herald.

New York Times.

North American Review.

Political Science Quarterly. Columbia University.

Report of Bar Association. New York.

Revue de droit international. Paris.

The World's Work. New York.

The Far East (1896-1898). Tokyo.

The Independent. New York.

Taiyo (The Sun). Tokyo.

Toyokcizaizashi (The Magazine of Oriental Economy). Tokyo.

Transactions of the Asiatic Society of Japan. Yokohama. 

VOLUME XVI, 1E02-1903. 547 pp. Price, $\$ 3.00$.

1. The Past and Present of Commerce in Japan.

By Yetaro Kinosita, Ph.D. Price, \$ir.5o

2. The Enuployment of Women in the Clothing Trade.

By MABel Hurd Willet, Ph.D. Price, $\$ \mathbf{I} .50$

3. The Centralization of Administration in Ohio.

By Samuel P. Orth, Ph.D. Price, $\$$ r.50.

VOLUME XVII, 1903. 635 pp. Price, $\$ 3.50$.

1. *entralizing Tendencies in the Administration of Indiana.

By William A. Rawles, Ph.D. P'rice, \$2 50.

2. Principles of Justice in Taxation.

By Stephen F. Weston, Ph.D. Price, $\$ 2.00$

VOLUME XVIII, 1903. 753 pp. Price, $\$ 4.00$.

1. The Administration of Iowa.

2. 'Turgot and the Six Edicts.

3. Hanover and Prussia, 1795-1803.

By Harold Martin Bowman, Ph.D. Price, \$r.50.

By Robert P. Sherherd, Ph.D. Price, $\$$ I.50

By Guy Stanton Ford, Ph. D. Price, \$2.00.

VOLUME XIX, 1903-1905. 588 pp. Price, \$3.50.

1. Josiah Tucker, Economist. By Walter Ernest Clark, Ph.D. Price, \$1.50.

2. History and Criticism of the Labor Theory of Value in English Political Economy. By Albert C. Whitaker, Ph.D. Price, $\$ 1.50$.

3. Trade Unions and the Law in New York.

By Grozge Gorham Groat, Ph.D. Price, \$1.00.

VOLUME XX, 1904. $514 \mathrm{pp}$. Price, $\$ 3.00$.

1. The Office of the Justice of the Peace in England.

By Charles Austin Beard, Ph. D. Price, \$r.50.

2. A History of Military Government in Newly Acquired Torritory of the United States.

By David Y. Thomas, Ph.D. Price, \$2.00.

VOLUIME XXI, 1904. 746 p. Price, $\$ 4.00$.

1. *Treaties, their Making and Inforcement.

By Samuel B. Crandall, Ph.D. Price, \$1.50.

2. The Sociology of a New York City biock.

By Thomas Jesse Jones, Ph.D. Price, \$r.oo.

3. Pre-Malthusian Doctrines of Population.

By Charles E. Stangeland, Ph.D. Price, \$2.50.

VOLUNE XXII, 1905. 520 pp. Price, $\$ 3.00$.

The Historical Development of the Poor Law of Connecticut.

By Euward W. Capen, Ph.D.

VOLUMI XXIII, 1905. 594 pp. Price, $\$ 3.50$.

1. The Economics of Land Tenure in Gcorgia.

By Enoch Marvin Banks, Ph.D. Price, \$r.oo

2. Mistake in Contract. A Study in Comparative Jurisprudence.

3. Combination in the Mining Indust $3 \cdot y$.

Ey Edwin C. McKrag, Ph.D. Price, \$1.>0.

By Henry R. Mussey, Ph.D. Price, \$1.00.

4. The English Craft Gilds and the Government.

By Stella Kramer, Ph.D. Price, $\$ \mathbf{r} .00$.

\section{VOLUME XXIV, 1805. 521 pp. Price, $\$ 3.00$.}

1. The Place of Magic in the Intellectual History of Europe.

By Lynn Thorndike, Ph.D. Price, 75 cents.

2. The Ecciesiastical Edicts of the Thcodosian Code.

Py WILliam K. Boyd, Ph.D. Price, 75 cents.

3. *The International Position of Japan as a Great Power.

By Sziji G. Hishida, Ph.D. Price, $\$ 2.00$ 
1. *Munleipal Control of Public Utilities.

By Oscar Lewis Pond, Ph.D. Price, $\$$ r.00.

2. The Budget in the American Commonwealths.

By Eugrne E. Aggre, Ph.D. Price, \$ 50.

3. The Finances of Cleveland. By Charles C. Williamson, Ph.D. Price, $\$ 2.00$.

\section{VOLUME XXVI, 1307. 559 pp. Price, \$3.50.}

1. Trade and Currency in Early Oregon.

2. Luthers's Table Tell. By Preserved Smitr, Ph.D. Price, \$r.oo.

3. The Tobacco Industry in the United States.

By Meyer Jacobstein, Ph.D. Price, \$1.50.

4. Soclal Democracy and Population.

By Alvan A. Tenney, Ph.D. Price, 75 cents.

VOLUMI XIVIX, 1907. 578 m. Price, $\$ 3.50$.

1. The Economic Pollcy o1 Robert Welpole.

Ey Nukris A. Brisco, Ph.D. Price, \$1.50.

2. The United States Steel Corporation.

By Abraham Brgalund, Ph.D. Price, $\$ 1.50$.

3. 'The Taxation of Corporations in Massachusetts.

By Harry G. Friedman, A.B. Price, \$1.50.

VOLUME XXVIIT, 1907.

1. DeWitt Clinton and the Origin of the Spolls System in New Xork. By Howard Lie McBain, Ph.D. Price, \$r.50.

2. The Sociallzation of Ownership.

By JOSBPa HARDING UNDERWOOd. (In press.)

3. The Development of the Legislature of Colonial Virginia.

By E. I. Miller. (In press.)

VOLUME XXIX, 1907-08.

1. The Enforcement of the Statute of Laborers.

By Brrtha haven Putnam. (In press.)

The price for each volume is for the set of monographs in paper. Each volume, as well as the separate monographs marked ${ }^{*}$, can be supplied in eloth-bound copies, for 50c. additional.

The set of twenty-seven volumes (except that Vol. II can be supplied only in unbound nos. 2 and 3 ) is offered bound for $\$ 86$.

Volumes I, III and IV can now be supplied only in connection with complete sets.

For further intormation, apply to

Prof. EDWIN R. A. SELIGMAN, Columbla University, or to the MACMILLAN COMPANY, New York.

London: P. S. KING \& SON, Orchard House, Westminster. 



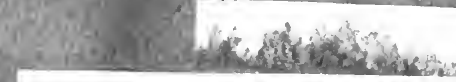

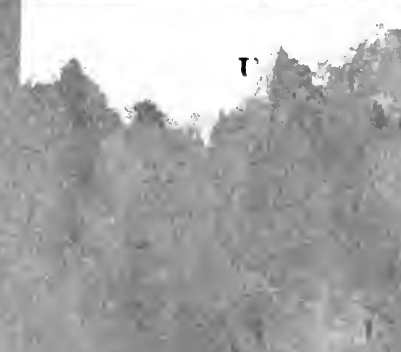

14 DAY USE

RETURN TO DESK FROM WHICH BORROWED

\section{LOAN DEPT.}

This book is due on the last date stamped below, or on the date to which renewed.

Renewed books are subject to immediate recall.

REC'D LD SEP 919698
5 SCT'63RV
REC'D LPRC 12196906

SEP 26 O3-8 AM

REC'D LD JAN 7-70-11 AM 

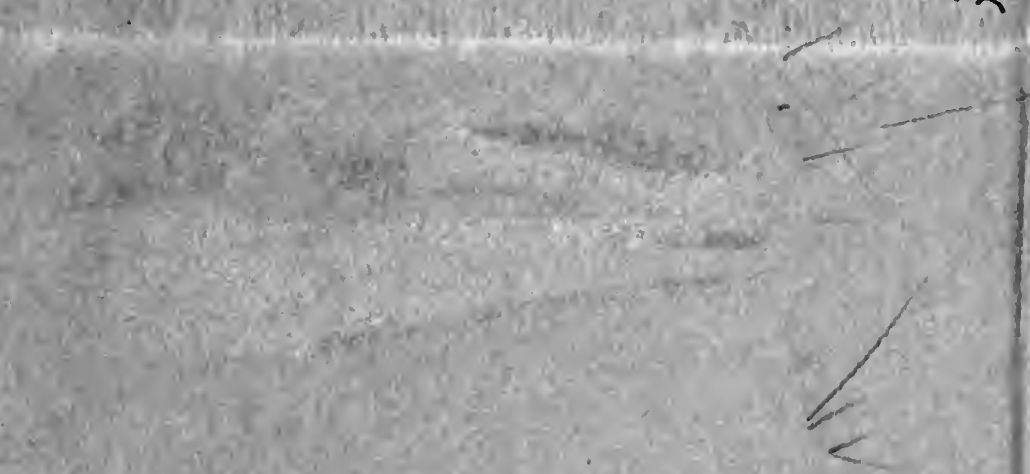

\section{4}

UNIVERSITY OF CALIFORNIA LIBRARY

W'

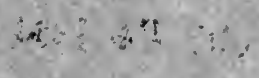

$\left\{x^{2}+1\right\}:+9$ 
ititis:

$\because$

$\therefore i=i_{7}=t \ldots$

$1=2+4+1+2$

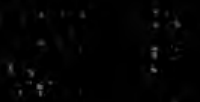

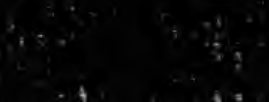

$+4$

$+2$

t..

$x+2 x^{*}-4$

3

$i=i$

$\therefore$

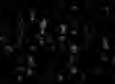

ath

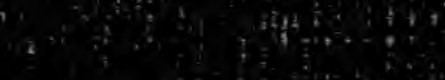

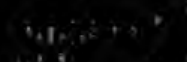

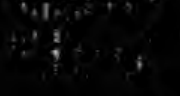

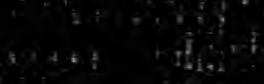

$b^{27}$

.

if $=$ is

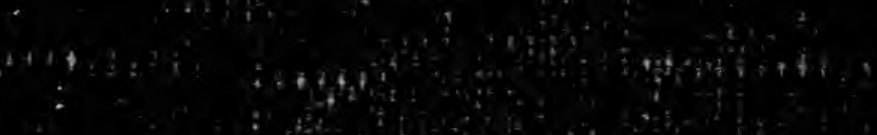

\section{: 5}

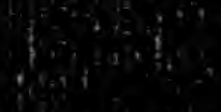

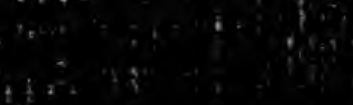

4

,

it

25

i) 